Prepared in cooperation with Eureka County, Nevada

\title{
Budgets and Chemical Characterization of Ground water for the Diamond Valley Flow System, Central Nevada, 2011-12
}
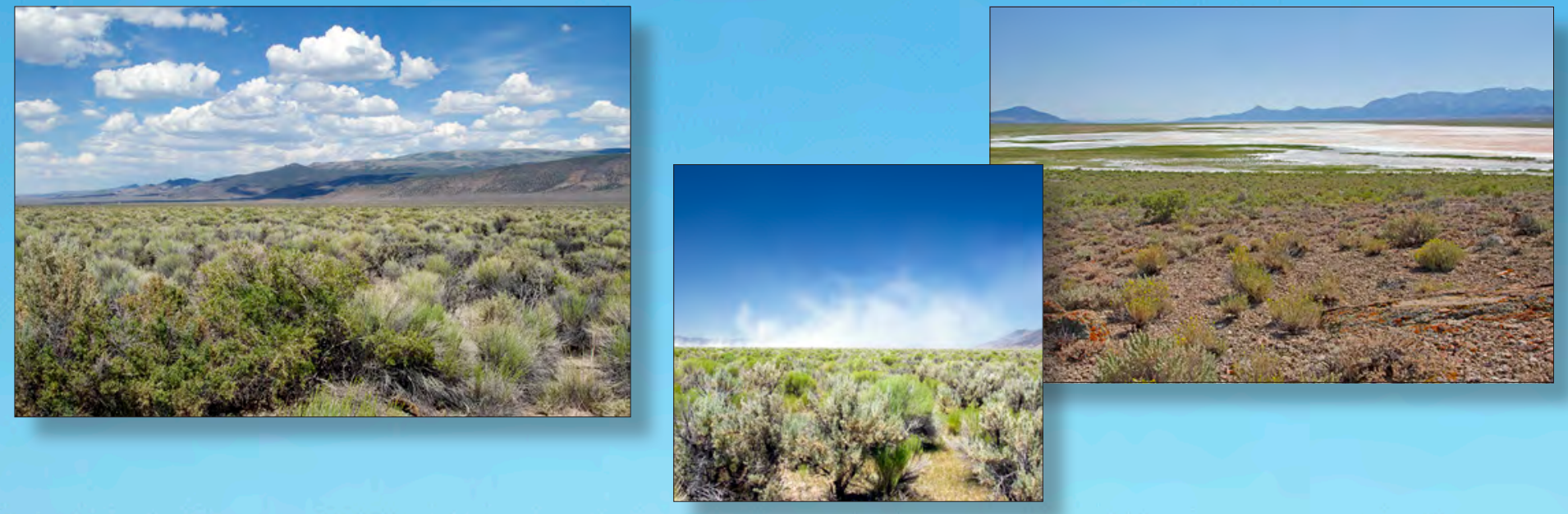

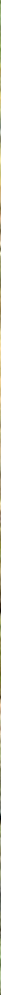




\section{Cover photographs}

\section{Upper left}

Southern Monitor Valley looking northwest toward the Toquima Range. Valley floor vegetation is composed primarily of phreatophytic greasewood (Sarcobatus vermiculatus) and rabbitbrush (Chrysothamnus spp.).

\section{Upper right}

Monitor Valley looking southwest over the Monitor Valley playa toward the Toquima Range. Low-growing vegetation on the playa margins is saltgrass (Distichlis spicata).

Bottom

Diamond Valley looking northwest toward a dust plume from the Diamond Valley playa. Foreground vegetation is composed primarily of sagebrush (Artemisia tridentata) and rabbitbrush (Chrysothamnus spp.)

\section{Background}

Antelope valley looking north toward Lone Mountain (central, foreground), Roberts Mountains (left).

All photographs by Susan G. Buto 


\section{Budgets and Chemical Characterization of Groundwater for the Diamond Valley Flow System, Central Nevada, 2011-12}

By David L. Berger, C. Justin Mayers, C. Amanda Garcia, Susan G. Buto, and Jena M. Huntington

Prepared in cooperation with Eureka County, Nevada

Scientific Investigations Report 2016-5055 


\title{
U.S. Department of the Interior SALLY JEWELL, Secretary
}

\section{U.S. Geological Survey Suzette M. Kimball, Director}

\author{
U.S. Geological Survey, Reston, Virginia: 2016
}

For more information on the USGS - the Federal source for science about the Earth, its natural and living resources, natural hazards, and the environment—visit http://Www.usgs.gov or call 1-888-ASK-USGS.

For an overview of USGS information products, including maps, imagery, and publications, visit http://store.usgs.gov.

Any use of trade, firm, or product names is for descriptive purposes only and does not imply endorsement by the U.S. Government.

Although this information product, for the most part, is in the public domain, it also may contain copyrighted materials as noted in the text. Permission to reproduce copyrighted items must be secured from the copyright owner.

Suggested citation:

Berger, D.L., Mayers, C.J., Garcia, C.A., Buto, S.G., and Huntington, J.M., 2016, Budgets and chemical characterization of groundwater for the Diamond Valley flow system, central Nevada, 2011-12: U.S. Geological Survey Scientific Investigations Report 2016-5055, 83 p., http://dx.doi.org/10.3133/sir20165055.

ISSN 2328-0328 (online) 


\section{Acknowledgments}

The authors thank the private landowners who allowed access to their wells for water-level measurements and the collection of water-chemistry data. The authors gratefully thank Eureka, Lander, and Nye Counties; the Nevada Department of Water Resources; and General Moly, Inc. Particular thanks go to the Eureka County Commissioners and staff for their help, patience, and knowledge. 


\section{Contents}

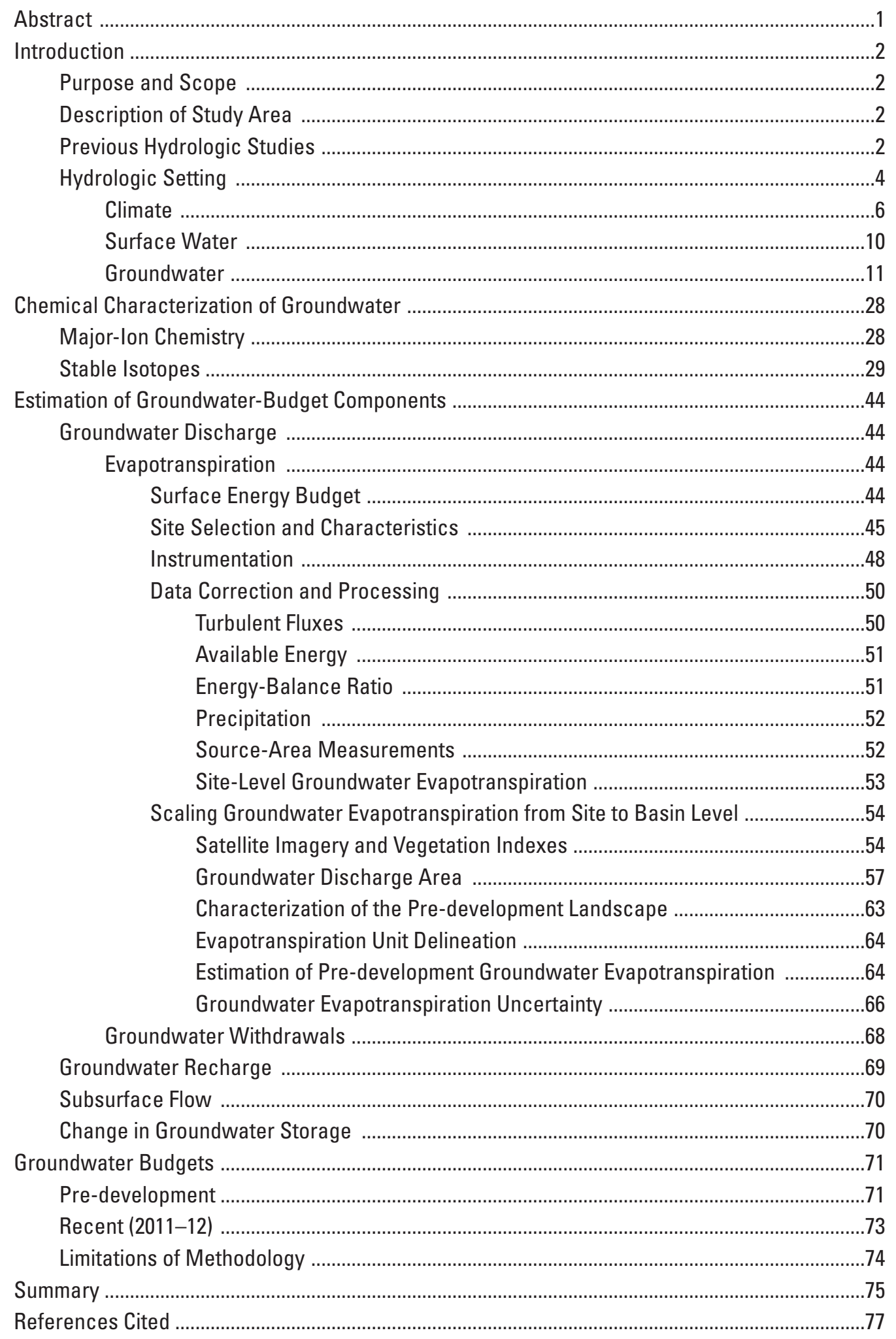


Appendix 1: Description of Spatial Datasets. . .81

Water-Level Altitude Contours for the Diamond Valley Flow System, Central Nevada, 2012 . .81

Irrigated Agricultural Lands and Associated Land Disturbance in the Diamond Valley Flow System, Central Nevada, 2011 . .81

Groundwater Discharge Area for the Diamond Valley Flow System, Central Nevada ...........81

Summer Mean Enhanced Vegetation Index for the Diamond Valley Flow System Groundwater Discharge Area, 2010 .81

Evapotranspiration Units for the Diamond Valley Flow System, Central Nevada, 2010 .........81

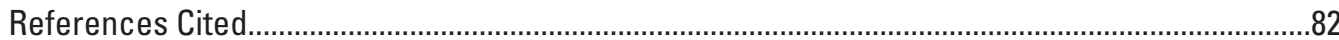

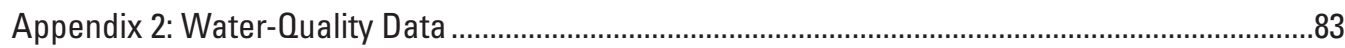

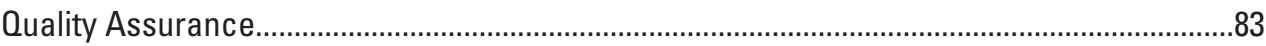

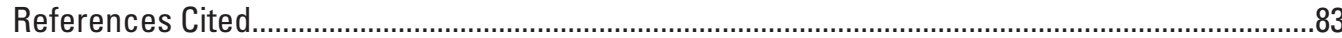

\section{Plate}

Groundwater Levels in Basin-Fill Deposits, Groundwater Discharge Areas, and Agricultural Areas of the Diamond Valley Flow System, Central Nevada. The plate can be found at $h t t p: / / d x$. doi.org/10.3133/sir20165055.

\section{Figures}

1. Map showing hydrographic areas and selected geographic features in the Diamond Valley flow system, central Nevada

2. Map showing atmospheric sites, surface-water sites, and spring sites in the Diamond Valley flow system, central Nevada

3. Graphs showing comparison between average annual precipitation for four longterm precipitation stations, Diamond Valley flow system, central Nevada, and $A$, station altitude, and $B$, PRISM derived precipitation

4. Graph showing annual water year precipitation and cumulative departure from normal, Eureka, central Nevada

5. Maps showing groundwater sites in $A$, the Diamond Valley flow system, central Nevada; $B$, parts of northern Monitor and Kobeh Valleys; $C$, parts of Kobeh and Diamond Valleys

6. Hydrographs showing water-level change in selected wells in the Diamond Valley flow system, central Nevada, 1950-2012

7. Graph showing miscellaneous spring-discharge measurements for Shipley Hot Springs and Taft-Thompson Spring, 1965-2012, Diamond Valley flow system, central Nevada

8. Map showing geology, groundwater-level contours, and sites sampled for groundwater chemistry and chemical typing, Diamond Valley flow system and adjacent basins, central Nevada, 1954-2012

9. Piper plots characterizing the chemical type of groundwater in the Diamond Valley flow system, central Nevada

10. Graph showing relation between oxygen-18 and deuterium for precipitation, groundwater, and spring water samples, Diamond Valley flow system and adjacent valleys, central Nevada 
11. Photographs showing evapotranspiration sites, Kobeh Valley, central Nevada photographed $A$, laterally to show instrumentation and vegetation at sites 1-4, and, $B$, aerially from a location approximately 328 feet west of sites $1-3$ to show vegetation distribution in an approximately 28 -foot square footprint

12. Graphs showing continuously measured precipitation and near-surface volumetric soil-water content at evapotranspiration sites, 0ctober 2010 through September 2012, central Nevada

13. Hydrographs from wells collocated with evapotranspiration sites, Kobeh Valley, central Nevada; sites 130, 150, 142, and 143 were collocated with sites 1-4, respectively

14. Graphs showing source-area contributions to turbulent fluxes with distance from site 2, Kobeh Valley, Nevada: $A$, cumulative and $B$, relative measured 53

15. Graphs showing daily energy-balance corrected evapotranspiration and precipitation at four evapotranspiration (ET) sites and the computed potential ET at site 4, October 2010 through September 2012, Kobeh Valley, central Nevada

16. Map showing groundwater discharge area, evapotranspiration units, and variation in the scaled summer-mean 2010 Enhanced Vegetation Index, Diamond Valley flow System, central Nevada

17. Maps showing previous groundwater discharge-area delineations compared with 2011 delineations, Diamond Valley flow system, central Nevada

18. Graphs showing relations between 2011-12 groundwater evapotranspiration and the scaled Enhanced Vegetation Index for shrubland and grassland evapotranspiration units for the summer-mean 2010 image, Kobeh Valley, central Nevada

19. Graph showing mean annual basin-scale groundwater discharge from and total area of shrubland, grassland, and playa evapotranspiration units, Diamond Valley flow System, central Nevada

20. Graphs showing basin-specific comparisons of average annual PRISM precipitation for 1981-2010 in vegetated ET units, area-weighted average groundwater evapotranspiration (ET) for shrubland ET units, and average scaled enhanced vegetation index for shrubland ET units for the 2010 summer-mean image, Diamond Valley flow system, central Nevada

21. Graph showing estimated net groundwater withdrawals from pumping, pre-development natural discharge, and irrigated-acreage for 1950-2012 in Diamond Valley, central Nevada

\section{Tables}

1. Location and general description of atmospheric measurement sites, Diamond Valley flow system, central Nevada

2. Measured precipitation data at four evapotranspiration sites in Kobeh Valley, seven climate stations near the Diamond Valley flow system, and Parameter-elevation Regressions on Independent Slopes Model (PRISM) estimates, central Nevada

3. Location and general information of surface-water measurement sites, Diamond Valley flow system, central Nevada

4. Location and general information of spring-measurement sites, Diamond Valley flow system, central Nevada

5. Location and general information for groundwater-measurement sites, Diamond Valley flow system, central Nevada

6. Selected water-chemistry data, Diamond Valley flow system and adjacent basins, central Nevada, 1954-2013 
7. Specific conductance, sodium, chloride, and total dissolved-solids concentrations from selected sites along northerly flowpath in southern Diamond Valley, central Nevada, 1965-67

8. Vegetation type, canopy cover, and height measured at four evapotranspiration sites, May 2012, Kobeh Valley, Nevada

9. Above-ground sensor heights, in feet, at four evapotranspiration stations, Kobeh Valley, Nevada 50

10. Energy-balance ratio, slope and coefficient of determination from ordinary least squares regressions comparing turbulent flux and available energy measurements, and percent good half-hour and daily data at four evapotranspiration sites, Kobeh Valley, Nevada

11. Annual mean wind speed measured at two heights, liquid fraction of total precipitation, and measured and corrected precipitation at four evapotranspiration sites, Kobeh Valley, Nevada, 2011 and 2012

12. Measured annual precipitation, energy-balance evapotranspiration, soil-water storage change, groundwater evapotranspiration and associated uncertainties at four evapotranspiration sites, Kobeh Valley, central Nevada, 2011-12

13. Landsat 5 Thematic Mapper scenes evaluated for use in basin-scale estimation of groundwater evapotranspiration, Diamond Valley flow system, central Nevada

14. Coefficients of determination describing relations between vegetation indices and site-scale groundwater evapotranspiration, Kobeh Valley, Nevada

15. Groundwater discharge areas by vegetation type and groundwater-evapotranspiration rates from previous investigations and this study, Diamond Valley flow system, central Nevada

16. Mean annual basin-scale groundwater evapotranspiration (ET) and ET unit area, Diamond Valley flow system, central Nevada

17. Estimated outflow components of the annual groundwater budget, in acre-feet, for pre-development and recent conditions, Diamond Valley flow system, central Nevada

18. Estimated inflow components for annual groundwater budget, in acre-feet, representing pre-development and recent conditions, Diamond Valley flow system, central Nevada

19. Average annual groundwater budget, in acre-feet, representing current conditions, Diamond Valley flow system, central Nevada 


\section{Conversion Factors}

Inch/Pound to International System of Units

\begin{tabular}{|c|c|c|}
\hline Multiply & By & To obtain \\
\hline \multicolumn{3}{|c|}{ Length } \\
\hline inch (in.) & 2.54 & centimeter $(\mathrm{cm})$ \\
\hline inch (in.) & 25.4 & millimeter $(\mathrm{mm})$ \\
\hline foot $(\mathrm{ft})$ & 0.3048 & meter $(\mathrm{m})$ \\
\hline mile (mi) & 1.609 & kilometer $(\mathrm{km})$ \\
\hline \multicolumn{3}{|c|}{ Area } \\
\hline acre & 4,047 & square meter $\left(\mathrm{m}^{2}\right)$ \\
\hline square foot $\left(\mathrm{ft}^{2}\right)$ & 929.0 & square centimeter $\left(\mathrm{cm}^{2}\right)$ \\
\hline square foot $\left(\mathrm{ft}^{2}\right)$ & 0.09290 & square meter $\left(\mathrm{m}^{2}\right)$ \\
\hline square mile $\left(\mathrm{mi}^{2}\right)$ & 2.590 & square kilometer $\left(\mathrm{km}^{2}\right)$ \\
\hline \multicolumn{3}{|c|}{ Volume } \\
\hline cubic inch $\left(\right.$ in $\left.^{3}\right)$ & 16.39 & cubic centimeter $\left(\mathrm{cm}^{3}\right)$ \\
\hline cubic inch $\left(\mathrm{in}^{3}\right)$ & 0.01639 & $\operatorname{liter}(\mathrm{L})$ \\
\hline acre-foot (acre-ft) & 1,233 & cubic meter $\left(\mathrm{m}^{3}\right)$ \\
\hline \multicolumn{3}{|c|}{ Flow rate } \\
\hline acre-foot per year (acre-ft/yr) & 1,233 & cubic meter per year $\left(\mathrm{m}^{3} / \mathrm{yr}\right)$ \\
\hline foot per year $(\mathrm{ft} / \mathrm{yr})$ & 0.3048 & meter per year $(\mathrm{m} / \mathrm{yr})$ \\
\hline cubic foot per second $\left(\mathrm{ft}^{3} / \mathrm{s}\right)$ & 0.02832 & cubic meter per second $\left(\mathrm{m}^{3} / \mathrm{s}\right)$ \\
\hline \multicolumn{3}{|c|}{ Hydraulic gradient } \\
\hline foot per mile (ft/mi) & 0.1894 & meter per kilometer $(\mathrm{m} / \mathrm{km})$ \\
\hline \multicolumn{3}{|c|}{ Transmissivity* } \\
\hline foot squared per day $\left(\mathrm{ft}^{2} / \mathrm{d}\right)$ & 0.09290 & meter squared per day $\left(\mathrm{m}^{2} / \mathrm{d}\right)$ \\
\hline
\end{tabular}

Temperature in degrees Celsius $\left({ }^{\circ} \mathrm{C}\right)$ may be converted to degrees Fahrenheit $\left({ }^{\circ} \mathrm{F}\right)$ as ${ }^{\circ} \mathrm{F}=(1.8 \times$ $\left.{ }^{\circ} \mathrm{C}\right)+32$.

Temperature in degrees Fahrenheit $\left({ }^{\circ} \mathrm{F}\right)$ may be converted to degrees Celsius $\left({ }^{\circ} \mathrm{C}\right)$ as ${ }^{\circ} \mathrm{C}=\left({ }^{\circ} \mathrm{F}-\right.$ 32) / 1.8 .

\section{Datum}

Vertical coordinate information is referenced to the North American Vertical Datum of 1988 (NAVD 88).

Horizontal coordinate information is referenced to the North American Datum of 1983 (NAD 83).

Altitude, as used in this report, refers to distance above the vertical datum.

\section{Supplemental Information}

Transmissivity: The standard unit for transmissivity is cubic foot per day per square foot times foot of aquifer thickness ([ft $\left.\left.\mathrm{ft}^{3} \mathrm{~d}\right] / \mathrm{ft}^{2}\right) \mathrm{ft}$. In this report, the mathematically reduced form, foot squared per day $\left(\mathrm{ft}^{2} / \mathrm{d}\right)$, is used for convenience.

Specific conductance is given in microsiemens per centimeter at 25 degrees Celsius $(\mu \mathrm{S} / \mathrm{cm}$ at $\left.25^{\circ} \mathrm{C}\right)$.

Concentrations of chemical constituents in water are given in either milligrams per liter ( $\mathrm{mg} / \mathrm{L}$ ) or micrograms per liter $(\mu \mathrm{g} / \mathrm{L})$. 


\section{Abbreviations}

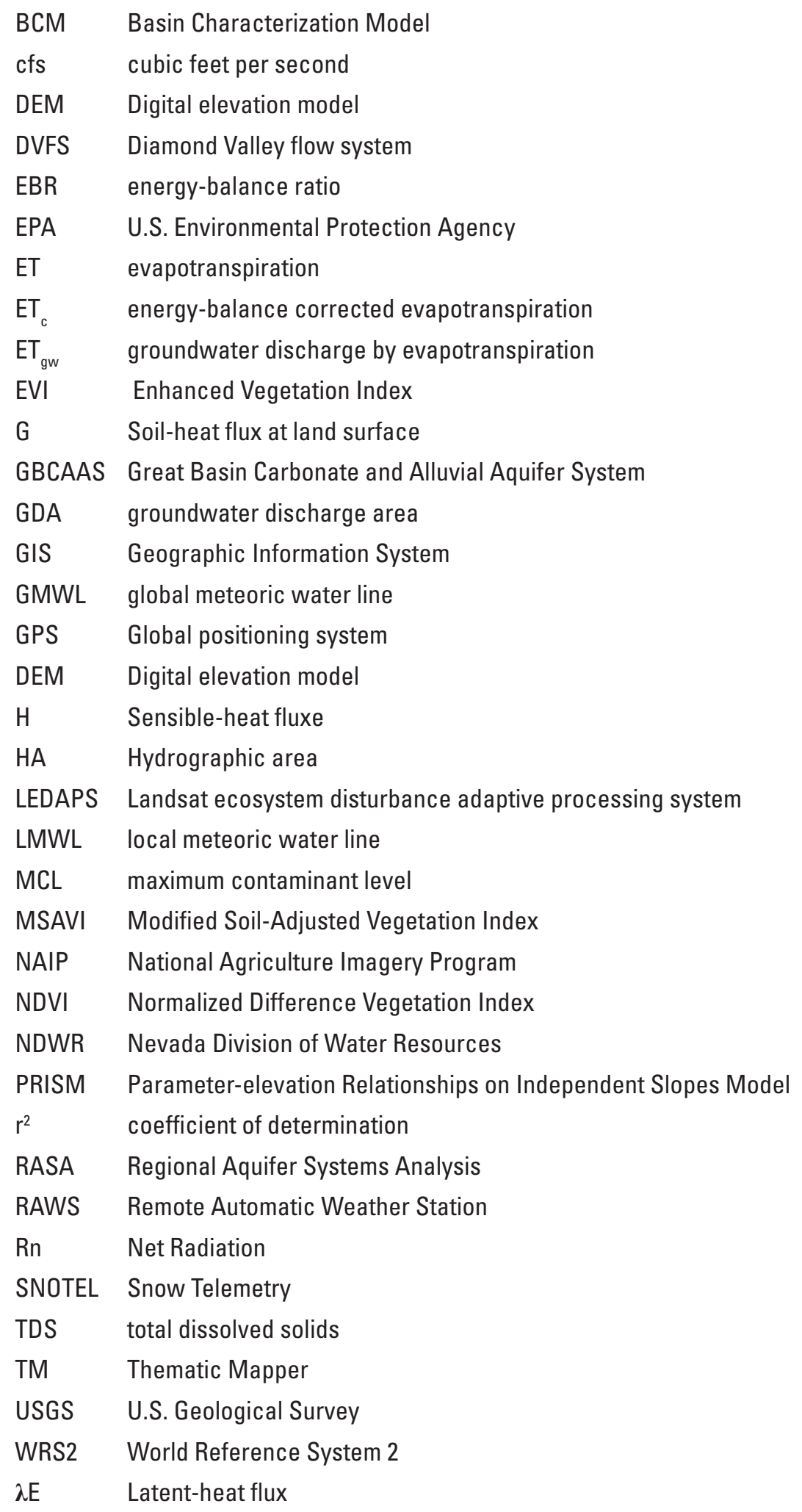




\title{
Budgets and Chemical Characterization of Groundwater for the Diamond Valley Flow System, Central Nevada, 2011-12
}

\author{
By David L. Berger, C. Justin Mayers, C. Amanda Garcia, Susan G. Buto, and Jena M. Huntington
}

\section{Abstract}

The Diamond Valley flow system consists of six hydraulically connected hydrographic areas in central Nevada. The general down-gradient order of the areas are southern and northern Monitor Valleys, Antelope Valley, Kobeh Valley, Stevens Basin, and Diamond Valley. Groundwater flow in the Diamond Valley flow system terminates at a large playa in the northern part of Diamond Valley. Concerns relating to continued water-resources development of the flow system resulted in a phased hydrologic investigation that began in 2005 by the U.S. Geological Survey in cooperation with Eureka County. This report presents the culmination of the phased investigation to increase understanding of the groundwater resources of the basin-fill aquifers in the Diamond Valley flow system through evaluations of groundwater chemistry and budgets. Groundwater chemistry was characterized using major ions and stable isotopes from groundwater and precipitation samples. Groundwater budgets accounted for all inflows, outflows, and changes in storage, and were developed for predevelopment (pre-1950) and recent (average annual 2011-12) conditions. Major budget components include groundwater discharge by evapotranspiration and groundwater withdrawals; groundwater recharge by precipitation, and interbasin flow; and storage change.

Groundwater in the basin-fill aquifer of the Diamond Valley flow system was mostly a calcium or sodium bicarbonate water type and generally within acceptable drinking-water standards. The general water type was similar among the individual hydrographic areas. Stable isotopes of oxygen-18 and deuterium from precipitation varied seasonally, such that enrichment from evaporation was greater during warmer months than cooler months. The isotopic signature of shallow groundwater was similar to cool season precipitation, indicating recharge was relatively recent (similar to recent climatic conditions) and was derived from cool season precipitation.

Site-scale groundwater evapotranspiration was estimated from eddy-covariance and micrometeorological measurements collected at four sites and ranged from 0.15 feet per year in sparse, undisturbed shrubland to 1.13 feet per year in a grassland meadow. Vegetation indices calculated from satellite imagery and field mapping were used to define three evapotranspiration units (shrubland, grassland, and playa) and to extrapolate site-scale groundwater evapotranspiration rates to basin-scale estimates. Annual pre-development groundwater evapotranspiration for individual hydrographic areas ranged from 2,900 acre-feet per year (acre-ft/yr) in northern Monitor Valley to 35,000 acre-ft/yr in Diamond Valley. Total groundwater evapotranspiration from the Diamond Valley flow system under pre-development conditions was about 70,000 acre-ft/yr.

Areas of irrigated land in the Diamond Valley flow system increased from less than 5,000 acres in the early 1960s to more than 25,000 acres in 2012 and are mostly for growing alfalfa in southern Diamond Valley. Annual (2011-12) net groundwater withdrawals for irrigation, assumed to be the volume of groundwater consumed by crops and pastureland, ranged from about 420 acre-ft/yr in Antelope Valley to 67,000 acre-ft/yr in Diamond Valley. Total net groundwater withdrawals for irrigation in the Diamond Valley flow system were about 69,000 acre-ft/yr (2011-12).

Groundwater recharge, the largest inflow component to the Diamond Valley flow system, was determined as the sum of groundwater evapotranspiration and net subsurface outflow (subsurface outflow minus subsurface inflow). Annual groundwater recharge estimates ranged from $200 \mathrm{acre}-\mathrm{ft} / \mathrm{yr}$ in Stevens Basin to 35,000 acre-ft/yr in Diamond Valley.

Subsurface flow between hydrographic basins was evaluated using estimated transmissivity, groundwater-flow sections derived from remotely sensed imagery, and hydraulic gradients determined from 2012 water-level data. Subsurface outflow ranged from 0 acre-ft/yr for Diamond Valley to 3,400 acre-ft/yr for northern Monitor Valley into western Kobeh Valley. Subsurface inflow ranged from 0 acre-ft/yr for southern Monitor Valley to 4,200 acre-ft/yr for Kobeh Valley from northern Monitor and Antelope Valleys.

The pre-development, steady state, groundwater budget for the Diamond Valley flow system was estimated at about 70,000 acre-ft/yr of inflow and outflow. During years 2011-12, inflow components of groundwater recharge from precipitation and subsurface inflow from adjacent basins totaled 70,000 acre-ft/yr for the DVFS, whereas outflow components included $64,000 \mathrm{acre}-\mathrm{ft} / \mathrm{yr}$ of groundwater evapotranspiration and 69,000 acre-ft/yr of net groundwater withdrawals, or net pumpage. Spring discharge in northern Diamond Valley declined about 6,000 acre-ft/yr between pre-development time and years 2011-12. Assuming net groundwater withdrawals minus spring flow decline is equivalent to the storage change, the 2011-12 summation of inflow and storage change was balanced with outflow at about 133,000 acre-ft/yr. 


\section{Introduction}

The Diamond Valley flow system (DVFS) consists of six basins or hydrographic areas (HAs) in central Nevada (Harrill and others 1983; fig. 1). The six basins are, in part, hydrologically connected by ephemeral streams, by groundwater flow in shallow basin-fill aquifers, and, possibly, by subsurface flow in deeper carbonate-rock aquifers. Groundwater in basin-fill aquifers moves from southern Monitor Valley to northern Monitor and then into western Kobeh Valley. Eastern Kobeh Valley also receives groundwater from Antelope Valley. A small amount of groundwater moves from eastern Kobeh Valley into southern Diamond Valley in the basin fill beneath Devils Gate. The large playa in the northern part of Diamond Valley is the terminus of the flow system. Subsurface flow from Stevens Basin into adjacent basins is unknown but assumed to be minimal.

As early as 1964, the Nevada State Engineer recognized that areas in the DVFS required additional regulation of groundwater withdrawals, particularly in the southern part of Diamond Valley and, later, the entire hydrographic areas of Diamond and Kobeh Valleys. In 1983, Diamond and Kobeh Valleys both were declared "designated" groundwater basins. In designated basins, the State Engineer is granted the authority to, among other directives, "designate preferred uses of water within the respective areas" in the interest of public welfare of the area involved (Nevada Revised Statutes, chapter 534).

Local government officials and citizens are concerned about the continuing development of water resources for irrigation and mining and about the potential for groundwater exportation to basins outside the DVFS. In 2005, the U.S. Geological Survey (USGS), in cooperation with Eureka, Lander, and Nye Counties and the Nevada Division of Water Resources (NDWR) began a three-phased study of the flow system to gain a better understanding of the groundwater resources. Phase 3 (2009-12), documented in this report, was the final phase of work designed to build on and further characterize the groundwater resources of the flow system by evaluating groundwater quality and groundwater budgets, with emphasis on groundwater evapotranspiration by phreatophytes (plants that rely on groundwater to fulfill a part of their water needs) under predevelopment conditions.

\section{Purpose and Scope}

This report presents the culmination of results from the multi-phased investigation of the groundwater resources in the DVFS. The report characterizes groundwater chemistry of the basin-fill aquifers in terms of major-ion water types, drinking-water standards, and groundwater recharge and mixing. Annual groundwater budgets for each hydrographic area, representing recent conditions (2011-12), are presented and compared with revised pre-development (pre-1950) groundwater budgets. Components of the groundwater budgets include groundwater recharge from precipitation; subsurface flow between basins; and groundwater discharge by (1) evapotranspiration from areas composed of phreatophytic vegetation, (2) evaporation from playas, and (3) estimated net groundwater withdrawals for irrigation. Groundwater evapotranspiration from phreatophyte areas was measured in Kobeh Valley, and adjusted values were applied to other DVFS basins. A groundwater budget for the complete DVFS also is presented and includes a summation of all inflow and outflow components and an estimate of storage loss resulting from groundwater withdrawals.

\section{Description of Study Area}

The DVFS (fig. 1) covers about 3,100 square miles $\left(\mathrm{mi}^{2}\right.$, or 1,984,000 acres) in central Nevada and includes six basins or HAs. The flow system was defined initially by Harrill and others (1983) as part of a regional aquifer-systems analysis in the Great Basin of Nevada, Utah, and adjacent states. A large playa (nearly 43,000 acres) in the northern part of Diamond Valley is the terminus of the DVFS. Another playa, covering about 1,400 acres, is in the northern part of southern Monitor Valley. Most groundwater development in the DVFS has been in the southern part of Diamond Valley and has resulted in nearly 100 feet (ft) of water-level decline since 1962. A more detailed description of the study area can be found in Tumbusch and Plume (2006).

The DVFS is mostly in Eureka County; however, small portions lie in northern Nye, eastern Lander, and southern Elko Counties (fig. 1). The city of Eureka (population of about 610 ) is an unincorporated community and the county seat of Eureka County (population of about 2,000; U.S. Census Bureau, 2015a, 2015b). U.S. Highway 50 traverses Kobeh Valley and southern Diamond Valley, connecting the towns of Austin and Eureka. Nevada State Route 278 runs from 3 miles west of Eureka north along the western side of southern Diamond Valley (fig. 1).

\section{Previous Hydrologic Studies}

The earliest water-resource appraisals in the study area were commissioned by the Nevada State Legislature in 1960 and published in two reconnaissance-series reports. Eakin (1962) focused on Diamond Valley and Rush and Everett (1964) focused on southern and northern Monitor Valleys, Antelope Valley, Kobeh Valley, and Stevens Basin. The reconnaissance studies provided available climatic data and general conditions of the hydrologic systems, including geology and groundwater quality in terms of suitability for agricultural use. Additionally, both studies provided estimates of annual groundwater recharge and discharge under nearly natural conditions. Natural groundwater recharge and discharge assumes pre-development, steady-state conditions, with little or no anthropogenic effects. Although water-chemistry data for groundwater collected from wells and springs were limited at the time of the reconnaissance studies, groundwater was considered suitable for irrigation in most areas. The reconnaissance studies relied on the precipitation map developed by 


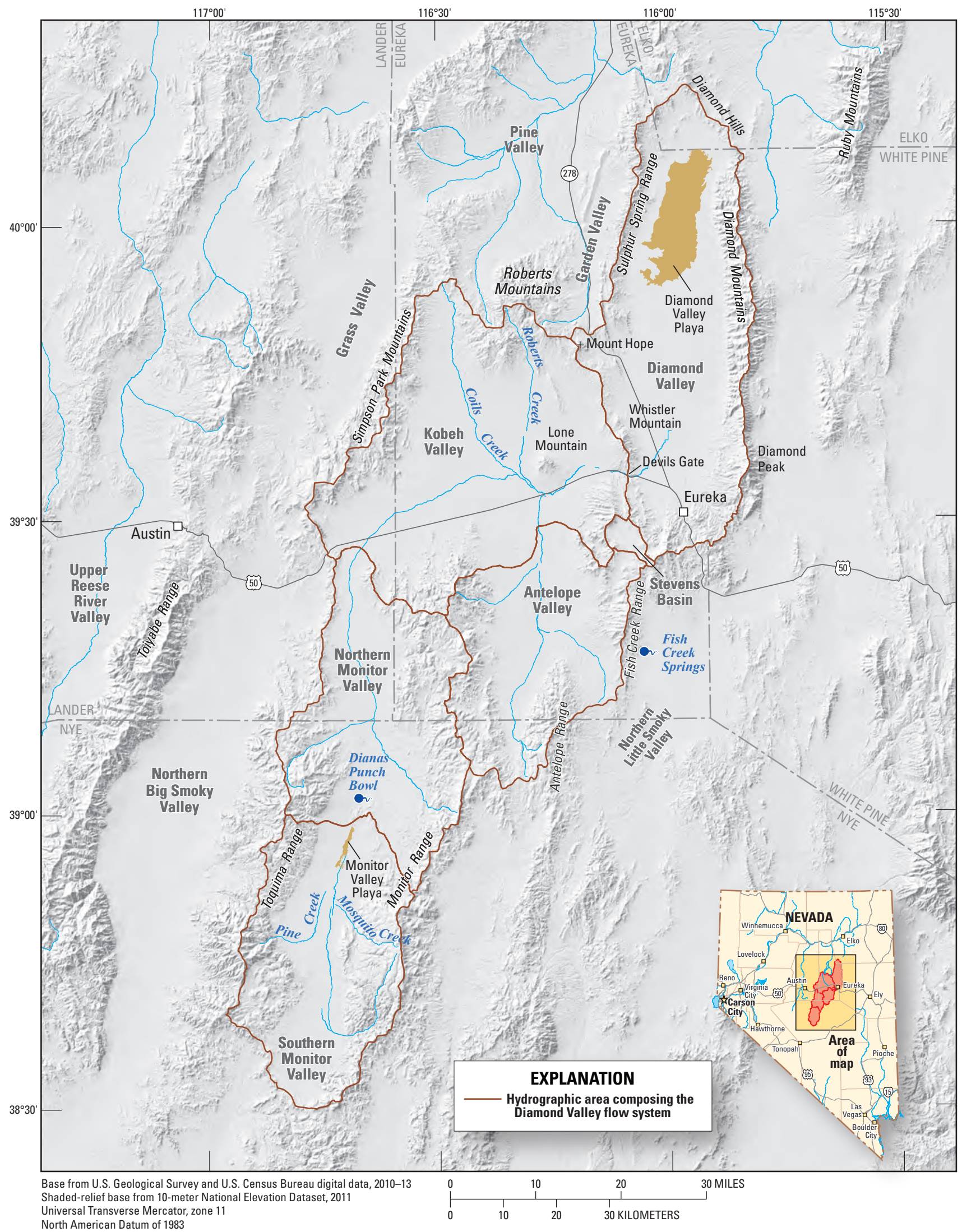

Figure 1. Hydrographic areas and selected geographic features in the Diamond Valley flow system, central Nevada. 
Budgets and Chemical Characterization of Groundwater for the Diamond Valley Flow System, Central Nevada, 2011-12

Hardman (1936) and Hardman and Mason (1949) to estimate groundwater recharge using an empirical method known as the Maxey-Eakin Method (Maxey and Eakin, 1949; Eakin and others, 1951). At the time of these studies, groundwater discharge in the area was dominated by evapotranspiration (ET) from areas with phreatophytic vegetation, and, to a much lesser degree, by evaporation from playas. Groundwater ET is composed of evaporation from bare-soil surfaces with transpiration by phreatophytes. Natural groundwater discharge through ET was estimated by applying assigned groundwater ET and groundwater evaporation rates to areas of phreatophytes and playas, respectively. These assigned rates were adopted from studies outside the study area (Lee, 1912; White, 1932; Young and Blaney, 1942). Groundwater discharge was not estimated from the large playa in the northern part of Diamond Valley (Eakin, 1962). The resultant balance between groundwater recharge and discharge developed by the two studies indicated that recharge was about 70 percent of discharge in Diamond Valley and about 120 percent of discharge in the other four basins.

In the early 1960s, the State Engineer became concerned about the increasing groundwater withdrawals in southern Diamond Valley. In response, the USGS performed a more detailed evaluation of the hydrology of Diamond Valley with an emphasis on the effects of groundwater withdrawals as of 1965 (Harrill, 1968). To facilitate the analysis, Harrill (1968) divided Diamond Valley into north and south subareas. Nearly all the natural discharge was in the north subarea, whereas nearly all major groundwater development was in the south subarea. As part of the reappraisal, two groundwater-level surfaces were created-pre-development (1950) and postdevelopment (1965). Additionally, a revised precipitationaltitude relation was developed on the basis of the available precipitation data. Harrill (1968) concluded that average annual precipitation was generally greater in the northern subarea than in the southern subarea and that the precipitationaltitude relation in the southern subarea probably was similar to that in Kobeh Valley. This north-south division in precipitation resulted in a 30 percent increase in precipitation-derived groundwater recharge when compared to estimates by Eakin (1962). Harrill (1968) developed a groundwater budget for Diamond Valley that included inflow components of recharge from precipitation, subsurface flow from Kobeh Valley through Devil's Gate, and subsurface flow from Garden Valley (outside the flow system) to the northwest of Diamond Valley (fig. 1). Outflow components of the budget included groundwater discharge by (1) ET from phreatophyte-dominated areas, (2) springs, and (3) playa evaporation. Groundwater chemical analyses allowed Harrill (1968) to develop a general relation between water chemistry and groundwater flow. Groundwater in Diamond Valley, except that in the shallow aquifer in the north subarea, was generally suitable for irrigation, stock, and domestic use. Harrill (1968) cautioned that continued groundwater withdrawals could cause the reversal of natural gradients toward the playa and induce flow of poor-quality water toward the developed areas in the south subarea.
The DVFS, as it is currently defined, consists of the six basins in the study area and was first recognized and delineated by Harrill and others (1983) and Harrill and others (1988) in an effort to improve the understanding of groundwater flow on a regional scale (Regional Aquifer Systems Analysis, or RASA). Using the limited existing data at the time, flow-system boundaries were generally defined and guided by regional-flow potential lines based on groundwater altitudes. A basic premise for flow-system delineation was that each flow system terminated in a discharge area.

Two reports have been published as part of the phased approach of the (2005-12) study. The phase 1 study (2005-06; Tumbusch and Plume, 2006) defined the hydrogeologic framework of the flow system, evaluated the presence and movement of groundwater, and quantified historical waterlevel changes. The phase 2 study (2006-09; Knochenmus and others, 2011) provided data collected from 2006 to 2009 and described the general approach for estimating natural groundwater discharge as part of phase 3 .

\section{Hydrologic Setting}

Nearly all water in the study area originates as precipitation, either in the form of rain or snow. Some of the precipitation runs off, most is evaporated or consumed by vegetation, and some eventually recharges the groundwater system. Streams in the study area generally are ephemeral and flow only during spring runoff or as a result of intense storms; however, some streams in the upper reaches of the watershed are perennial, but typically infiltrate before reaching the valley floor. Groundwater in the basin-fill aquifer is under confined and unconfined conditions and is derived from infiltration of mountain-block precipitation and streamflow. The movement of groundwater is controlled, in part, by the hydrogeology. The hydrogeology in the DVFS consists of carbonate rocks, siliciclastic sedimentary rocks, igneous intrusive rocks, volcanic rocks, and basin-fill deposits (plate 1). Details on the hydrogeologic units identified in the study area and their water-bearing characteristics can be found in Tumbusch and Plume (2006).

A separate, cooperative monitoring program by the USGS and Eureka County designed to collect streamflow and groundwater data in and around the southern extent of the Roberts Mountains (figs. 1, 2) began in 2010. The monitoring program includes continuous data collection at 5 surfacewater and 1 groundwater site, 13 miscellaneous streamflow and 3 groundwater-level measurements, and water-chemistry sampling at 13 sites. The program was designed to characterize baseline hydrologic conditions in response to a proposed molybdenum mine in the Mount Hope area (fig. 1). As part of this program, seepage was estimated along two streams that originate in the Roberts Mountains. 


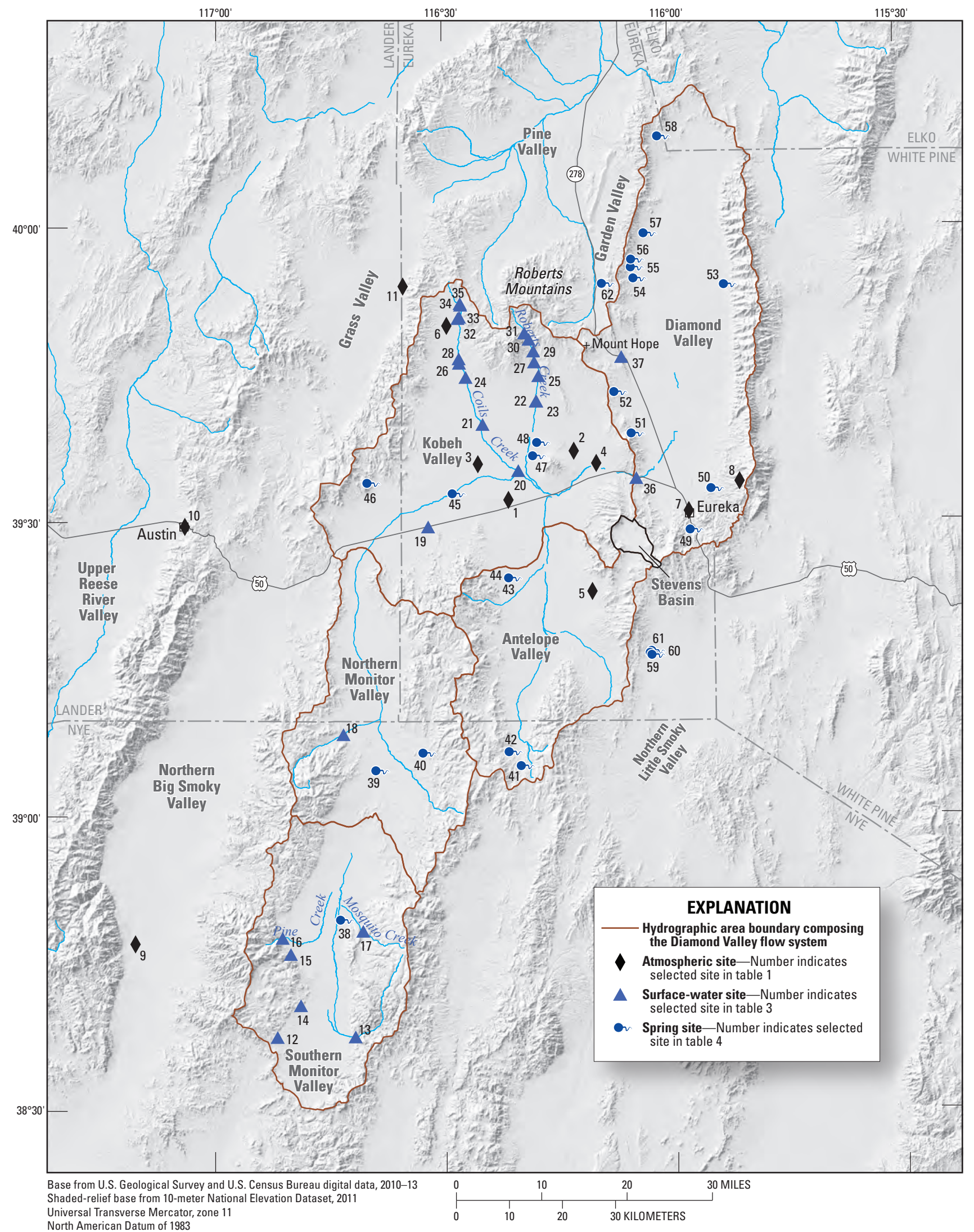

Figure 2. Atmospheric sites, surface-water sites, and spring sites in the Diamond Valley flow system, central Nevada. 


\section{Climate}

The climate of central Nevada generally can be divided into two zones. The valley floors are part of the mid-latitude steppe zone, which is semiarid with warm to hot summers and cold winters. The surrounding mountain ranges are a part of the subhumid continental zone, with cool to mild summers and cold winters, where annual precipitation is mostly snow (Houghton and others, 1975). The majority of the precipitation comes from the Pacific Ocean as winter storms. Localized summer thunder storms can produce large amounts of rain, but do not contribute much to the total annual precipitation in the area.

Climate conditions vary considerably in the study area by location, altitude, and seasonality. Climate data based on long-term averages can be advantageous for comparison of discontinuous or recent short-term datasets with historical conditions. Continuous long-term climate data were very limited in the study area; however, 30-year averages could be computed from selected sites near the study area (Western Region Climate Center, 2015; National Centers for Environmental Information, 2016). The closest climate stations that had annual precipitation and temperature data for a 30-year period (1981-2010) included Austin number 2, Beowawe $49 \mathrm{~S}$ (U of N Ranch), Eureka, and Smoky Valley Carvers (sites 10, 11, 7, and 9; respectively, fig. 2; tables 1, 2). Weather stations in the study area (fig. 2; tables 1,2) that had between 20 and 30 years of annual climate data included Diamond Peak Snow Telemetry (SNOTEL, 1984-2012, site 8), Coils Creek Remote Automatic Weather Station (RAWS, 1990-2012, site 6), and Combs Canyon RAWS (1986-2012, site 5). As part of this study, precipitation and temperature data (2011-12) were collected at four ET sites established in Kobeh Valley (sites 1-4; fig. 2; tables 1, 2).
Average monthly temperatures over the 30-year period (1981-2010) in Austin, Beowawe, Eureka, and Smoky Valley ranged from a low of 26-31 degrees Fahrenheit $\left({ }^{\circ} \mathrm{F}\right)$ in December and January to a high of $69-73^{\circ} \mathrm{F}$ in July. Although these weather stations mostly lie outside the DVFS, the temperature range is likely comparable to that of similar altitudes in the study area. During the 1991-2010 period, average monthly temperatures at higher altitudes, represented by Diamond Peak, ranged from 26 to nearly $66^{\circ} \mathrm{F}$.

A simple linear relation (fig. 3) between the station altitude and the 30-year average annual precipitation (1981-2010) was developed for Austin (6,780 ft), Beowawe (5,740 ft), Eureka $(6,430 \mathrm{ft})$, and Smoky Valley $(5,647 \mathrm{ft})$. The relation was used to compare the long-term average annual precipitation to that measured in the study area for water years ${ }^{1} 2011$ and 2012. About 87 percent of the variability in average annual precipitation at the four long-term weather stations can be explained by altitude. Precipitation collected from stations, including those within the study area (Coils Creek, Combs Canyon, Eureka, and the four Kobeh Valley ET sites), was generally greater in 2011 and less in 2012 than the long-term average (1981-2010). At the Kobeh Valley ET sites, 2011 precipitation averaged 1.3 times more than the long-term average, whereas 2012 values averaged 1.2 times less than the long-term average. For stations with complete precipitation records for water years 2011 and 2012, precipitation in water year 2011 was 17-55 percent greater than in 2012 .

\footnotetext{
${ }^{1}$ A water year is the period from October 1 to September 30 and is designated by the year in which it ends. Water year is used almost exclusively throughout this report. In order to reduce confusion between calendar years and water years in this report, all reference to years and periods is to water years, unless specifically referred to as a calendar year.
}

Table 1. Location and general description of atmospheric measurement sites, Diamond Valley flow system, central Nevada.

[Latitude and longitude values are in the North American Datum 1983. Altitude values are in the North American Vertical Datum 1988. USGS, U.S. Geological Survey; NOAA, National Oceanic and Atmospheric Administration; ET, Evapotranspiration; WX, general weather; GHCND, Global Historical Climatology Network-Daily]

\begin{tabular}{|c|c|c|c|c|c|c|c|c|}
\hline $\begin{array}{c}\text { Site } \\
\text { number }\end{array}$ & Hydrographic area & $\begin{array}{l}\text { USGS or NOAA station } \\
\text { identifier }\end{array}$ & Local or site name & $\begin{array}{l}\text { Latitude } \\
\text { (degrees) }\end{array}$ & $\begin{array}{r}\text { Longitude } \\
\text { (degrees) }\end{array}$ & $\begin{array}{c}\text { Altitude } \\
\text { (feet) }\end{array}$ & $\begin{array}{l}\text { Available } \\
\text { data }\end{array}$ & Figure(s) \\
\hline 1 & Kobeh Valley & 1393214116212402 & Sparse shrubland & 39.5371 & 116.3576 & $6,098.7$ & ET, WX & $2,17,18 \mathrm{~B}$ \\
\hline 2 & Kobeh Valley & 1393711116124501 & $\begin{array}{l}\text { Moderate-to-dense } \\
\text { shrubland }\end{array}$ & 39.6197 & 116.2134 & $6,051.8$ & ET, WX & $2,17,18 \mathrm{~B}$ \\
\hline 3 & Kobeh Valley & 1393553116252401 & $\begin{array}{l}\text { Moderate-to-dense } \\
\text { shrubland }\end{array}$ & 39.5981 & 116.4242 & $6,131.3$ & ET, WX & $2,17,18 \mathrm{~B}$ \\
\hline 4 & Kobeh Valley & 1393555116094802 & Grassland & 39.5987 & 116.1642 & $6,012.5$ & ET, WX & $2,17,18 \mathrm{~B}$ \\
\hline 5 & Antelope Valley & ${ }^{2}$ GHCND:USR0000NCOM & Combs Canyon, NV US & 39.3814 & 116.175 & 6,590 & WX & 2 \\
\hline 6 & Kobeh Valley & ²GHCND:USR0000NCOI & Coils Creek, NV US & 39.8333 & 116.4917 & 6,800 & WX & 2 \\
\hline 7 & Diamond Valley & ${ }^{2}$ GHCND:USC00262708 & Eureka, NV US & 39.517 & 115.9621 & 6,430 & WX & 2 \\
\hline 8 & Diamond Valley & ${ }^{2} \mathrm{GHCND}: \mathrm{USS} 0015 \mathrm{~K} 03 \mathrm{~S}$ & Diamond Peak, NV US & 39.5667 & 115.85 & 8,000 & WX & 2 \\
\hline 9 & Northern Big Smoky Valley & ${ }^{2}$ GHCND:USC00267620 & $\begin{array}{l}\text { Smoky Valley Carvers, } \\
\text { NV US }\end{array}$ & 38.784 & 117.1739 & 5,647 & WX & 2 \\
\hline 10 & Upper Reese River Valley & ${ }^{2} \mathrm{GHCND}: \mathrm{USC} 00260507$ & Austin Number 2, NV US & 39.493 & 117.0675 & 6,780 & WX & 2 \\
\hline 11 & Grass Valley & ${ }^{2} \mathrm{GHCND}: \mathrm{USC} 00260800$ & $\begin{array}{l}\text { Beowawe } 49 \mathrm{~S} \text { U of } \mathrm{N} \\
\text { Ranch, NV US }\end{array}$ & 39.9004 & 116.5876 & 5,740 & WX & 2 \\
\hline
\end{tabular}

${ }^{1}$ USGS station identification; latitude, longitude, and altitude values are from the USGS National Water Information System (http://waterdata.usgs.gov/nwis).

${ }^{2}$ NOAA station identification; latitude, longitude, and altitude values are from the NOAA National Climatic Data Center (http://www.ncdc.noaa.gov). 


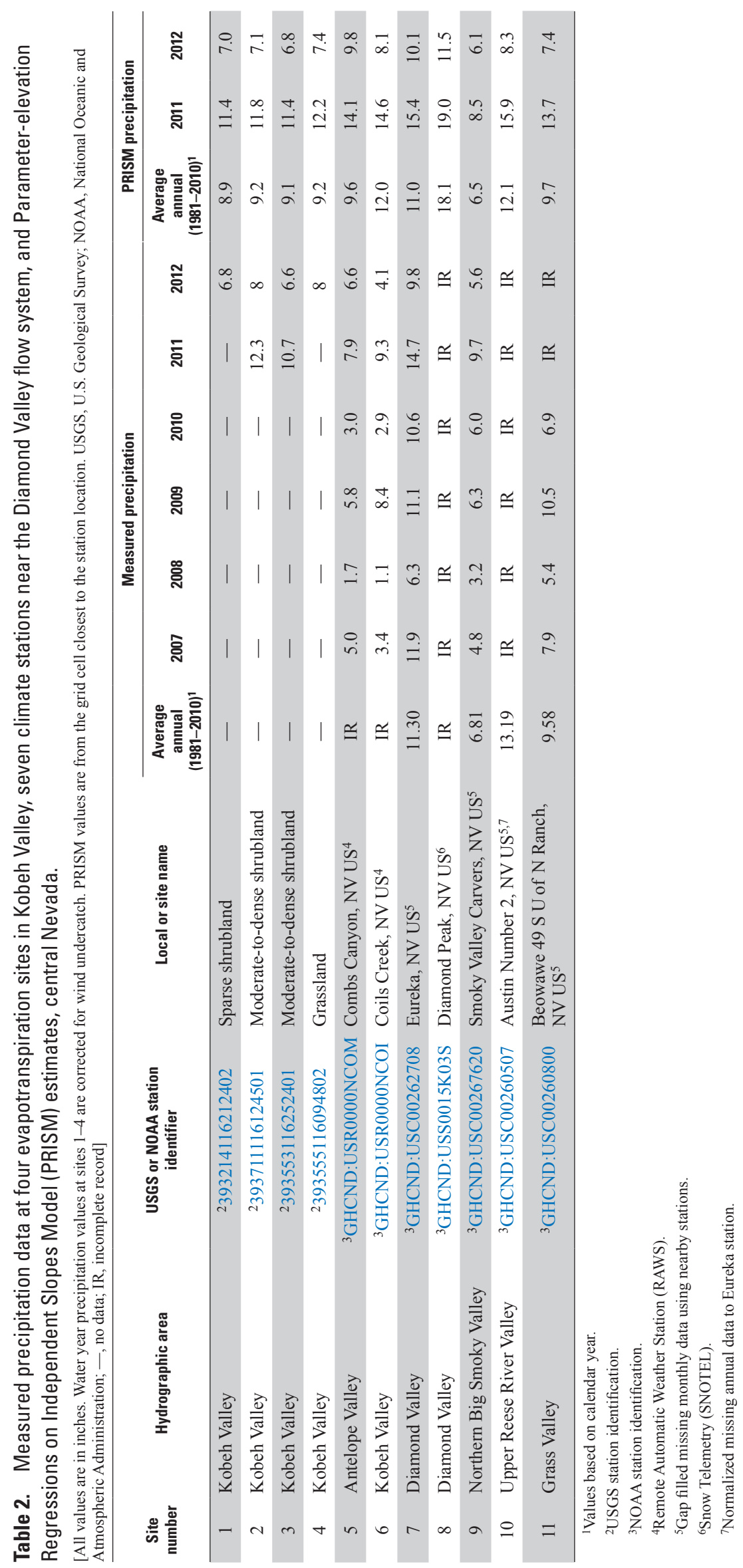



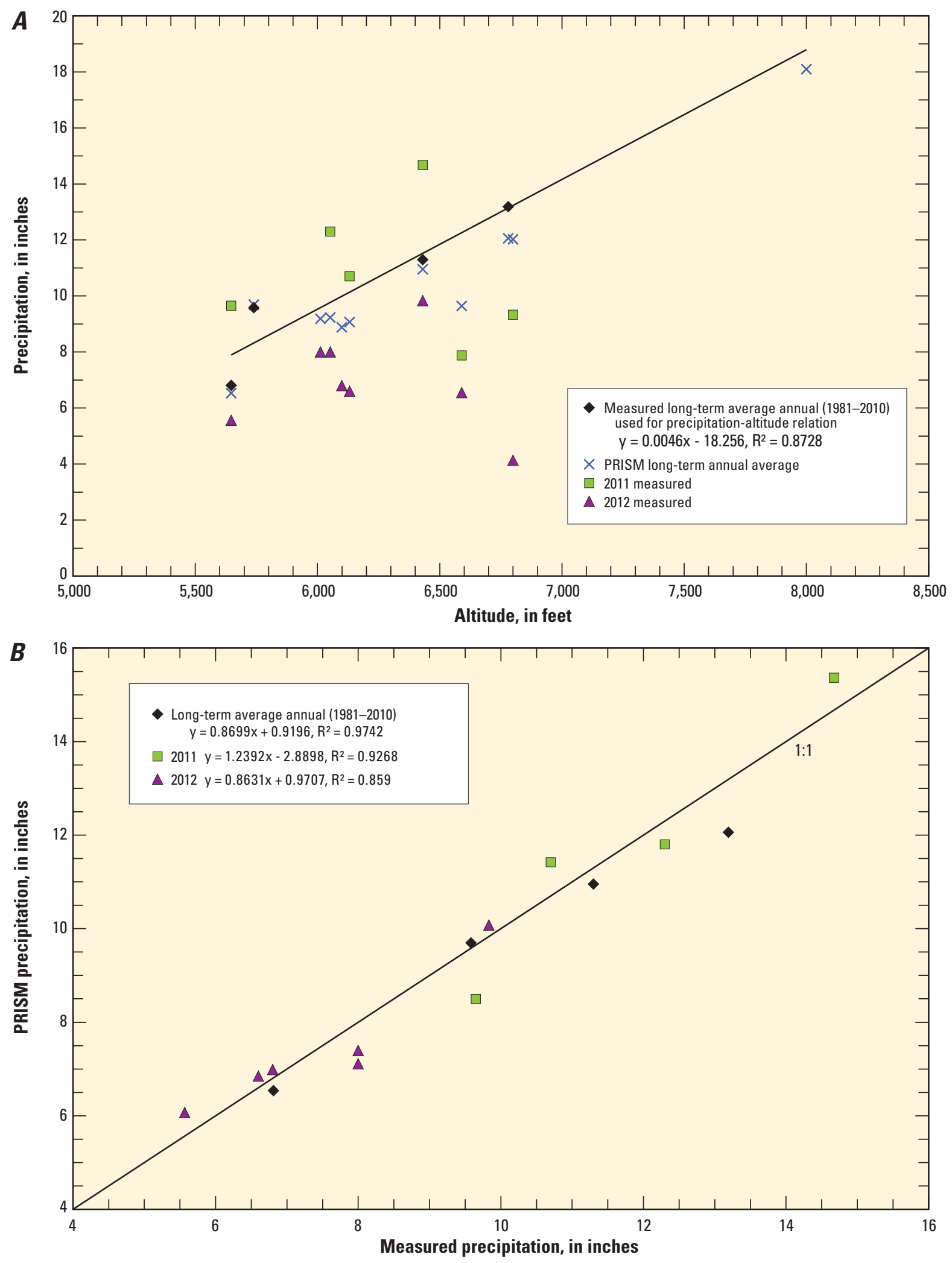

Figure 3. Comparison between average annual precipitation for four long-term precipitation stations (1981-2010), Diamond Valley flow system, central Nevada, and $\boldsymbol{A}$, station altitude, and $\boldsymbol{B}$, PRISM (Parameter-elevation Relationships on Independent Slopes Model) derived precipitation. 
Owing to the limited long-term precipitation and temperature datasets in the study area, long-term, average annual precipitation for Austin, Beowawe, Eureka, and Smoky Valley (1981-2010) was compared with 1981-2010 Parameter-elevation Relationships on Independent Slopes Model (PRISM; PRISM climate group, 2014; table 2) precipitation. Evaluation of long-term precipitation was relevant for evaluating pre-development groundwater ET rates across the DVFS (see the "Groundwater Discharge" section). The 30-year average annual PRISM estimates at the Austin, Eureka, and Smoky Valley sites were an average of 5-percent less than measured 30 -year average annual values, whereas the 30-year PRISM estimate at the Beowawe site was one percent greater than the measured 30-year value. Differences could, in part, reflect different accumulation periods and the generalized area of PRISM estimates (800-meter or 0.5 -mile cell size). Measured data were for water years 1981-2010, whereas PRISM data were for calendar years 1981-2010. Despite these differences, a least squares regression explained about 97 percent of the variability between measured and estimated values (fig. 3).

Comparisons between measured precipitation and PRISM data (table 2) also were made for water year 2011 at four sites and water year 2012 at six sites using least-squares regressions. The PRISM rates at Coils Creek (Kobeh Valley) and Combs Canyon (Antelope Valley) were consistently above measured values (by an average of 70 percent), and including these sites in multi-site comparisons between measured and PRISM values produced poor relations (coefficient of determination, or $\left.\mathrm{r}^{2}, 0.51-0.52\right)$. These precipitation stations were in steep, narrow canyons and steep terrain. Considering that water-year PRISM estimates are generalized to a 4-kilometer (2.5-mile) cell size, discrepancies between measured and estimated values in this terrain type were expected. Water year 2011 and 2012 relations that excluded these two sites were improved markedly ( $\mathrm{r}^{2} 0.96$ and 0.93 , respectively; fig. 3 ) and indicated that PRISM-estimated values largely captured the variability in precipitation measured across the study area. At ET sites on the floor of Kobeh Valley (see the "Evapotranspiration" section), annual measured and PRISM-estimated precipitation rates during 2011-12 were within 2 percent, on average (table 2). Site data were scaled to the basin and flowsystem level using remote sensing and long-term (1981-2010) PRISM data.

Annual precipitation data from Eureka (1966-2012) were used to evaluate trends in long-term climate conditions in the study area (fig. 4). The Eureka precipitation dataset was nearly complete, with 6 of the 48 years having missing data for no more than 3 months per year. The missing data were gap filled by using precipitation data from nearby stations. The estimated average annual precipitation at Eureka for the

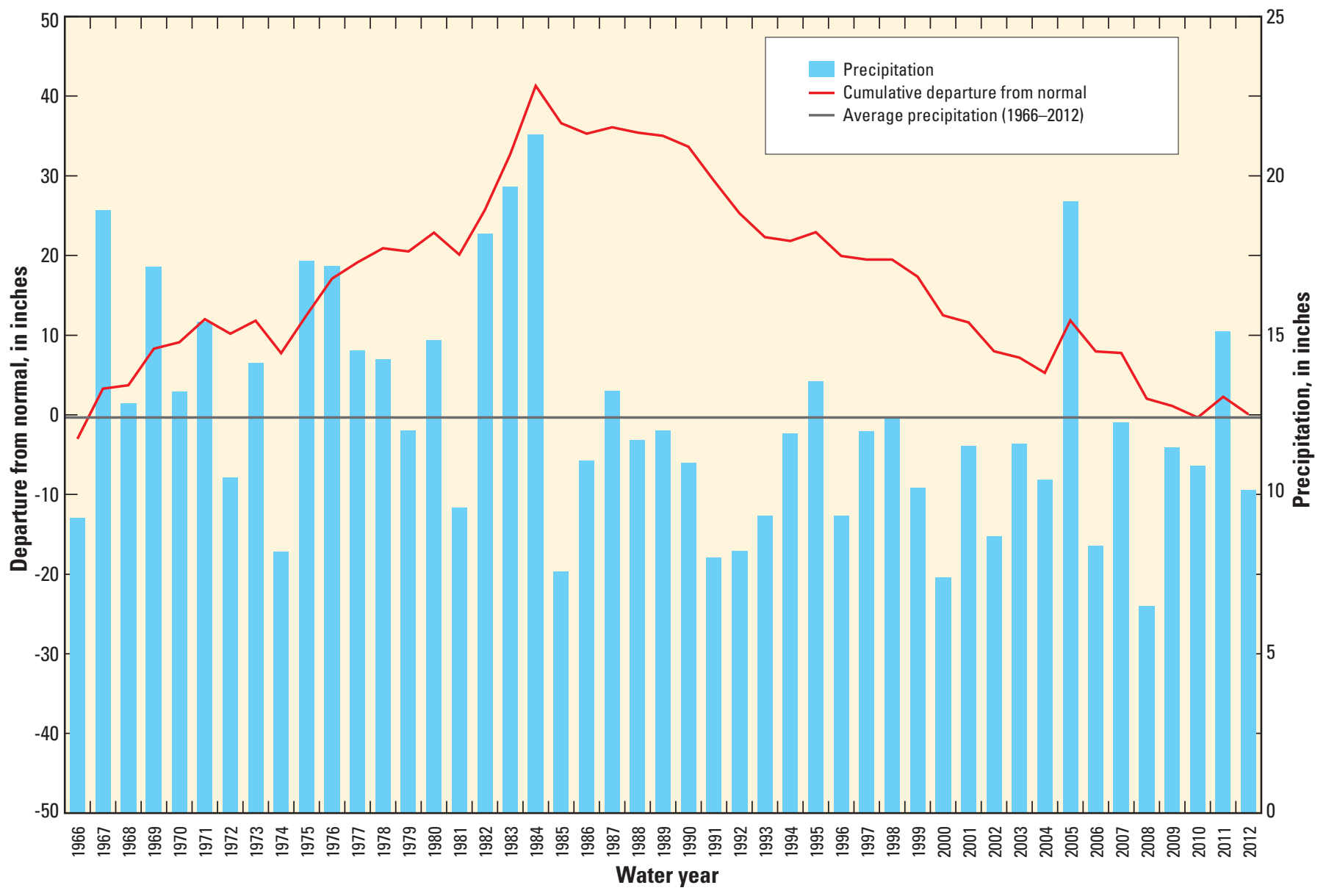

Figure 4. Annual water year precipitation and cumulative departure from normal (1966-2012), Eureka, central Nevada. 
48 years was 12.04 inches (in.). Cumulative departure from normal can be used to characterize trends in precipitation, where upward slopes indicate increased precipitation and downward slopes indicate declining precipitation. The graph of cumulative departure from normal for Eureka (fig. 4) shows an upward slope from 1966 to 1984, indicating most years had above average precipitation. From 1985 to 2012, the cumulative departure from normal indicated declining precipitation. In general, annual precipitation over the 28 years from 1985 through 2012 exhibited a trend of declining precipitation.

\section{Surface Water}

Daily streamflow data in the DVFS were available at 5 sites, and intermittent or peak discharge measurements collected over various periods were available at 21 sites (table 3 ). In April and May 1964, Rush and Everett (1964) collected 38 miscellaneous streamflow measurements in southern and northern Monitor, Antelope, and Kobeh Valleys. Harrill (1968) published a series of discharge measurements for 13 streams in Diamond Valley collected in 1965 and 1966. Additional streamflow data in southern and northern Monitor Valleys were available from three sites with continuous daily streamflow from 1977 generally through 2005 (sites 16-18; fig. 2; table 3) and from four sites with monthly discharge measurements from April 1997 to September 2000 (sites 12-15; fig. 2; table 3). In 2010, the USGS began collecting streamflow data at 2 sites (sites 26 and 29; fig. 2; table 3 ) and miscellaneous discharge data at 14 sites along Coils Creek and Roberts Creek in northern Kobeh Valley (sites 20-25, 27, 28, 30-35; fig. 2; table 3). As part of the 2010 monitoring program, the USGS also has been collecting miscellaneous discharge data at a site in Devil's Gate (site 36; fig. 2; table 3), which represents the only surface-water outflow from Kobeh Valley.

Infiltration of streamflow is a source of groundwater recharge. Most streamflow originates in the mountain block and infiltrates through coarse channel deposits on alluvial fans. Occasionally, under above-average conditions (for example, water year 2011) or following intense storm events, precipitation can generate streamflow that reaches the valley floor.

Table 3. Location and general information of surface-water measurement sites, Diamond Valley flow system, central Nevada.

[The locations of sites are shown on figure 2. Latitude and longitude values are in the North American Datum 1983. Altitude values are in the North American Vertical Datum 1988. Latitude, longitude, and altitude values are from the USGS National Water Information System (http://waterdata.usgs.gov/nwis). USGS, U.S. Geological Survey; Qm, miscellaneous discharge measurement; Qd, daily discharge; Qp, peak discharge; Qw, water quality]

\begin{tabular}{|c|c|c|c|c|c|c|}
\hline $\begin{array}{c}\text { Site } \\
\text { number }\end{array}$ & Hydrographic area & $\begin{array}{l}\text { USGS station } \\
\text { identifier }\end{array}$ & $\begin{array}{c}\text { Latitude } \\
\text { (degrees) }\end{array}$ & $\begin{array}{l}\text { Longitude } \\
\text { (degrees) }\end{array}$ & $\begin{array}{c}\text { Altitude } \\
\text { (feet) }\end{array}$ & $\begin{array}{c}\text { Available } \\
\text { data }\end{array}$ \\
\hline 13 & Southern Monitor Valley & ${ }^{1} 10245905$ & 38.6266 & 116.6967 & 7,255 & Qm \\
\hline 15 & Southern Monitor Valley & ${ }^{1} 10245901$ & 38.7669 & 116.8367 & 7,425 & Qm \\
\hline 16 & Southern Monitor Valley & ${ }^{1} 10245900$ & 38.7944 & 116.8545 & $7,564.73$ & Qd, Qm, Qp, Qw \\
\hline 19 & Kobeh Valley & ${ }^{1} 10245950$ & 39.4921 & 116.5342 & $6,204.23$ & Qp \\
\hline 20 & Kobeh Valley & 393513116200901 & 39.5869 & 116.3357 & 6,086 & Qm \\
\hline 21 & Kobeh Valley & 393956116244901 & 39.6657 & 116.4135 & 6,193 & Qm \\
\hline 22 & Kobeh Valley & 394217116174101 & 39.7046 & 116.2948 & 6,296 & Qm \\
\hline 26 & Kobeh Valley & 10245960 & 39.7698 & 116.4644 & 6,405 & Qd, Qm, Qp, Qw \\
\hline 27 & Kobeh Valley & 394616116175701 & 39.7712 & 116.2992 & 6,612 & Qm \\
\hline 28 & Kobeh Valley & 394638116275501 & 39.7774 & 116.4652 & 6,437 & Qm \\
\hline 29 & Kobeh Valley & 10245970 & 39.7898 & 116.3009 & 6,743 & Qd, Qm, Qp, Qw \\
\hline 30 & Kobeh Valley & 394835116183901 & 39.8098 & 116.3109 & 6,923 & Qm \\
\hline 31 & Kobeh Valley & 394914116191401 & 39.8206 & 116.3205 & 7,075 & Qm \\
\hline 32 & Kobeh Valley & 395045116280201 & 39.8458 & 116.4671 & 6,643 & Qm \\
\hline 33 & Kobeh Valley & 395052116275001 & 39.8479 & 116.4638 & 6,641 & Qm \\
\hline 34 & Kobeh Valley & 395206116274001 & 39.8684 & 116.4611 & 6,722 & Qm \\
\hline
\end{tabular}

${ }^{1}$ Inactive site. 
Seepage estimates can be used to establish a relation between streamflow and groundwater by delineating reaches that are gaining or losing streamflow at a particular time. Seepage was estimated using a series of eight discharge measurements along Coils Creek (sites 20, 21, 24, 28, 32-35; fig. 2; table 3) and seven measurements along Roberts Creek (sites 22, 23, 25, 27, 29-31; fig. 2; table 3) in spring 2011. On the basis of these discharge measurements, Coils Creek gained about 16 cubic feet per second (cfs) of streamflow in the upper reach between sites 35 and 26 (fig. 2; table 3). Downstream from site 26, Coils Creek began to lose flow where the channel crossed alluvial deposits. The discharge measurement taken farthest downstream (site 20; fig. 2; table 3) was $1 \mathrm{cfs}$, indicating that $16 \mathrm{cfs}$ of streamflow infiltrated beneath Coils Creek and recharged the shallow basin-fill aquifer. Similar gain and loss results were observed along Roberts Creek, where nearly $10 \mathrm{cfs}$ of streamflow was lost, likely infiltrating and recharging the shallow basin-fill aquifer beneath the stream. Although ET occurred along the measurement reaches, this loss was considered to be negligible compared with the streamflow loss.

Playas are flat, undrained, and unvegetated areas that typically are on a valley floor and periodically flood, accumulating fine-grained sediments and salts. Sediment grain size increases from the playa center toward the edge, which typically is bounded by phreatophytes and springs. Water can accumulate on playas from run-on of surface water, spring discharge, or direct precipitation. Surface morphology of Nevada playas typically ranges from hard, compact, generally smooth surfaces to soft, friable, or puffy surfaces. Hard surfaces typically reflect recent inundation by precipitation or run-on, whereas soft, puffy surfaces often reflect recent soil-water evaporation and subsequent salt deposition. A recent study by Garcia and others (2014) indicated that soft, puffy surfaces only were present following cool season precipitation. Low potential ET during cooler months facilitated downward percolation of precipitation or run-on and mixing with resident saline soil water. Subsequent evaporation of this water provided a mechanism for salt migration to and deposition on the playa surface. Friable surfaces were apparent following percolation and subsequent evaporation of cool-season precipitation and during the warmest and driest time of year. The source of playa soil water can vary seasonally from percolation of precipitation or "run-on" to groundwater. Similarly, groundwater discharging from playas can be derived from a mix of local recharge from precipitation and run-on to the playa and regional groundwater recharge (Garcia and others, 2014). Additional research is required to fully understand the role playas play in hydrologic processes.

The DVFS contains two playas - a relatively small playa (about 1,400 acres) in the northern part of southern Monitor Valley and a large playa (about 43,000 acres) in northern Diamond Valley (fig. 1). Rush and Everett (1964) noted that the southern Monitor Valley playa was dry in mid-April, but was flooded from a subsequent storm and snowmelt in early May. Similar patterns were observed during this study. Along the northeast margin, the playa surface was occasionally moist from small groundwater seeps. North of this playa in the south part of northern Monitor Valley, numerous springs have created several wetland areas and associated aquatic vegetation. The playa covering most of the northern part of Diamond Valley is considered the terminus of the DVFS (Harrill and others, 1983). Similar to the much smaller playa in southern Monitor Valley, this large playa is bordered by phreatophytes. Harrill (1968) reported that fault-controlled warm springs exist along the western margin of the playa, and small, warm groundwater seeps exist along the eastern margin. The presence of numerous seeps and springs surrounding southern Monitor Valley and Diamond Valley playas is indicative of permeability contrasts between alluvial and playa sediments that limit groundwater flow within playas.

\section{Groundwater}

Nearly all groundwater in the DVFS originates from precipitation. Most precipitation falls, and consequently most groundwater recharges, in the higher altitudes of the mountainous regions within the DVFS. Some precipitation runs off as streamflow and eventually infiltrates through coarse channel deposits on alluvial fans. Groundwater in the basin fill generally is unconfined at shallow depths (water table) and confined at greater depths. Basin-fill deposits make up the principal aquifers in the DVFS and occupy structural basins in sedimentary and igneous rocks. Groundwater resides in the rock units that make up the mountain blocks and underlie the basins, but the connection to the basin-fill aquifer is poorly understood. Discharge of warm or hot water from springs or wells indicates deep circulation of groundwater, probably from carbonate or volcanic rock, at depth (Harrill, 1968; Tumbusch and Plume, 2006).

Groundwater flows down gradient from areas of recharge toward areas of discharge, and in the DVFS, groundwater flows toward the playa in northern Diamond Valley. Contours of water-level altitude are used to define the shape and gradient of the groundwater surface to indicate general directions of groundwater movement. As part of this study phase, 2012 groundwater levels (plate 1) were delineated largely on the basis of spring altitudes (fig. 2; table 4) and water-level data collected from wells (fig. 5; table 5). In Diamond Valley, the distribution of transmissivity and aquifer textures developed by Harrill (1968) also was used to guide the development of water-level contours. Most wells were measured in spring 2012; a few wells measured in 2005 could not be re-measured, but these were in areas of limited groundwater development and were assumed to be similar to the 2012 water table. The 2012 water-table surface can be compared to the 2005 watertable map (Tumbusch and Plume, 2006), where overlapping data exist, and to the 1950 pre-development water-table map in Diamond Valley (Harrill, 1968). In general, water-level altitudes and groundwater-flow directions have not changed since 2005 in southern and northern Monitor, Antelope, or Kobeh Valleys owing to the lack of groundwater development in those areas (sites 73, 83, 99, 140, 161; fig. 6). 


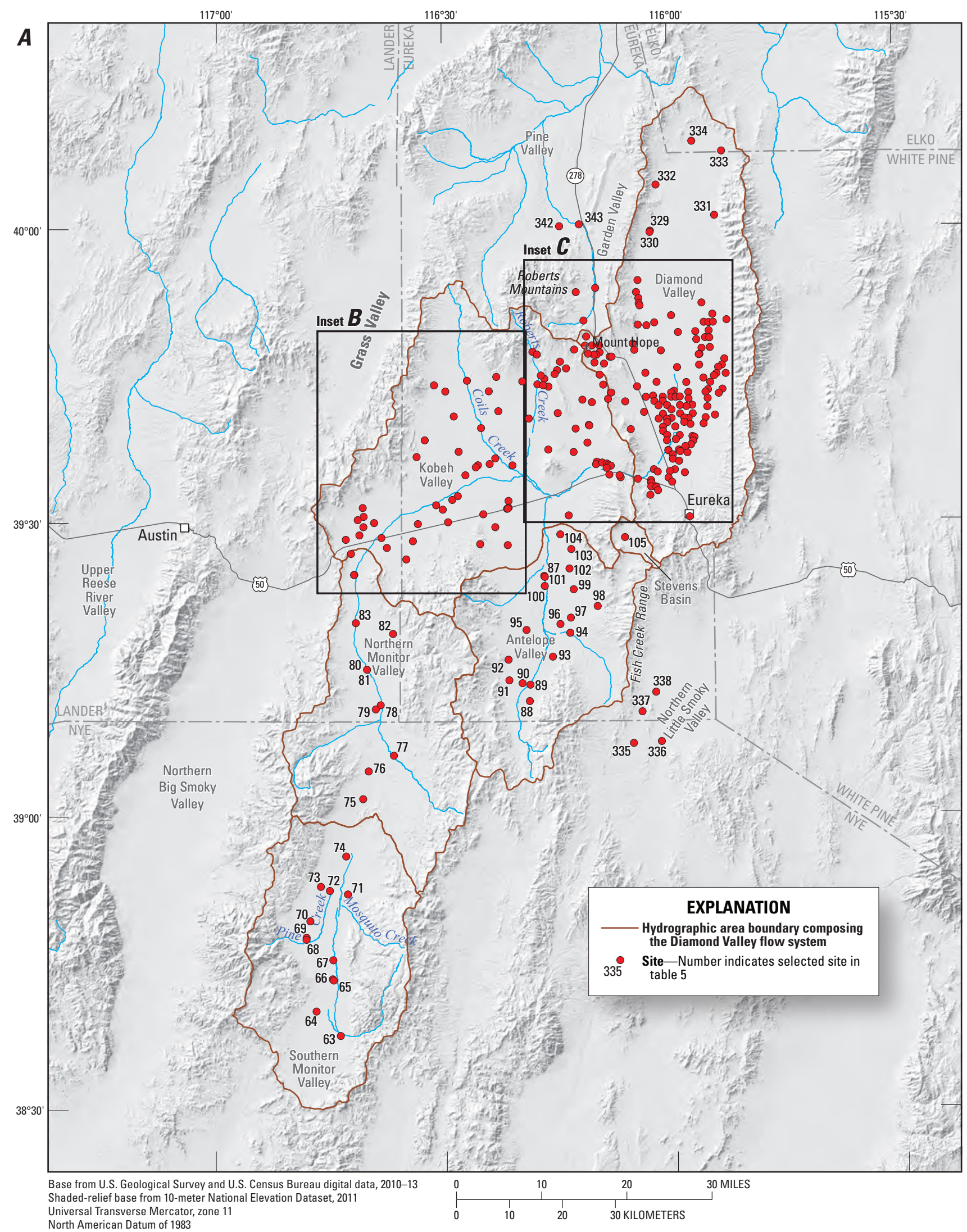

Figure 5. Groundwater sites in $\boldsymbol{A}$, the Diamond Valley flow system, central Nevada; $\boldsymbol{B}$, parts of northern Monitor and Kobeh Valleys; C, parts of Kobeh and Diamond Valleys. 


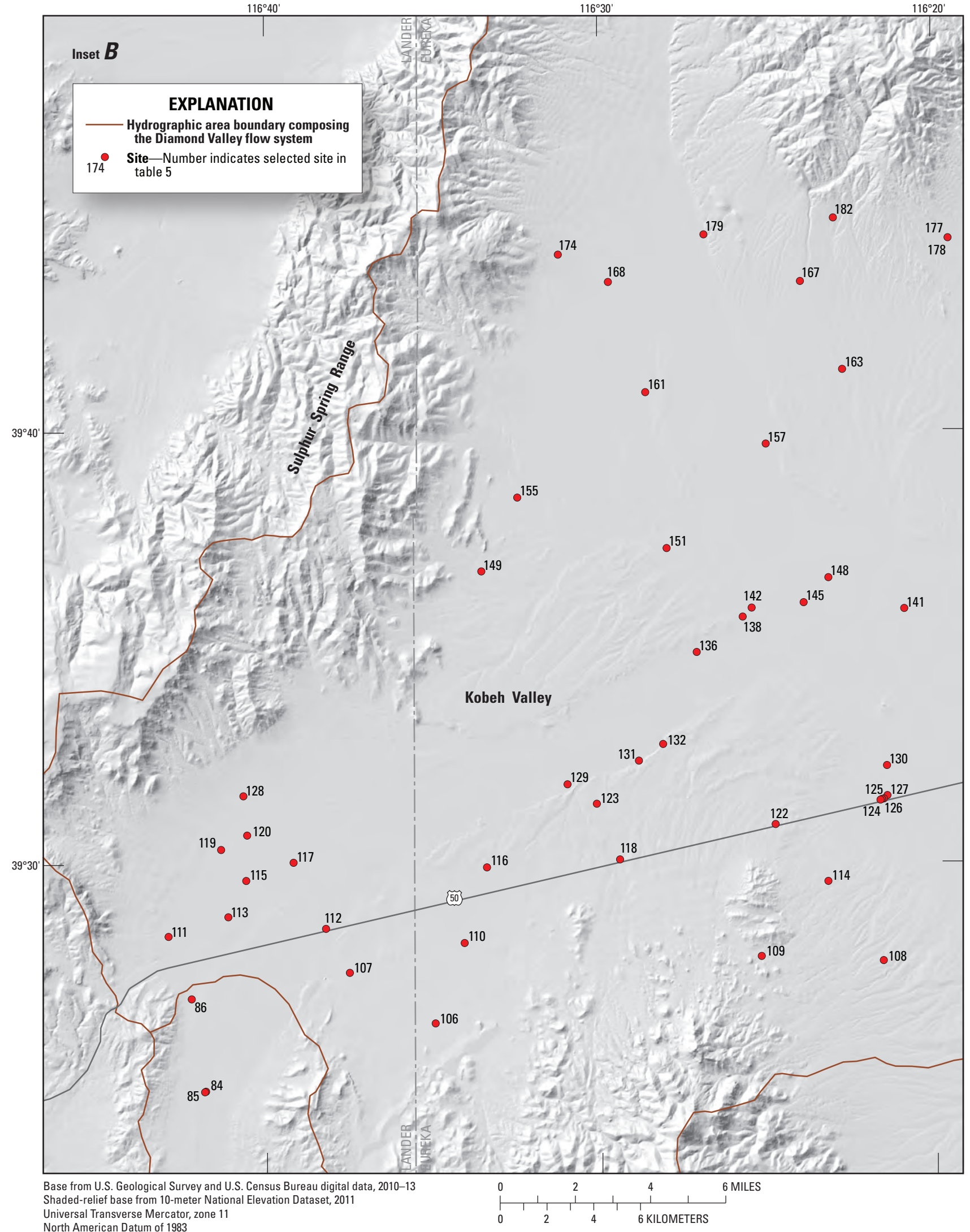

Figure 5. Groundwater sites in $\boldsymbol{A}$, the Diamond Valley flow system, central Nevada; $\boldsymbol{B}$, parts of northern Monitor and Kobeh Valleys; $\boldsymbol{C}$, parts of Kobeh and Diamond Valleys.-Continued 


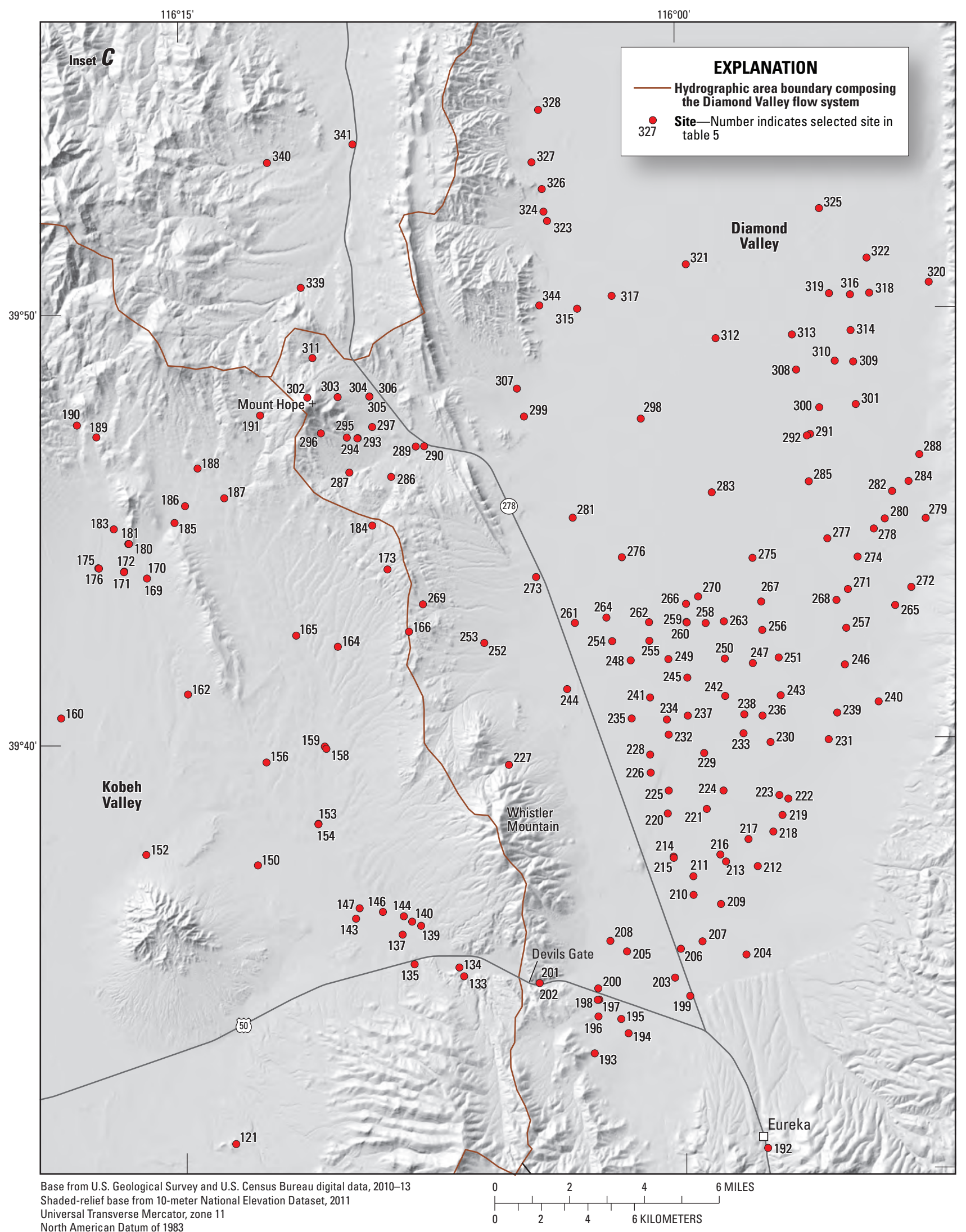

Figure 5. Maps showing groundwater sites in $\boldsymbol{A}$, the Diamond Valley flow system, central Nevada: $\boldsymbol{B}$, Kobeh Valley; $\boldsymbol{C}$, Diamond Valley.-Continued 


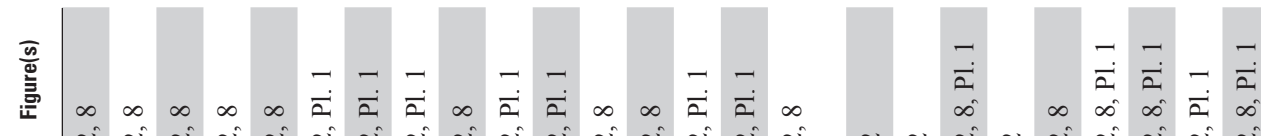

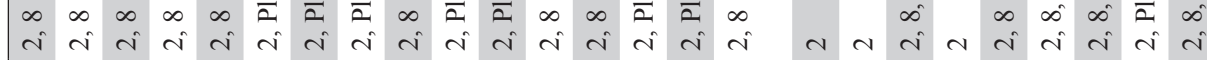

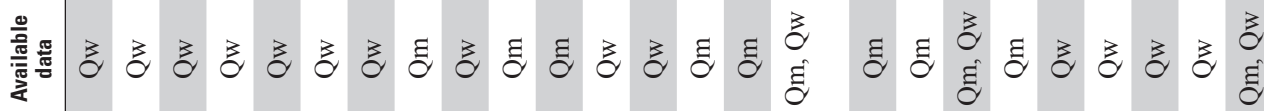

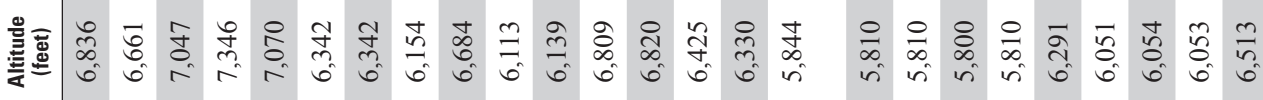

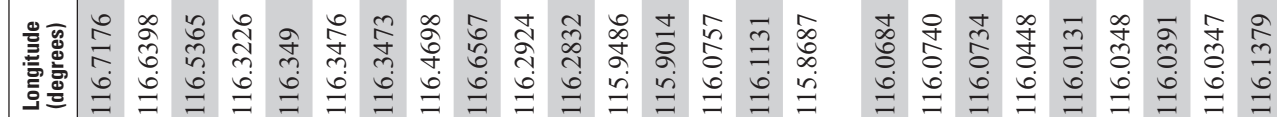

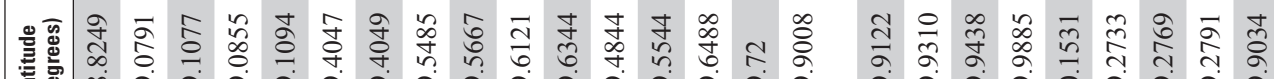

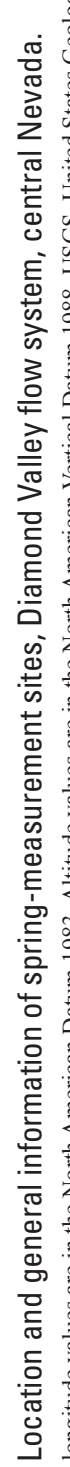

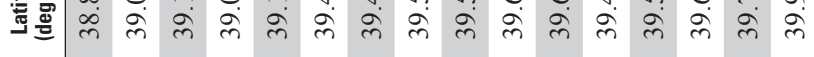

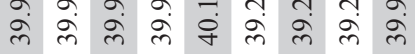

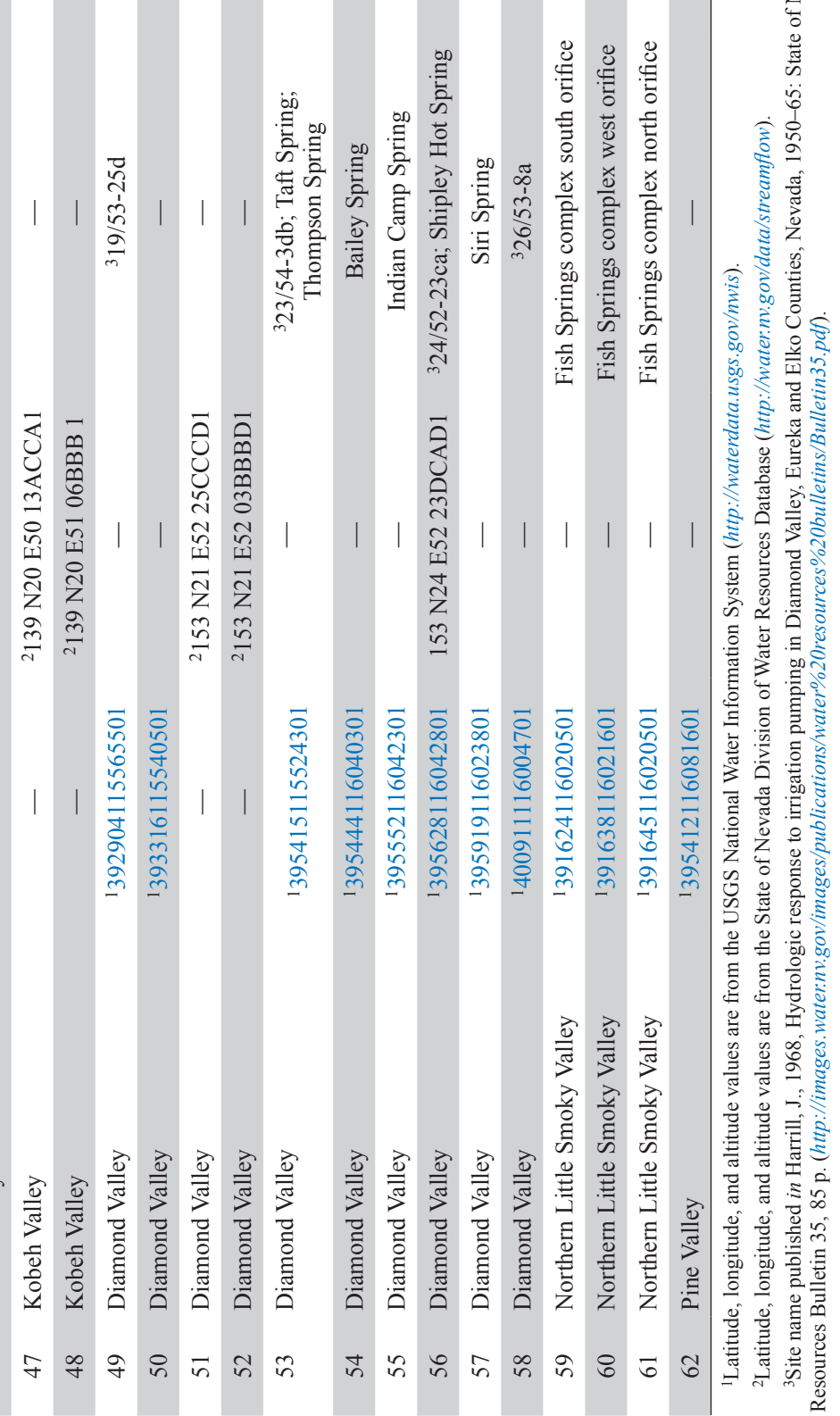



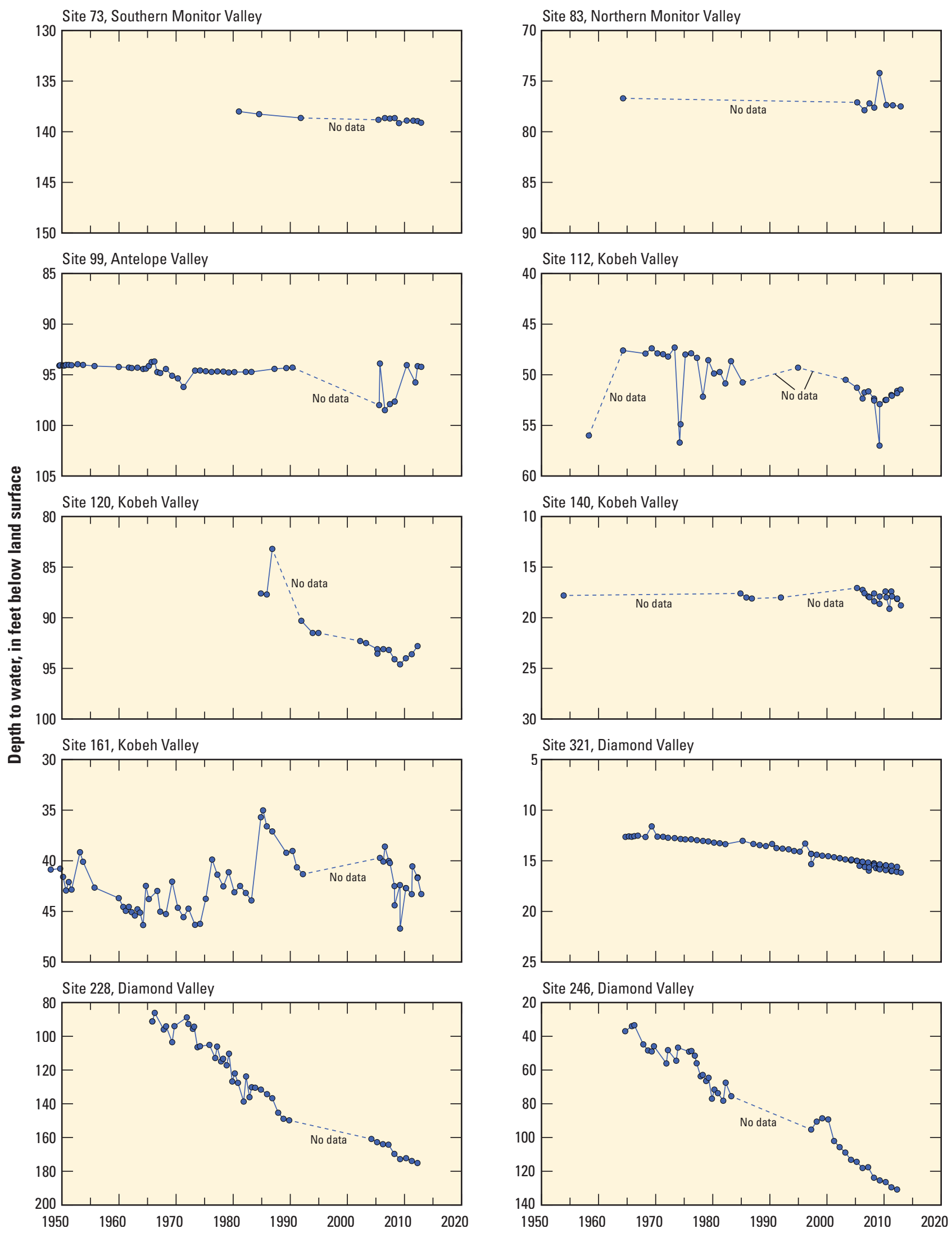

Figure 6. Water-level change in selected wells in the Diamond Valley flow system, central Nevada, 1950-2012. 
Water-level declines were observed from 2005 to 2012 in southern Diamond Valley (sites 228 and 246, fig. 6). Although the direction of groundwater flow in Diamond Valley in 2012 was similar to that in 2005 , as much as $21 \mathrm{ft}$ of decline was observed in the southern part of Diamond Valley during that 7-year interval (2005-12). A groundwater divide has formed between the area of natural discharge in the north part of Diamond Valley and the area of groundwater development in the south since Harrill's (1968) work in 1966. The groundwater divide has migrated northward since 2005, and its eastwest extent has decreased notably (site 321; plate 1; fig. 6). This migration indicates that the cone of depression caused by groundwater withdrawals in southern Diamond Valley expanded radially outward and had not reached equilibrium by 2012.

Since the mid-1960s, numerous springs, mostly along the western margin of the playa in the northern part of Diamond Valley, have declined in discharge or have stopped flowing entirely. Exact timing of the spring-flow decline is mostly unknown. Limited flow measurements at Taft-Thompson Spring (site 53; fig. 2; table 4), along the eastern margin, and at Shipley Hot Spring (site 56; fig. 2; table 4), along the western margin, indicated large flow declines took place in the mid-1980s to early 1990s (fig. 7). Spring-flow measurements collected in 1965-68 at five major springs (sites 53-57; fig. 2; table 4) in northern Diamond Valley ranged from 0.6 to
6.8 cfs. By 2011-12, only Shipley Hot Springs continued to flow, but only at nearly half the flow rate measured in 1990 . Observed decreases in spring discharge along the east and west margins of the playa in the northern part of Diamond Valley, in part, could have been induced by groundwater withdrawals in the south. Finger-like zones of relatively more transmissive basin-fill deposits along the west and east sides of Diamond Valley (Harrill, 1968) could provide an avenue for groundwater withdrawals in southern Diamond Valley to propagate northward and affect spring discharge in northern Diamond Valley.

Additional water-level data collected since 2005 and more accurate land-surface altitudes at selected well sites were used to improve estimates of groundwater flow between basins. Water-level data in the area between Kobeh and Diamond Valleys north of Whistler Mountain (sites 166, 173, 184, 269; fig. 5; table 5) indicated no groundwater flow across this boundary. Recent water-level altitudes in northern Little Smoky Valley, southeast of Antelope Valley, were as much as $200 \mathrm{ft}$ lower than water-level altitudes in the southern part of Antelope Valley (sites 94, 96, 97, 335, 337, 338; fig. 5; table 5). This difference in water-level altitude supports an inference by Rush and Everett (1966) that groundwater potentially flows eastward from the southern part of Antelope Valley through carbonate rocks of the southern Fish Creek Range and could be, in part, the source of flow at Fish Creek Springs (site 59-61; fig. 2; table 4), a regionally discharging

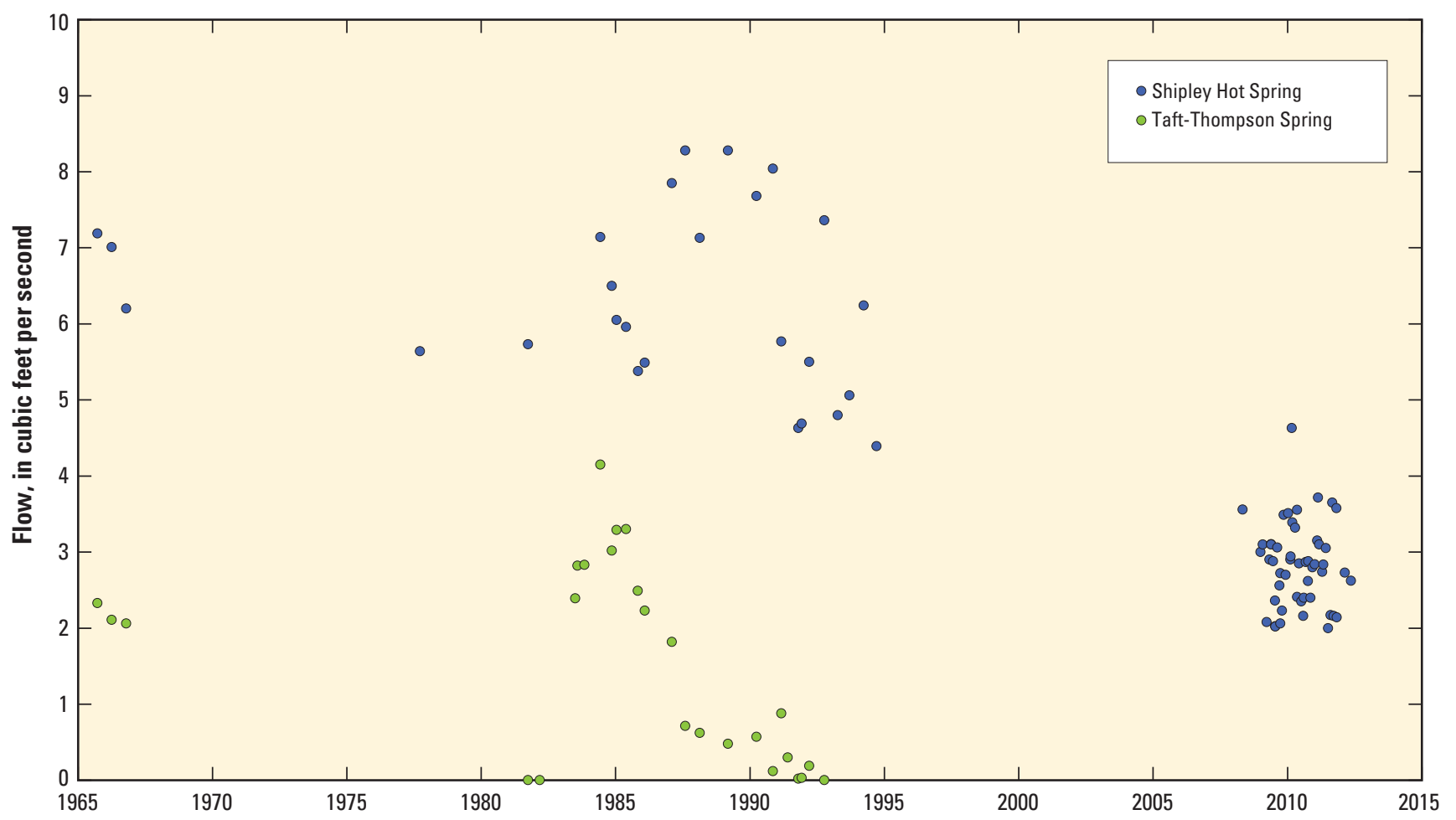

Figure 7. Miscellaneous spring-discharge measurements for Shipley Hot Springs and Taft-Thompson Spring, 1965-2012, Diamond Valley flow system, central Nevada. Spring discharge measurements from 2008 to 2012 were obtained from the Nevada Division of Water Resources (2013). 


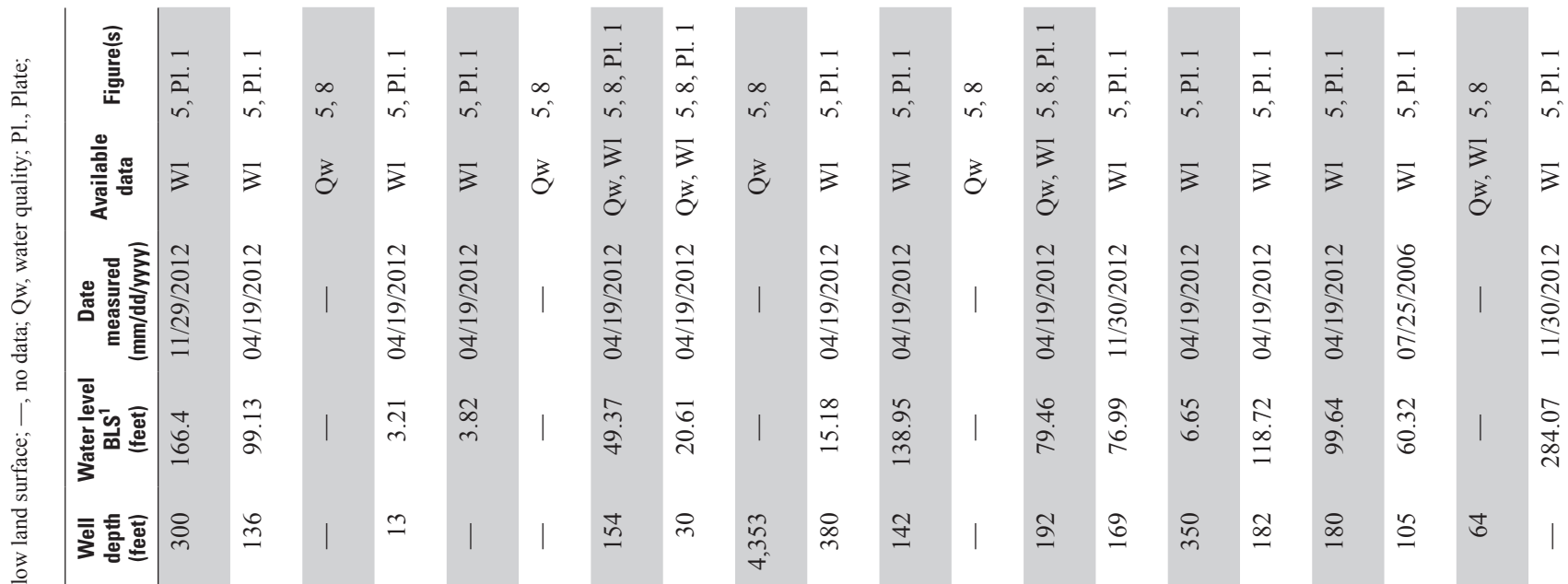

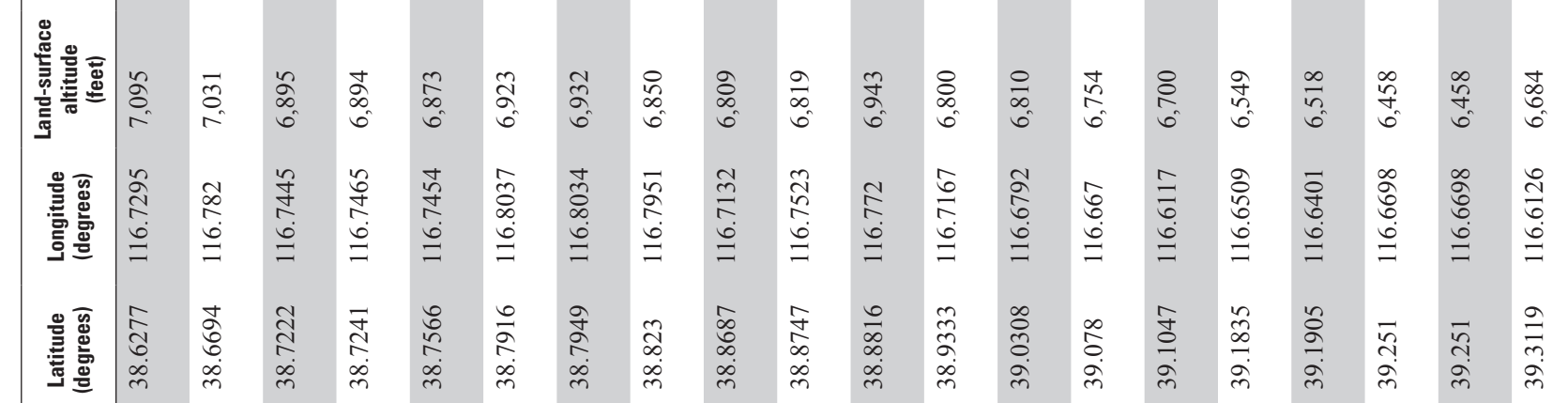

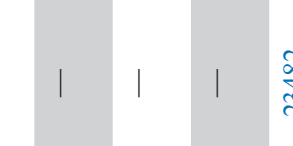

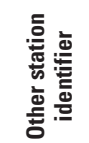
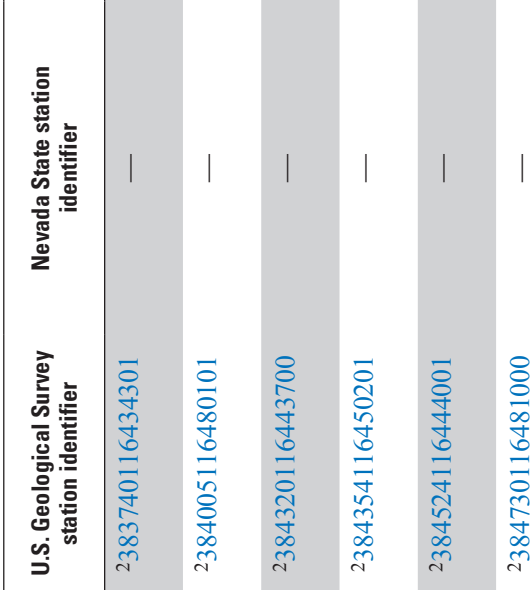

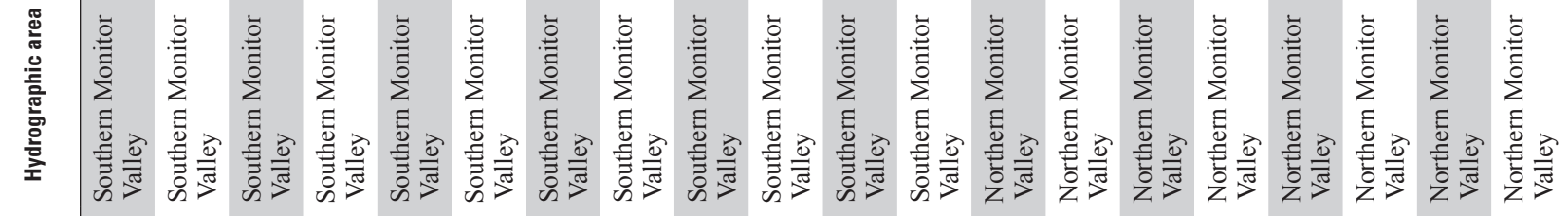

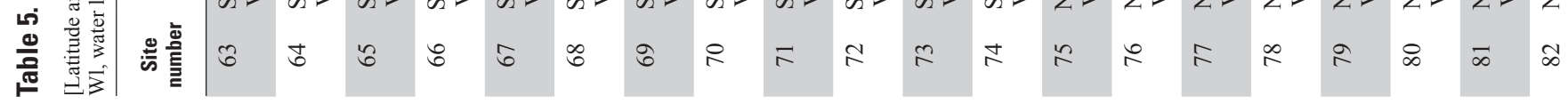




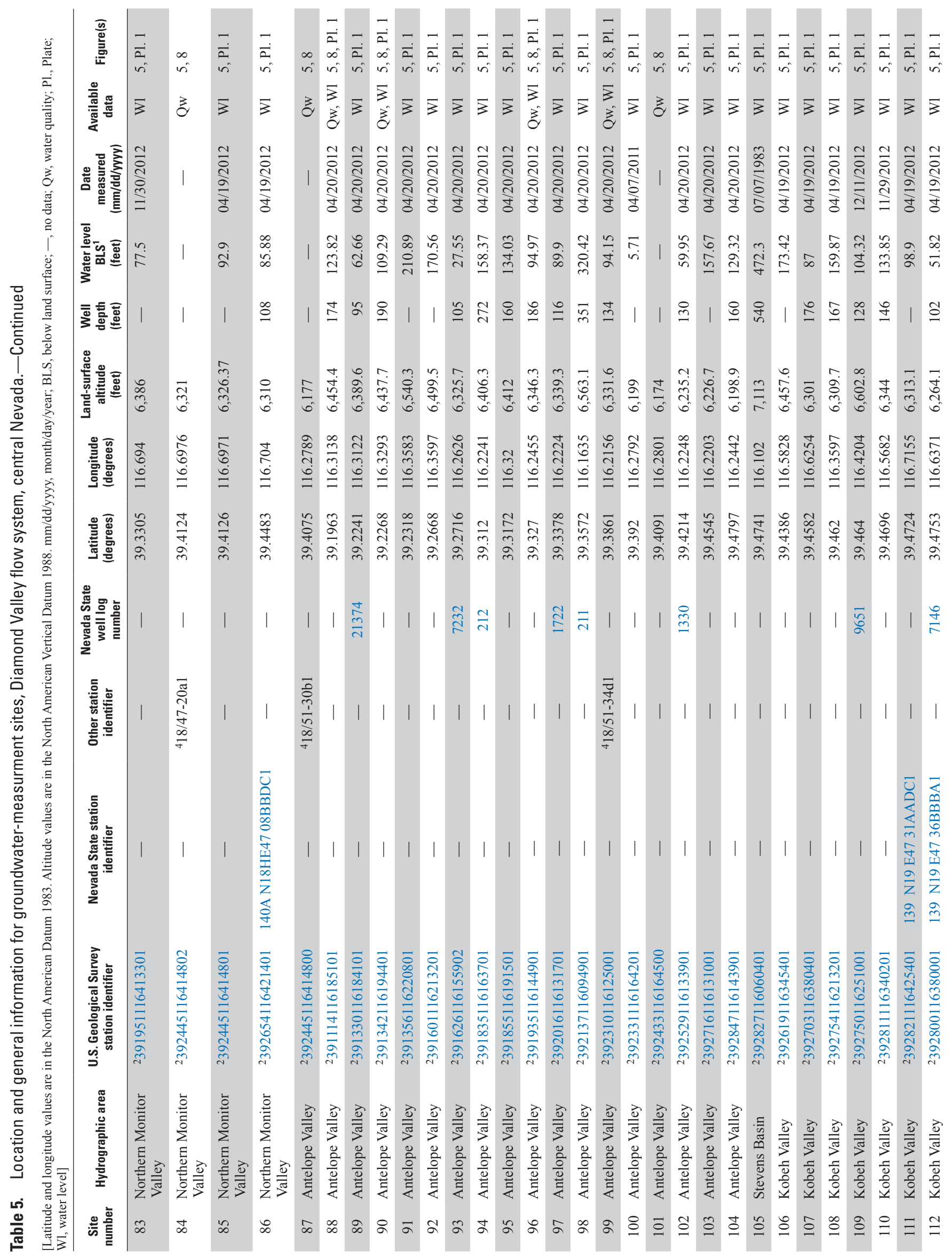




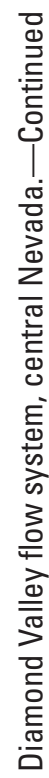

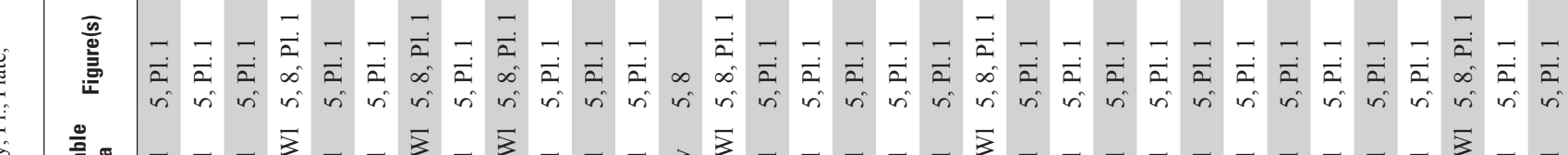

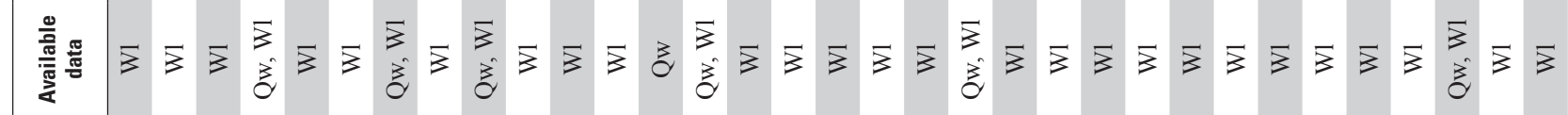

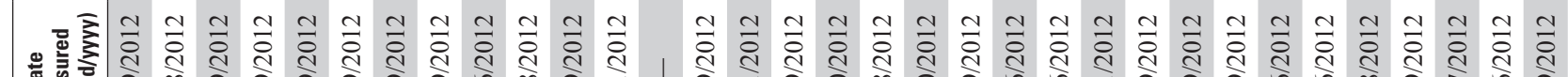

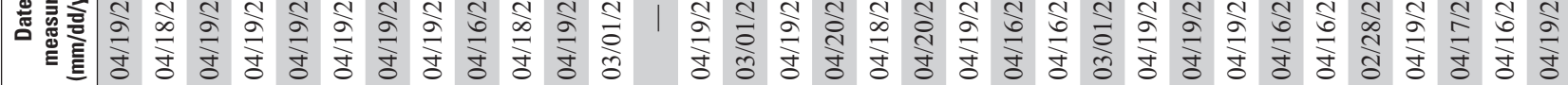

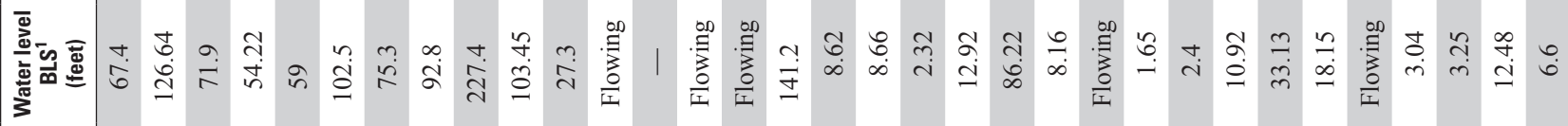
曾

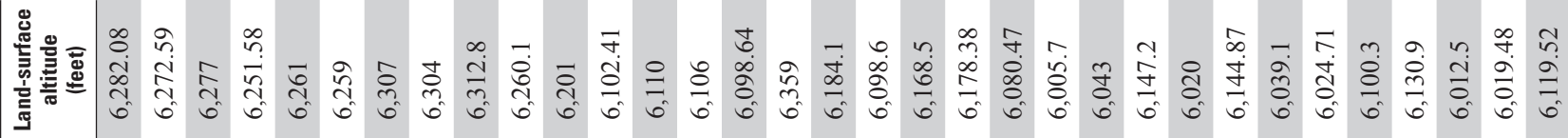

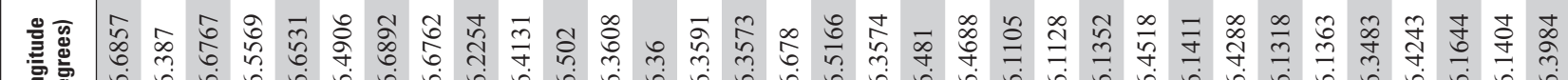

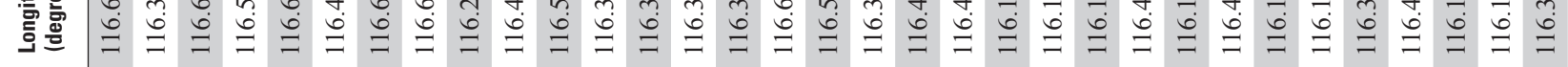

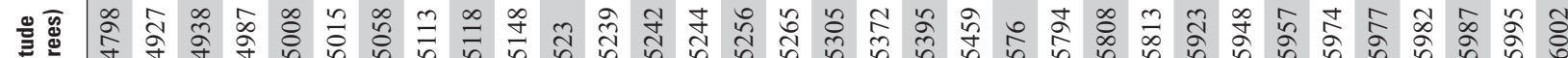

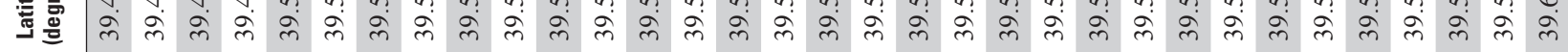

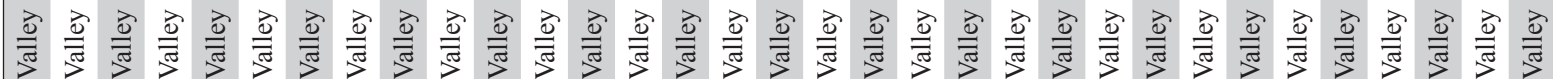

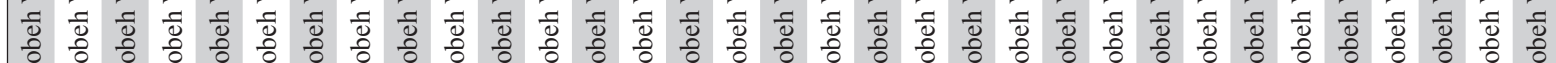

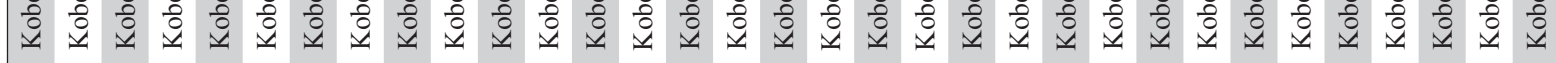

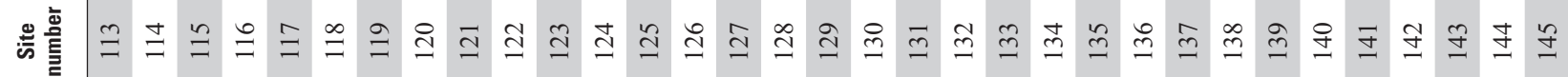




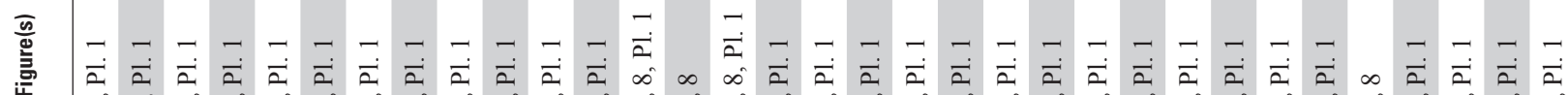

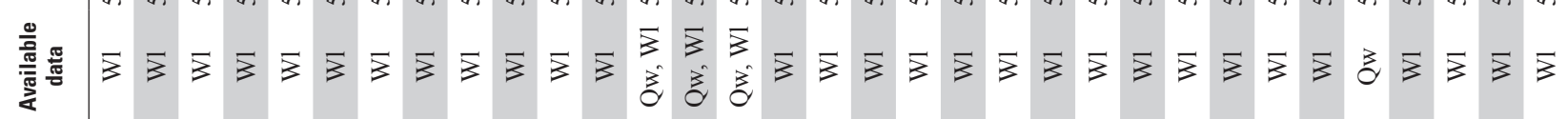
و

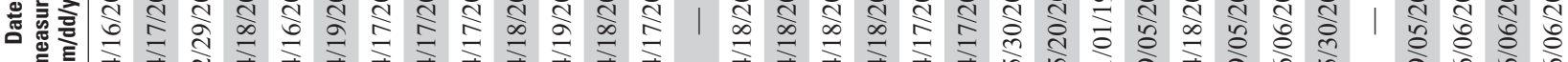

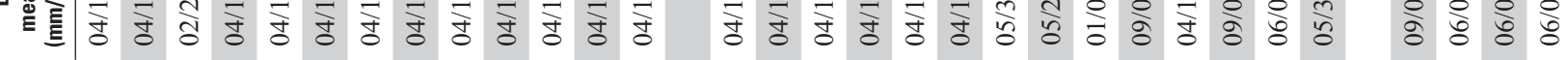

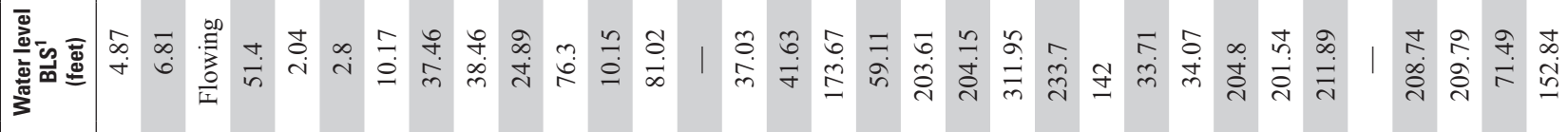

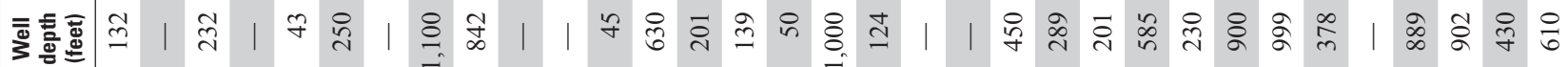

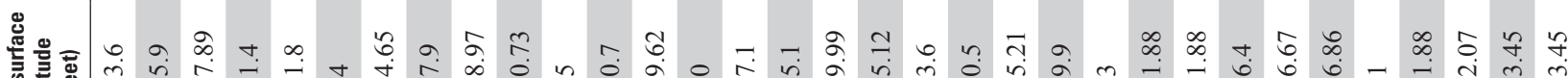

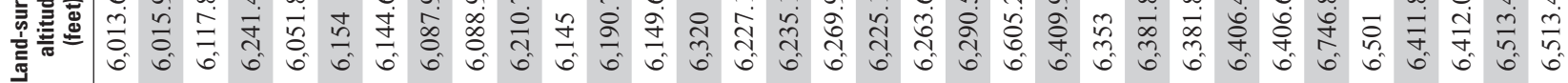

$$
\text { 㐫 }
$$

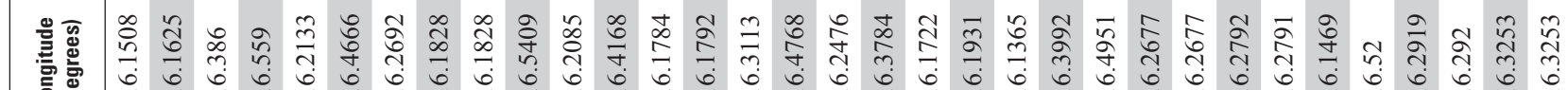

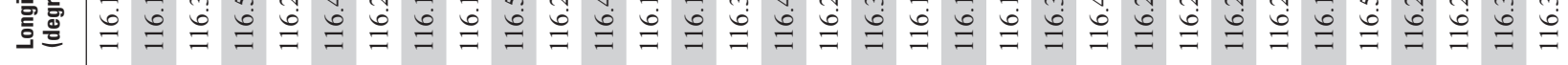

迹

के

근

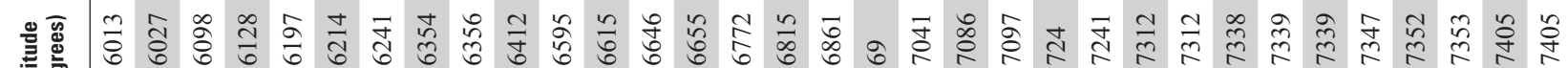

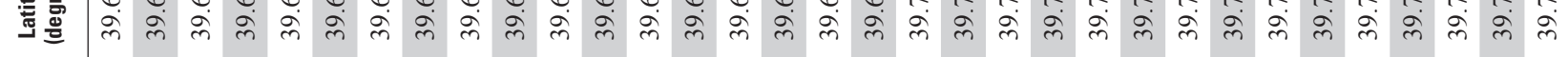

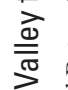

등

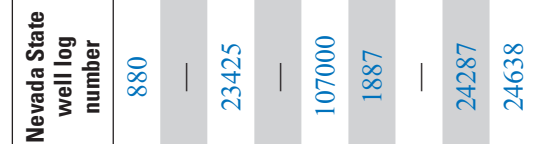

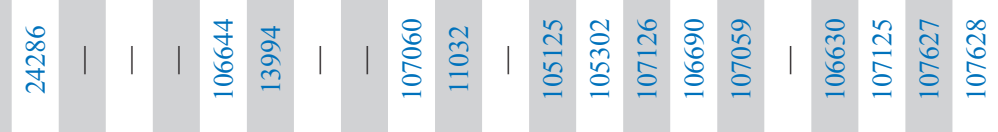
$\frac{\pi}{\square}$

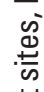

है

売

हृ

京

要

흠

흔

른

总

항

혼

준

ฮั

음

흘

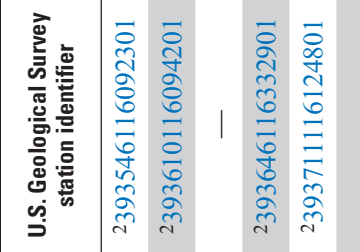

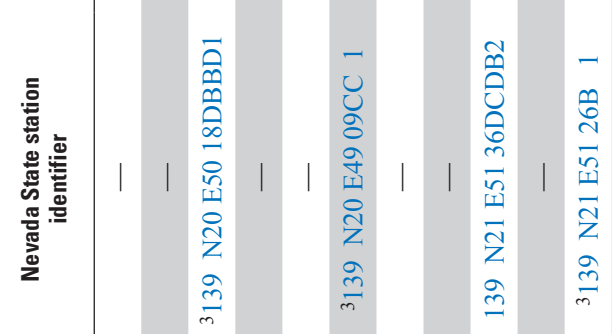
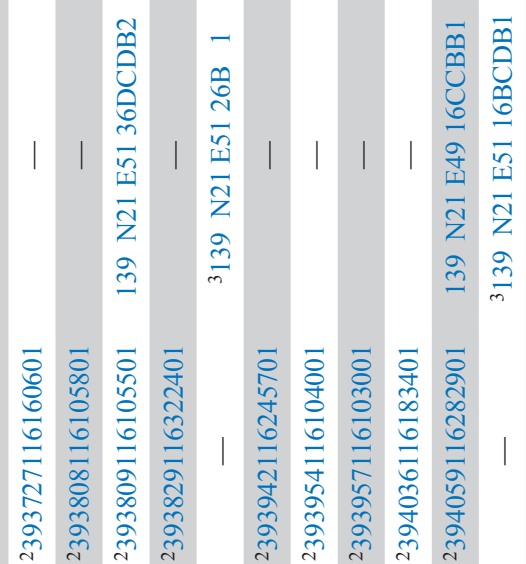

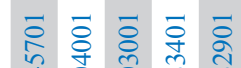

崩

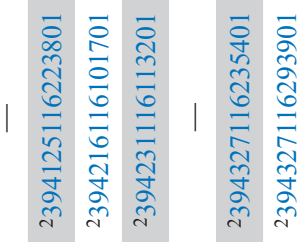

$\overline{\mathrm{z}} \overrightarrow{\mathrm{z}} \overrightarrow{\mathrm{v}} \overline{\mathrm{v}}$

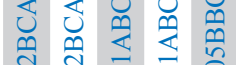

命 ิิ)

摘

ले ले ल ल है

它

స్ల్ల

定

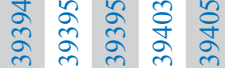

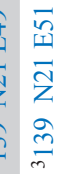

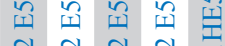

号号品号

$\overline{\mathrm{Z}}$

$\tilde{Z} \tilde{z} \tilde{z} \tilde{z} \bar{z}$

ปี $\tilde{Z} \tilde{z} \tilde{z}$

ले $\vec{m} \underset{m}{m} \stackrel{m}{m} \stackrel{m}{m}$

ले ले

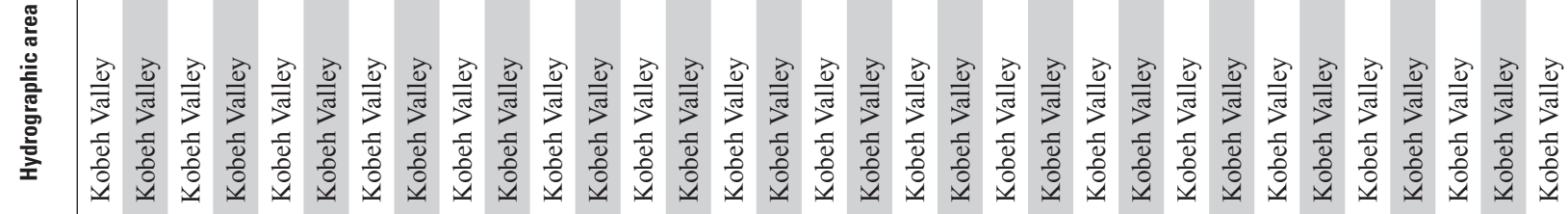

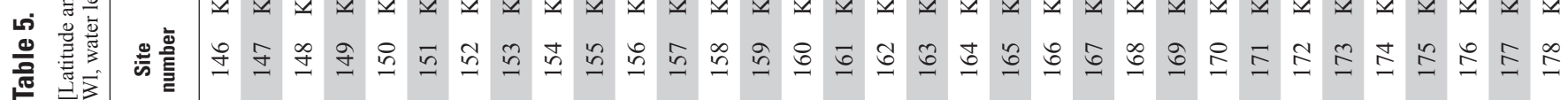




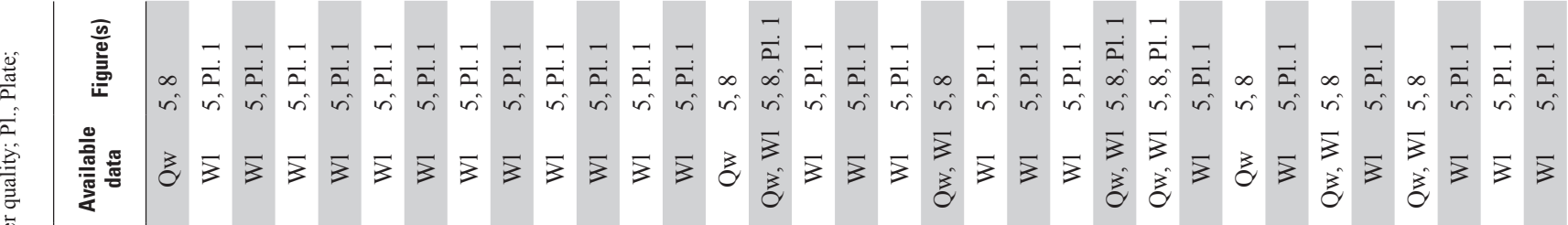

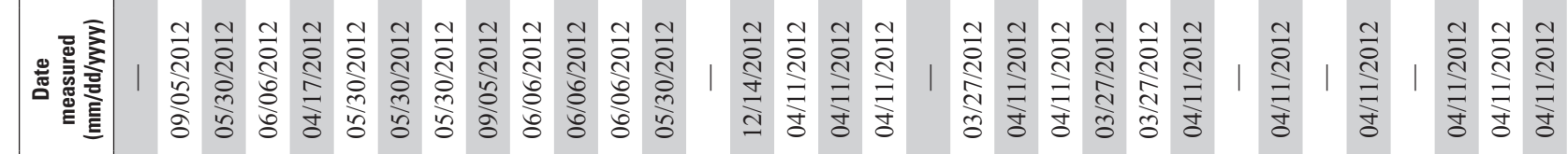

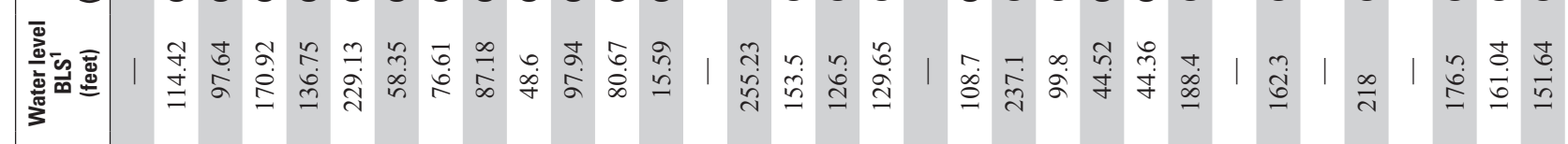

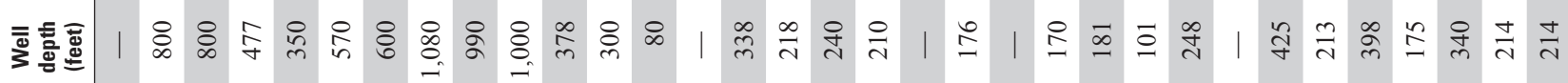

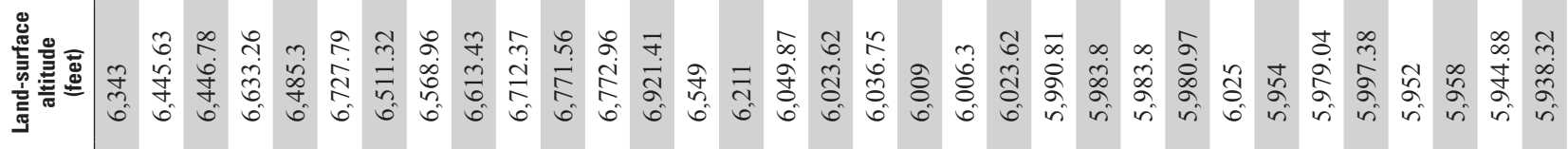

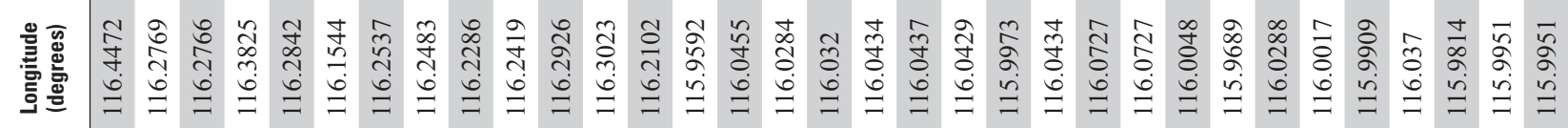

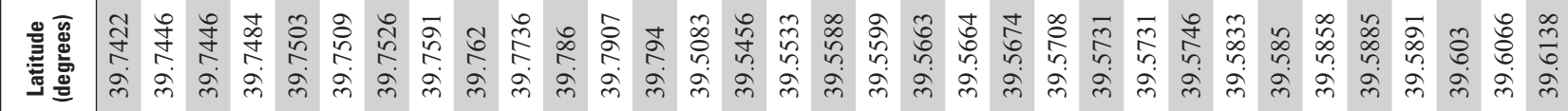

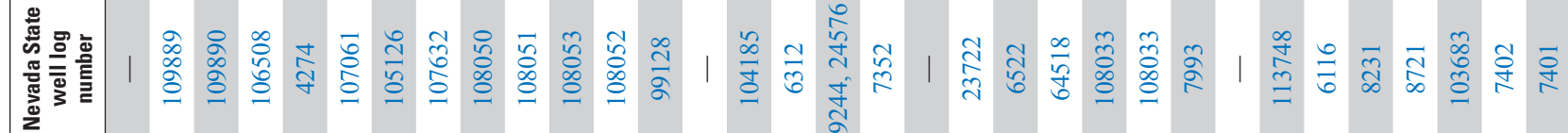
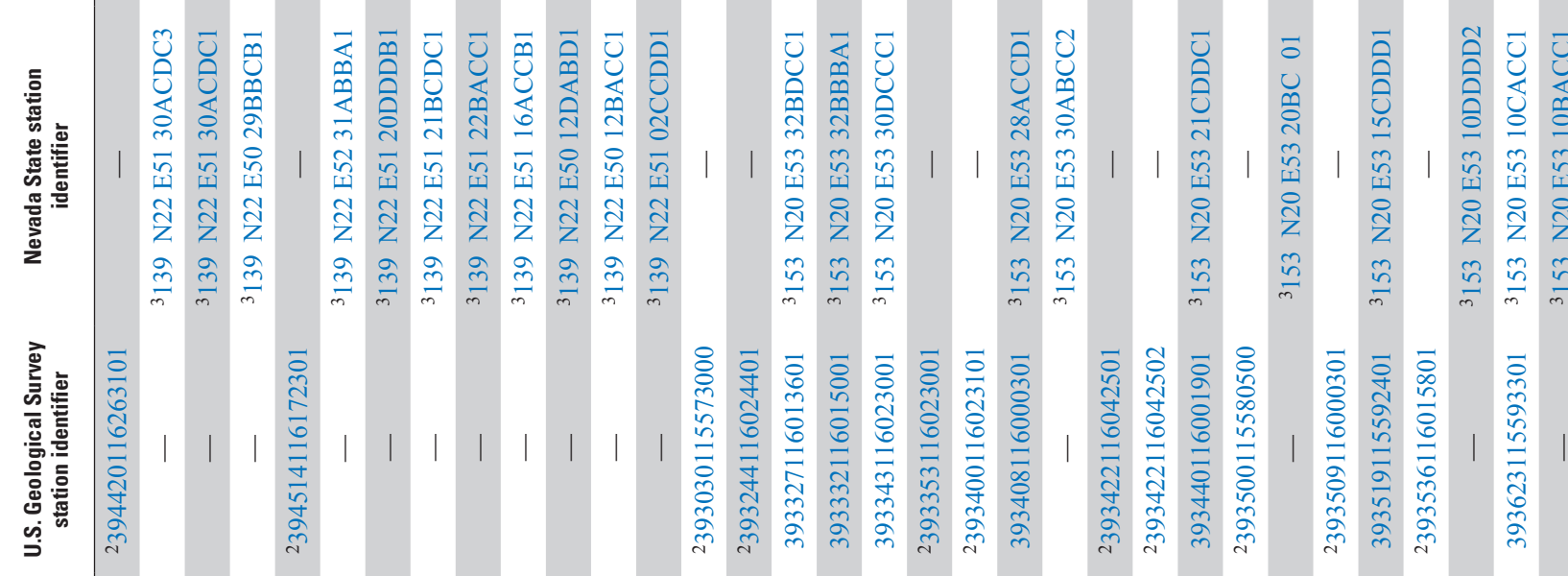

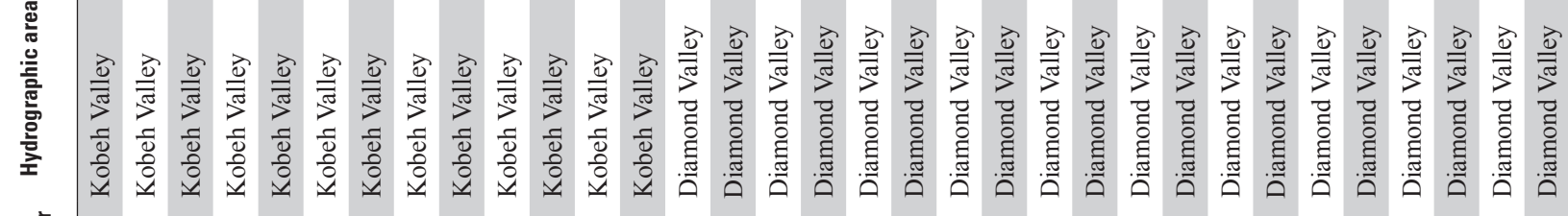

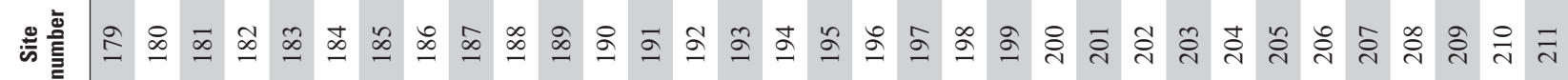


资 定

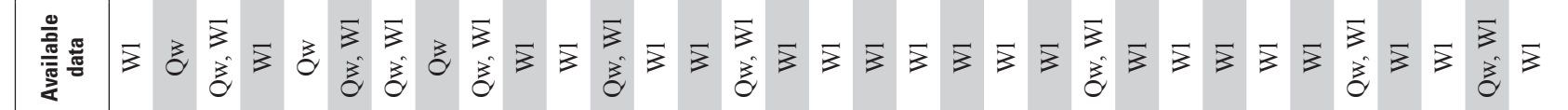

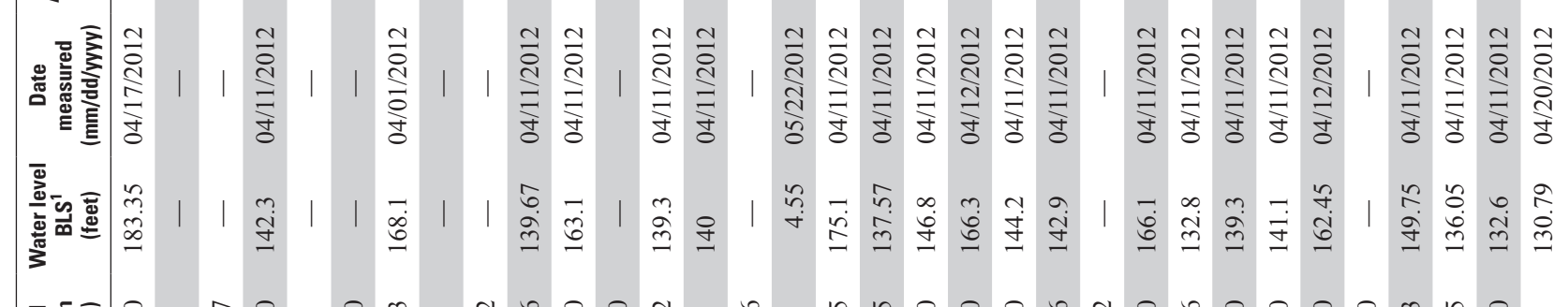

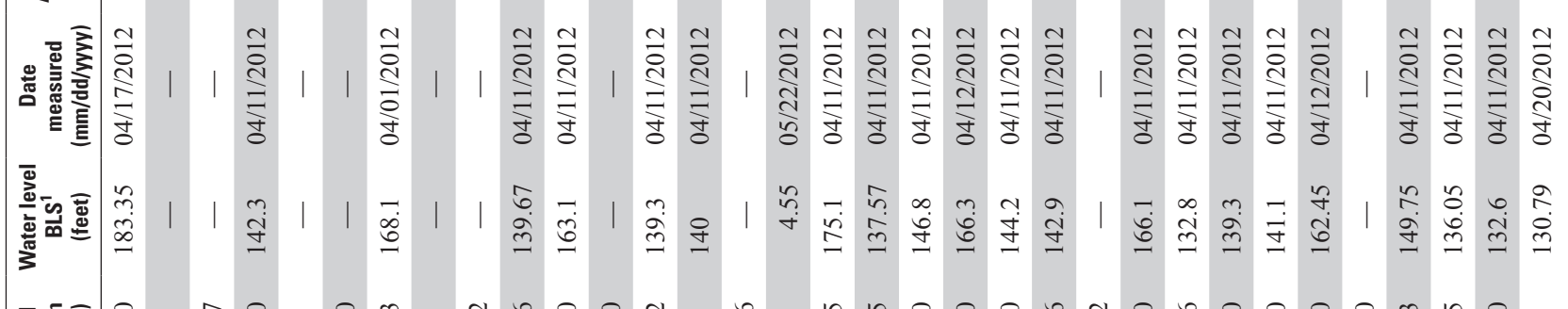

$$
\text { 要 }
$$$$
\text { (1) }
$$$$
\text { 西 }
$$$$
\text { 政 }
$$

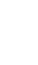$$
\text { to }
$$

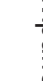$$
\text { 要 }
$$$$
\text { 음 }
$$

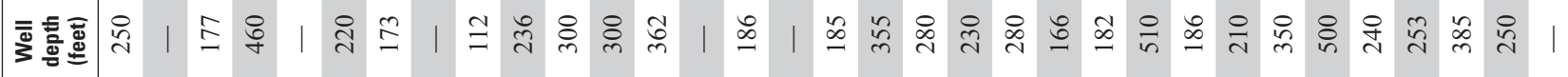

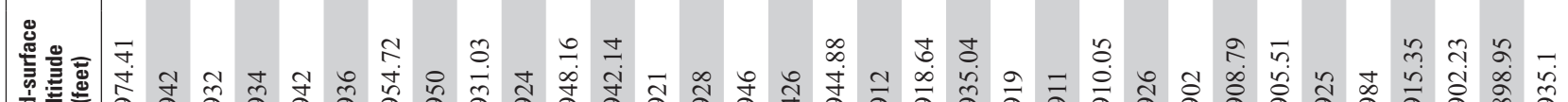

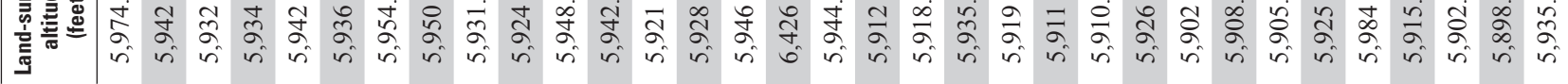

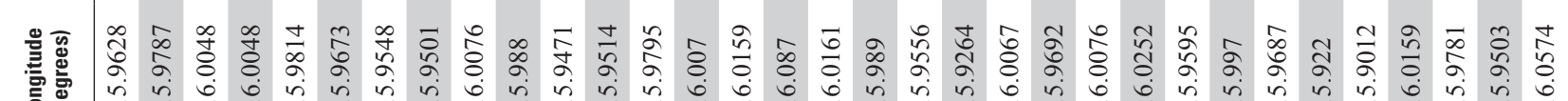

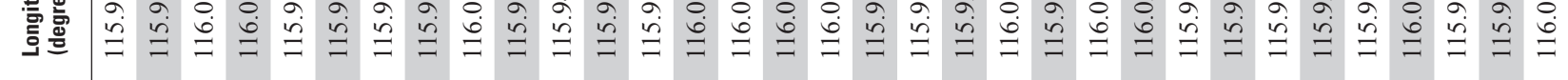

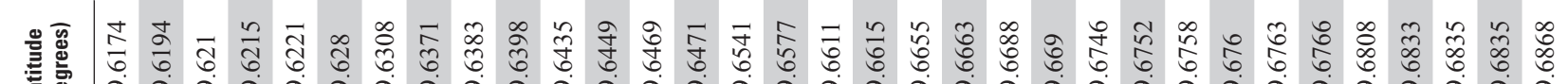

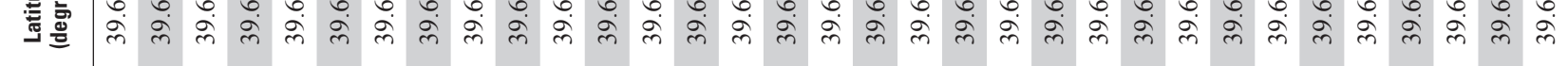

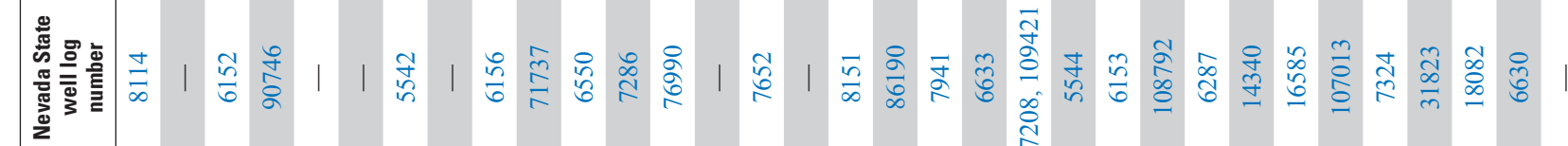

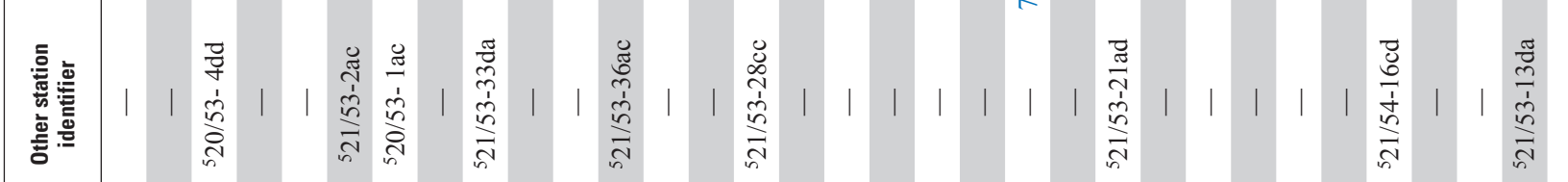

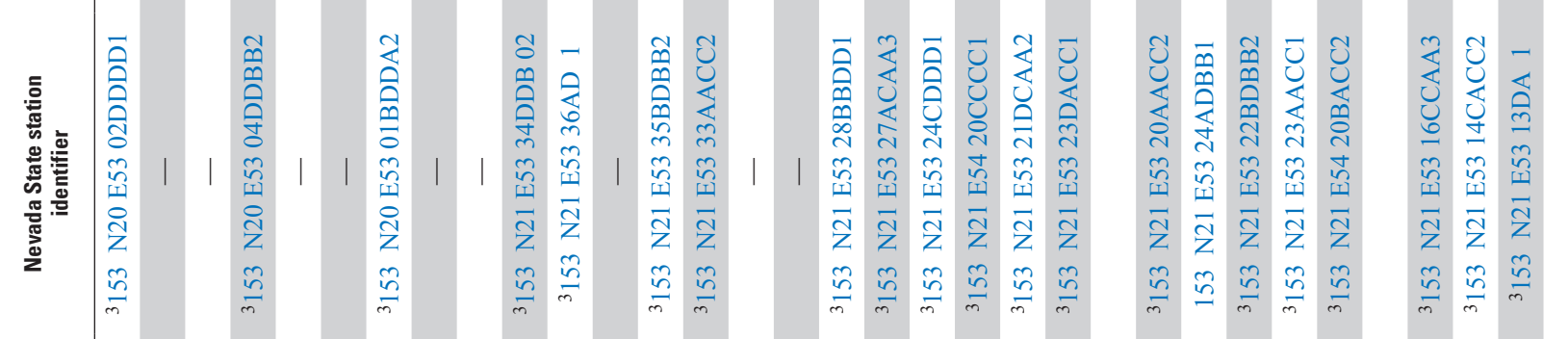

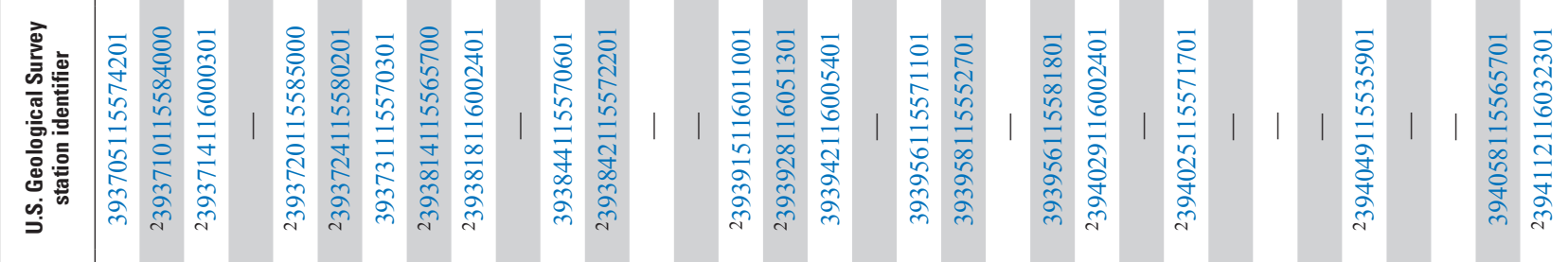

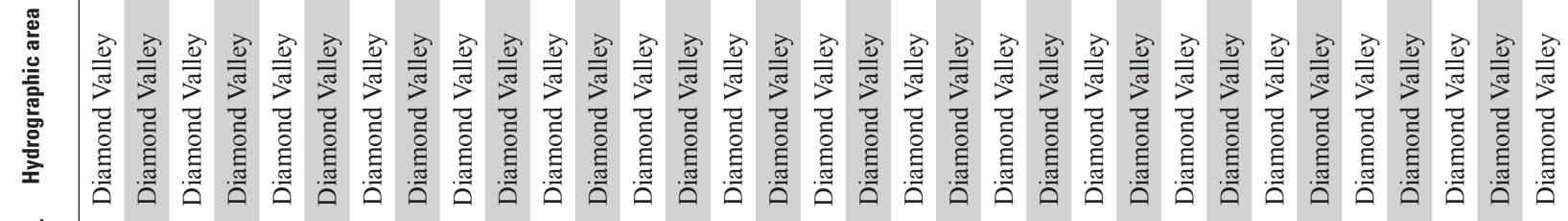

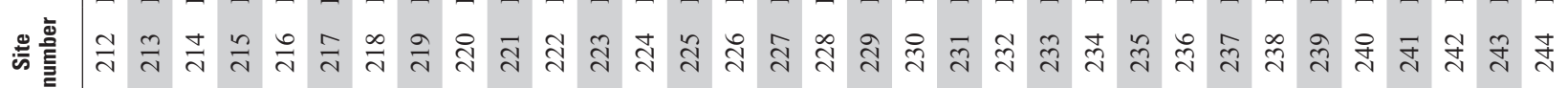

重1

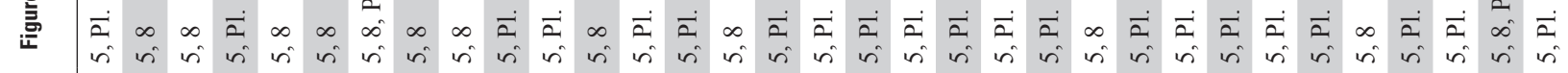




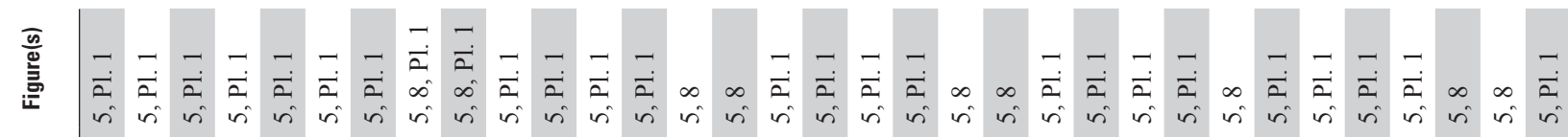
券要要

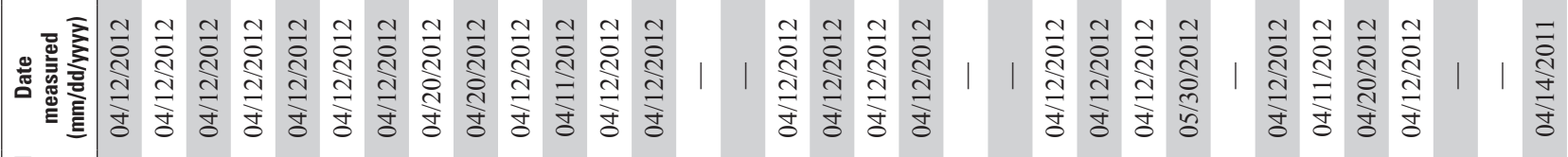

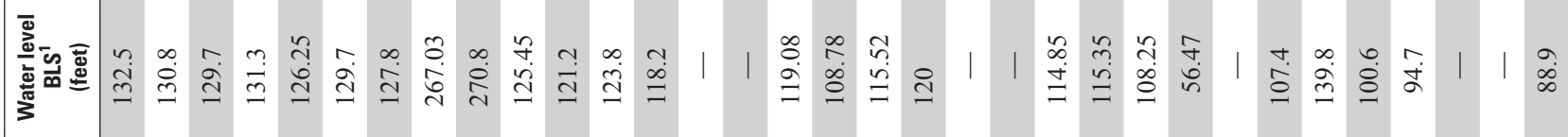
产言要

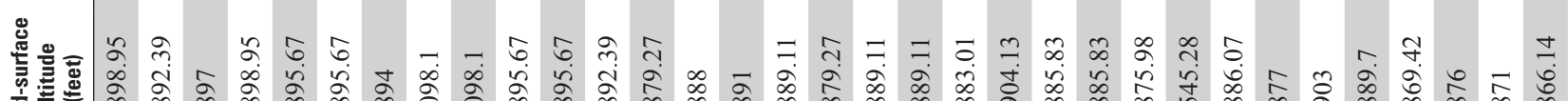

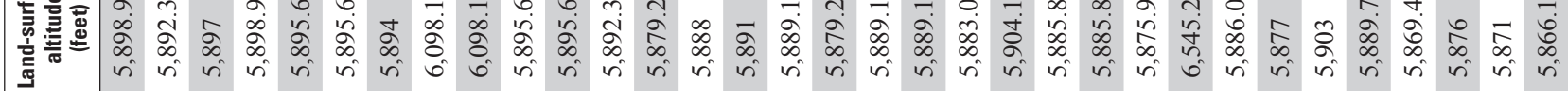

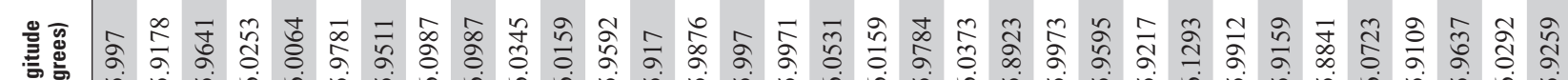

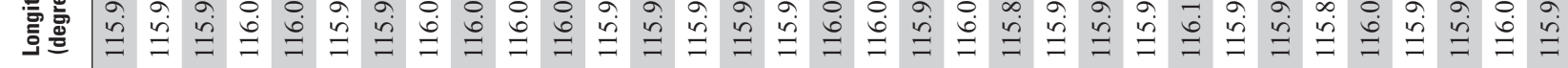

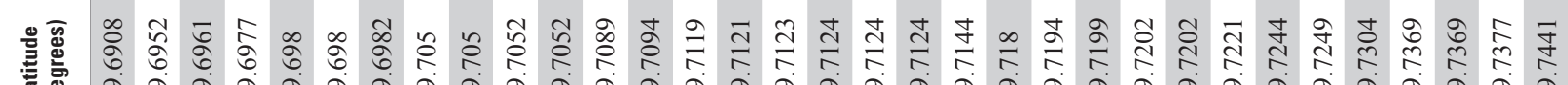

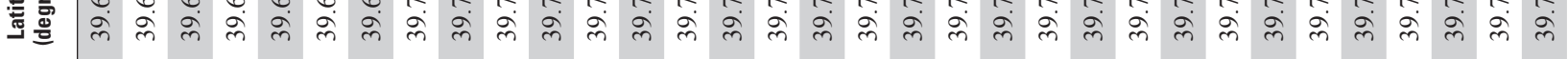

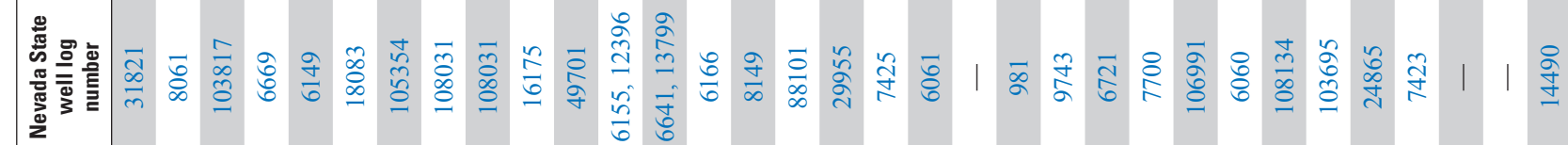

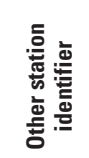
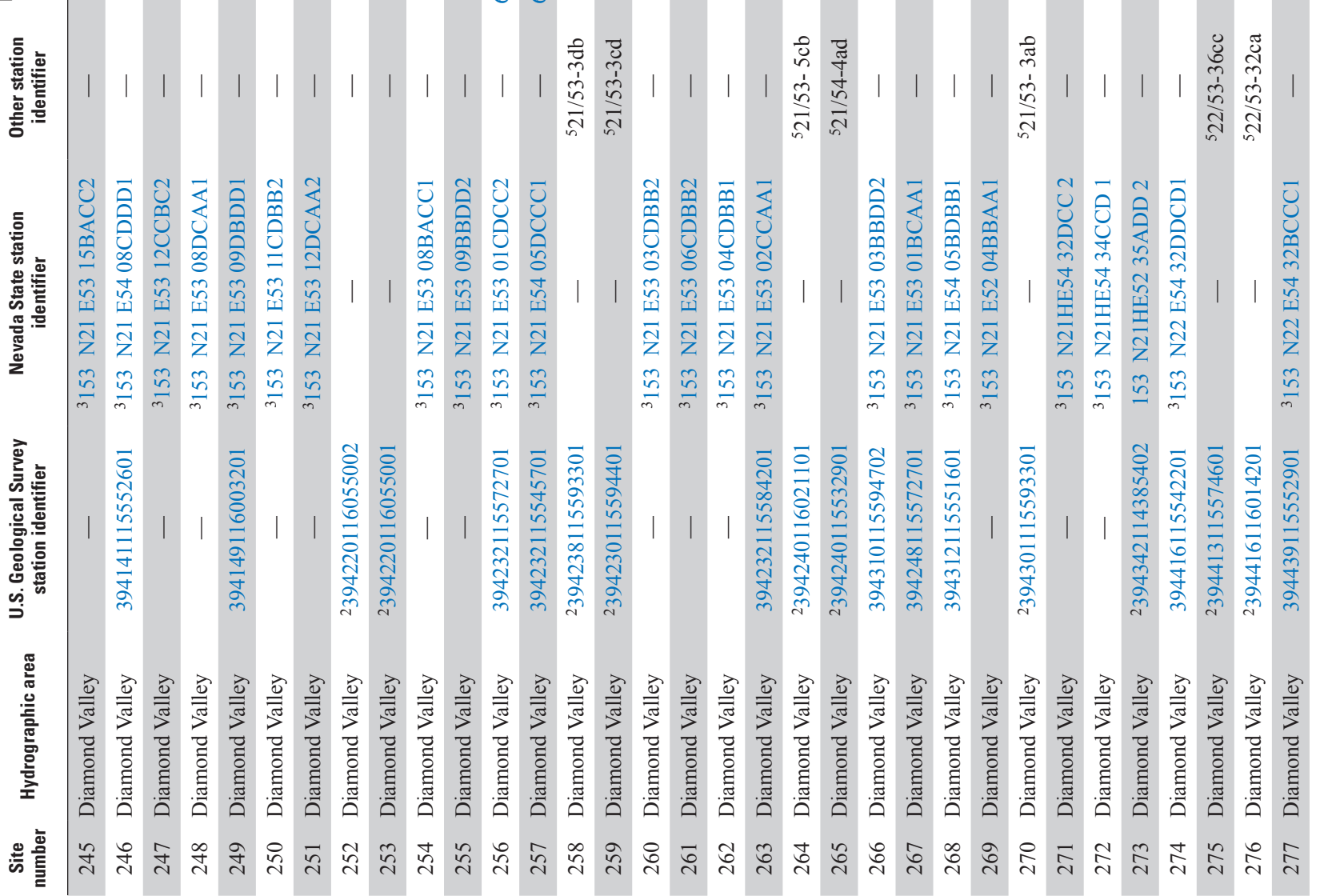


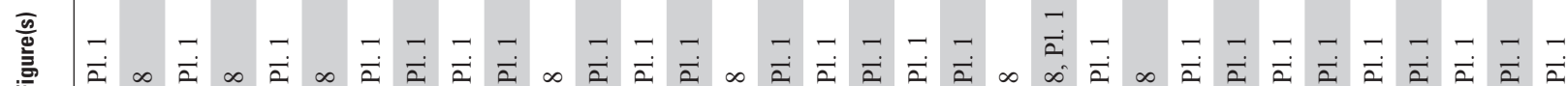

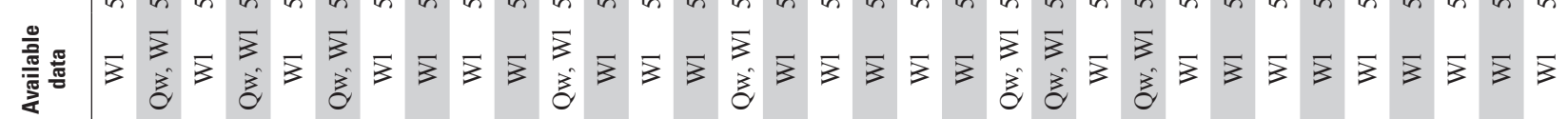

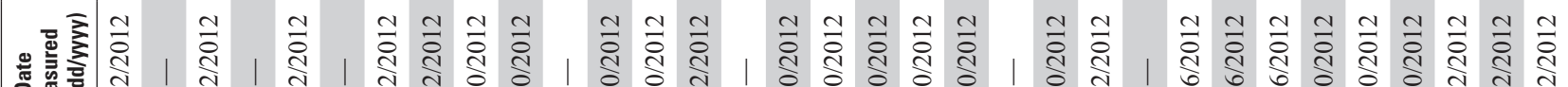

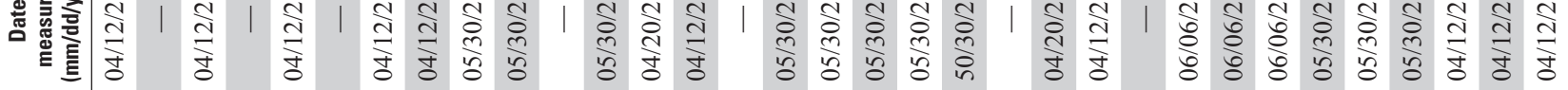

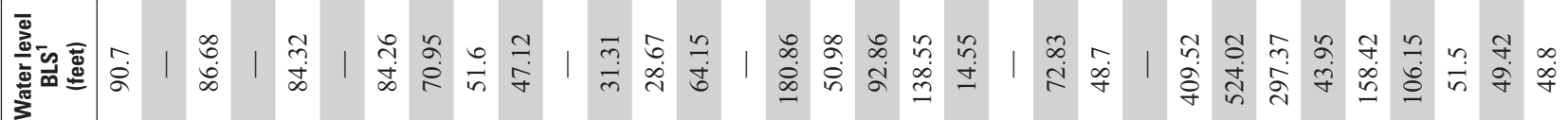

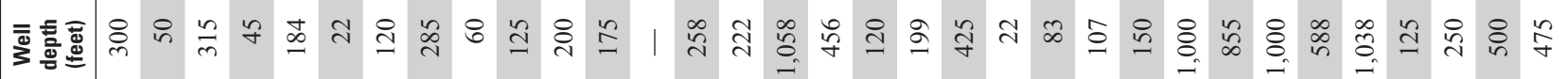

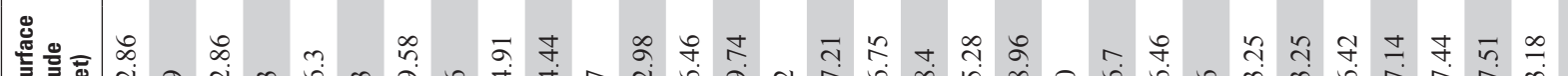

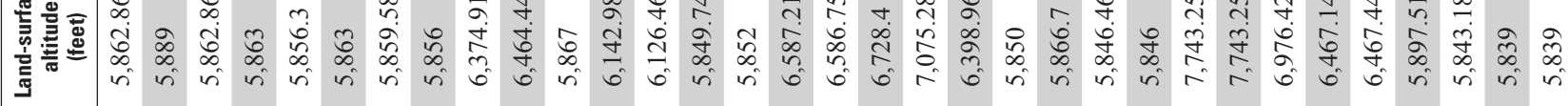

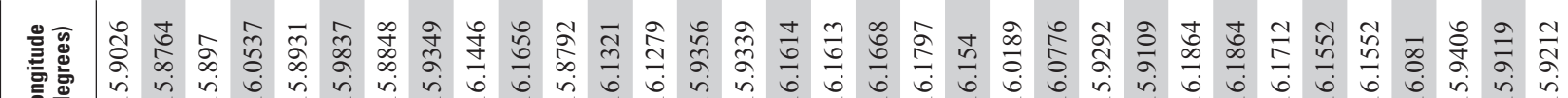

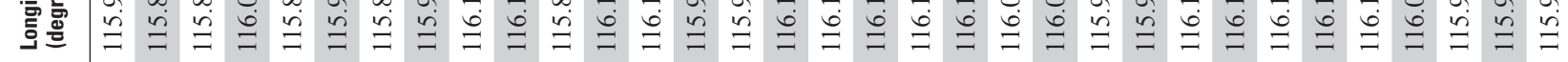

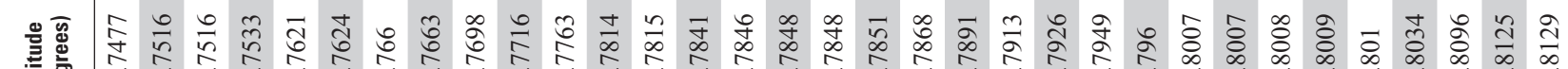

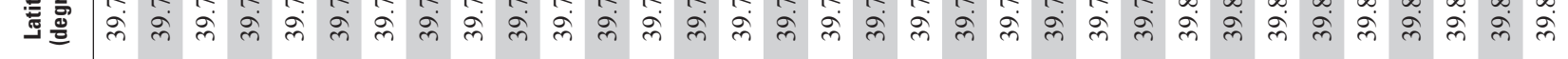

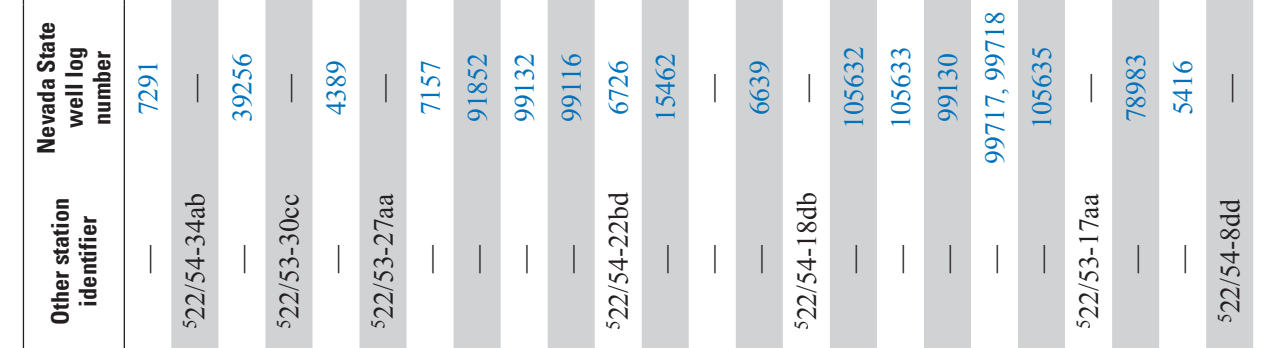
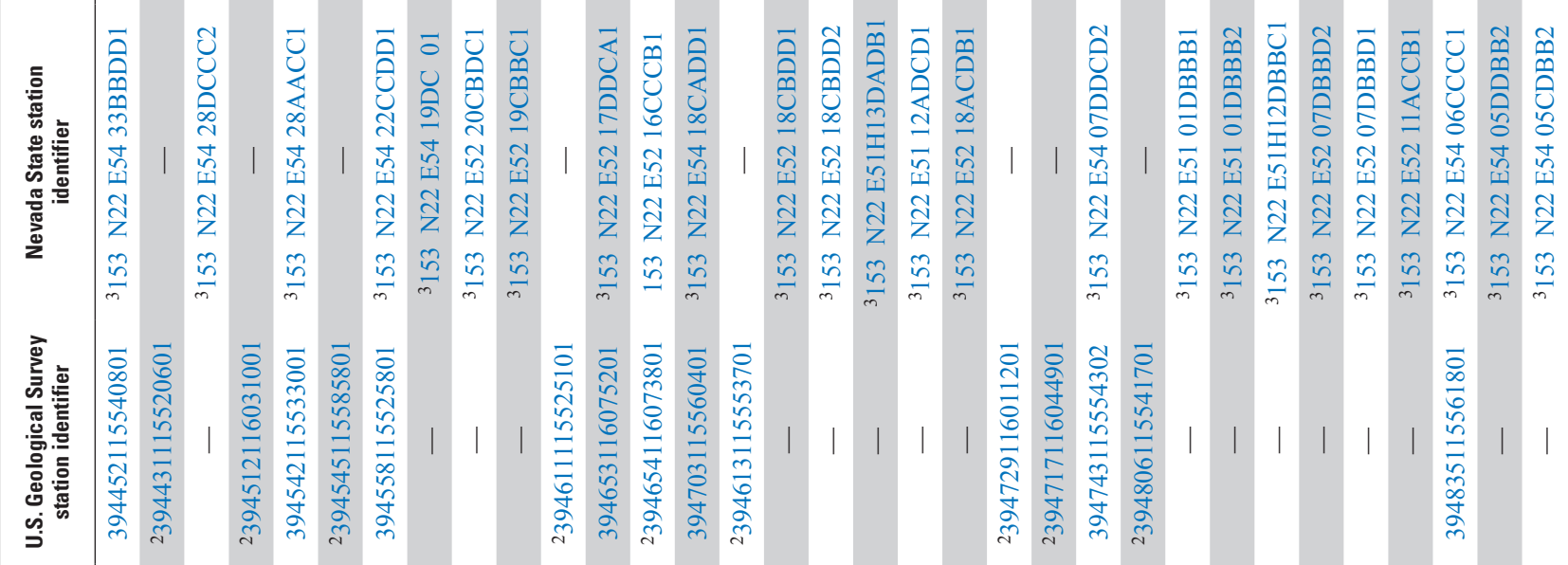

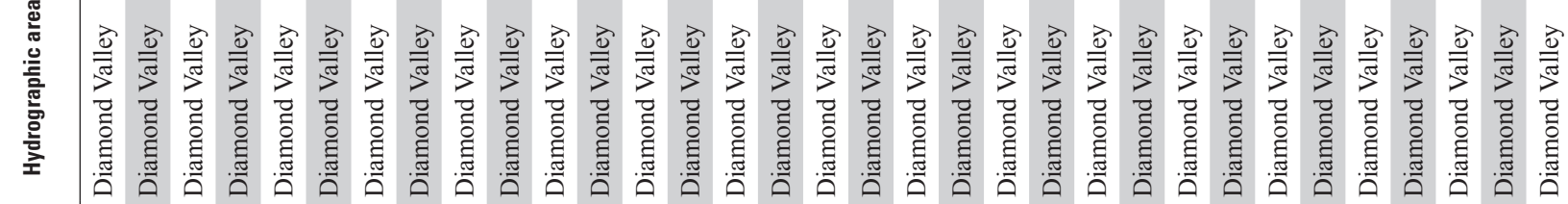

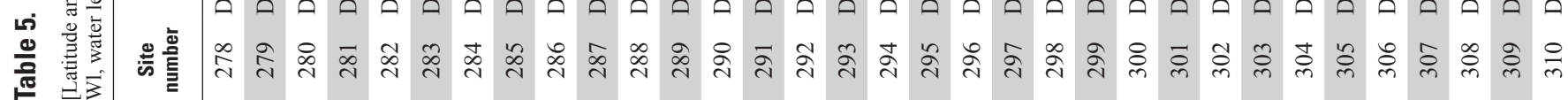




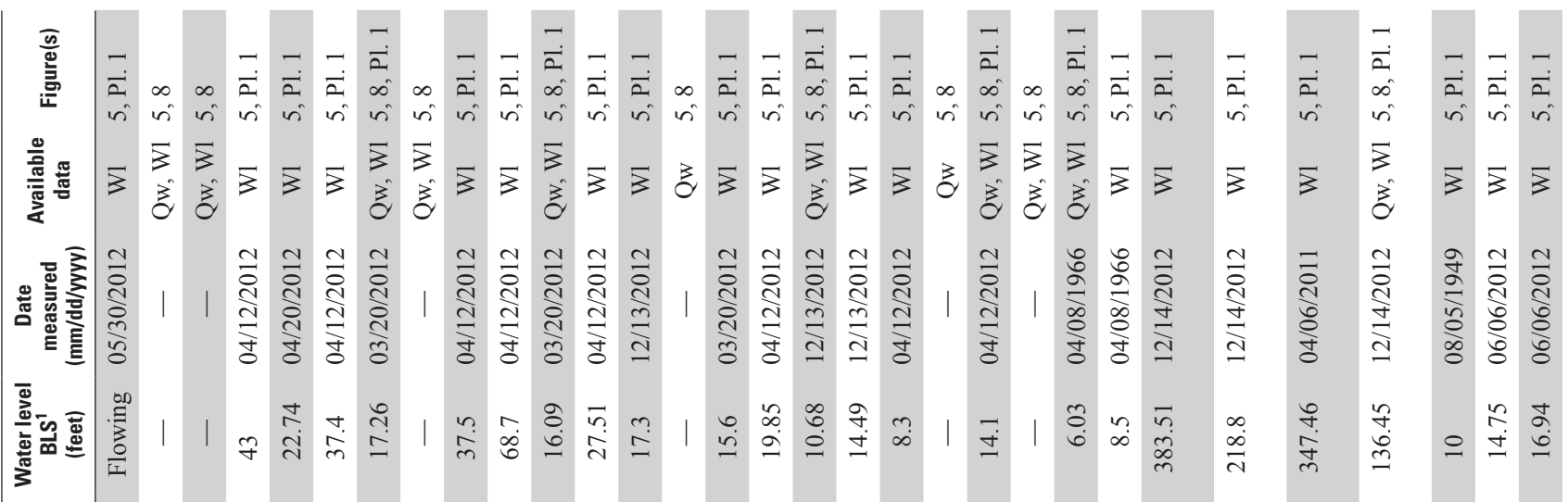

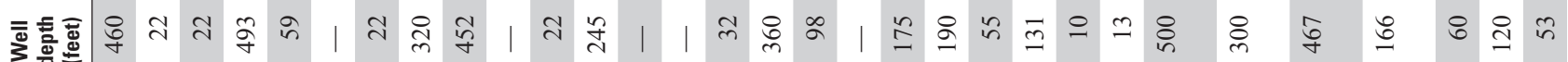

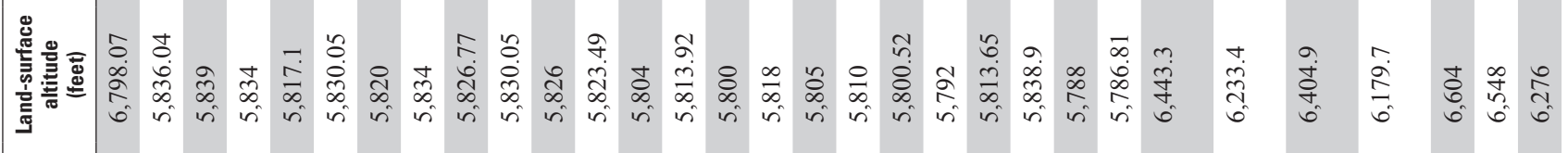

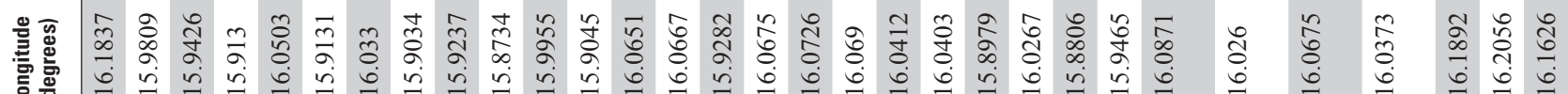
㝘兽 它

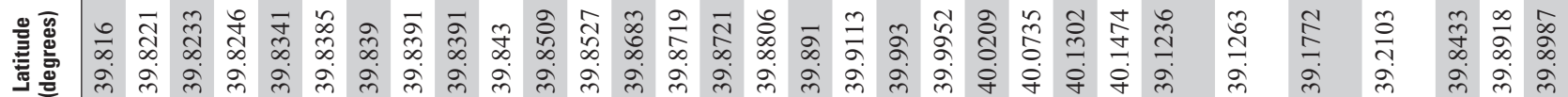

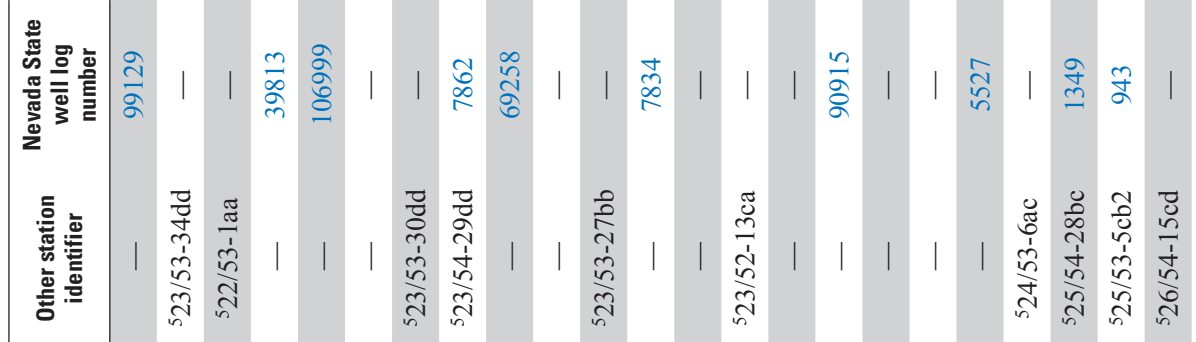
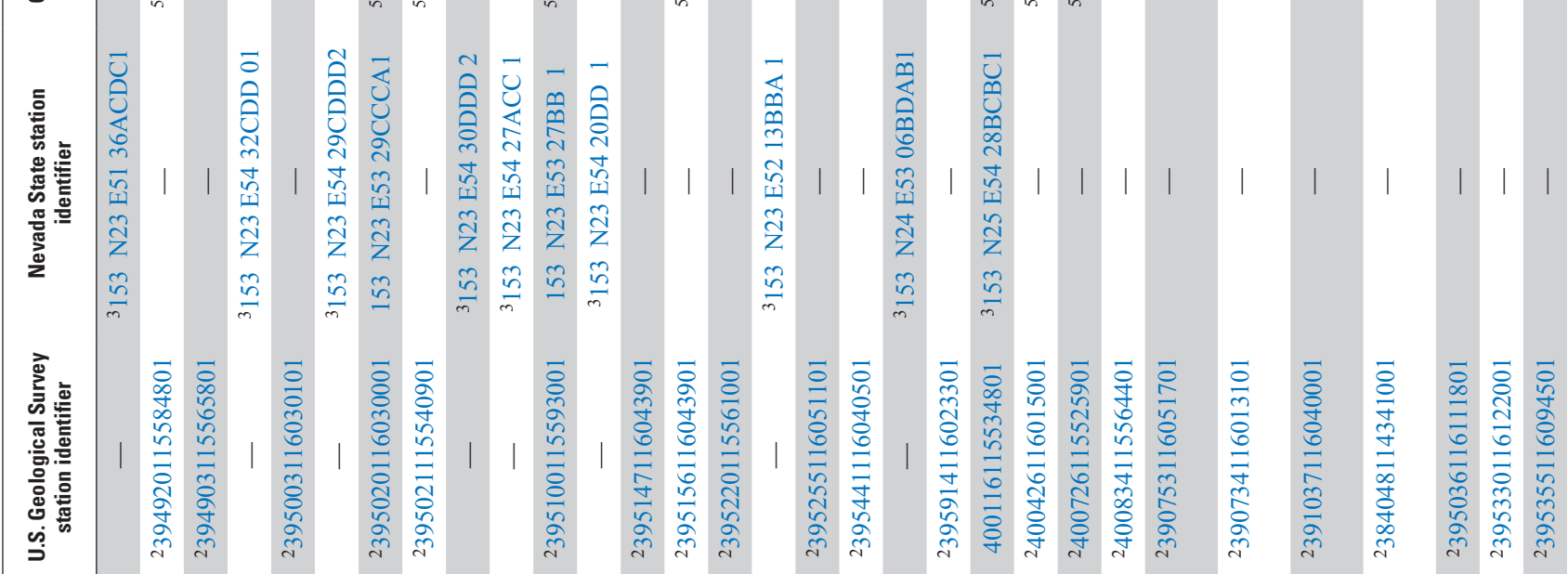

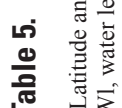

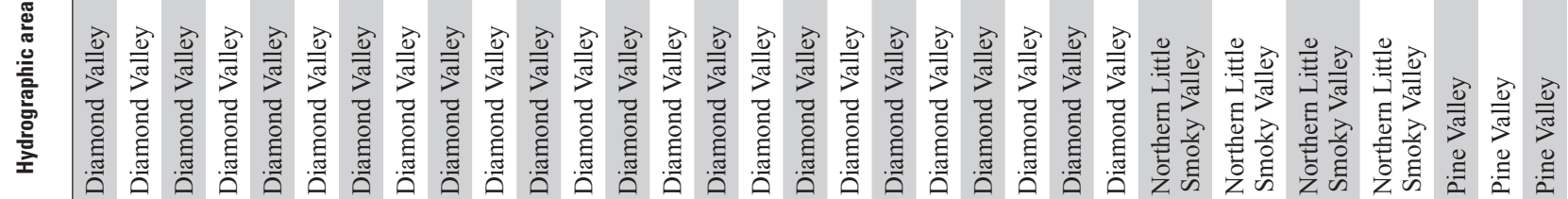

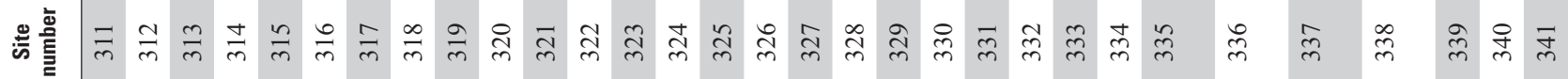




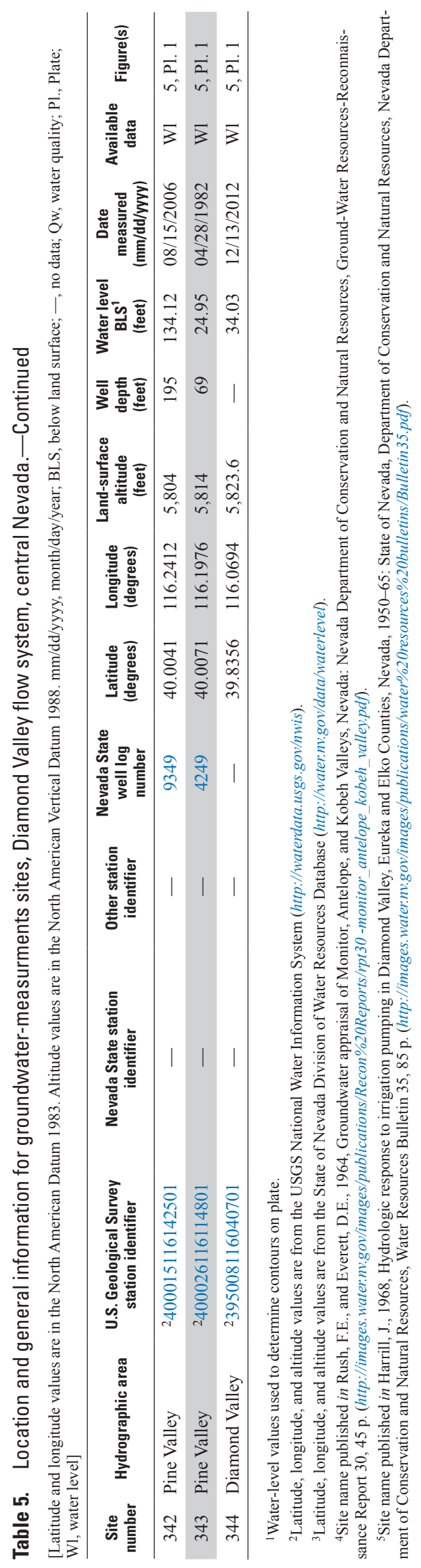


spring complex. With the exception of potential outflow from the southern part of Antelope Valley, groundwater from southern and northern Monitor and Antelope Valleys moves northward toward Kobeh Valley and eastward from Kobeh Valley towards Devil's Gate (plate 1). Devil's Gate is a narrow canyon cut into carbonate rock south of Whistler Mountain and restricts groundwater flow into Diamond Valley. Residual groundwater flow (in excess of that discharged by ET) from valleys upgradient of Diamond Valley converge west of Devil's Gate in Kobeh Valley and flow into the south part of Diamond Valley. Digital Geographic Information System (GIS) data representing the groundwater-level contours shown on plate 1 are described in appendix 1 .

\section{Chemical Characterization of Groundwater}

The chemical composition of groundwater is influenced primarily by the mineral makeup of the hydrogeologic units through which the water flows. Weathering and dissolution of these minerals provides a record in the major-ion chemical composition of groundwater, which can be used to characterize groundwater and evaluate flow paths. Stable isotopes of oxygen-18 and deuterium in precipitation and groundwater also can aid with evaluating the groundwater source and its evolution along a flow path.

Groundwater in basin-fill aquifers in the DVFS was characterized on the basis of water samples from 14 valley springs and from 76 wells representing the upper $250 \mathrm{ft}$ of the aquifer (fig. 8; table 6). All spring and well sites were sampled for major-ion chemistry, and a subset of 32 sites were sampled for stable isotopes. Of the 90 sites sampled, 21 were sampled in 2008 (Knochenmus and others, 2011), and 11 were sampled between late 2010 and 2012. A spring sample from Garden Valley (site 62) and a groundwater sample from Antelope Valley (site 96) were collected in 2008 and again in 2012 (fig. 8; table 6). Major-ions at site 62 were stable between 2008 and 2012 (coefficient of variation within 6 percent), but decreased at site 96 over the same period (coefficient of variation within 36 percent). In addition to groundwater samples, 21 precipitation samples were collected from bulk precipitation collectors co-located with the 4 ET sites (sites 1-4; fig. 2; table 6) and were analyzed for stable isotopes. Appendix 2 provides details about the laboratories used for the chemical analysis and about quality-assurance protocols and analyses used during the 2010-12 sampling events.

To expand spatial coverage in the study area, samples from 60 additional sites reported in previous investigations, the majority of which were in southern Diamond Valley, were incorporated in this analysis (Rush and Everett, 1964; Harrill, 1968; U.S. Geological Survey National Water Information System database (http://waterdata.usgs.gov/nwis). Wellconstruction information related to the sites of these historical samples was often unavailable; therefore, evaluation of chemical gradients between neighboring wells with more recent samples was limited because the different chemical compositions could be related to sampling depth. Sites 125 and 321 in Kobeh Valley and Diamond Valley, respectively, were sampled in the mid-1960s and again in 2008 (table 6), however. Comparisons indicated that most major-ion concentrations from these two sites remained relatively consistent from the mid1960s to 2008 (coefficient of variation within 23 percent) and that the use of older samples in the recent chemical characterization was appropriate. At site 321, an increase in calcium and decrease in sulfate concentrations (coefficient of variation 38 and 77 percent, respectively) was observed between the datasets. Given the extended length of time between collecting the sample, it is unclear if the changes in calcium and sulfate are valid, or if sampling, analytical laboratory techniques, or both could have contributed to the differences. Groundwater pumping also has caused substantial groundwater-level declines in areas near many of the historical water-chemistry sampling sites in southern Diamond Valley; however, the 1960s data provide the best water-chemistry dataset available for the area.

\section{Major-Ion Chemistry}

The chemical signature of groundwater reflects general hydrogeologic-unit mineralogy and can be used to infer groundwater flow paths. In the DVFS, major-ion chemistry was used to group groundwater samples into water types and to evaluate groundwater evolution. Groundwater samples collected from sites 62,126 , and 160 were not evaluated for bicarbonate concentrations by the analytical laboratory (table 6); therefore, bicarbonate alkalinity (converted from the alkalinity concentration of calcium carbonate in milligrams per liter, or $\mathrm{mg} / \mathrm{L}, \mathrm{CaCO}_{3}$, assuming the concentration was entirely bicarbonate; table 8 in Hem, 1985) was used for anion comparisons. The cation chemistry of natural waters typically is dominated by calcium, magnesium, sodium, and potassium (Hem, 1985). The chemistry of water samples collected as part of this study is summarized in figure 9. The majority of samples (roughly 90 percent) consisted of 10 to 80 percent calcium; 15 to 90 percent sodium, with little potassium present relative to sodium; and 10 to 60 percent magnesium. There was greater variability in cation chemistry in Diamond, Kobeh, and southern Monitor Valleys than northern Monitor and Antelope Valleys (fig. 9). The anion chemistry of most samples collected as part of this study consisted of 60 to 90 percent bicarbonate, 5 to 35 percent sulfate, and 5 to 40 percent chloride. Calcium-bicarbonate water type was represented in 58 percent of samples, sodium-bicarbonate in 22 percent of samples, and magnesium-bicarbonate in 11 percent of samples (fig. 9). Anion chemistry was dominated by bicarbonate in all water samples collected, with a few noted exceptions; sites 46, 252, 253, 218, and 74 were dominated by sulfate in areas down gradient of siliciclastic sedimentary rocks (sulfate-bearing), while sites 298, 312, and 317 were dominated by chloride near the Diamond Valley playa (flow system terminus). No clear differences were observed in the general water types of the individual basins. 
Carbonate rocks are composed of various calcium-carbonate minerals and are present in most mountain ranges in the DVFS, predominately, in the Diamond Mountains and the Sulphur Springs, Fish Creek, and Antelope Ranges (fig. 8; Tumbush and Plume, 2006). Accordingly, the majority of groundwater samples from central and southern Diamond, Antelope, northern Little Smoky Valley, southern and northern Monitor Valleys, and northern Kobeh Valley were a calciumbicarbonate type (figs. 8, 9). Groundwater samples from throughout southern Kobeh Valley, central Diamond Valley, and southern Monitor Valley were a sodium-bicarbonate type. Greater sodium proportions in southern Kobeh Valley and southern Monitor Valley groundwater (sites 70, 119, 121, 125, 126, 132; figs. 8, 9; table 6) likely resulted from plagioclaserich andesitic and ash-flow tuff volcanic rocks present in the recharge source areas in the Simpson Park Mountains and the Toquima and northern Monitor Ranges (fig. 1; Roberts and others, 1967). Sulfate water types with various cation proportions were found in the northern part of southern Monitor Valley (site 74; figs. 8, 9; table 6), the western part of Kobeh Valley (site 46; figs. 8, 9; table 6), and west-central Diamond Valley (sites 252 and 253; figs. 8, 9; table 6). The source of sulfate is probably related to clastic rocks consisting of black shale of the Vinnini Formation (Roberts and others, 1967).

The chemical signature of groundwater in Diamond Valley largely was determined from samples collected in the mid1960s by Harrill (1968) and indicated changes in water type along groundwater-flow paths. Groundwater near valley edges generally was calcium- or magnesium-dominated bicarbonate water (fig. 8) with slightly elevated (compared to $500 \mathrm{mg} / \mathrm{L}$ secondary drinking water standard) total dissolved solids concentrations (TDS; $338 \mathrm{mg} / \mathrm{L}$ average, table 7). During pre-development and at least through the 1960s, groundwater generally flowed from southern to northern Diamond Valley, discharging near the large playa (Harrill, 1968). Groundwater in playa deposits was documented as chemically distinct from that in the fresh basin-fill aquifer (Huntington and others, 2014). As would be expected at the terminus of a groundwater-flow system, sodium and chloride content increased from averages of 32 and $24 \mathrm{mg} / \mathrm{L}$, respectively, near southern Diamond Valley to about $340 \mathrm{mg} / \mathrm{L}$ (table 7) near the southern playa edge because of continued enrichment as groundwater moved along this northerly flow path toward the playa. The groundwater evolved from a calcium-bicarbonate to a sodium-bicarbonate to a more concentrated sodium-chloride water (sites 298, 312, and 317 from figs. 8, 9; table 6; similar to Arakel and others, 1990), likely owing to ion exchange of calcium for sodium and the release of sodium bound in clays in basin-fill deposits (Harrill, 1968). The post-development groundwater divide, near sites 317 and 321, has caused a reversal of the direction of groundwater flow, which eventually can result in the southward migration of higher TDS and sodium-rich groundwater.

Groundwater in the DVFS was evaluated with respect to national primary and secondary drinking-water standards. Primary standards (maximum contaminant levels, or MCLs) have been established by the U.S. Environmental Protection Agency (EPA) for constituents that pose potential health risks to humans (U.S. Environmental Protection Agency, 2009). Secondary standards generally are non-enforceable guidelines designed to ensure water quality with desirable cosmetic or aesthetic characteristics, such as taste and odor (U.S. Environmental Protection Agency, 2009); however, the Nevada Division of Environmental Projection enforces Nevada-specific secondary standards (Nevada Administrative Code 445A.455).

Groundwater quality in the DVFS generally was within acceptable drinking water standards, with only a few exceptions. The $\mathrm{pH}$ was measured outside the acceptable range (6.6-8.5) in three samples; Diamond and Kobeh Valleys each contained one sample above 8.5 and Southern Monitor Valley contained one sample below 6.5 (table 6). The secondary MCL for chloride and sulfate (both $250 \mathrm{mg} / \mathrm{L}$ ) was exceeded in three and six samples, respectively (table 6). Chloride exceedances occurred only within Diamond Valley whereas sulfate exceedances occurred in Diamond (4), Southern Monitor (1) and Kobeh Valleys (1). Total dissolved solids concentrations ranged from 77 to $1,520 \mathrm{mg} / \mathrm{L}$, with a median concentration of $320 \mathrm{mg} / \mathrm{L}$. Concentrations in nine samples, seven of which were collected in Diamond Valley, exceeded the 500 $\mathrm{mg} / \mathrm{L}$ TDS secondary MCL. No samples exceeded the natural fluoride MCL of $4 \mathrm{mg} / \mathrm{L}$; however, samples from two sites in Kobeh Valley exceeded the Nevada secondary MCL of $2 \mathrm{mg} / \mathrm{L}$.

\section{Stable Isotopes}

Stable isotope data were used to gain insight about precipitation distributions, the source and timing of groundwater recharge, and interbasin flow beyond the DVFS. The stable isotopes of oxygen-18 and deuterium in water are affected by meteorological processes and exhibit a strong correlation with air temperature (Friedman, 1953). A global meteoric water line (GMWL; Craig, 1961) represents the relationship between oxygen-18 and deuterium of fresh water on a global scale and provides a reference for interpreting isotopic data of groundwater. Craig (1961) observed that isotopically depleted groundwater (more negative values) was associated with cool temperatures, whereas isotopically enriched groundwater (less negative values) was associated with warm temperatures. From this correlation, the source and season of groundwater recharge can be evaluated.

Stable isotope data were collected from well and spring sites throughout the DVFS (1981, 2008, and 2012) and were compared to isotope data from local precipitation (table 6). Precipitation was sampled for isotopic analysis from bulkprecipitation gages in 2012 and early 2013 during warm (July, Aug., and Sept.) and cool months (Oct., Nov., and Feb.). Bulkprecipitation gages collocated at ET sites in Kobeh Valley were filled with at least one-half inch of mineral oil to minimize evaporative losses. Isotopic signatures of locally sampled precipitation were used to define a local meteoric water line (LMWL; fig. 10). 


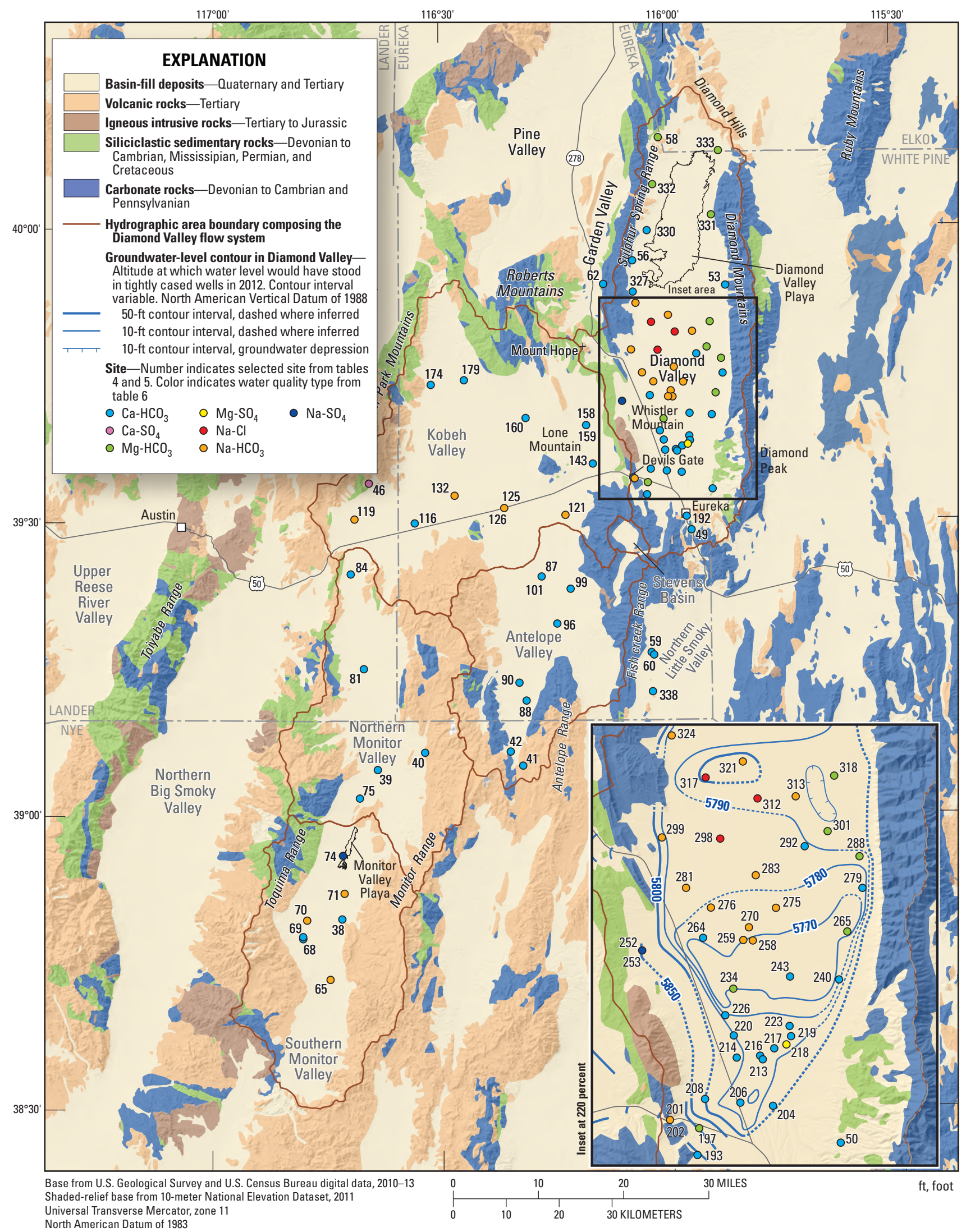

Figure 8. Geology, groundwater-level contours, and sites sampled for groundwater chemistry and chemical typing, Diamond Valley flow system and adjacent basins, central Nevada, 1954-2012. 


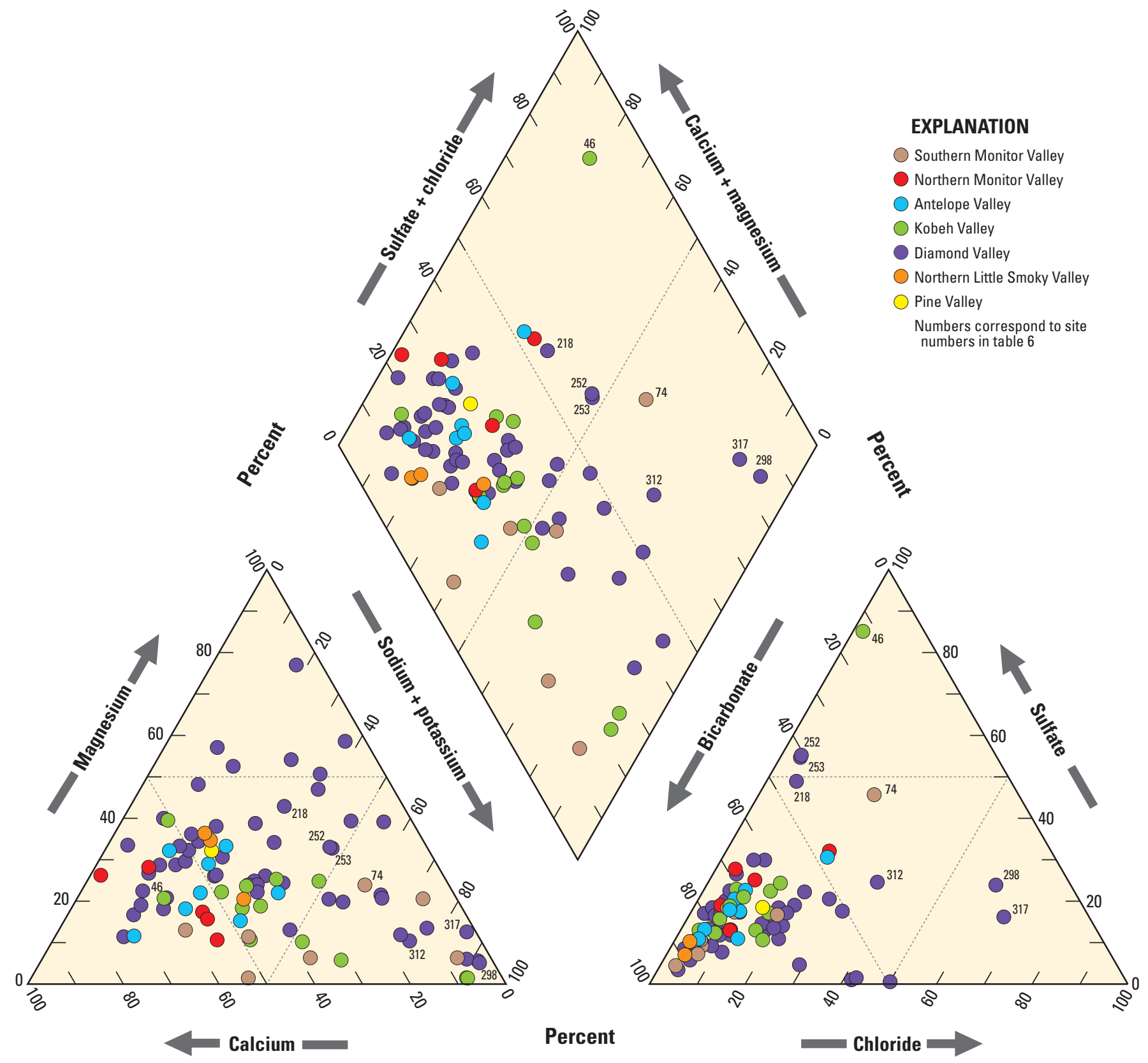

Figure 9. Chemical type of groundwater in the Diamond Valley flow system, central Nevada. Relative concentrations of cations and anions are presented in the lower left and right triangles, respectively; relative concentrations are projected onto the central diamond to illustrate the combined major-ion chemistry. 


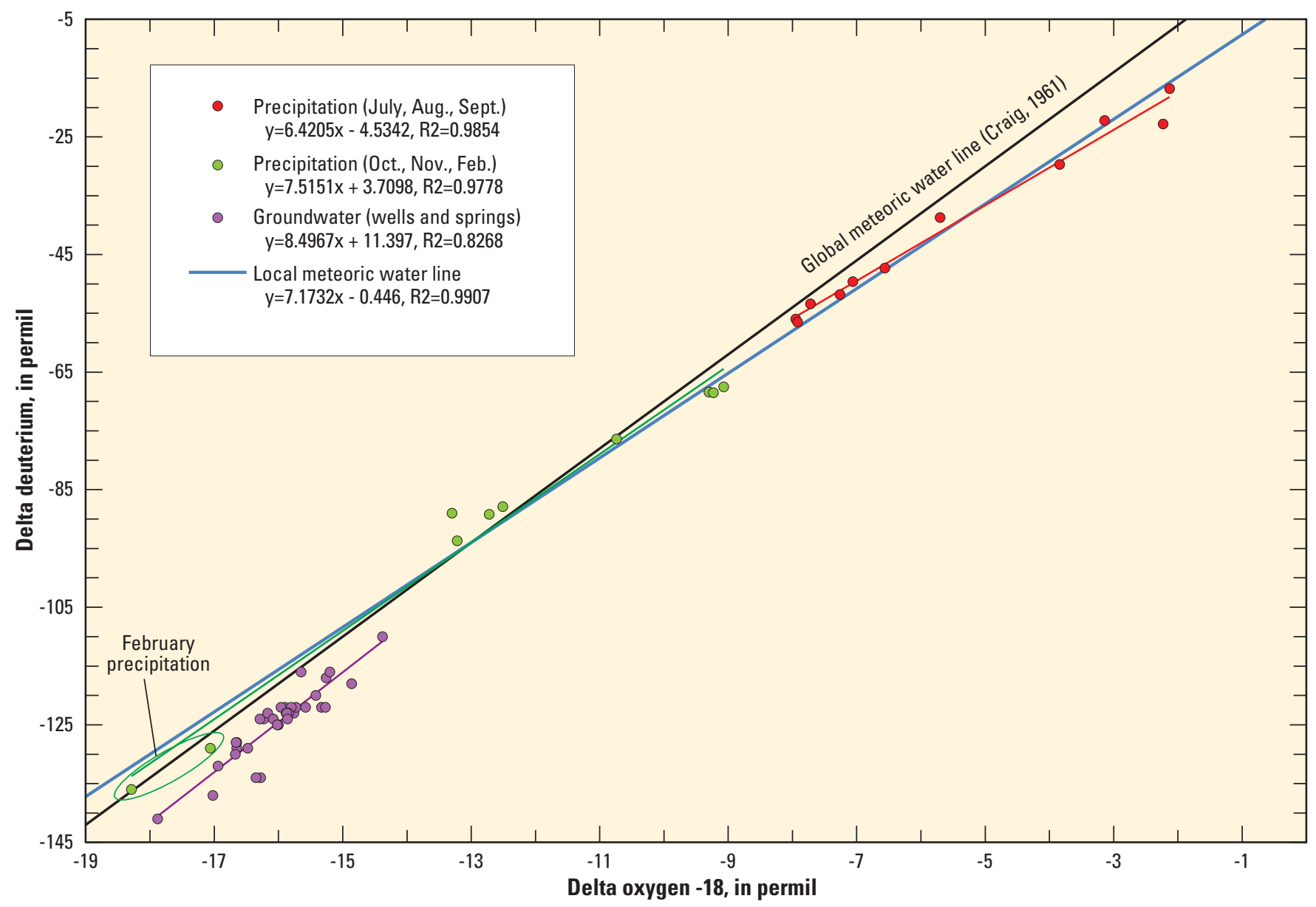

Figure 10. Relation between oxygen-18 and deuterium for precipitation, groundwater, and spring water samples, Diamond Valley flow system and adjacent valleys, central Nevada. 
Generally, the LMWL indicated precipitation that falls in the DVFS was isotopically similar to the GMWL, with only slight evaporative enrichment during the warmer months, as evidenced by the shallower slope in those data (fig. 10). Precipitation data collected in warmer months in the DVFS exhibited a seasonal variation due to evaporation when compared with samples collected during cooler months. The trend line defined by warmer temperature data exhibited a shallower slope than either the GMWL or the trend line defined by the cooler temperature data. The isotopic signature from coolmonth data was comparable to the GMWL.

Most groundwater signatures (including springs) are similar to cool-season precipitation but slightly enriched in oxygen-18 compared to the GMWL and the LMWL (fig. 10). Similar signatures among groundwater and cool-season precipitation indicates that groundwater is, in part, derived from cool-season precipitation under current climate conditions.
The slight enrichment in oxygen-18 relative to deuterium could reflect groundwater interaction with warmer waters along deep flow paths (Drever, 1988, Clark and Fritz, 1997). Increased temperature can increase the solubility of minerals and cause a shift in oxygen-18 (Palmer and Cherry, 1984; Thomas and others, 1996).

Isotopic and major-ion data collected from Fish Creek Springs water in northern Little Smoky Valley were compared to isotopic and major-ion data collected from wells in southern Antelope Valley to assess interbasin flow. Although groundwater-level altitudes in southern Antelope Valley indicated the potential for flow toward northern Little Smoky Valley, the isotopic and major-ion data were inconclusive, and therefore could not be used to support this inference. 


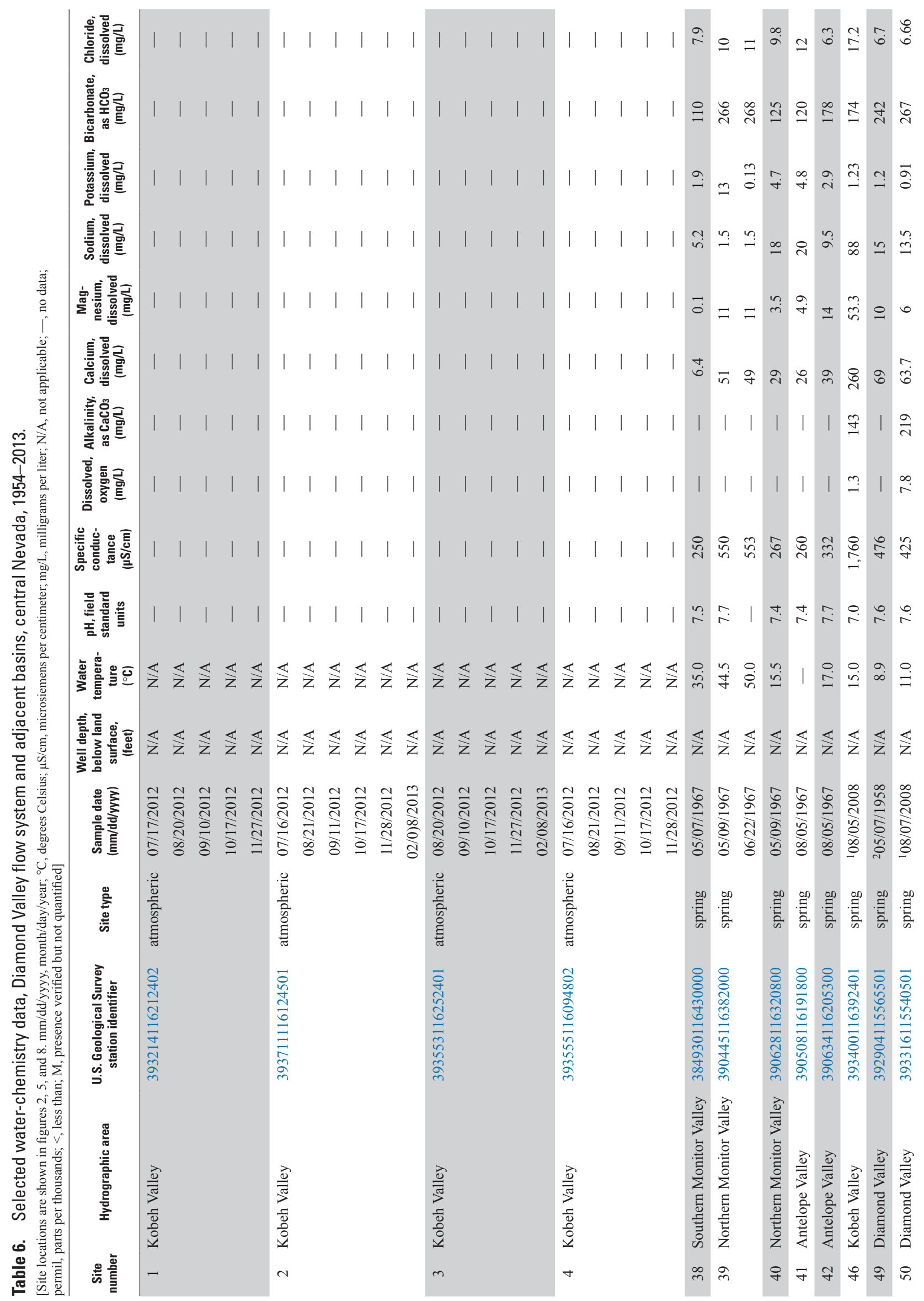




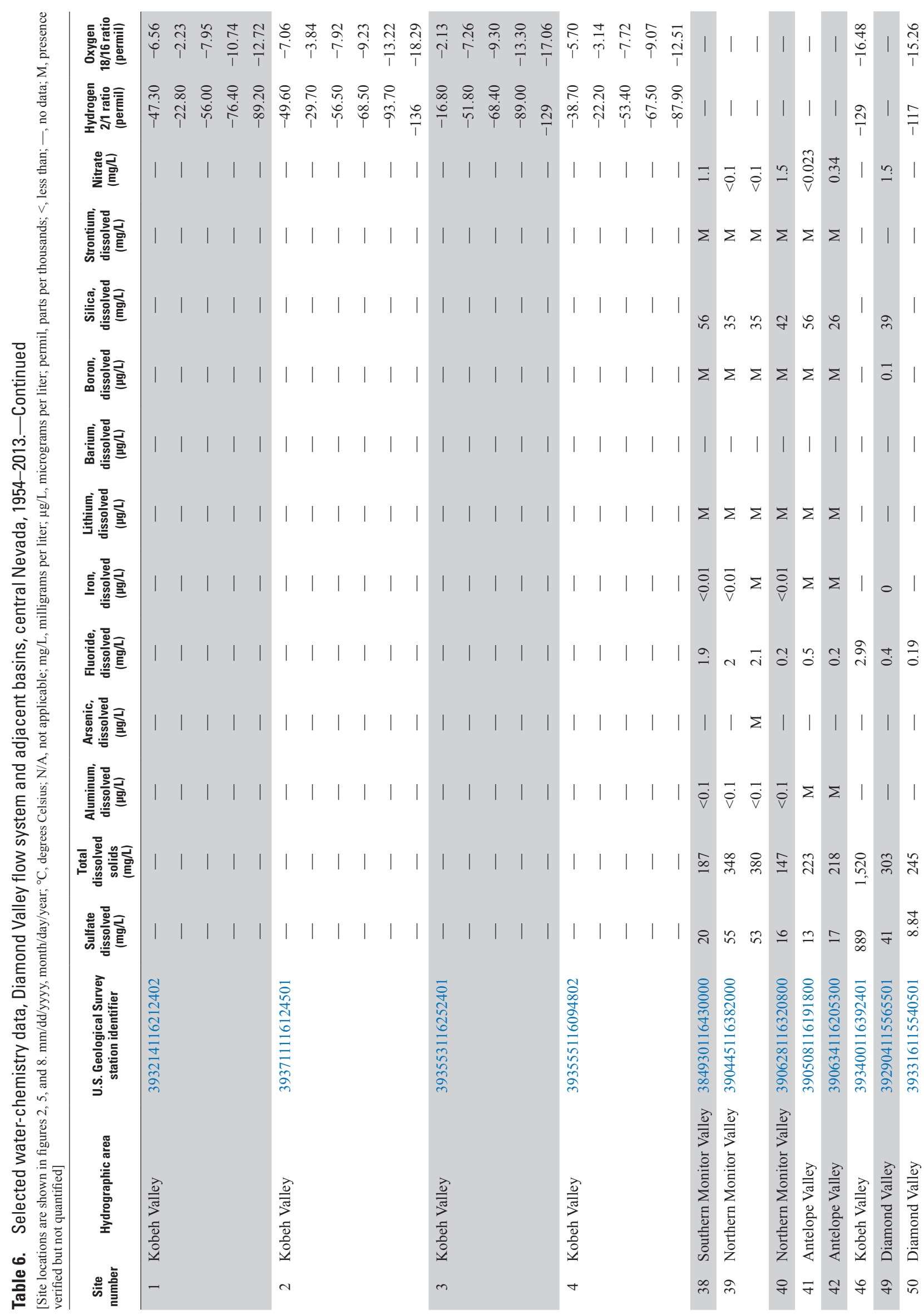




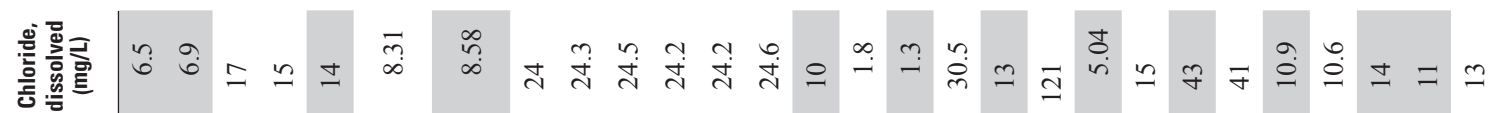

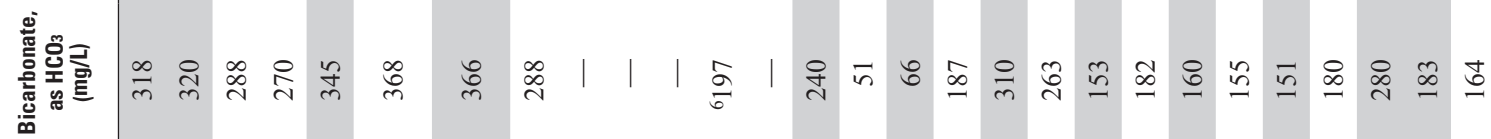

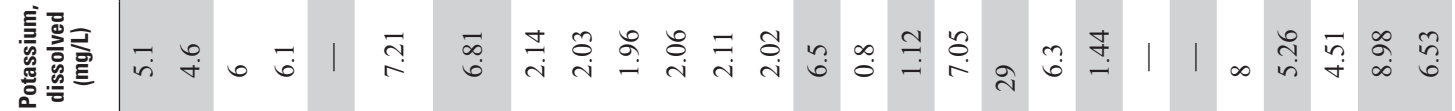

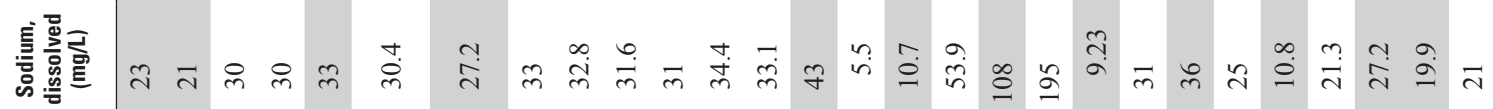

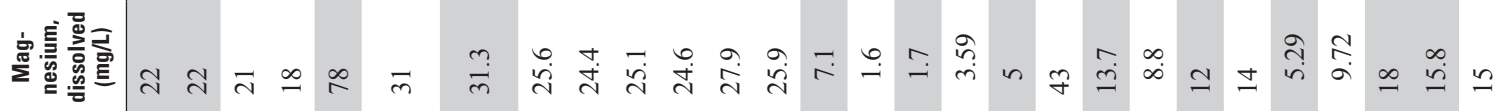

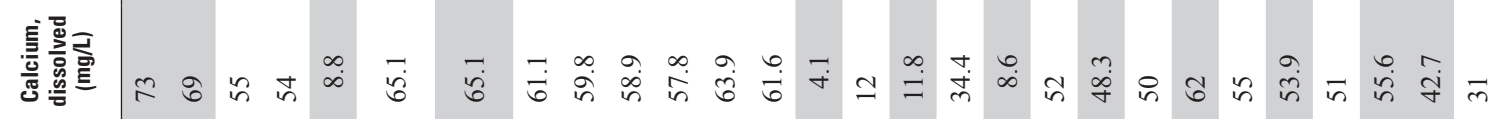

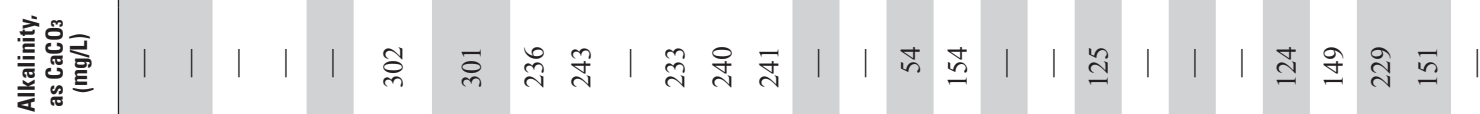

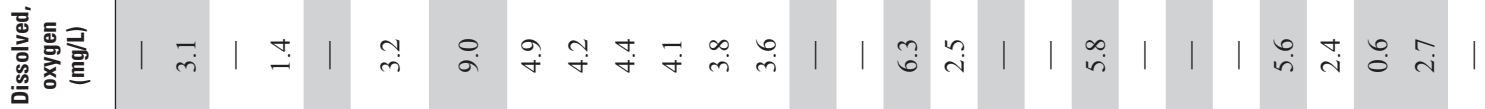

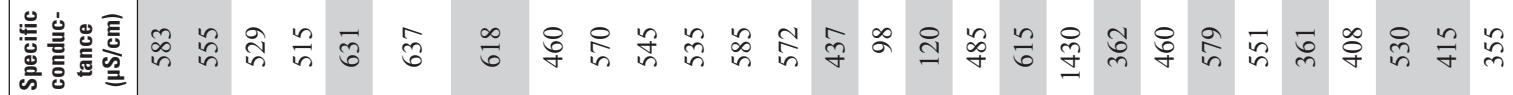

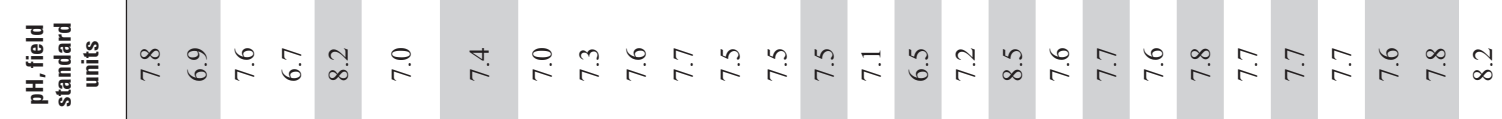

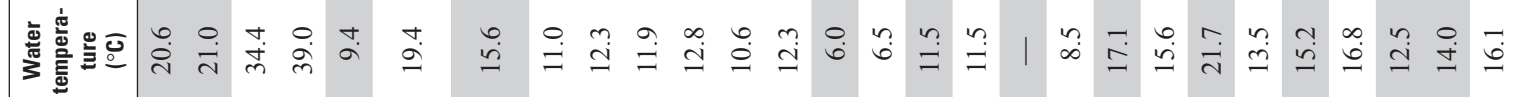

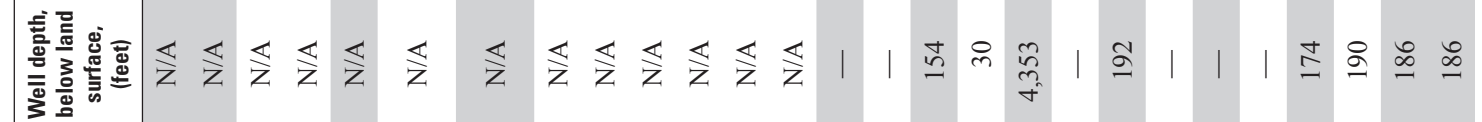

$$
\text { 은 }
$$

क人

은

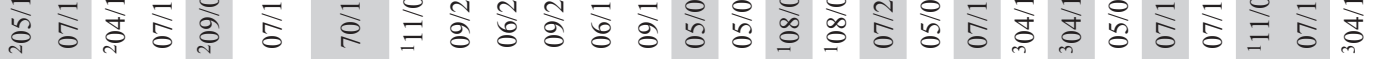




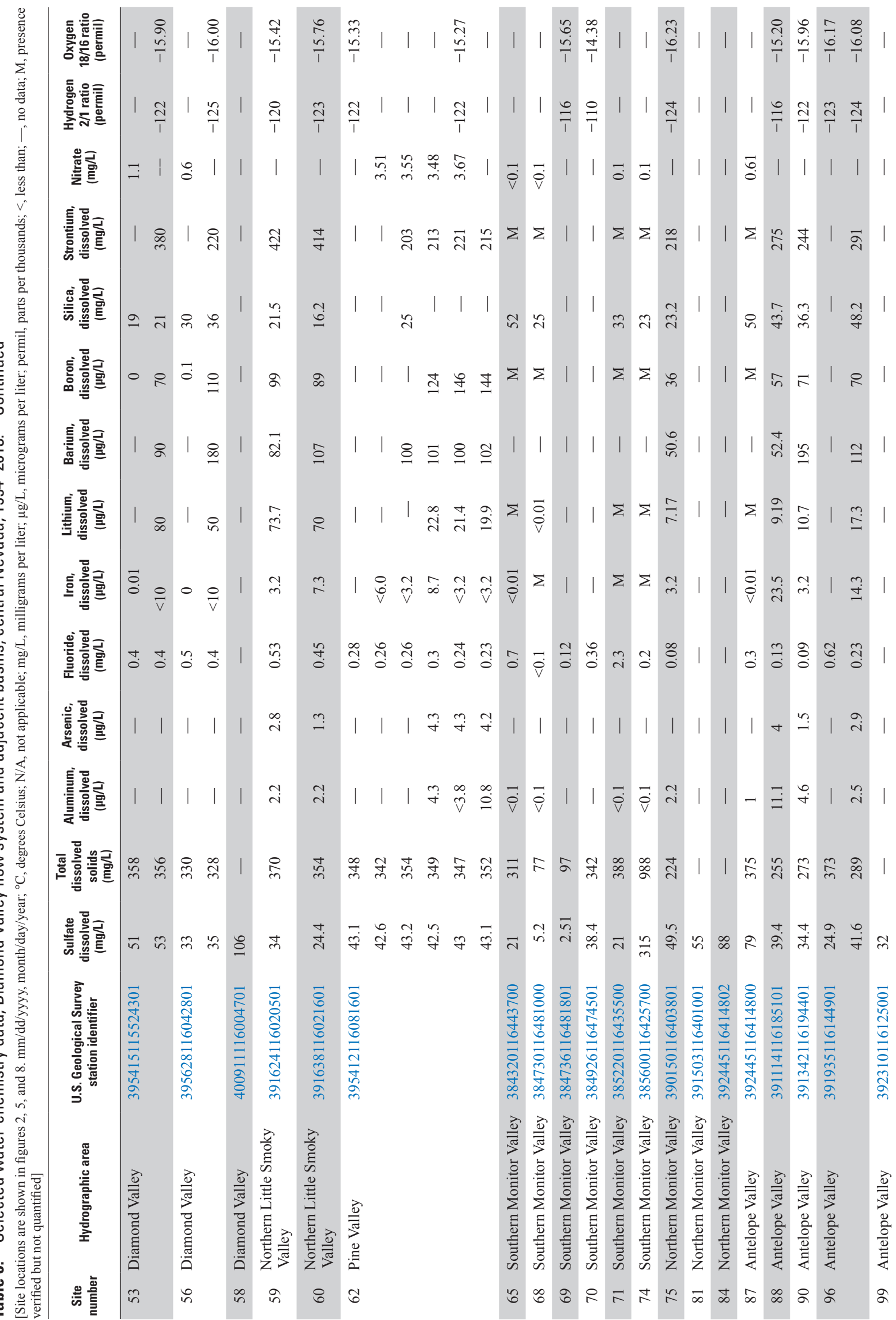




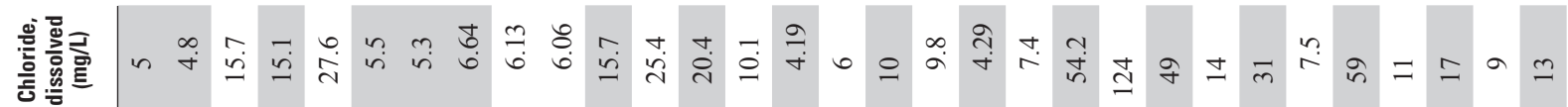

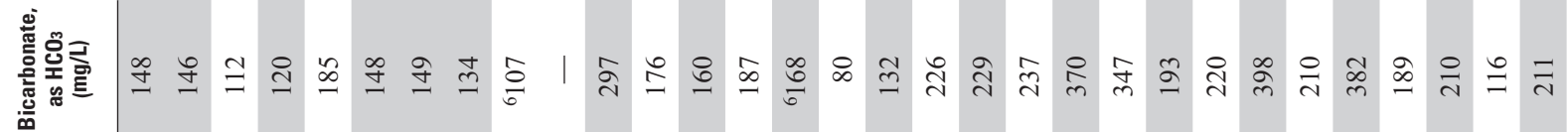

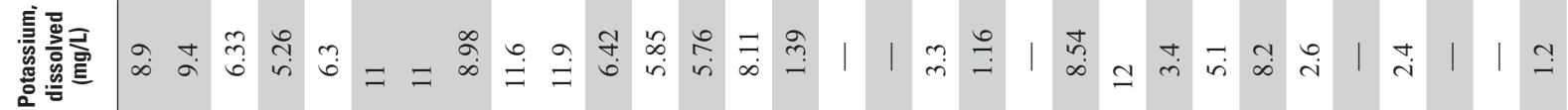

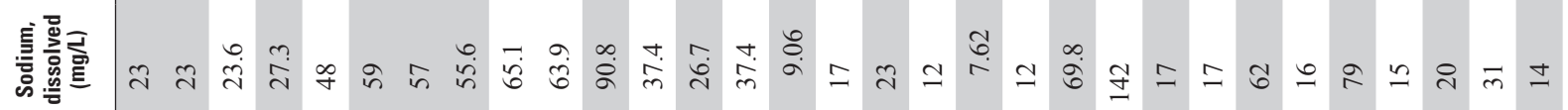

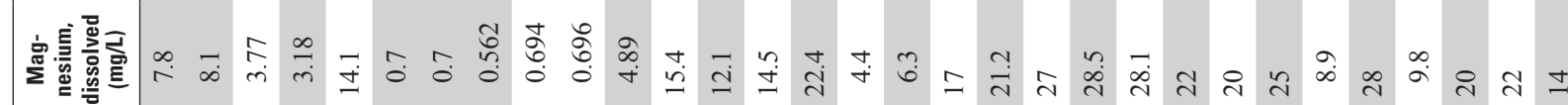

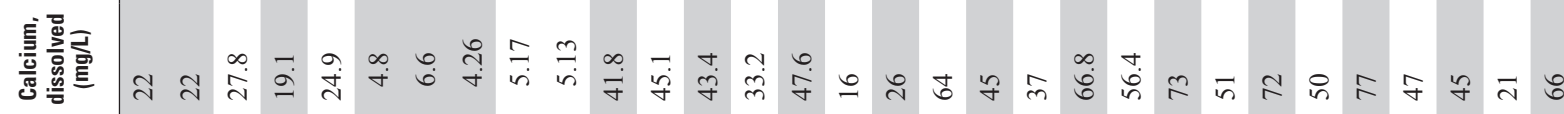

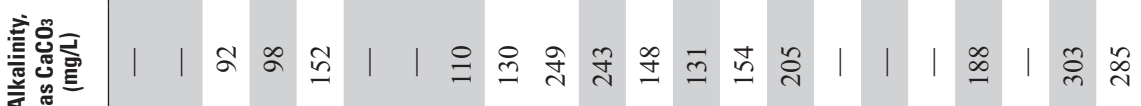

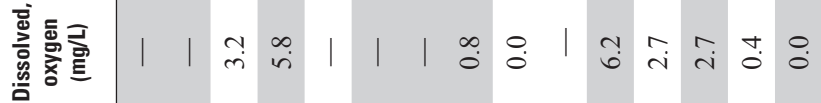

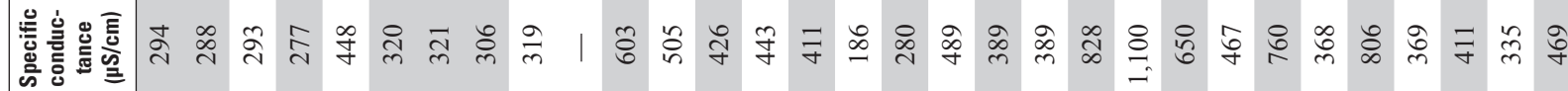

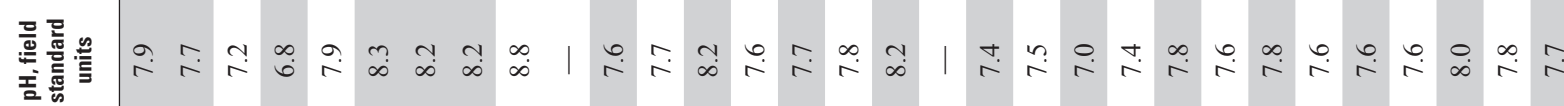

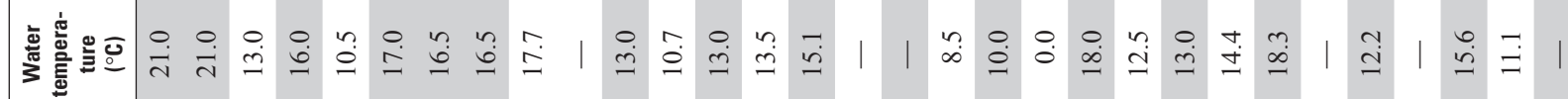

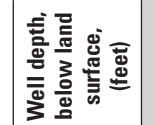

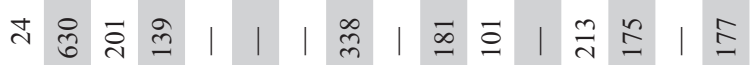
$\cong 1$ 둘

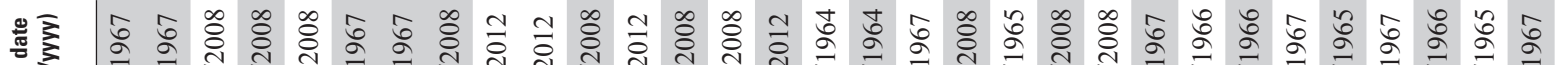

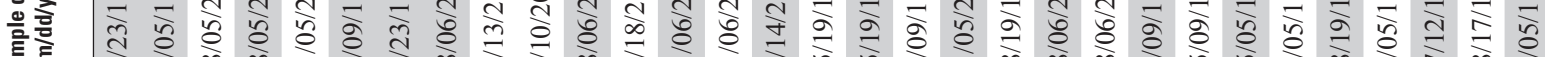

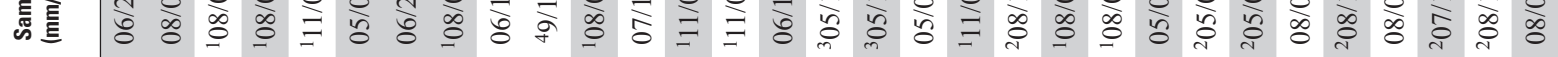

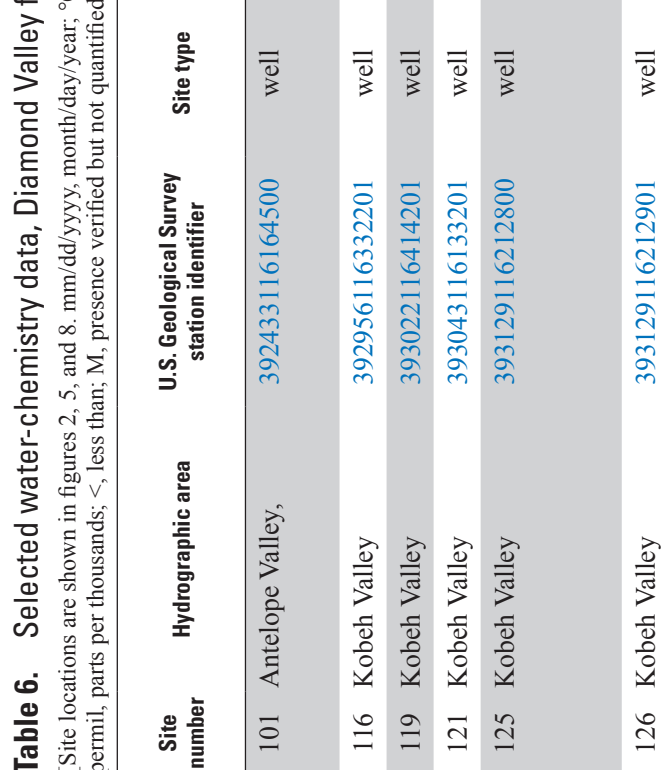

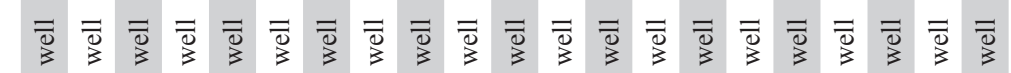

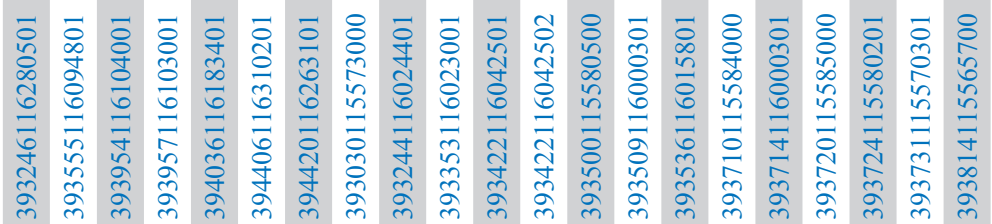




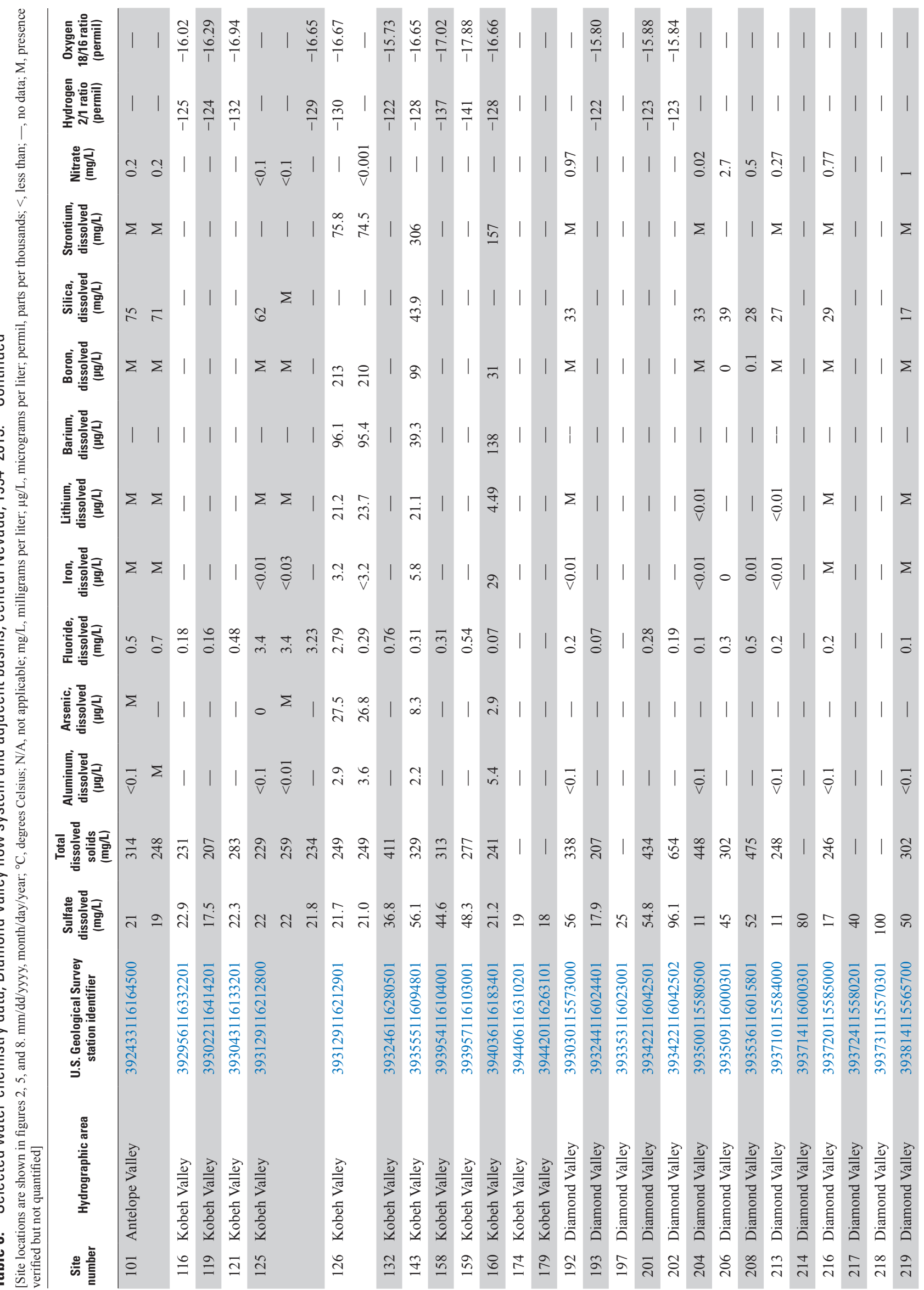




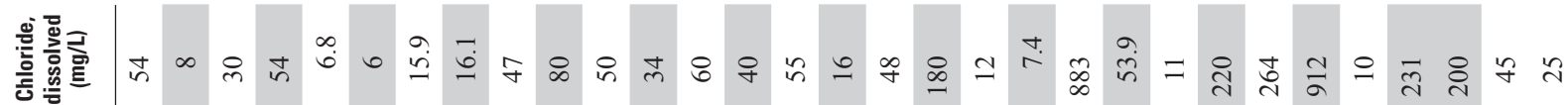

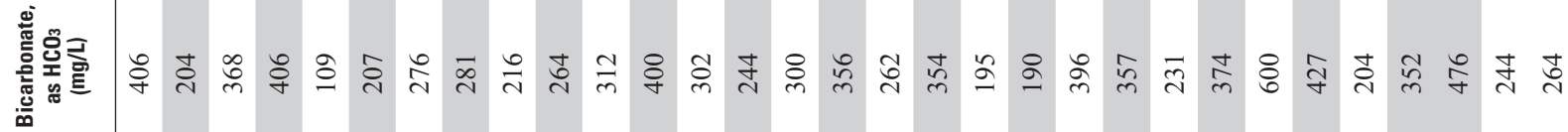

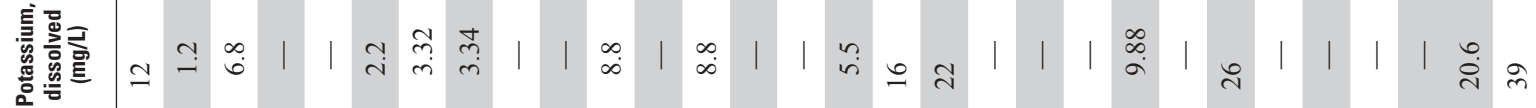

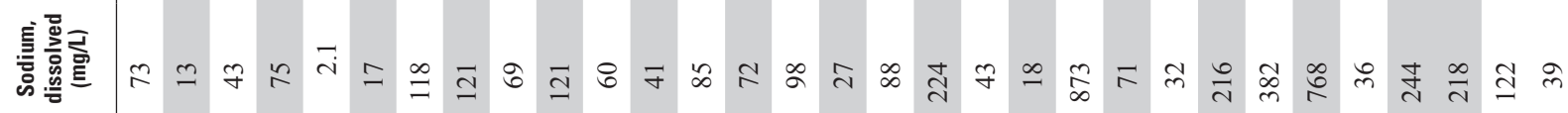

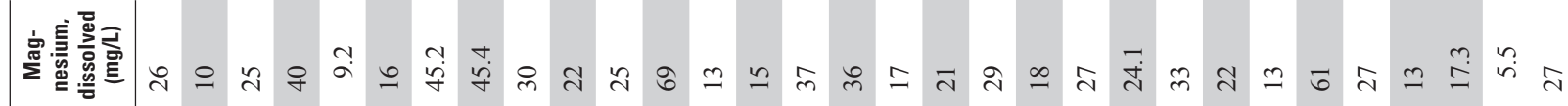

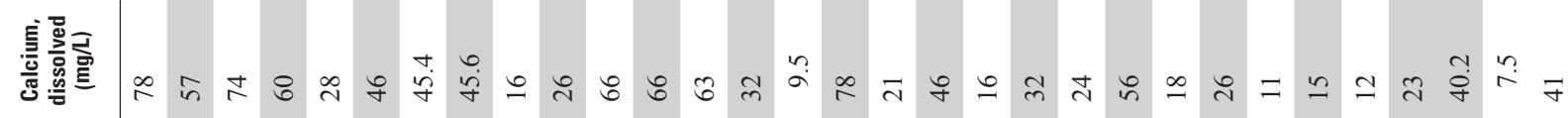

㐔记

产 สి

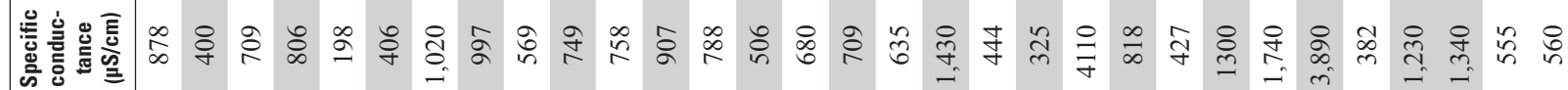

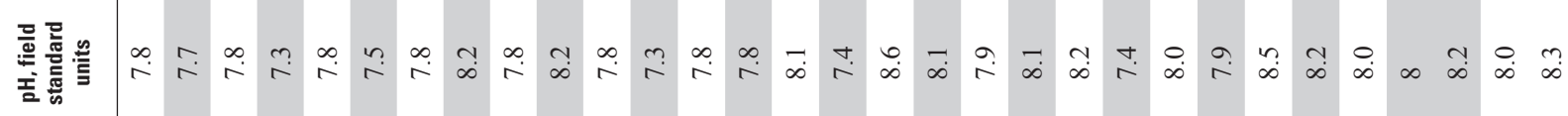

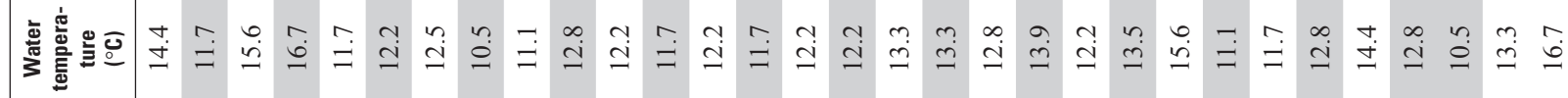

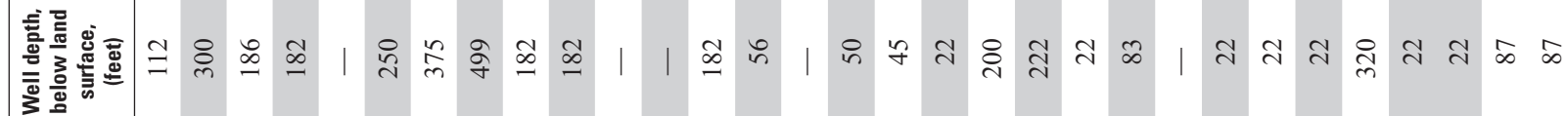

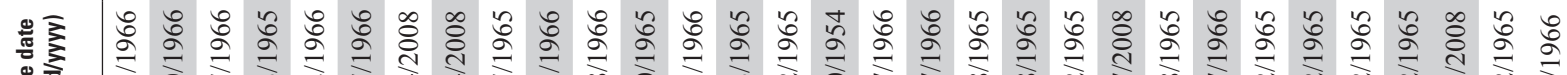

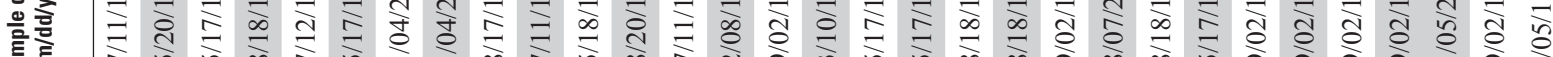

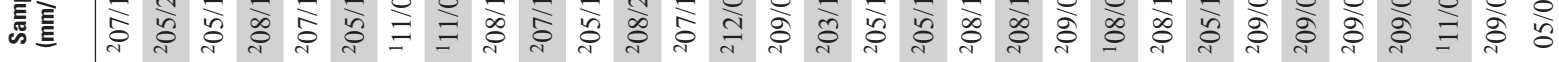



目

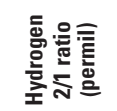

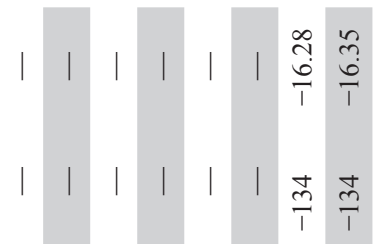

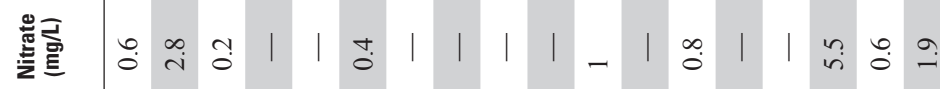

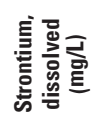

咅言

篙重重

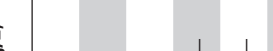

离

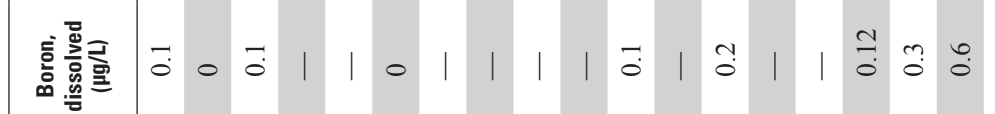

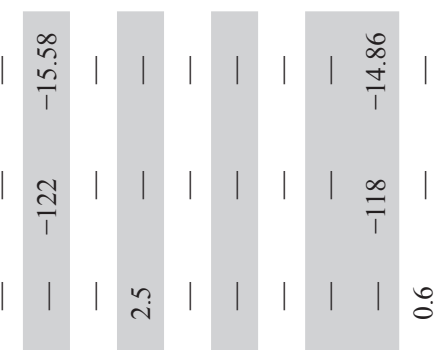

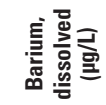

搵

要离

文

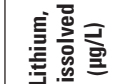

+

政

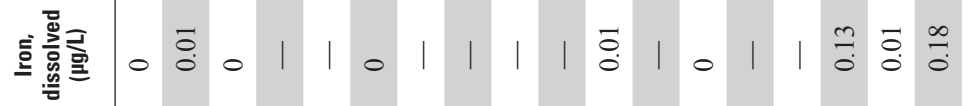

$\because 1111, \frac{5}{0}$

站

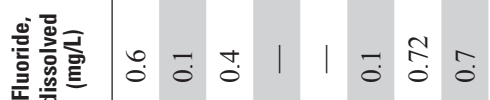

$\because 1311: 8:$

$\approx$

$5:$

离

苟

离尊

崈弪

产

के

范

产

믈 흏

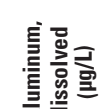

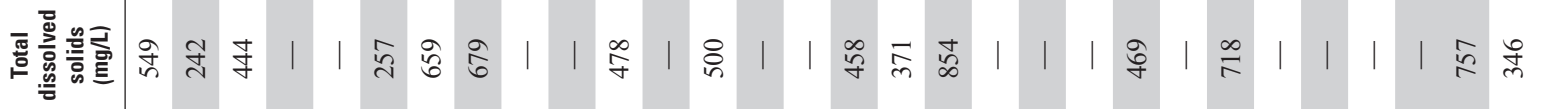

臬

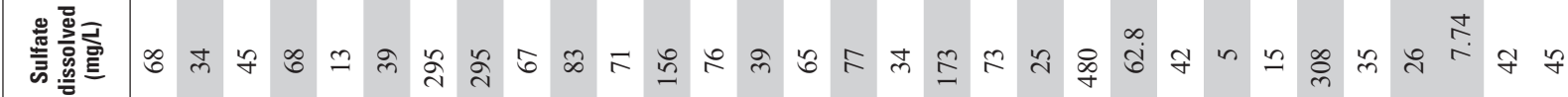

要

蕉

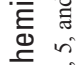

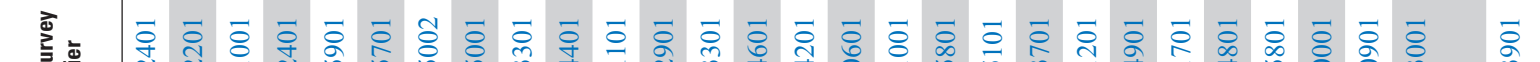

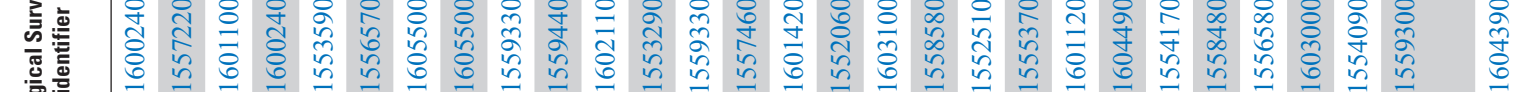

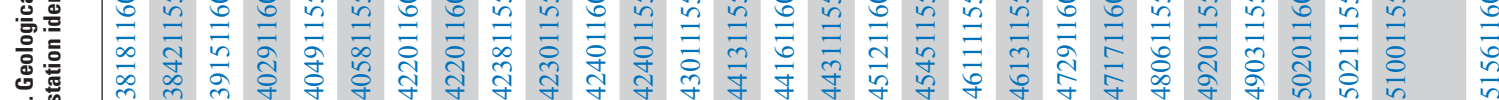

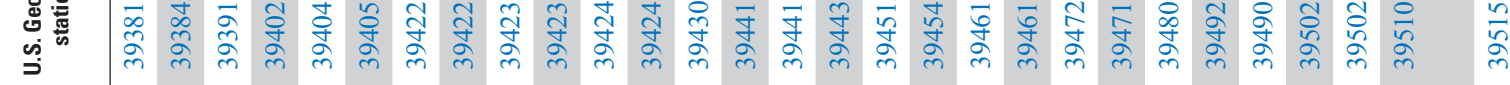

产

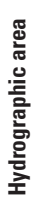

๑ 要

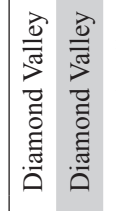

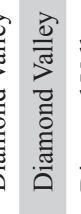

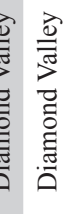
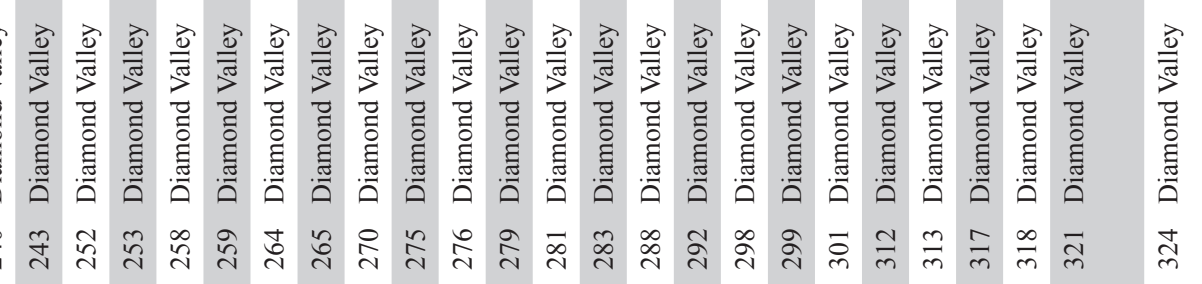

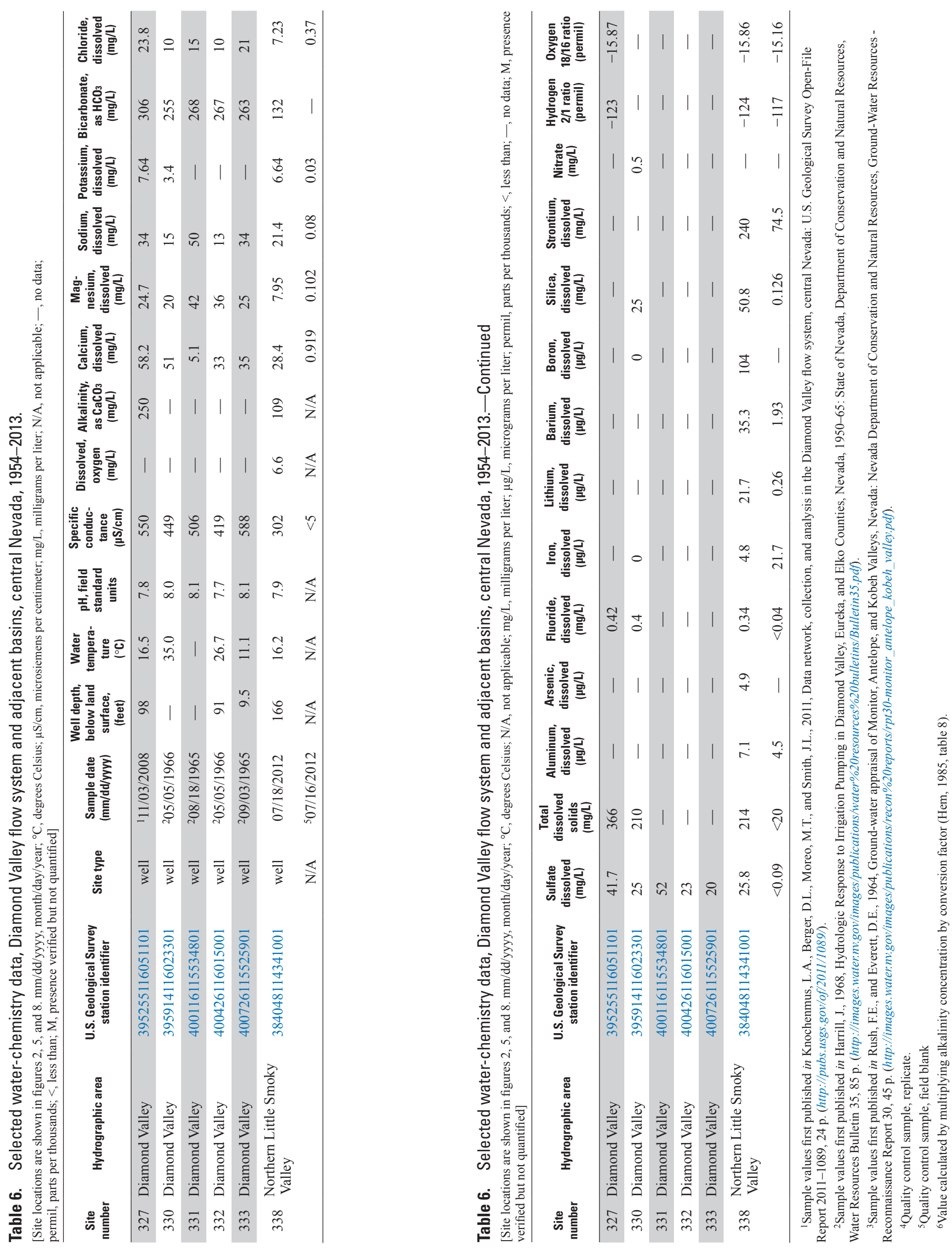
Table 7. Specific conductance, sodium, chloride, and total dissolved-solids concentrations from selected sites along northerly flowpath in southern Diamond Valley, central Nevada, 1965-67.

$[\mu \mathrm{S} / \mathrm{cm}$, microsiemens per centimeter; $\mathrm{mg} / \mathrm{L}$, milligrams per liter; —, no data]

\begin{tabular}{|c|c|c|c|c|}
\hline $\begin{array}{c}\text { Site } \\
\text { number }\end{array}$ & $\begin{array}{l}\text { Specific conductance } \\
(\mu \mathrm{S} / \mathrm{cm})\end{array}$ & $\begin{array}{l}\text { Sodium dissolved } \\
(\mathrm{mg} / \mathrm{L})\end{array}$ & $\begin{array}{l}\text { Chloride dissolved } \\
\text { (mg/L) }\end{array}$ & $\begin{array}{c}\text { Total dissolved solids } \\
(\mathrm{mg} / \mathrm{L})\end{array}$ \\
\hline \multicolumn{5}{|c|}{ Upgradient sites } \\
\hline 197 & 389 & 12 & 7.4 & - \\
\hline 204 & 650 & 17 & 49 & 448 \\
\hline 206 & 467 & 17 & 14 & 302 \\
\hline 213 & 368 & 16 & 7.5 & 248 \\
\hline 214 & 806 & 79 & 59 & - \\
\hline 216 & 369 & 15 & 11 & 246 \\
\hline 217 & 411 & 20 & 17 & - \\
\hline 218 & 335 & 31 & 9 & - \\
\hline 219 & 469 & 14 & 13 & 302 \\
\hline 220 & 878 & 73 & 54 & 549 \\
\hline 223 & 400 & 13 & 8 & 242 \\
\hline 226 & 709 & 43 & 30 & 444 \\
\hline 234 & 806 & 75 & 54 & - \\
\hline 243 & 406 & 17 & 6 & 257 \\
\hline Average & 533 & 32 & 24 & 338 \\
\hline \multicolumn{5}{|c|}{ Mid-gradient sites } \\
\hline 258 & 569 & 69 & 47 & - \\
\hline 259 & 749 & 121 & 80 & - \\
\hline 264 & 758 & 60 & 50 & 478 \\
\hline 270 & 788 & 85 & 60 & 500 \\
\hline 275 & 506 & 72 & 40 & - \\
\hline 276 & 680 & 98 & 55 & - \\
\hline 281 & 635 & 88 & 48 & 371 \\
\hline Average & 669 & 85 & 54 & 450 \\
\hline \multicolumn{5}{|c|}{ Down-gradient sites } \\
\hline 283 & 1,430 & 224 & 180 & 854 \\
\hline 292 & 325 & 18 & 7.4 & - \\
\hline 298 & 4,110 & 873 & 883 & - \\
\hline 312 & 1,300 & 216 & 220 & 718 \\
\hline 313 & 1,740 & 382 & 264 & - \\
\hline 317 & 3,890 & 768 & 912 & - \\
\hline 318 & 382 & 36 & 10 & - \\
\hline 321 & 1,340 & 218 & 200 & 757 \\
\hline Average & 1,815 & 342 & 335 & 776 \\
\hline
\end{tabular}




\section{Estimation of Groundwater-Budget Components}

Groundwater budgets describe the balance of water moving into and out of a groundwater system. Groundwater budgets include components of outflow, components of inflow, and the change in aquifer storage (equation 1). Basin-scale groundwater-inflow components include precipitation-derived mountain-block recharge (in place), infiltration of streamflow and runoff, and subsurface inflow. Groundwater-outflow components include groundwater ET, groundwater withdrawals, and subsurface outflow.

$$
\text { Recharge }+G W_{i}-E T_{g w}-G W_{o}-P=\Delta \text { Storage }
$$

where

Recharge is groundwater recharge from direct precipitation and infiltration of streamflow and runoff,

$G W_{i}$ is subsurface inflow of groundwater,

$E T_{g w}$ is groundwater discharge by evapotranspiration,

$G W_{o}$ is subsurface outflow of groundwater,

$P \quad$ is groundwater withdrawals, and

$\Delta$ Storage is the change in aquifer storage.

Groundwater discharge through springs and seeps is eventually lost as $\mathrm{ET}_{\mathrm{gw}}$, or it reenters the groundwater system as recharge; therefore, it was not considered a separate outflow component in undeveloped basins. The accuracy of a groundwater budget depends on the accuracy of the rates estimated for each of the components; small differences in some rates can produce large differences in annual-budget estimates.

Groundwater budgets in mostly undeveloped basins, such as southern and northern Monitor, Antelope, and Kobeh Valleys and Stevens Basin, were assumed to be in a general state of dynamic equilibrium, where inflow equals outflow, and net changes in storage are negligible. In contrast, substantial groundwater development in the southern part of Diamond Valley has altered the hydrologic flow system by substantially reducing groundwater storage and generating a groundwater cone of depression. Declining groundwater levels, especially in the southern part of Diamond Valley, have likely contributed to spring-flow loss in northern Diamond Valley and have induced a groundwater divide that could draw poor-quality water south toward the major groundwater development area. The groundwater budget for Diamond Valley must consider pumping and changes in $\mathrm{ET}_{\mathrm{gw}}$ and groundwater storage.

\section{Groundwater Discharge}

Groundwater discharge by ET from areas of phreatophytes and by evaporation from playas is the largest natural outflow component in the DVFS. Groundwater predominantly discharges from topographically low areas, where groundwater is at or near the land surface, that are referred to as groundwater discharge areas (GDA). Groundwater withdrawals for irrigation, which were almost entirely in the southern part of Diamond Valley, represented the largest groundwater-outflow component of the post-development budget.

\section{Evapotranspiration}

Evapotranspiration was measured and $\mathrm{ET}_{\mathrm{gw}}$ was estimated at four sites in Kobeh Valley using eddy-covariance and other micrometeorological data (Swinbank, 1951; Campbell and Norman, 1998; Foken and others, 2012). Groundwater discharge was computed as annual ET minus precipitation plus the change in soil-water storage. Most, if not all, precipitation falling directly onto the land surface in a GDA is eventually consumed by ET and, therefore, was assumed not to contribute to the regional groundwater-flow system. Surface-water contributions to ET in a GDA were assumed to be negligible. Site-based data were scaled to the basin and flow system using remote sensing and 30-year (1981-2010) PRISM precipitation model data.

\section{Surface Energy Budget}

Incoming and outgoing energy fluxes that constrain the energy available for ET describe the land-surface energy budget. The energy budget generally is partitioned into four principle components: net radiation $\left(\mathrm{R}_{\mathrm{n}}\right)$, latent- $(\lambda \mathrm{E})$ and sensible-heat $(\mathrm{H})$ fluxes, and the soil-heat flux at land surface (G). Based on the principle of energy conservation, available energy (difference between net radiation, $R_{n}$, and soil heat flux, $\mathrm{G}$ ) is equal to additive turbulent fluxes of $\lambda \mathrm{E}$ and $\mathrm{H}$ (equation 2):

$$
R_{n}-G=\lambda E+H
$$

where all components are in units of calories per second per square foot. Net radiation is the energy that drives ET and represents the difference between incoming and outgoing shortwave and longwave radiation. The latent-heat flux $(\lambda \mathrm{E})$ is defined as the energy consumed during ET. The latent heat of vaporization $(\lambda)$ is the amount of energy needed to evaporate a unit mass of water, and the E component of the latent-heat flux term is the mass flux of water vapor, or ET in ounces per second per square foot. Evapotranspiration can be converted to a rate of surface discharge by dividing by the density of water. Sensible-heat flux $(\mathrm{H})$ is the heat energy convectively removed from the surface owing to temperature differences between the surface and atmosphere. The soil-heat flux at land surface $(G)$ is positive when heat moves from the surface to the subsurface.

Latent- and sensible-heat fluxes were measured and computed using the eddy-covariance method, which measures the one-dimensional net transport of heat, mass, and momentum by eddies between surface and atmospheric boundaries (Foken and others, 2012). Eddies are turbulent air movements caused by wind, surface roughness, and convective heat flow at these boundaries (Swinbank, 1951; Campbell and Norman, 
1998). The eddy-covariance method relies on high-frequency (10 Hertz, or Hz, in this study) measurements of fluctuations in vertical wind speed, air temperature, and water-vapor density to measure latent- and sensible-heat fluxes.

\section{Site Selection and Characteristics}

Groundwater discharge was estimated at four sites. These sites were selected and instrumented to measure ET and energy-budget components, groundwater levels, precipitation, soil-water content, and other variables affecting $\mathrm{ET}_{\mathrm{gw}}$ (sites 1-4; fig. 2; table 1). All sites were in undisturbed vegetated areas on the valley floor in Kobeh Valley; three sites were in phreatophytic shrubland, and one site was in grassland (figs. $11 \boldsymbol{A}, \boldsymbol{B})$. The line-transect method (Smith, 1974) was used during spring 2012 to document plant-species dominance and measure canopy height and the percentage of canopy cover at the three shrubland sites. Surveys summarized measurements from four 328-ft transects extending north, west, south, and east from a point near each eddy-covariance instrument tripod (see "Instrumentation" section). Canopy height was computed as the average plant height measured across all transects (table 8). The length of the vertical projection of green (active) plant canopies along line transects was used to compute the percentage of canopy cover. Bare-soil cover included gaps between plants and under plant canopies. Percentage of canopy cover was computed as the ratio of the sum of individual measured canopy lengths across all transects to the total transect length $(1,312 \mathrm{ft})$ and was assumed to represent the predominant ET measurement source area (table 8). Vegetation and soil characteristics were subsequently monitored at all ET sites during site visits, and photographs were taken periodically to document the greenness and vigor of vegetation and the presence or absence of soil moisture.

Site 1 was established at an altitude of about $6,099 \mathrm{ft}$ on June 7, 2011, in an area of sparse shrubland (fig. 2; table $1)$. Vegetation density was evaluated in terms of vegetation cover and height. The site was characterized by about 15 -percent vegetation cover (about 12-percent phreatophyte cover) and 85 percent bare soil (figs. $11 \boldsymbol{A}, \boldsymbol{B}$; table 8 ). The vegetation was composed of greasewood (Sarcobatus vermiculatus, 16-percent relative canopy cover) and rabbitbrush (Chrysothamnus spp., 62-percent relative canopy cover), with lesser amounts of non-phreatophytes (xerophytes, that is, plants adapted to an arid environment), including budsage (Artemisia spinescens) and sagebrush (Artemisia tridentata). Average canopy heights of greasewood and rabbitbrush were 0.9 and $0.4 \mathrm{ft}$, respectively. Volumetric soil-water content ranged from about 0.01 to $0.18 \mathrm{in}^{3} / \mathrm{in}^{3}$ (fig. 12). Depth to groundwater measured in a collocated well (site 130; fig. 5; table 5) averaged $8.8 \mathrm{ft}$ below land surface and ranged from about 8.7 to $9.1 \mathrm{ft}$ (June 2011-September 2012; fig. 13).

Site 2 was established at an altitude of about $6,052 \mathrm{ft}$ on July 8, 2010 (fig. 2; table 1). This site was characterized by about 16-percent vegetation cover (more than 99-percent phreatophytes) and 84 percent bare soil and was considered to represent moderate-to-dense shrubland (figs. 11A, B; table 8). Greasewood and rabbitbrush (39- and 35-percent relative canopy cover, respectively) were the dominant vegetation, with a lesser amount of saltgrass (Distichlis spicata; 26-percent relative canopy cover). Xerophytic vegetation was predominantly sagebrush. The average canopy heights of greasewood and rabbitbrush were 0.9 and $1.2 \mathrm{ft}$, respectively, and the average rabbitbrush height was three times that measured at site 1 . Volumetric soil-water content ranged from about 0.10 to 0.25 $\mathrm{in}^{3} / \mathrm{in}^{3}$ (fig. 12). Depth to groundwater measured in a collocated well (site 150; fig. 5; table 5) averaged $2.3 \mathrm{ft}$ below land surface and ranged from 1.7 to $2.6 \mathrm{ft}$ (July 2010-September 2012; fig. 13).

Site 3 was established at an altitude of about $6,131 \mathrm{ft}$ on July 7, 2010 (fig. 2; table 1). This site was characterized by about 14-percent vegetation cover (all phreatophytes) and 86-percent bare soil and was considered to represent moderate-to-dense shrubland. Shrubs were composed of greasewood (22-percent relative canopy cover) and rabbitbrush (25-percent relative canopy cover), whereas grasses were composed of undifferentiated bunch grass (25-percent relative canopy cover) and saltgrass (28 percent relative canopy cover; figs. $11 \boldsymbol{A}, \boldsymbol{B}$; table 8 ). Average canopy heights of greasewood and rabbitbrush were 1.3 and $2.1 \mathrm{ft}$, respectively, and were more than 1.5 times as tall as the same species measured at site 2 . The average bunch grass height was about $0.5 \mathrm{ft}$.

Table 8. Vegetation type, canopy cover, and height measured at four evapotranspiration sites, May 2012, Kobeh Valley, Nevada.

[Bunch grass height represents the average height of the bulk of mass. - , no data]

\begin{tabular}{|c|c|c|c|c|c|c|c|c|c|c|c|c|}
\hline \multirow{3}{*}{$\begin{array}{c}\text { Site } \\
\text { number }\end{array}$} & \multirow{2}{*}{\multicolumn{2}{|c|}{$\begin{array}{l}\text { Canopy cover } \\
\text { (percent) }^{1}\end{array}$}} & \multicolumn{4}{|c|}{ Phreatophyte shrubs } & \multicolumn{6}{|c|}{ Phreatophyte grasses } \\
\hline & & & \multicolumn{2}{|c|}{ Greasewood } & \multicolumn{2}{|c|}{ Rabbitbrush } & \multicolumn{2}{|c|}{ Bunch grass } & \multicolumn{2}{|c|}{ Saltgrass } & \multicolumn{2}{|c|}{ Meadow grass } \\
\hline & All plants & Phreatophytes & $\begin{array}{c}\text { Canopy } \\
\text { cover } \\
\text { (percent) }\end{array}$ & $\begin{array}{c}\text { Average } \\
\text { height } \\
\text { (feet) }\end{array}$ & $\begin{array}{c}\text { Canopy } \\
\text { cover } \\
\text { (percent) }\end{array}$ & $\begin{array}{c}\text { Average } \\
\text { height } \\
\text { (feet) }\end{array}$ & $\begin{array}{c}\text { Canopy } \\
\text { cover } \\
\text { (percent) }\end{array}$ & $\begin{array}{c}\text { Average } \\
\text { height } \\
\text { (feet) }\end{array}$ & $\begin{array}{c}\text { Canopy } \\
\text { cover } \\
\text { (percent) }\end{array}$ & $\begin{array}{c}\text { Average } \\
\text { height } \\
\text { (feet) }\end{array}$ & $\begin{array}{c}\text { Canopy } \\
\text { cover } \\
\text { (percent) }\end{array}$ & $\begin{array}{c}\text { Average } \\
\text { height } \\
\text { (feet) }\end{array}$ \\
\hline 1 & 14.9 & 11.6 & 2.4 & 0.9 & 9.2 & 0.4 & 0.0 & - & 0.0 & - & 0.0 & - \\
\hline 2 & 15.6 & 15.5 & 6.1 & 0.9 & 5.4 & 1.2 & 0.0 & - & 4.0 & 0.3 & 0.0 & - \\
\hline 3 & 14.1 & 14.1 & 3.1 & 1.3 & 3.5 & 2.1 & 3.5 & 0.5 & 4.0 & 0.3 & 0.0 & - \\
\hline 4 & 100.0 & 100.0 & 0.0 & - & 0.0 & - & 0.0 & - & 0.0 & - & 100.0 & ${ }^{2} 0.5$ \\
\hline
\end{tabular}

${ }^{1}$ Total canopy cover for all four transects divided by the total transect length (1,312 feet); canopy cover was estimated from additive measurements of the vertical projection of green (active) plant canopies overlying line transects.

${ }^{2}$ Value represents the maximum height. Meadow grass height varied seasonally and with grazing practices. 
Site 1, sparse shrubland, August 31, 2011

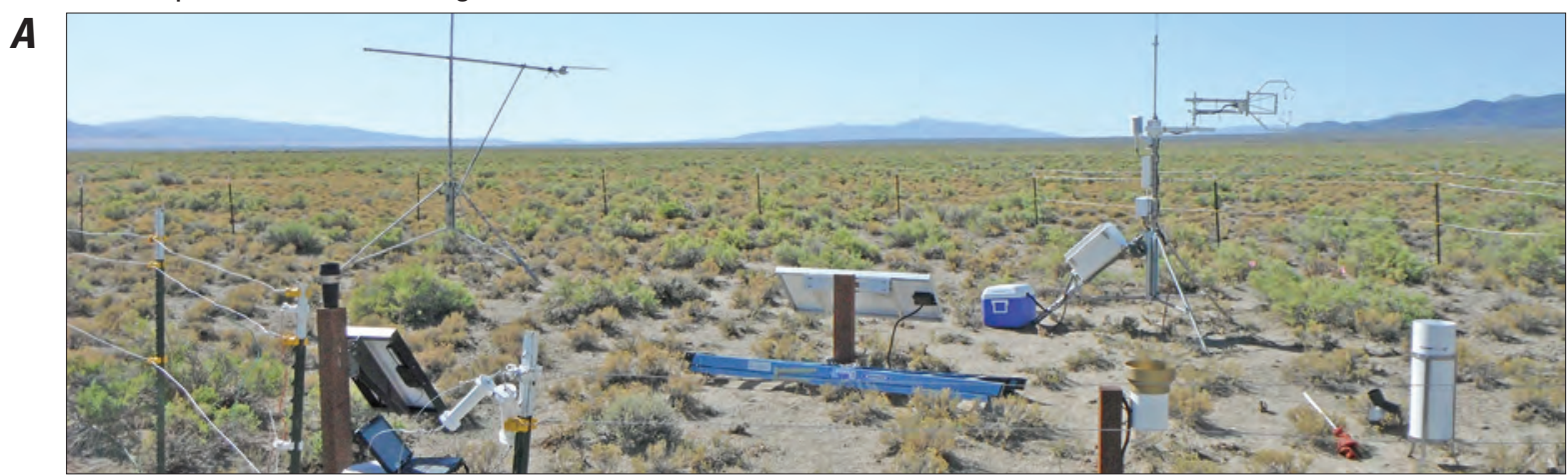

Site 2, moderate-to-dense shrubland, July 21, 2011

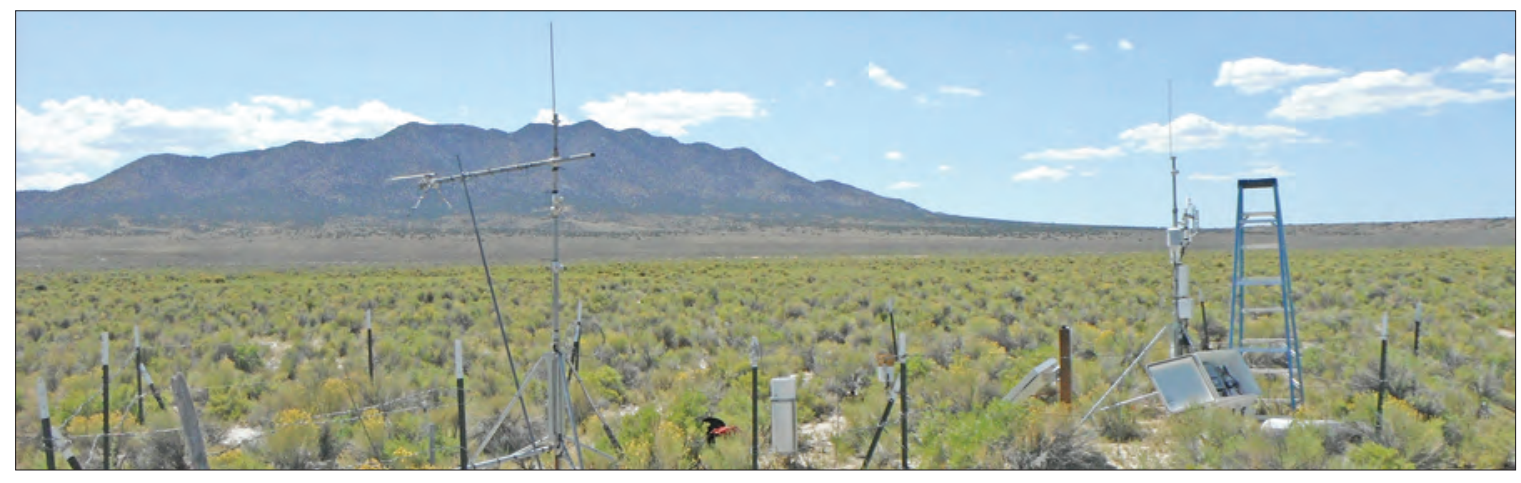

Site 3, moderate-to-dense shrubland, August 31, 2011

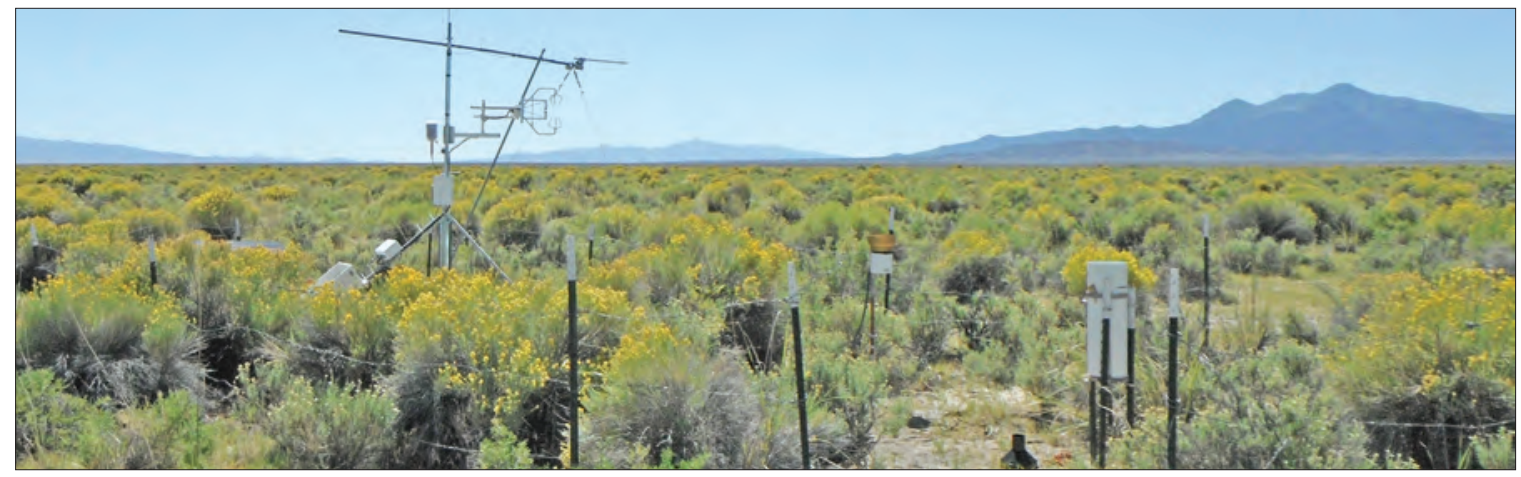

Site 4, grassland, July 20, 2011

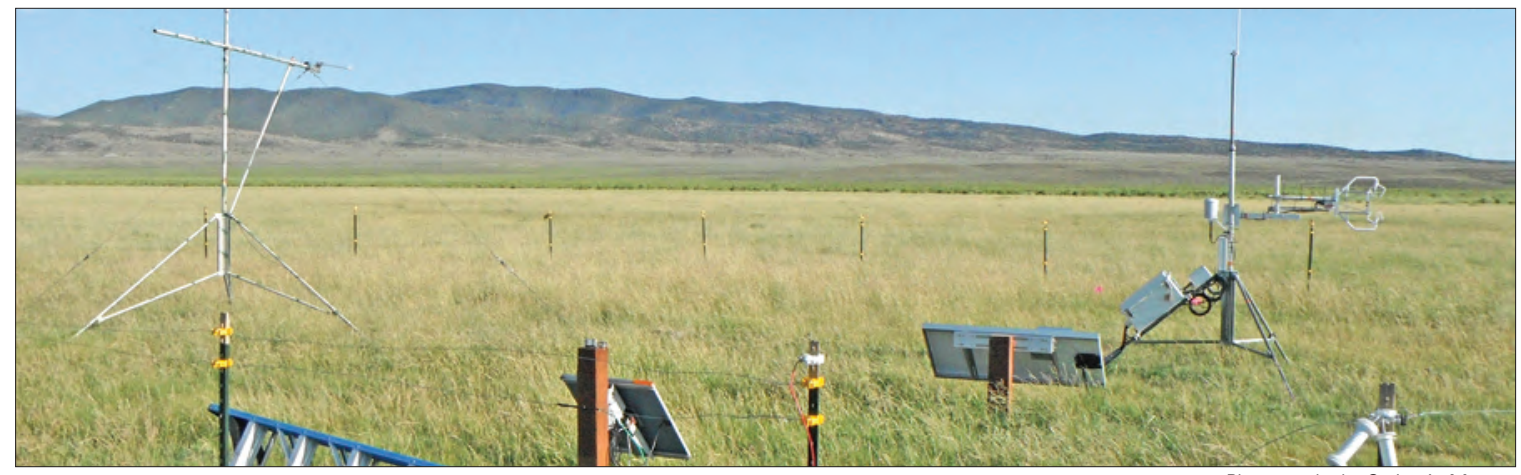

Photographs by C. Justin Mayers

Figure 11. Evapotranspiration sites, Kobeh Valley, central Nevada photographed $\boldsymbol{A}$, laterally to show instrumentation and vegetation at sites $1-4$, and, $\boldsymbol{B}$, aerially from a location approximately 328 feet west of sites $1-3$ to show vegetation distribution in an approximately 28-foot square footprint. 
B

Site 1, sparse shrubland, July 19, 2012

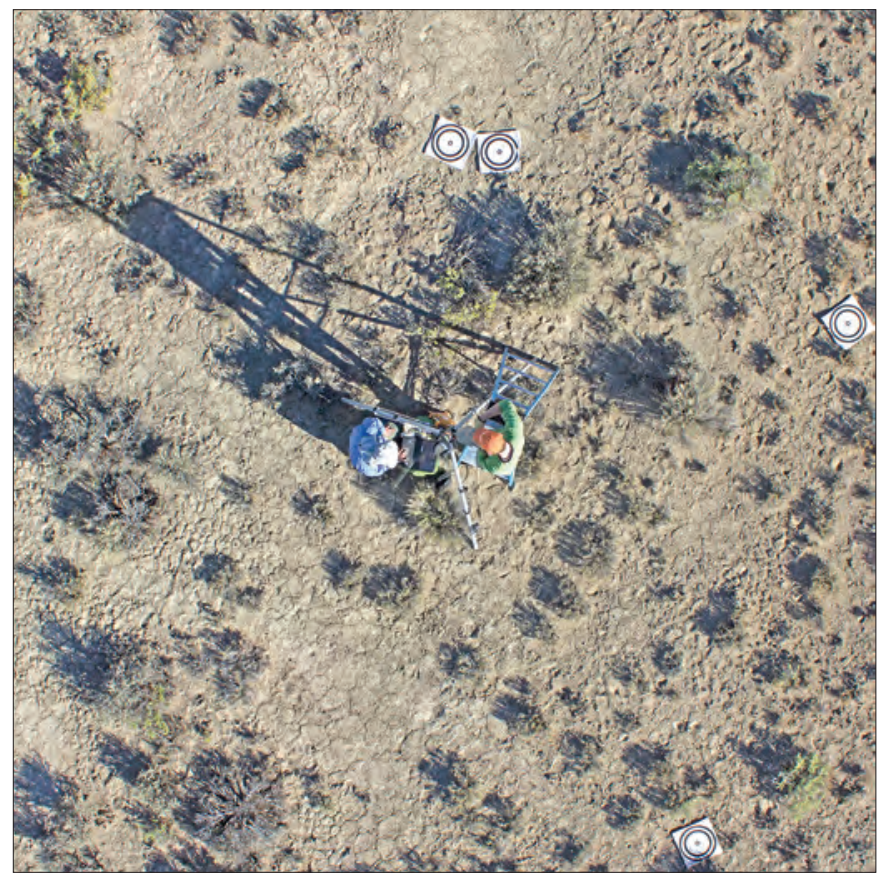

Site 3, moderate-to-dense shrubland, September 10, 2012

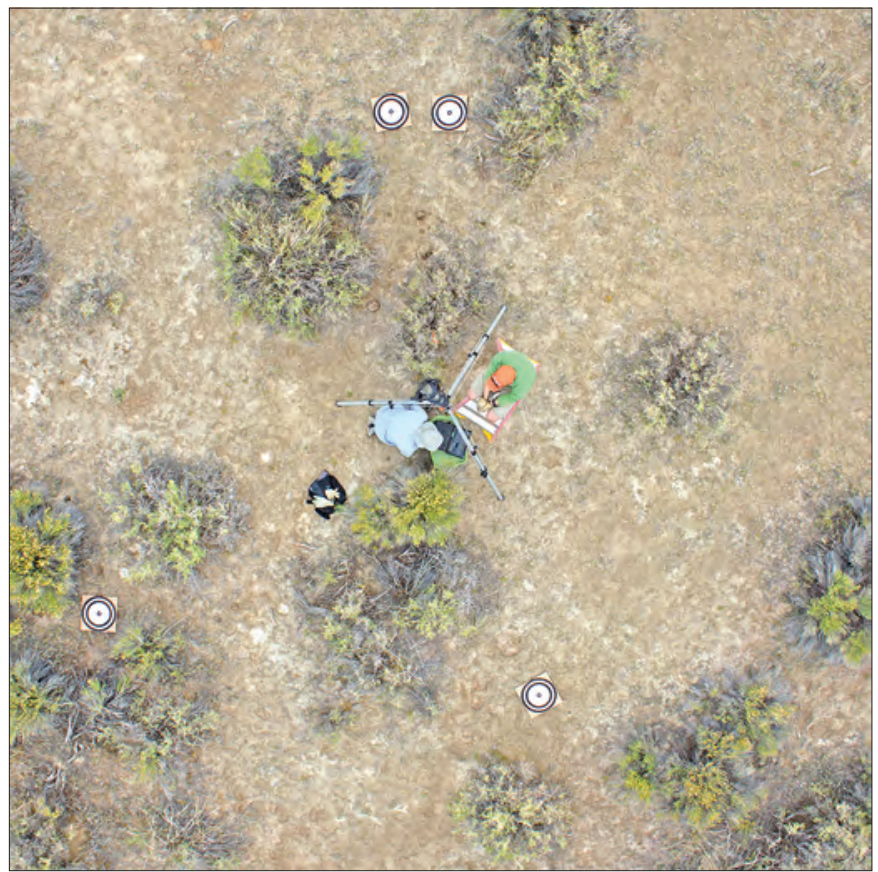

Aerial photographs by C. Justin Mayers and David W. Smith using a camera mounted on a 40 -foot tripod.

Volumetric soil-water content ranged from about 0.05 to 0.36 $\mathrm{in}^{3} / \mathrm{in}^{3}$ (fig. 12). Depth to groundwater measured in a collocated well (site 142; fig. 5; table 5) averaged $3.5 \mathrm{ft}$ below land surface and ranged from about 2.5 to $4.1 \mathrm{ft}$ (July 2010-September 2013; fig. 13).

Site 4 (fig. 2; table 1) was established at an altitude of about $6,013 \mathrm{ft}$ on June 8,2011 . This site was composed of phreatophytic meadow grasses that covered 100 percent of the measurement area (figs. $11 \boldsymbol{A}, \boldsymbol{B}$; table 8 ). The area was heavily
Site 2, moderate-to-dense shrubland, July 18, 2012

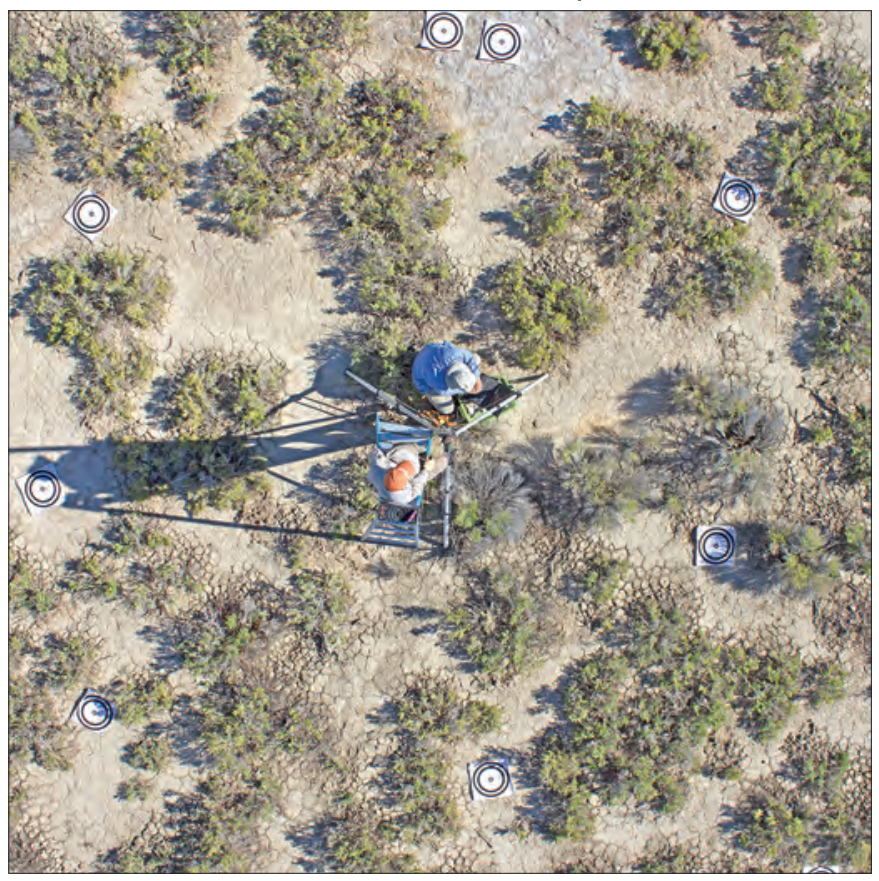

Figure 11. Evapotranspiration sites, Kobeh Valley, central Nevada photographed $\boldsymbol{A}$, laterally to show instrumentation and vegetation at sites $1-4$, and, $\boldsymbol{B}$, aerially from a location approximately 328 feet west of sites $1-3$ to show vegetation distribution in an approximately 28 -foot square footprint.Continued grazed by cattle; therefore, grass height typically was within $0.5 \mathrm{ft}$ of the land surface. The site was fenced in to protect sensors from grazing cattle; therefore, grass in the fenced area was periodically mowed to mimic grazed conditions beyond the fenced area. Volumetric soil-water content ranged from about 0.11 to $0.37 \mathrm{in}^{3} / \mathrm{in}^{3}$ (fig. 12). Depth to groundwater measured in a collocated well (site 143; fig. 5; table 5) averaged $4.1 \mathrm{ft}$ below land surface and ranged from about 3.2 to $5.1 \mathrm{ft}$ (June 2011-September 2012; fig. 13). 


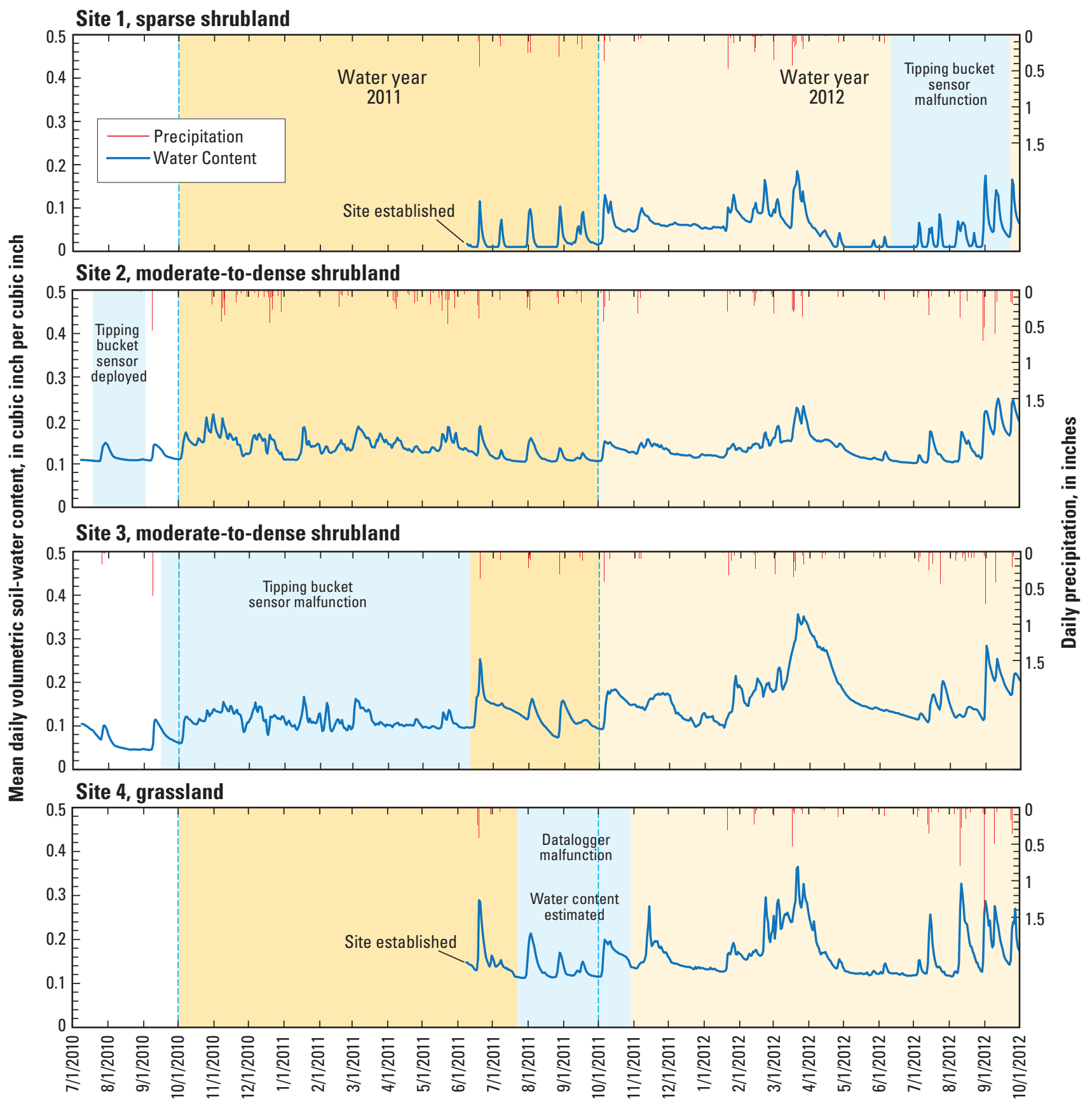

Figure 12. Continuously measured precipitation and near-surface (0.8-2.4-inches below land surface) volumetric soil-water content at evapotranspiration sites, October 2010 through September 2012, central Nevada.

\section{Instrumentation}

Each ET site was equipped with identical data recording and sensor arrays, with eddy-covariance instruments and net radiometers deployed on 10 - $\mathrm{ft}$ steel tripods. Sites also were equipped with aboveground volumetric and tipping-bucket precipitation gauges and belowground energy-flux sensors. Observation wells were equipped with pressure transducers to provide continuous groundwater-level data. Most sensors were powered with a combination of 10- and 64-watt solar panels and multiple deep-cycle marine batteries.
Turbulent fluxes were measured at high frequency $(10 \mathrm{~Hz})$ intervals using multiple sensors. Water-vapor measurements were obtained using a krypton hygrometer (KH2O, Campbell Scientific, Inc.), and wind-speed vectors and sonic temperature measurements were obtained with a three-dimensional (3-D) sonic anemometer (CSAT3, Campbell Scientific, Inc.). Absolute water-vapor density was measured with a temperature/ humidity probe (HMP45C, Campbell Scientific, Inc.). These high frequency data were recorded using an electronic datalogger (CR5000, Campbell Scientific, Inc.). The datalogger 

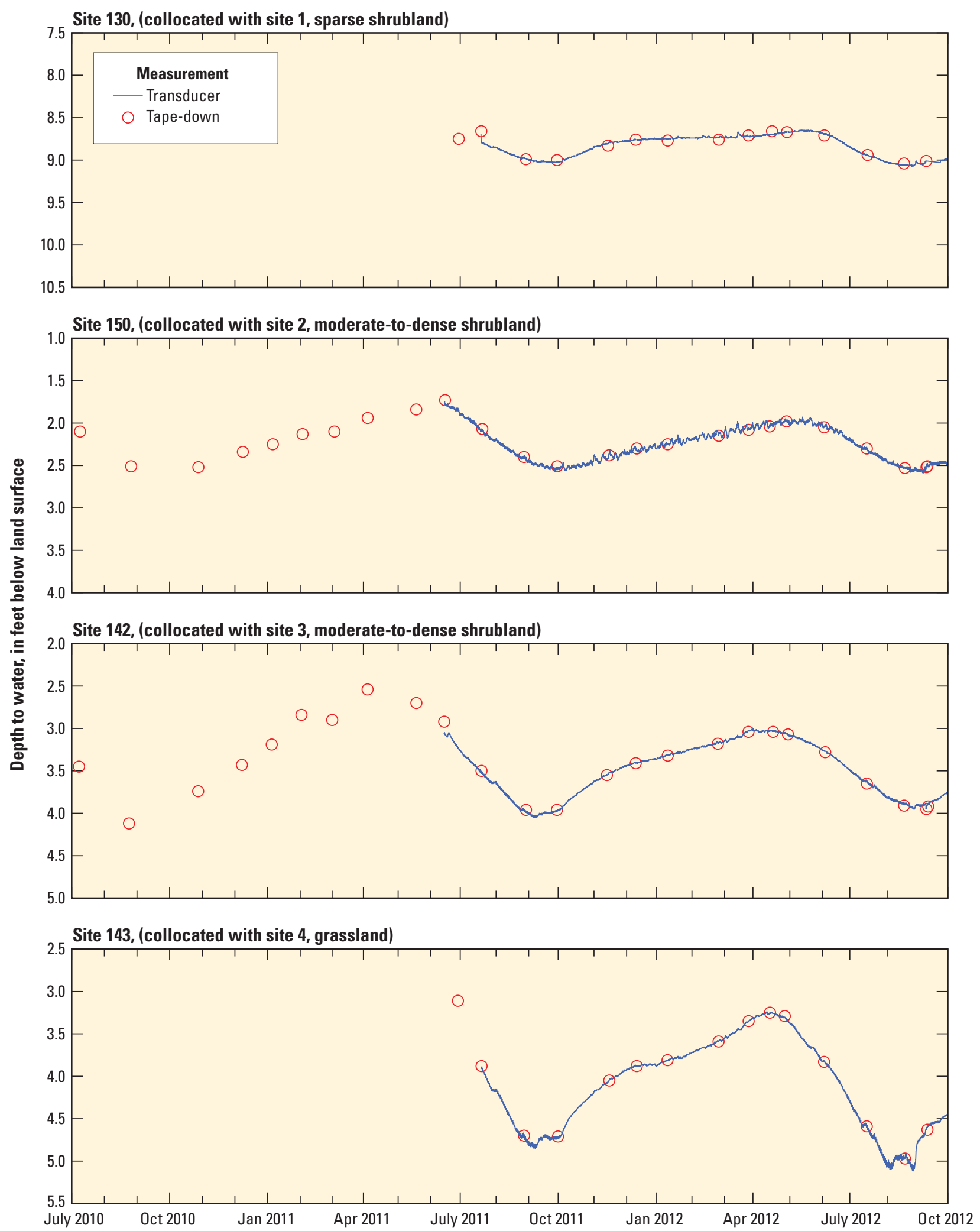

Figure 13. Wells collocated with evapotranspiration sites, Kobeh Valley, central Nevada; sites 130, 150, 142, and 143 were collocated with sites $1-4$, respectively. 
received sensor readings 10 times per second and computed means, variances, and covariances every 30 minutes. The hygrometer and sonic anemometer were positioned about 4 in. apart, directed into the prevailing wind direction (west), and deployed at about $5 \mathrm{ft}$ or more above the plant canopy (table 9).

Net radiation was measured with a net radiometer (NR Lite, Kipp and Zonen) deployed at about $8 \mathrm{ft}$ or more above the plant canopy (table 9). Soil-heat flux was measured using the calorimetric method (Fuchs, 1987) and two heat-flux plates (HFP01, Hukseflux), eight averaging soil-temperature probes (TCAV, Campbell Scientific, Inc.), and a water-content reflectometer (CS616, Campbell Scientific, Inc.). Heat-flux plates were installed at 3.1-in depths, with replicate temperature probes placed above it at 0.8- and 2.4-in depths. The water-content reflectometer was installed horizontally, and it integrated measurements between two horizontal rods at 0.8and 2.4-in depths. Flux plate, temperature, and water-content sensor spatial locations were chosen so the mean degree of shading from vegetation approximated the degree of shading across each site. The change in soil temperature and soil-water content above heat-flux plates was converted to a heat flux and added to the heat-flux plate measurements (Fuchs, 1987) to compute soil-heat flux at the soil surface. Available energy was computed as net radiation minus soil-heat flux.

Precipitation was measured at each site with a National Weather Service approved standard 8-in diameter volumetric rain gauge (NovaLynx). A tipping-bucket rain gauge (TE525, Campbell Scientific, Inc.) was collocated with each volumetric rain gauge to record the timing and intensity of rainfall events. The precipitation accumulated in volumetric gauges was measured monthly. Volumetric rain gauges were drained seasonally, wiped dry, and refilled with a half-inch layer of mineral oil to prevent evaporative losses of the subsequently collected precipitation. During winter, the orifice funnel of the volumetric rain gauge was removed and 5 inches of antifreeze were added in combination with mineral oil (1 inch) to prevent freezing of accumulated water and to quickly melt collected snow. A wind monitor (05106, R M Young Company) also was collocated with and deployed at the same height as rain gauges. Wind-speed data were used to correct precipitation measurements for wind-related undercatch (Yang and others, 1996). Installation heights of all aboveground sensors are listed in table 9 .

Instruments were checked and evaluated monthly and repaired or replaced as necessary. The horizontal level of net radiometers and sonic anemometers was checked and adjusted if necessary, and both the net radiometer and krypton hygrometer were cleaned with distilled water or isopropyl alcohol. Solar panels and precipitation gauge orifices were cleaned of dust and debris, and batteries were refilled with distilled water routinely.

\section{Data Correction and Processing}

Turbulent flux, available energy, and other site-specific data were processed to reduce errors, and data gaps were identified and filled in a manner similar to Moreo and others, 2007; Shoemaker and others, 2011; and Garcia and others, 2014. Gap-filling procedures varied with the variable and the length and timing of the gap. Volumetric water-content measurements taken with CS616 probes were calibrated using soil-moisture measurements collected from soil cores. Raw latent- and sensible-heat-flux data were corrected to compensate for limitations in eddy-covariance theory and equipment design (discussed in the "Turbulent Fluxes" section ). Data were filtered to identify poor-quality data. Precipitation measurements were corrected for wind-related undercatch (Yang and others, 1996).

\section{Turbulent Fluxes}

High-frequency $(10 \mathrm{~Hz})$ latent- and sensible-heat fluxes were processed and corrected using LI-COR's EddyPro ${ }^{\circledR}$ software (www.licor.com/eddypro) and summarized in 30-minute fluxes. Spikes in the datasets representing more than six times the standard deviation for a given 30-minute averaging period were removed and replaced with the running mean. Coordinate rotation of the 3-D wind components was applied to account for imperfect leveling of the CSAT anemometer, such that its horizontal axis is perpendicular to the mean wind streamline. Frequency response errors resulting from flux losses or attenuation at high (fast) and low (slow) frequencies also were corrected (Moore, 1986; Massman, 2000). Additional corrections to the latent-heat flux included the Webb, Pearman, and Leuning (WPL)-correction (Webb and others, 1980) to account for variations in air density resulting from fluctuating temperature (thermal expansion) and humidity (vapor dilution) and the krypton hygrometer oxygen-sensitivity correction (Tanner and Greene, 1989).

Occasional spikes in turbulent-flux data from electronic and physical noise were censored. Water accumulation on the hygrometer from liquid and solid precipitation, and possibly dew and frost, accounted for a large portion of the physical noise. Data were considered poor and rejected when this was observed. Additional data filtering followed procedures described in Garcia and others (2014).

Table 9. Above-ground sensor heights, in feet, at four evapotranspiration stations, Kobeh Valley, Nevada.

[3D, three-dimensional]

\begin{tabular}{cccccc}
\hline \multirow{2}{*}{$\begin{array}{c}\text { Site } \\
\text { number }\end{array}$} & $\begin{array}{c}\text { CSAT3 3D } \\
\text { sonic } \\
\text { anemometer }\end{array}$ & $\begin{array}{c}\text { KH20 krypton } \\
\text { hygrometer }\end{array}$ & $\begin{array}{c}\text { NR lite net } \\
\text { radiometer }\end{array}$ & $\begin{array}{c}\text { Tipping } \\
\text { bucket rain } \\
\text { gage }\end{array}$ & $\begin{array}{c}\text { Volumetric } \\
\text { rain gage }\end{array}$ \\
\hline 1 & 6.6 & 6.6 & 9.2 & 2.6 & 2.6 \\
\hline 2 & 6.5 & 6.5 & 7.9 & 2.4 & 2.4 \\
3 & 7.1 & 7.1 & 9.2 & 3.9 & 3.9 \\
\hline 4 & 4.9 & 4.9 & 9.6 & 2.6 & 2.6 \\
\hline
\end{tabular}


Data gaps from discarded poor-quality data or sensor malfunction were filled using estimated values based on the time of day, seasonal variability, and gap length. Gaps of 2 hours or less were interpolated for all sensors between previous and subsequent measurements. Air-temperature (HMP45C) data gaps of more than 2 hours were filled using ordinary leastsquares regressions with sonic temperature output from the CSAT anemometer, where available, followed by regressions with air temperature measured at the nearest site using the HMP45C. Gaps in latent- and sensible-heat-flux data of more than 2 hours were filled using the following methods. Nighttime gaps (net radiation less than 5 watts per square meter, $\mathrm{W} / \mathrm{m}^{2}$ ) in the latent-heat flux were set equal to zero unless they followed or preceded a gap in daytime data. Daytime gaps and those lasting several days were filled using multivariate regression between turbulent fluxes and micrometeorological data (Garcia and others, 2014). The proportion of gap-filled latent-heat-flux data ranged from 8 percent at sites 1 and 3 to 21 percent at site 4 . The proportion of gap-filled sensible-heatflux data ranged from 2 percent at sites 1 and 3 to 13 percent at site 4 .

\section{Available Energy}

Net-radiation data measured with the NR Lite sensor were corrected for wind-speed sensitivity. These sensors are calibrated at zero wind speed; therefore, at any other wind speed, the sensor sensitivity decreases (Campbell Scientific, Inc., 2010). All available energy data were filtered during periods when sensors were cleaned and serviced and when datalogger programs were revised. Data gaps typically spanned 2 hours or less and were filled using linear interpolation. Gaps in net radiation and soil-heat flux lasting several hours to days were filled using ordinary least-squares regression with data from an alternate site $\left(\mathrm{r}^{2}\right.$ greater than 0.92$)$. At ET site 4 , the datalogger malfunctioned from late July through August 2011 and from early September through October 2011, causing complete loss of all data during these periods. Available energy data during September through October 2011 ( 9 percent of the available energy record) were gap filled using data from ET site 2 and the multivariate-regression technique (Garcia and others, 2014).

Near-surface water-content measurements collected with the CS616 probe were calibrated against volumetric water content measurements (cubic inch per cubic inch, or $\mathrm{in}^{3} / \mathrm{in}^{3}$ ) of soil samples periodically collected near the CS616 probes. Shallow burial of the CS616 instrument control box (1-2.7-in depths) resulted in thermal loading that was observed as diurnal fluctuations in water content. Therefore, similar to Garcia and others (2014), 30-minute measurements were averaged over 24-hour intervals (from midnight to midnight); the 24-hour average was assigned to the 12:00 PM 30-minute measurement interval; and these values were linearly interpolated from day to day to compute a continuous 30-minute dataset. Calibration equations were based on average daily measurements and had reasonable coefficients of determination, ranging from 0.76 at site 3 to 0.78 at site 1 .

\section{Energy-Balance Ratio}

The fundamental criterion of the conservation of energy is that the energy balance is satisfied, and available energy is equal to the turbulent flux. This concept is commonly referred to as energy-balance closure. The energy imbalance in this study was evaluated over the period of record (water years 2011 and 2012) using the energy-balance ratio (equation 3) and the ordinary least-squares regression of the turbulent flux against available energy (table 10). The energy-balance ratio is the ratio of the turbulent flux to available energy:

$$
E B R=\frac{\lambda E+H}{R_{n}-G}
$$

The energy balance was evaluated using mean turbulent flux and available-energy components in equation (1) computed from 30-minute data over the period of record. Thirtyminute turbulent-flux data were corrected using respective energy-balance ratios (table 10). Daily-average turbulent-flux and available-energy measurements were used in regressions to avoid potential inaccuracies in soil-heat-flux estimates (Leuning and others, 2012). These regressions were forced through a y-intercept of zero. Analyses only included days during which 48 good 30-minute measurements were collected (that is, no data gaps) in order to remove potential day or night time bias (table 10).

Energy-balance ratios ranged from 0.87 at ET site 1 to 0.91 at ET sites 2 and 4 (table 10). Regression slopes comparing turbulent-flux and available-energy measurements were nearly equal to energy-balance ratios and largely explained the variability in the relation between turbulent flux and available energy (coefficients of determination ranged from 0.95 to 0.97).

In this study, measured turbulent fluxes were considered to be a probable minimum. A probable maximum was computed by dividing 30 -minute measured and gap-filled turbulent fluxes by the energy-balance ratio for the respective water

Table 10. Energy-balance ratio (EBR), slope and coefficient of determination from ordinary least squares regressions comparing turbulent flux and available energy measurements, and percent good (non-gap filled) half-hour and daily data at four evapotranspiration sites, Kobeh Valley, Nevada.

[EBR: the energy-balance ratio or ratio of turbulent flux to available energy computed using average turbulent flux and available energy components. Slope; only includes data where 48 good measurements were made over a 24-hour interval in order to remove potential day- or night-time bias. Daily "Good data": indicative of 48 good half-hour measurements during a 24-hour interval]

\begin{tabular}{|c|c|c|c|c|c|}
\hline \multirow{2}{*}{$\begin{array}{c}\text { Site } \\
\text { number }\end{array}$} & \multirow{2}{*}{ EBR } & \multirow{2}{*}{ Slope } & \multirow{2}{*}{$\begin{array}{c}\text { Coefficient of } \\
\text { determination, } \mathrm{r}^{2}\end{array}$} & \multicolumn{2}{|c|}{ Good data (percent) } \\
\hline & & & & Daily & Half hour \\
\hline 1 & 0.87 & 0.87 & 0.96 & 87 & 94 \\
\hline 2 & 0.91 & 0.90 & 0.95 & 65 & 88 \\
\hline 3 & 0.90 & 0.90 & 0.96 & 76 & 93 \\
\hline 4 & 0.91 & 0.90 & 0.97 & 46 & 74 \\
\hline
\end{tabular}


year to achieve full energy-balance closure. This approach maintains the eddy-covariance measured Bowen ratio, or ratio of sensible-to-latent heat flux (Bowen, 1926). The best (most probable) estimate of the latent-heat (evaporative) flux in this study is the mean of the probable minimum and probable maximum estimates. The most probable estimate (Moreo and Swancar, 2013) is referred to as energy-balance corrected ET $\left(\mathrm{ET}_{\mathrm{c}}\right)$ for the remainder of this report.

\section{Precipitation}

Point measurements of precipitation can have deficiencies in catch as a result of wind (Larson and Peck, 1974; Yang and others, 1996; Nešpor and Sevruk, 1999). Using an unshielded precipitation gage similar to those used in this study, Yang and others (1996) determined that undercatch deficiency increases exponentially with wind speed and estimated a 14 percent deficiency at 10 miles per hour for liquid precipitation (rain) and a 65 percent deficiency for solid precipitation (snow). Precipitation measurements were corrected for wind-related undercatch using relations developed for rain, snow, and mixed precipitation by Yang and others (1996). Wind-speed measurements taken at the same height as precipitation collectors were used for corrections when sensors were deployed (sites 2 and 3 during water year 2011 and all sites during water year 2012). Prior to deploying a wind monitor at sites 2 and 3, wind speed at the height of the collector was estimated (1) by relating CSAT3 anemometer measurements to wind-monitor measurements, when available, using ordinary least-squares regression and (2) by adjusting CSAT3 anemometer measurements to the height of the precipitation collector. Coefficients of determination $\left(\mathrm{r}^{2}\right)$ describing regressions at sites 2 and 3 were strong (greater than 0.98 ).

Tipping-bucket precipitation measurements collected over a 30-minute interval were gap-filled and corrected to match monthly volumetric measurements prior to applying undercatch corrections. Volumetric-gauge corrections to tippingbucket measurements increased values by 35 percent at site 1 , 14 percent at site 2, 15 percent at site 3 , and 32 percent at site 4 over the period of record. Wind-related undercatch corrections increased volumetric-corrected tipping-bucket measurements by 19 percent at site 1 , about 12 percent at site 2,12 percent at site 3 , and 18 percent at site 4 over the period of record (table 11). During periods when the tipping-bucket sensor malfunctioned and concurrent measurements of continuous precipitation and wind speed were unavailable, volumetricgauge data were increased for wind undercatch using the geometric mean of corrections taken when all sensors were functioning properly and for precipitation type (liquid, mixed, or snow). Uncertainty associated with using the geometric mean was evaluated using the standard deviation of these corrections and was incorporated into the uncertainty presented in table 12 .

Discrepancies between volumetric gauge and tippingbucket measurements could reflect unrecorded precipitation by the tipping-bucket gauge during small events (where water accumulation in the bucket evaporated before tipping) or unrecorded snowfall by the tipping bucket. Larger discrepancies at sites 1 and 4 than at sites 2 and 3 likely reflected unrecorded snowfall due to wind-removal of the snow overtopping tipping-bucket gauges. Wind speeds at sites 1 and 4 were substantially greater than at sites 2 and 3 (table 11) because the precipitation collector orifices at sites 2 and 3 were positioned closer to the height of the vegetation canopy, where wind is greatly reduced, whereas the collector orifices at sites 1 and 4 were positioned well above the short canopy, minimizing the canopy effects on wind.

Snowfall measurement errors were assumed to minimally affect water-year precipitation measurements because volumetric gauge orifice funnels were removed during winter, and antifreeze was added to the gauges to minimize the amount of snowfall potentially overtopping the collectors. Wind-related undercatch corrections for snowfall, however, could bias estimates, because tipping buckets do not reliably measure snowfall. Snowfall typically accumulates in the tipping-bucket gage orifice while temperatures remain below freezing and is not measured by the tipping-bucket gauge until it is melted. Measurement of this precipitation at a later time and altered wind speed could bias undercatch corrections. Similarly, if snowfall exceeds a few inches before melting, it can overtop tipping-bucket gauges and not be measured, biasing measurements low.

\section{Source-Area Measurements}

Source areas for turbulent-flux and available-energy measurements vary according to instrument height and placement, the component being measured, wind speed and direction, and the vegetation canopy height and roughness characteristics. The source area for eddy-covariance turbulent-flux measurements $(\lambda \mathrm{E}$ and $\mathrm{H})$, often referred to as footprint, is the dynamic

Table 11. Annual mean wind speed measured at two heights, liquid fraction of total precipitation, and measured and corrected precipitation at four evapotranspiration sites, Kobeh Valley, Nevada, 2011 and 2012.

[Sensor heights are reported in table 9. IR, incomplete record]

\begin{tabular}{|c|c|c|c|c|c|c|}
\hline \multirow{2}{*}{$\begin{array}{c}\text { Site } \\
\text { number }\end{array}$} & \multirow{2}{*}{$\begin{array}{l}\text { Water } \\
\text { year }\end{array}$} & \multicolumn{2}{|c|}{$\begin{array}{l}\text { Mean wind speed } \\
\text { (miles per hour) }\end{array}$} & \multirow{2}{*}{$\begin{array}{l}\text { Liquid } \\
\text { fraction of } \\
\text { total } \\
\text { precipita- } \\
\text { tion }\end{array}$} & \multicolumn{2}{|c|}{ Precipitation (inches) } \\
\hline & & $\begin{array}{c}\text { Station } \\
\text { anemometer } \\
\text { (CSAT3) }\end{array}$ & $\begin{array}{l}\text { Precipitation } \\
\text { gage }\end{array}$ & & Measured & Corrected \\
\hline 1 & 2012 & ${ }^{1} 6.4$ & ${ }^{1} 4.3$ & IR & 5.7 & 6.8 \\
\hline \multirow{2}{*}{2} & 2011 & 4.1 & 2.4 & 0.50 & 11.1 & 12.3 \\
\hline & 2012 & 4.9 & 3.0 & 0.55 & 7.1 & 8.0 \\
\hline \multirow{2}{*}{3} & 2011 & 23.9 & ${ }^{2} 2.5$ & IR & 9.6 & 10.7 \\
\hline & 2012 & 4.4 & 3.0 & 0.58 & 5.9 & 6.6 \\
\hline 4 & 2012 & 5.6 & 5.2 & 0.50 & 6.8 & 8.0 \\
\hline \multicolumn{7}{|c|}{$\begin{array}{l}{ }^{1} \text { Values likely are biased because data were unavailable from early June through } \\
\text { September } 2012 \text {. }\end{array}$} \\
\hline${ }^{2}$ Value & $\begin{array}{l}\text { likely a } \\
2011 \text {. }\end{array}$ & biased becaus & se data were un & available fros & October 20 & 10 through \\
\hline
\end{tabular}


Table 12. Measured annual precipitation, energy-balance evapotranspiration $\left(\mathrm{ET}_{\mathrm{c}}\right.$ ), soil-water storage change, groundwater evapotranspiration ( $\mathrm{ET}_{\mathrm{gw}}$ ) and associated uncertainties at four evapotranspiration (ET) sites, Kobeh Valley, central Nevada, 2011-12.

[Date range: dates over which groundwater ET was evaluated. Precipitation: measured precipitation corrected for wind related undercatch. Precipitation uncertainty: includes measurement uncertainty, additive RMS error when wind was not measured at the height of the precipitation collector (2011 data only), and uncertainty associated with using the geometric mean of the undercatch uncertainty when the tipping bucket was offline. ET $\mathbf{T}_{\mathbf{c}}$ : computed as the mean of annual measured ET and the maximum potential ET as detrmined by adjusting annual turbulent fluxes upward to achieve full energy balance closure. ET $\mathbf{c}$ uncertainty: includes gapfilling and systematic uncertainty associated with energy balance closure. Soil-water storage change: applied over the upper 6 inches of soil, assuming that measured near-surface (0.8-2.4 inches below land surface) water content decreased linearly over the upper 6 inches of soil. ET $\mathbf{g w}$ : (Groundwater ET computed as ET minus precipitation plus soil water storage change) divided by the number of years analyzed. ET $\mathbf{g w}_{\mathbf{w}}$ uncertainty: uncertainty represents the square root of the sum of squared precipitation uncertainty, $\mathrm{ET}_{\mathrm{c}}$ uncertainty, and soil water storage measurement uncertainty (less than $0.001 \mathrm{feet}$ ). $\mathrm{mm} / \mathrm{dd} / \mathrm{yyyy}$, month/day/year]

\begin{tabular}{|c|c|c|c|c|c|c|c|c|}
\hline $\begin{array}{c}\text { Site } \\
\text { number }\end{array}$ & $\begin{array}{c}\text { Date range } \\
\mathrm{mm} / \mathrm{dd} / \mathrm{yyyy}-\mathrm{mm} / \mathrm{dd} / \mathrm{yyyy}\end{array}$ & $\begin{array}{l}\text { Precipitation } \\
\text { (feet per year) }\end{array}$ & $\begin{array}{c}\text { Precipitation } \\
\text { uncertainty } \\
\text { (feet per year) }\end{array}$ & $\begin{array}{c}\mathrm{ET}_{\mathbf{c}} \\
\text { (feet per year) }\end{array}$ & $\begin{array}{c}\mathrm{ET}_{\mathrm{c}} \\
\text { uncertainty } \\
\text { (feet per year) }\end{array}$ & $\begin{array}{l}\text { Soil-water } \\
\text { storage change } \\
\text { (feet per year) }\end{array}$ & $\begin{array}{c}\mathrm{ET}_{\mathrm{gw}} \\
\text { (feet per year) }\end{array}$ & $\begin{array}{c}\mathrm{ET}_{\mathrm{gw}} \\
\text { uncertainty } \\
\text { (feet per year }\end{array}$ \\
\hline 1 & $08 / 25 / 2011-08 / 24 / 2012$ & 0.50 & 0.04 & 0.65 & 0.05 & 0.00 & 0.15 & 0.06 \\
\hline 12 & $08 / 28 / 2010-08 / 27 / 2012$ & 0.77 & 0.01 & 1.21 & 0.06 & 0.00 & 0.44 & 0.06 \\
\hline 13 & $08 / 05 / 2010-08 / 04 / 2012$ & 0.66 & 0.04 & 1.45 & 0.08 & 0.01 & 0.80 & 0.09 \\
\hline 4 & $11 / 03 / 2011-11 / 02 / 2012$ & 0.65 & 0.01 & 1.78 & 0.09 & 0.00 & 1.13 & 0.09 \\
\hline
\end{tabular}

${ }^{1}$ Values represent the average of 2 years.

upwind land-surface area contributing to measured water vapor and heat fluxes, whereas that for the available energy measurements (difference between $R_{n}$ and $G$ ) is constant and depends mostly on the net-radiometer height. Turbulent-flux source areas were derived from a dispersion model (Scheupp and others, 1990) and assuming mildly unstable atmospheric conditions. Sensors were mounted at least $5 \mathrm{ft}$ above the average plant canopy to capture the well-mixed and unstable surface layer. Model parameters were determined from vegetative canopy measurements collected during this study and those obtained from Stull (1988). Computed source areas indicated up to 90-percent of the turbulent flux originated from upwind distances of $550 \mathrm{ft}$ at site $1,440 \mathrm{ft}$ at site 2 (fig. 14), $450 \mathrm{ft}$ at site 3 , and $450 \mathrm{ft}$ at site 4 . The relative flux contribution peaked within $30 \mathrm{ft}$ upwind of the sensors and decreased asymptotically thereafter. Source areas for available-energy measurements were small relative to turbulent-flux measurements. The 99-percent net-radiometer source area for downward-facing sensors is a circular area with a radius of 10 times the instrument height (Campbell Scientific, Inc., 2010). Netradiometer source areas extended radially from nearly $80 \mathrm{ft}$ at site 2 to about $100 \mathrm{ft}$ at site 4 , but measurements taken directly beneath or perpendicular to the sensors contributed the bulk of the total measured value. Source areas for ground-heat-flux measurements were very small, less than a 1-ft diameter circle around the sensor.

\section{Site-Level Groundwater Evapotranspiration}

Site-scale ET $_{\text {gw }}$ was computed by subtracting the sum of annual precipitation and change in soil-water storage from total ET at each of the four ET sites. Total ET sources can include a combination of precipitation, groundwater, and surface water. Surface-water drainages in and local surface-water run-on were not observed in the ET measurement areas during the study period. Therefore, site-scale ET measurements were
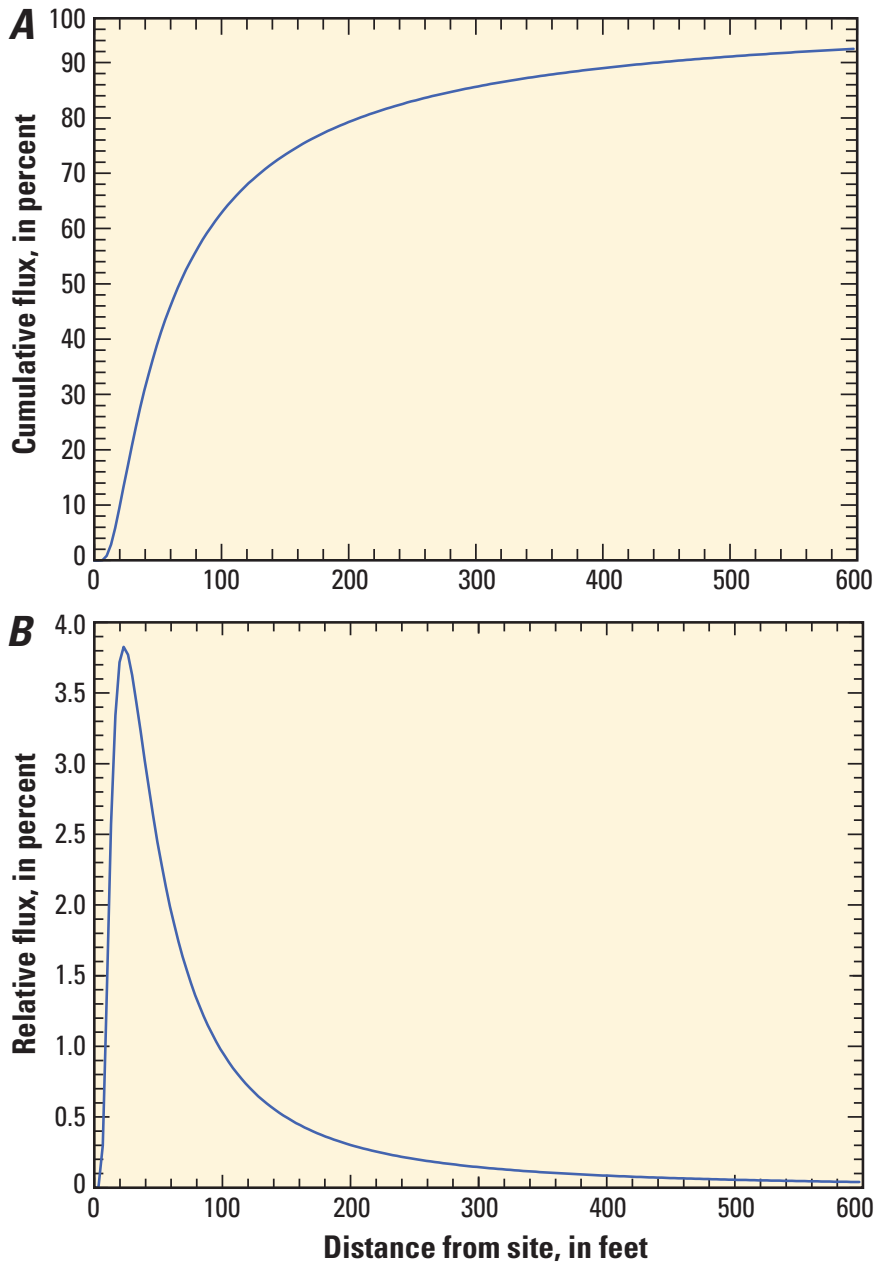

Figure 14. Source-area contributions to turbulent fluxes with distance from site 2, Kobeh Valley, Nevada: $\boldsymbol{A}$, cumulative and $\boldsymbol{B}$, relative measured. 
assumed to represent precipitation and groundwater sources only. Local precipitation at each site was assumed to be removed by ET.

Groundwater ET was estimated for periods when differences in shallow, volumetric soil-water content and storage were small to negligible. Water-content differences between the beginning and end of the water year averaged $0.05 \mathrm{in}^{3} / \mathrm{in}^{3}$ for sites 1-4 and ranged from a minimum of 0 for site 2 in water year 2011 to a maximum of $0.1 \mathrm{in}^{3} / \mathrm{in}^{3}$ for site 3 in water year 2012 (fig. 12). These differences indicated that a small amount of soil moisture from precipitation that fell during the previous water year was not completely removed by ET in the same water year. Late-summer precipitation during water year 2012 largely led to this difference. At sites 2 and 3, $\mathrm{ET}_{\mathrm{gw}}$ was evaluated over a 2-year measurement period, whereas sites 1 and 4 were evaluated over a single year.

Wind-undercatch corrected precipitation measurements totaled $12.3 \mathrm{in}$. at site 2 and $10.7 \mathrm{in}$. at site 3 during water year 2011 (table 11). During water year 2012, corrected precipitation at the four sites ranged from $6.6 \mathrm{in}$. at site 3 to $8.0 \mathrm{in}$. at sites 2 and 4.

Daily $\mathrm{ET}_{\mathrm{c}}$ totals generally followed a seasonal pattern, such that ET typically was greatest during the summer and least during the winter (fig. 15). Energy-balance corrections increased ET measurements by about 8 percent at site 1,6 percent at site 3 , and 5 percent at sites 2 and 4 . At the moderateto-dense shrubland sites (sites 2 and 3), $\mathrm{ET}_{\mathrm{c}}$ exhibited a minor peak in early spring in addition to the major peak in summer. Early-spring peaks were driven by increasing temperatures and predominantly reflect evaporation of soil moisture from cool-season precipitation. The summer peak, which corresponded with plant growth during the summer months at all ET sites, steadily increased until plants reached full growth during mid-summer and declined thereafter. Summertime $\mathrm{ET}_{\mathrm{c}}$ also corresponded with declining groundwater levels (fig. 13). At the sparse shrubland site, site 1, these seasonal patterns were muted because most ET resulted from evaporation of intermittent precipitation.

Potential evapotranspiration (PET) was computed for comparison with $\mathrm{ET}_{\mathrm{c}}$ measurements from the grassland site (site 4; fig. 2; table 2). Potential ET was computed using the Priestley-Taylor model, with an alpha value of 1.26 (Priestley and Taylor, 1972), which assumes that all energy available for evaporation is accessible to the plant canopy (Shuttleworth, 1993). Daily $\mathrm{ET}_{\mathrm{c}}$ rates measured at site 4 during summer 2011 (June-September) averaged about 8 percent less than PET rates, whereas $\mathrm{ET}_{\mathrm{c}}$ rates during summer 2012 averaged about 16 percent less than potential rates (fig. 15). Differences in the ratio of actual to potential ET at site 4 between water years reflect a reduction in water availability, chiefly of water derived from precipitation; annual precipitation was less in water year 2012 than in 2011 (fig. 3; table 2).

Mean annual $\mathrm{ET}_{\mathrm{gw}}$ estimates increased from $0.15 \mathrm{ft}$ at site 1 to $1.13 \mathrm{ft}$ at site 4 (table 12) consistent with increasing vegetation density. At the moderate-to-dense shrubland sites, taller shrub heights at site 3 than site 2 and the presence of bunch grass at site 3 (table 8 ) corresponded to a greater $\mathrm{ET}_{\mathrm{gw}}$ rate $(0.80 \mathrm{ft}$ at site 3 and $0.45 \mathrm{ft}$ at site 2 , table 12). These estimates corresponded with ET measurement-based values from previous studies at shrubland sites, but appeared low with respect to the grassland site. Previous estimates from sparse to dense phreatophytic shrubland areas at similar latitudes and altitudes in Nevada range from less than 0.08 to about 0.76 feet per year (ft/yr), whereas estimates from grassland areas range from about 1.6 to $2.6 \mathrm{ft} / \mathrm{yr}$ (Berger and others, 2001; Moreo and others, 2007). Errors associated with $\mathrm{ET}_{\mathrm{gw}}$ estimates represent a combination of precipitation and $\mathrm{ET}_{\mathrm{c}}$ correction errors (table 12).

\section{Scaling Groundwater Evapotranspiration from Site to Basin Level}

A variety of remote-sensing techniques have been used in groundwater discharge areas to scale point measurements to the basin level (Nichols, 2000; Berger and others, 2001; Moreo and others, 2007; Smith and others, 2007; Laczniak and others, 2008, Allander and others, 2009, Garcia and others, 2014). The amount and rate of water lost to the atmosphere by ET from groundwater discharge areas varies with vegetation type, cover, and structure; precipitation; depth to water; and soil characteristics (Laczniak and others, 1999, 2001, 2008; Nichols, 2000). Satellite imagery, in combination with field mapping, is often used to identify and group areas of similar vegetation and soil characteristics (Laczniak and others, 2001; Moreo and others, 2007; Smith and others, 2007; Garcia and others, 2014). Because ET generally increases with increasing vegetation density and soil moisture, these areal groupings are referred to as ET units because they are assumed to consist of areas with similar ET rates.

Site estimates of groundwater discharge in Kobeh Valley were combined with satellite imagery and PRISM data to scale groundwater discharge from the site to the basin level. Groundwater discharge in the DVFS was estimated by (1) identifying and delineating the GDA; (2) relating a vegetation index calculated from satellite imagery to $\mathrm{ET}_{\mathrm{gw}}$ rates at sites 1-4 in Kobeh Valley and to precipitation-adjusted $\mathrm{ET}_{\mathrm{gw}}$ rates (see the "Estimation of Pre-development Groundwater Evapotranspiration" section) at the sites for all other basins; (3) applying this relation to the spatially continuous vegetation index for vegetated areas in basin-specific GDAs; and (4) applying playa $\mathrm{ET}_{\mathrm{gw}}$ estimates from a previous study to playas in this study. Long-term average annual PRISM precipitation varied among basins in the DVFS.

\section{Satellite Imagery and Vegetation Indexes}

Landsat satellite imagery was used to characterize vegetation cover in the GDA for this study. Landsat is a group of seven Earth-observing satellites, the first of which was launched in 1972, and the most recent in 2013. Each of the Landsat satellites was equipped with one or more sensor instruments designed to collect imagery in several distinct spectral bands in reflective visible and infrared, and emitted 
Site 1, sparse shrubland
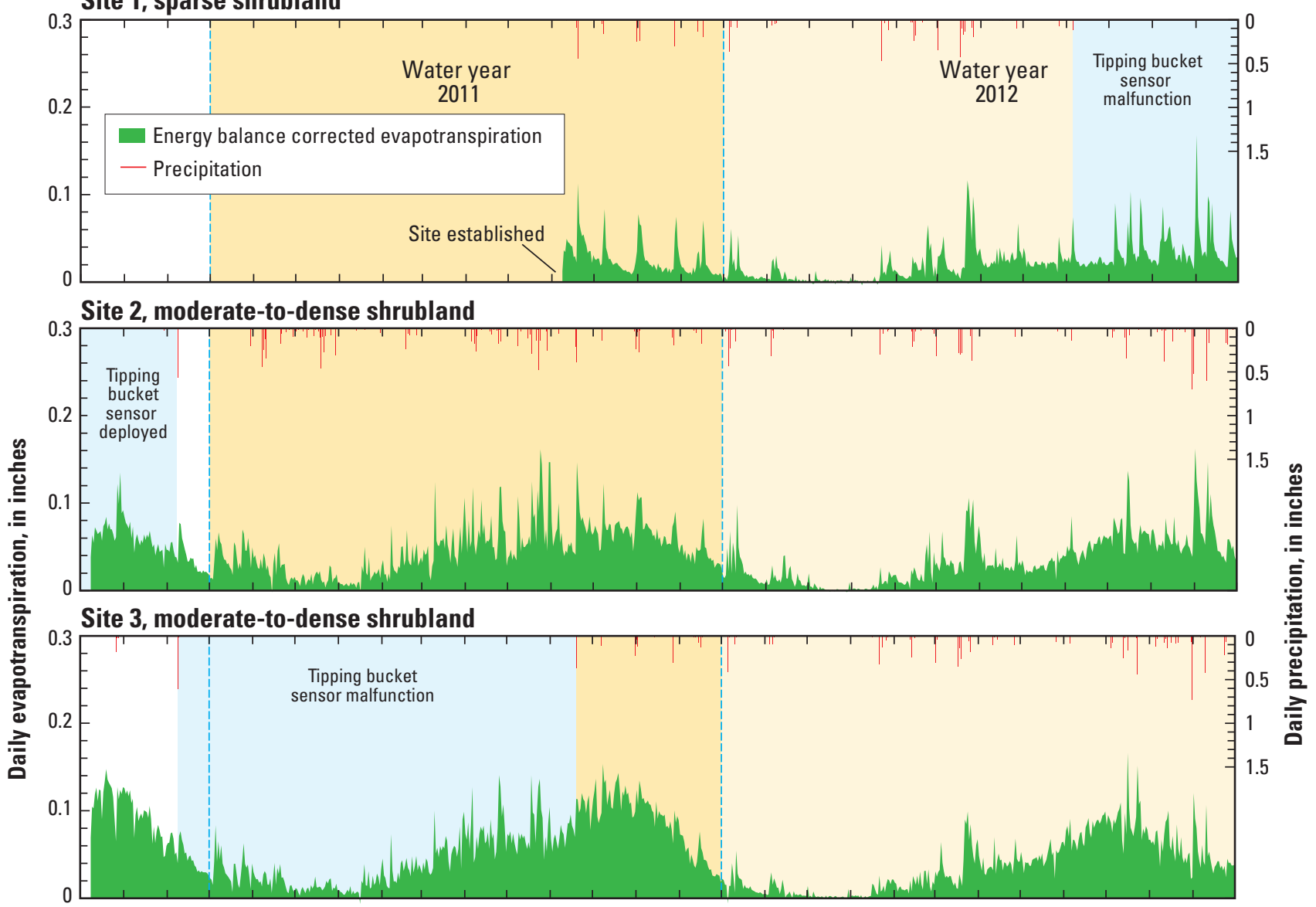

Site 4, grassland

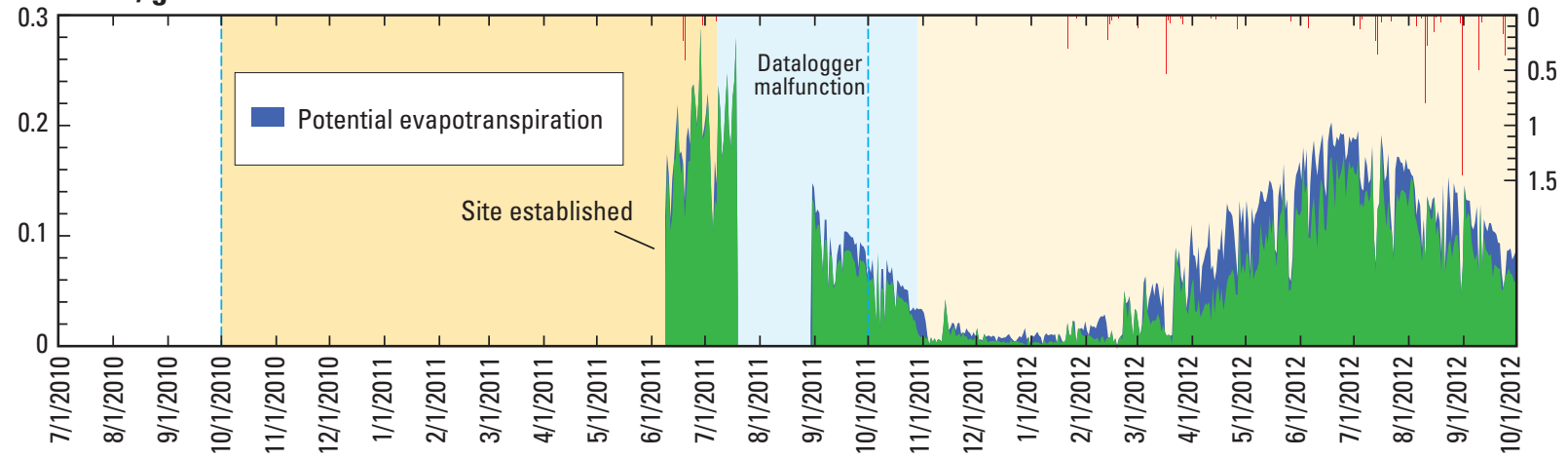

Figure 15. Daily energy-balance corrected evapotranspiration $\left(\mathrm{ET}_{\mathrm{c}}\right)$ and precipitation at four evapotranspiration (ET) sites and the computed potential ET at site 4, October 2010 through September 2012, Kobeh Valley, central Nevada.

thermal wavelengths (U.S. Geological Survey, 2012a). Imagery acquired by the Thematic Mapper (TM) instrument aboard Landsat 5 was used for this study. The TM instrument collects information in six spectral bands, with wavelengths ranging from the visible blue ( 0.45 micrometers, or $\mu \mathrm{m})$ to the shortwave infrared $(2.35 \mu \mathrm{m})$, and in an additional seventh band with thermal infrared wavelengths between 10.4 and $12.5 \mu \mathrm{m}$. Continuous 112-mile-wide swaths of TM imagery are broken into overlapping "scenes" approximately 105 miles in length.
Each scene is imaged by the sensor every 16 days at approximately 100-foot (30-meter) spatial resolution (394-feet, or 120-meters, for the thermal channel) and covers approximately $11,800 \mathrm{mi}^{2}$. Landsat $5 \mathrm{TM}$ scene locations are identified using a world reference system 2 (WRS2) path and row number. The study area is in WRS2 path 41 rows 32 and 33.

Eight scene dates were selected for evaluation against vegetation conditions and measured ET at the four ET sites in Kobeh Valley. Two scenes for each date were required to 
cover the study area (table 13). The selected scenes represented a subset of available images, where skies were cloudfree, vegetation canopies were green and active, and little to no antecedent precipitation was observed at nearby weather stations. All of the scenes were acquired by the Landsat 5 TM sensor during the summer months to represent "growingseason" conditions, when phreatophytes in the GDA are actively transpiring, shrubs have reached maximum growth, but the vigor of early summer annual plants is presumed to be at a minimum. Two scene dates from 2011 were collected to coincide with site-scale ET measurements in the study area. No Landsat scenes were available in 2012 as a result of the failure of the TM sensor aboard Landsat 5 during the late winter of 2012. Six additional scene dates were selected from 2007 through 2010 to provide a larger group of data for evaluation against the site-scale ET data. Each scene was atmospherically corrected by the U.S. Geological Survey Center for Earth Resources Observation and Science (EROS) data center using Landsat Ecosystem Disturbance Adaptive Processing System (LEDAPS) software. The LEDAPS software applies atmospheric corrections to Landsat data to generate a surfacereflectance product. The corrections are based on the Second Simulation of a Satellite Signal in the Solar Spectrum (6S) radiative transfer model used by the Moderate Resolution Imaging Spectroradiometer (MODIS) Land Science Team (U.S. Geological Survey, 2012b). The atmospherically corrected visible, near infrared, and short wave infrared bands for the two scenes for each scene date were mosaicked together to form a single 6-band image covering the study area for each scene date.

Information from multispectral satellite imagery, such as that collected by Landsat $5 \mathrm{TM}$, can be used to characterize vegetation on the basis of light absorption and reflection characteristics unique to vegetated surfaces. Healthy vegetation absorbs light for use in photosynthesis in the red wavelengths collected in TM band $3(0.63-0.69 \mu \mathrm{m})$ and strongly reflects light in the near infrared wavelengths collected in TM band 4 $(0.76-0.90 \mu \mathrm{m})$. Vegetation indices, such as the Normalized Difference Vegetation Index (NDVI; Rouse and others, 1974),

Table 13. Landsat 5 Thematic Mapper scenes evaluated for use in basin-scale estimation of groundwater evapotranspiration, Diamond Valley flow system, central Nevada.

[mm/dd/yyyy, month/day/year; WRS, World Reference System]

\begin{tabular}{ccc}
\hline \multirow{2}{*}{$\begin{array}{c}\text { Image date } \\
\text { mm/dd/yyy }\end{array}$} & \multicolumn{2}{c}{ Landsat image entity identification } \\
\cline { 2 - 3 } & WRS path 41 row 32 & WRS path 41 row 33 \\
\hline 06/30/2007 & LT50410322007181PAC01 & LT50410332007181PAC01 \\
\hline 04/02/2008 & LT50410322008184PAC01 & LT50410332008184PAC01 \\
\hline 04/05/2009 & LT50410322009186PAC01 & LT50410332009186PAC01 \\
\hline $07 / 22 / 2010$ & LT50410322010173PAC01 & LT50410332010173PAC01 \\
\hline $07 / 24 / 2010$ & LT50410322010205EDC00 & LT50410332010205EDC00 \\
\hline $08 / 25 / 2010$ & LT50410322010237PAC01 & LT50410332010237PAC01 \\
\hline $06 / 25 / 2011$ & LT50410322011176PAC01 & LT50410332011176PAC01 \\
\hline 07/12/2011 & LT50410322011224PAC01 & LT50410332011224PAC01 \\
\hline
\end{tabular}

the Modified Soil-Adjusted Vegetation Index (MSAVI; Qi and others, 1994), and the Enhanced Vegetation Index (EVI; Huete and others, 1999), use the contrast between these distinct absorption and reflectance features to help identify vegetated areas and to characterize the health and spatial extent of vegetation communities.

A vegetation index is a unitless single-band image with valid values ranging between -1 and 1 . Index values in vegetated areas are nearly always greater than 0 , and, in general, the healthier and denser the vegetation, the closer the vegetation index value is to 1 . Different vegetation species at 100-percent cover can have different vegetation-index values due to differences in chlorophyll content, internal leaf structure, and canopy structure (Glenn and others, 2008). In combination, these variations can reduce the strength of relationships between the vegetation index and vegetation cover. Vegetation indices that are based on a simple combination of the near infrared and red wavelengths, such as the NDVI, are sensitive to the quantity of green-leaf vegetation in a scene, but also are influenced by the composite background reflectance of the soil surface, plant litter, and woody plant material, particularly in areas of moderate to sparse vegetation cover. The MSAVI and EVI are in a group of vegetation indices that use a canopy background-adjustment factor to reduce the influence of soil and background reflectance on the index and increase the signal from healthy vegetation in the image. The EVI includes an additional correction in the calculation to reduce the effect of atmospheric aerosols on the index.

Multiple vegetation indices were evaluated for their effectiveness at predicting $\mathrm{ET}_{\mathrm{gw}}$, which was assumed to be directly proportional to phreatophytic shrub density. The EVI, MSAVI, and NDVI were calculated from the atmospherically corrected 2007-11 mosaicked summer Landsat 5 Thematic Mapper (TM) scenes (table 13). The area-weighted average vegetationindex values in the source area for each ET site was compared with the estimated groundwater discharge computed from each site (table 14) using ordinary least-squares regression. Area-weighted vegetation-index values for the ET site source areas were determined by computing the pixel mean of the 45-percent and 90-percent contributing areas at each site. The calculation was done by creating two circular buffers around the ET site in a GIS, so each buffer was mapped as a circular area comparable to the computed 45-percent and 90-percent contributing area. The overlap between the two buffers was removed from the 90-percent contributing-area buffer to avoid double accounting of those pixels when calculating the mean vegetation index for each area. Coefficients of determination $\left(\mathrm{r}^{2}\right)$ for all the vegetation indices evaluated were consistently greater than 0.6 , with the exception of two NDVI images (table 14). The EVI regularly exhibited the best coefficients of determination for all images evaluated; therefore, the EVI was selected for the relation-based $\mathrm{ET}_{\mathrm{gw}}$ estimation.

The best coefficients of determination for the EVI data were for the June 2007, August 2010, and August 2011 images. Precipitation records at the Combs Canyon, Coils Creek, and Smoky Valley Carvers weather stations (sites 5, 6, 
and 9; fig. 2; table 2) show that water years 2007, 2008, and 2010 were the driest water years in the 5-year period. Dry years are desirable for evaluation of $\mathrm{ET}_{\mathrm{gw}}$ from phreatophytes using satellite imagery because the remotely sensed signal from active xeric and annual plants and biological soil crusts should be minimized in years when water from precipitation is limited. Water year 2011 was wetter than the 30 -year average annual at all stations where data were available. Although coefficients of determination values for the August 12, 2011, image were good, winter and spring of 2011 were wetter than normal, and early summer images showed pooled water on the Diamond and southern Monitor Valley playas; therefore, summer 2011 images were excluded from further analysis. The July and August 2010 images showed good correlation between measured $\mathrm{ET}_{\mathrm{gw}}$ and $\mathrm{EVI}$ and were the most recent dry scenes available relative to the period of measurement; therefore, these two summer 2010 images were assumed to be adequate to extrapolate $\mathrm{ET}_{\mathrm{gw}}$ across the basin and were selected for all subsequent calculations. The two 2010 scenes were averaged to create a single, summer-mean EVI image for 2010. The EVI images used in subsequent analyses were multiplied by 1000 , and the values converted to integers. These data are referred to as "scaled EVI."

\section{Groundwater Discharge Area}

Groundwater discharge areas typically are characterized by a mix of phreatophytic and xerophytic shrubs, bare soil, and playa. The GDA boundaries represent the margin between xerophytic shrubs that occur outside the boundaries and a mix of xerophytic and phreatophytic shrubs that occur inside the boundaries. In this study, the GDA represents discrete areas in five of the six study area basins (fig. 16). Vegetated areas in the GDA are composed of phreatophytic shrubs with smaller areas of grassland, marshland, xerophytic vegetation, bare soil, and agricultural lands, where phreatophytic shrubs were present historically. The GDA was mapped using techniques similar to those used in studies throughout Nevada and eastern Utah (Nichols, 2000; Laczniak and others, 2001; Smith and others, 2007; Allander and others, 2009; Garcia and others, 2014). National Agriculture Imagery Program (NAIP) imagery from 2010, a digital elevation model (DEM), and water-level data were used in conjunction with field visits to map the GDA at approximately a 1:24,000-scale. During field visits, accessible roads were followed, and the point of transition from predominantly xerophytes to phreatophytes was marked on a digital map using a Global Positioning System (GPS) unit connected to a computer running GIS software. Photographs and notes were taken to document plant and soil conditions present at the marked location. Points, photographs, and notes also were used to document changes in plant communities

Table 14. Coefficients of determination describing relations between vegetation indices and site-scale groundwater evapotranspiration $\left(\mathrm{ET}_{\mathrm{g}}\right)$, Kobeh Valley, Nevada.

[EVI, enhanced vegetation index; ft/yr, feet per year; mm/dd/yyyy, month/day/year; MSAVI, modified soil adjusted vegetation index; NDVI, normalized difference vegetation index]

\begin{tabular}{|c|c|c|c|c|c|c|c|c|c|}
\hline \multirow[b]{2}{*}{ Site number } & \multirow[b]{2}{*}{$\mathrm{ET}_{\mathrm{g}}(\mathrm{ft} / \mathrm{yr})$} & \multicolumn{8}{|c|}{ Mean scaled source area EVI ${ }^{1}$} \\
\hline & & $06 / 30 / 07$ & $07 / 02 / 08$ & $07 / 05 / 09$ & $06 / 22 / 10$ & $07 / 24 / 10$ & $08 / 25 / 10$ & $06 / 25 / 11$ & $08 / 12 / 11$ \\
\hline 1 & 0.15 & 86 & 102 & 108 & 117 & 97 & 95 & 115 & 85 \\
\hline 2 & 0.45 & 114 & 111 & 126 & 113 & 121 & 114 & 124 & 122 \\
\hline 3 & 0.8 & 138 & 150 & 143 & 127 & 163 & 150 & 126 & 155 \\
\hline \multirow[t]{2}{*}{4} & 1.13 & 236 & 253 & 371 & 302 & 294 & 228 & 381 & 291 \\
\hline & $\begin{array}{c}\text { Coefficient of } \\
\text { determination }\left(\mathrm{r}^{2}\right)\end{array}$ & 0.89 & 0.85 & 0.72 & 0.65 & 0.87 & 0.92 & 0.64 & 0.88 \\
\hline Site number & $\mathrm{ET}_{\mathrm{g}}(\mathrm{ft} / \mathrm{yr})$ & \multicolumn{8}{|c|}{ Mean scaled source area MSAVI' } \\
\hline 1 & 0.15 & 73 & 84 & 93 & 99 & 83 & 81 & 98 & 73 \\
\hline 2 & 0.45 & 96 & 94 & 109 & 96 & 102 & 96 & 103 & 101 \\
\hline 3 & 0.8 & 113 & 124 & 120 & 100 & 133 & 124 & 103 & 129 \\
\hline \multirow[t]{2}{*}{4} & 1.13 & 207 & 212 & 320 & 253 & 257 & 202 & 328 & 255 \\
\hline & $\begin{array}{c}\text { Coefficient of } \\
\text { determination }\left(\mathrm{r}^{2}\right)\end{array}$ & 0.85 & 0.85 & 0.71 & 0.62 & 0.84 & 0.88 & 0.62 & 0.86 \\
\hline Site number & $\mathrm{ET}_{\mathrm{g}}(\mathrm{ft} / \mathrm{yr})$ & \multicolumn{8}{|c|}{ Mean scaled source area NDVI ${ }^{1}$} \\
\hline 1 & 0.15 & 114 & 134 & 152 & 159 & 135 & 131 & 161 & 122 \\
\hline 2 & 0.45 & 130 & 132 & 170 & 133 & 142 & 137 & 144 & 146 \\
\hline 3 & 0.8 & 146 & 171 & 189 & 130 & 180 & 178 & 144 & 191 \\
\hline 4 & 1.13 & 306 & 330 & 521 & 409 & 397 & 319 & 513 & 426 \\
\hline & $\begin{array}{c}\text { Coefficient of } \\
\text { determination }\left(\mathrm{r}^{2}\right)\end{array}$ & 0.75 & 0.76 & 0.69 & 0.52 & 0.75 & 0.80 & 0.57 & 0.79 \\
\hline
\end{tabular}

${ }^{1}$ Scaled EVI, MSAVI, and NDVI are the result of multiplying the calculated vegetation index by 1,000 and then rounding to the nearest integer. 


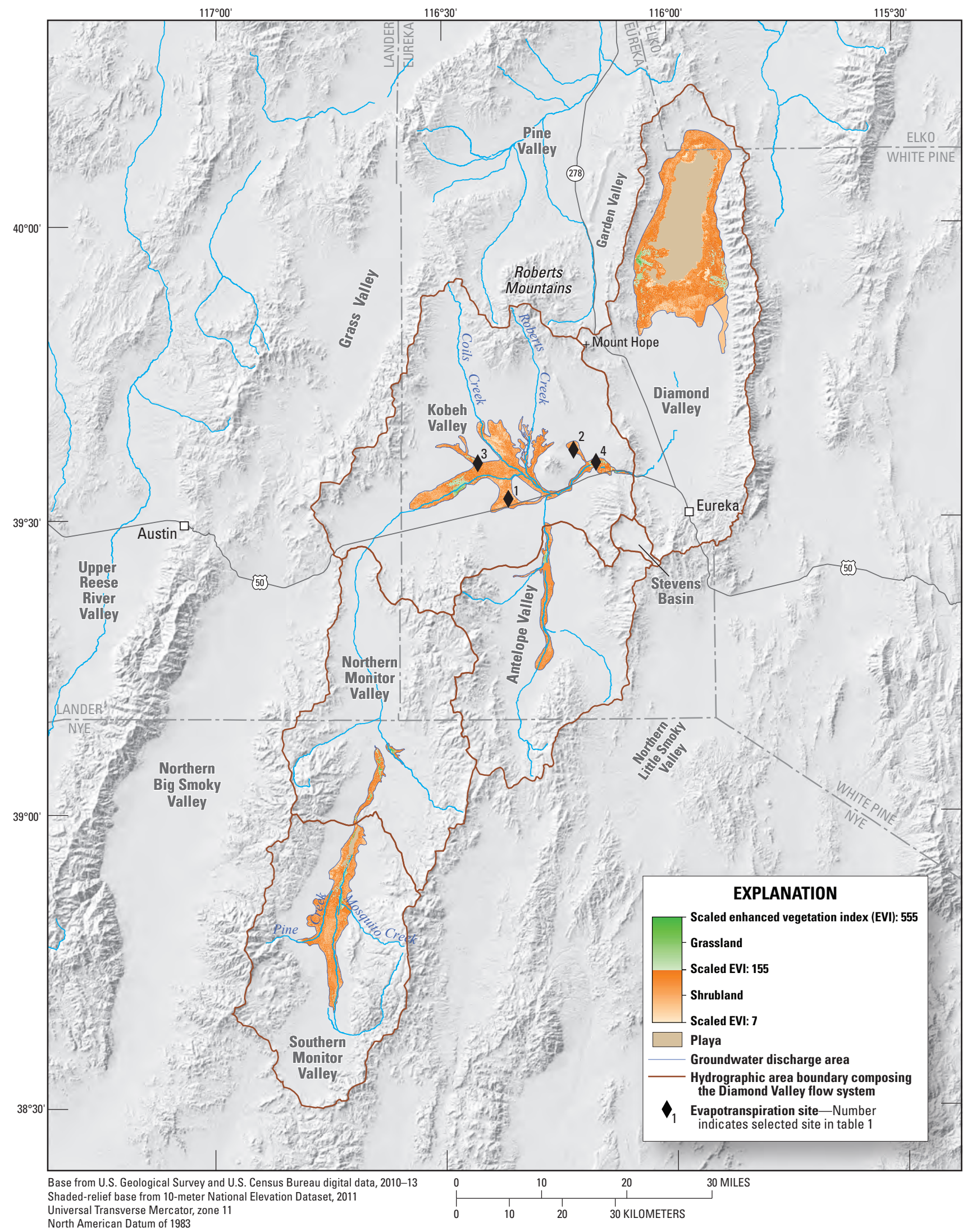

Figure 16. Groundwater discharge area, evapotranspiration units, and variation in the scaled summer-mean 2010 Enhanced Vegetation Index (EVI), Diamond Valley flow System, central Nevada. 
inside the mapped GDA boundary. Each valley was visited and mapped in a similar manner, and the final GDA boundary in each valley was digitized into a GIS. The boundary was generalized and smoothed using ancillary datasets, including 2010 NAIP imagery and DEM data, in areas with limited physical access. The GDA boundary encompasses approximately 118,600 acres in Diamond Valley; 47,500 acres in Kobeh Valley; 10,300 acres in Antelope Valley; and 5,400 and 31,700, acres in northern and southern Monitor Valleys, respectively. Digital GIS data representing the GDA are described in appendix 1.

The GDAs and ET units were delineated by Harrill (1968) for Diamond Valley and by Rush and Everett (1964) for Kobeh, Antelope, and northern and southern Monitor Valleys (figs. 17A-C). The GDA delineations in Antelope and Monitor (north and south) Valleys compared well with the boundary mapped for this study (table 15; figs. $17 \boldsymbol{B}, \boldsymbol{C}$ ); the GDA delineation in Diamond and Kobeh valleys differed more substantially from the boundary in this study. Some areal differences between the recent and historic boundaries are likely due to the scale of mapping and the more recent availability of high resolution aerial imagery, which aided mapping playa boundaries with greater precision in this study than previously.

This study mapped approximately 19,700 more acres of vegetated land and 7,200 fewer acres of playa in Diamond Valley. The GDA delineated for this study included an area of low-density phreatophytes on the southern border of the Diamond Valley GDA that was not included in Harrill's 1968 delineation (fig. 17A). Field observations during recent mapping (fig. 17A) showed low-density greasewood and rabbitbrush intermixed with sage south of the 1968 boundary. The sage predominated along small elevation rises throughout the area. Similar conditions existed in areas of Kobeh Valley not included in the Rush and Everett (1964) GDA delineation (fig. 17B). This study mapped approximately 19,100 more acres of vegetation than was mapped by Rush; including

Table 15. Groundwater discharge areas by vegetation type and groundwater-evapotranspiration (ET) rates from previous investigations and this study, Diamond Valley flow system, central Nevada.

[NA, not applicable]

\begin{tabular}{|c|c|c|c|c|c|}
\hline \multirow[b]{2}{*}{ Basin } & \multirow[b]{2}{*}{ ET unit } & \multicolumn{2}{|c|}{ Previous estimates } & \multicolumn{2}{|c|}{ Recent estimates (2011-12) } \\
\hline & & Area (acres) & $\begin{array}{l}\text { Annual groundwater ET } \\
\text { (acre-feet per acre) })^{1}\end{array}$ & Area (acres) & $\begin{array}{l}\text { Area-weighted mean } \\
\text { annual groundwater ET } \\
\text { (acre-feet per acre) }\end{array}$ \\
\hline \multirow{4}{*}{ Southern Monitor Valley } & Shrubland & \multirow{2}{*}{230,000} & \multirow{2}{*}{0.3} & 27,580 & 0.29 \\
\hline & Grassland & & & 2,752 & 0.89 \\
\hline & Playa & 2,500 & 0.1 & 1,396 & 0.05 \\
\hline & Total & 32,500 & NA & 31,728 & NA \\
\hline \multirow{3}{*}{ Northern Monitor Valley } & Shrubland & 5,100 & 0.2 & 4,017 & 0.37 \\
\hline & Grassland & 800 & 1.25 & 1,340 & 0.98 \\
\hline & Total & 5,900 & NA & 5,357 & NA \\
\hline \multirow{3}{*}{ Antelope Valley } & Shrubland & 11,000 & 0.2 & 9,869 & 0.40 \\
\hline & Grassland & 1,600 & 1.25 & 439 & 1.03 \\
\hline & Total & 12,600 & NA & 10,308 & NA \\
\hline \multirow{4}{*}{ Kobeh Valley } & \multirow{2}{*}{ Shrubland } & ${ }^{3} 10,000$ & 0.2 & \multirow{2}{*}{43,873} & \multirow{2}{*}{0.30} \\
\hline & & ${ }^{4} 12,000$ & 0.4 & & \\
\hline & Grassland & 6,500 & 1.25 & 3,659 & 0.94 \\
\hline & Total & 28,500 & NA & 47,532 & NA \\
\hline \multirow{5}{*}{ Diamond Valley } & Shrubland & 50,000 & 0.3 & 69,066 & 0.29 \\
\hline & \multirow{2}{*}{ Grassland } & 54,650 & 1.2 & \multirow{2}{*}{6,746} & \multirow{2}{*}{0.83} \\
\hline & & ${ }^{6} 1,500$ & 3 & & \\
\hline & Playa & 50,000 & 0.1 & 42,766 & 0.05 \\
\hline & Total & 106,150 & NA & 118,578 & NA \\
\hline All basins & Total & 185,650 & NA & 213,503 & NA \\
\hline
\end{tabular}

${ }^{1}$ Values in Southern Monitor Valley, Northern Monitor Valley, Antelope Valley and Kobeh Valley are from Rush and Everett (1964). Values in Diamond Valley are from Harrill (1968).

2 Rush and Everett (1964) combines greasewood, rabbitbrush, and small areas of saltgrass, and meadow into one unit.

${ }^{3}$ Rush and Everett (1964) splits greasewood and rabbitbrush into two units. This unit represents greasewood, and rabbitbrush.

${ }^{4}$ Rush and Everett (1964) splits greasewood and rabbitbrush into two units. This unit represents greasewood, rabbitbrush, and saltgrass.

${ }^{5}$ Harrill (1968) splits evapotranspiration in areas supported by spring discharge into two units. This unit represents meadowgrass, hay, and some saltgrass.

${ }^{6}$ Harrill (1968) splits evapotranspiration in areas supported by spring discharge into two units. This unit represents wet meadow, marsh, and is normallly flooded; it includes some acreage of alfalfa. 


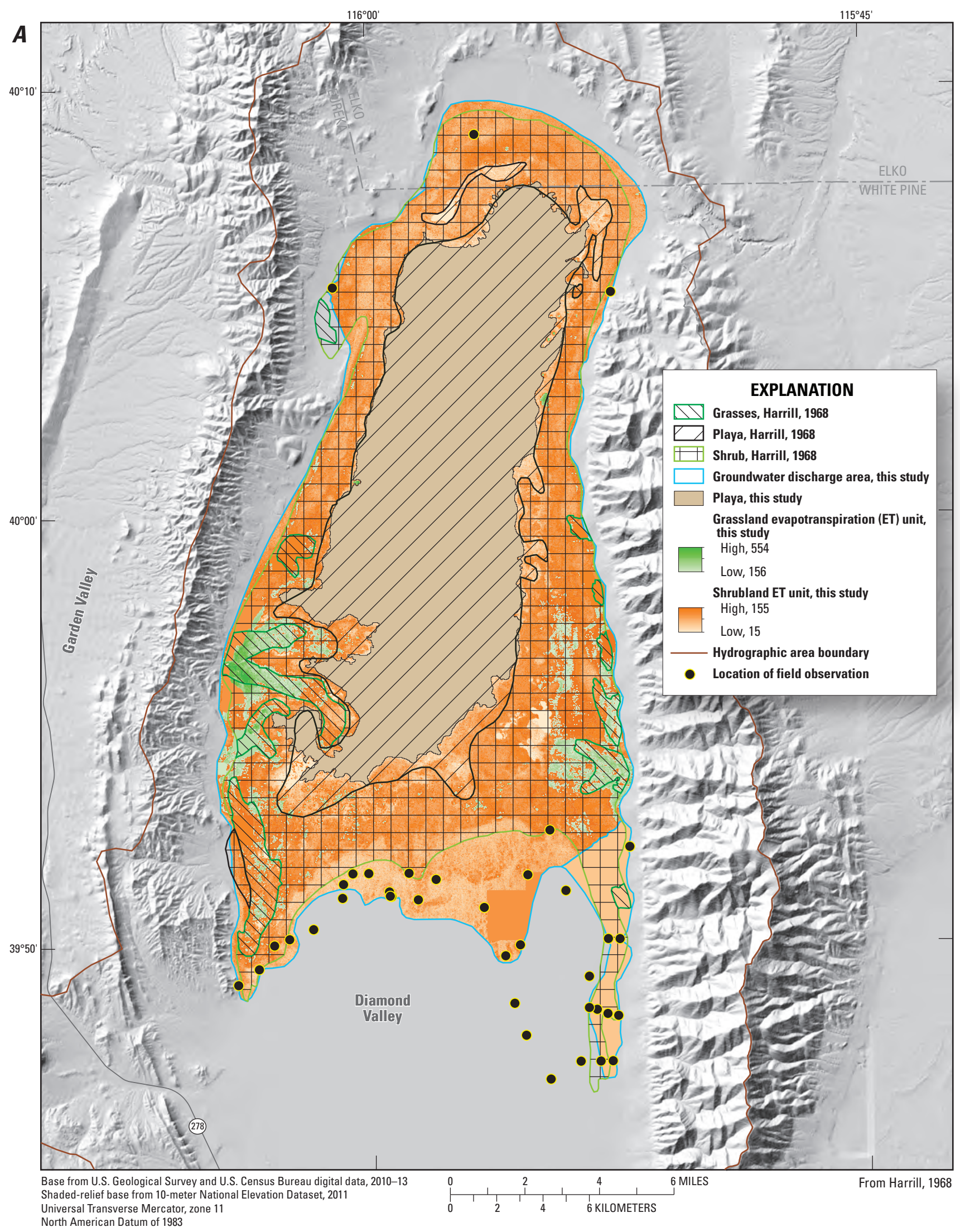

Figure 17. Previous groundwater discharge-area delineations compared with 2011 delineations, Diamond Valley flow system, central Nevada, for $\boldsymbol{A}$, Diamond Valley; $\boldsymbol{B}$, Kobeh and Antelope Valleys; and $\boldsymbol{C}$, northern and southern Monitor Valleys. 


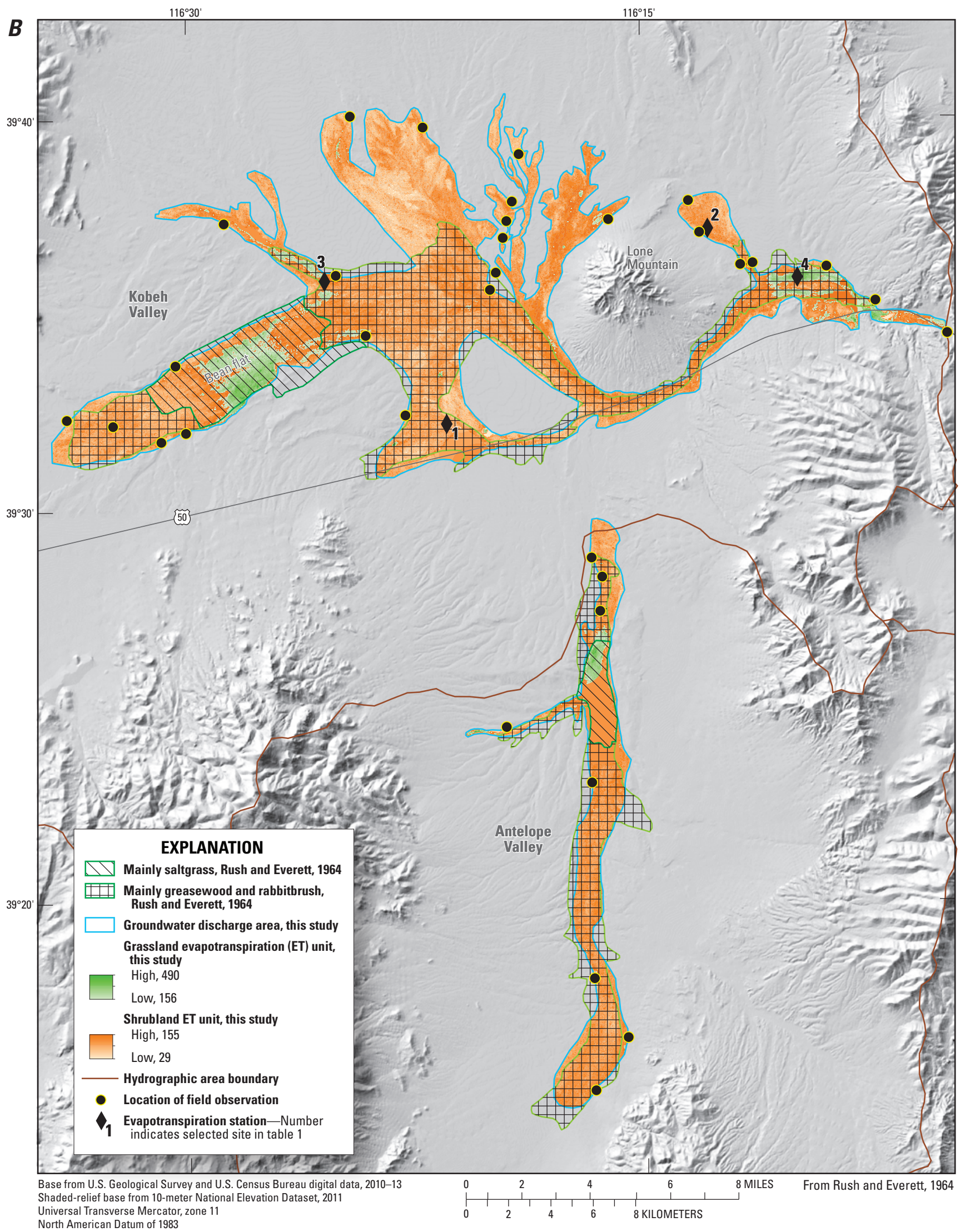

Figure 17. Maps showing previous groundwater discharge-area delineations compared with 2011 delineations, Diamond Valley flow system, central Nevada, for $\boldsymbol{A}$, Diamond Valley; $\boldsymbol{B}$, Kobeh and Antelope Valleys; and $\boldsymbol{C}$, northern and southern Monitor Valleys.Continued 


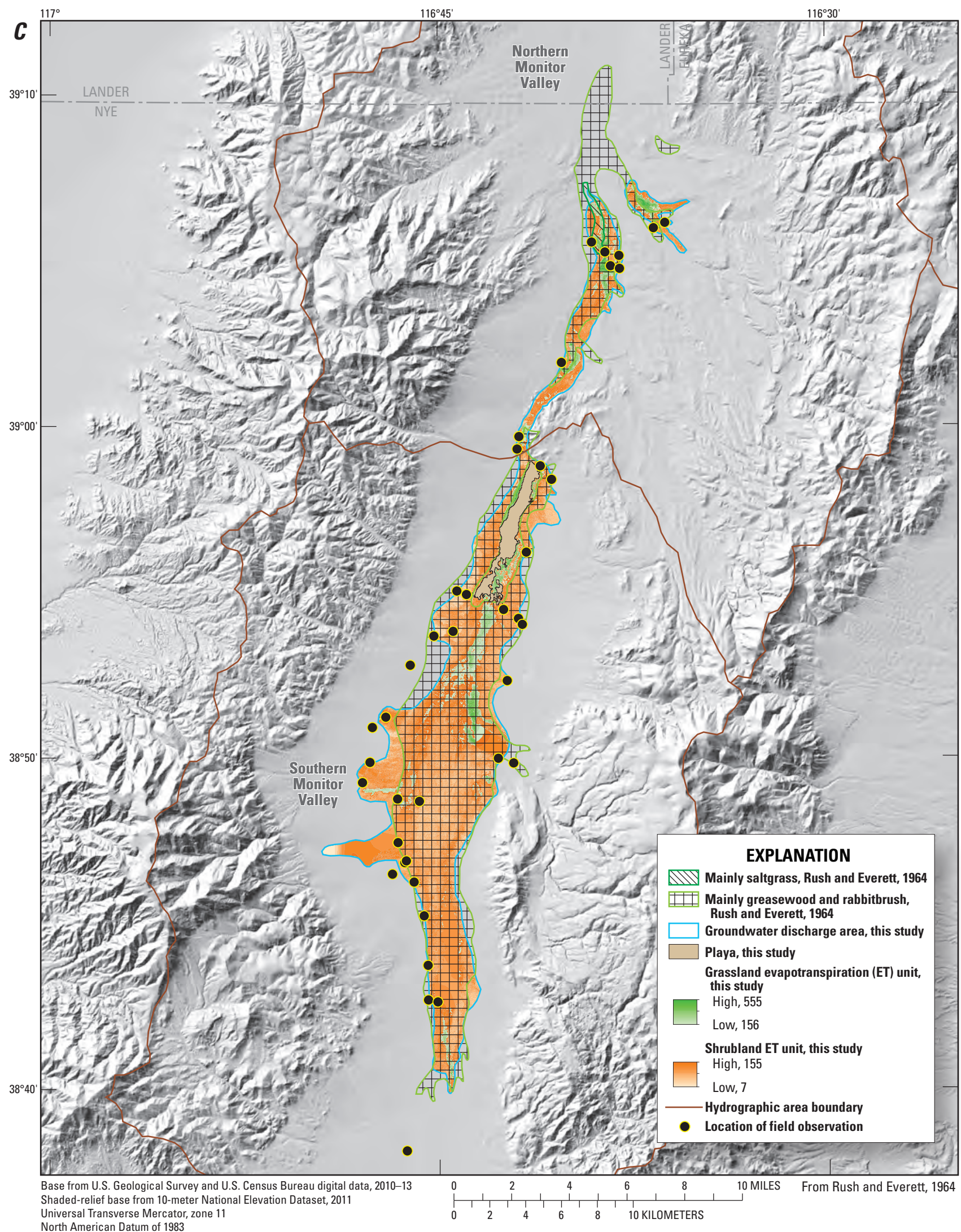

Figure 17. Maps showing previous groundwater-discharge-area delineations compared with 2011 delineations, Diamond Valley flow system, central Nevada, for $\boldsymbol{A}$, Diamond Valley; $\boldsymbol{B}$, Kobeh and Antelope Valleys; and $\boldsymbol{C}$, northern and southern Monitor Valleys.Continued 
about 2,800 fewer acres of grassland and 21,900 more acres of shrubland than previously (table 15). The primary area of mapped grassland in the Rush delineation was around Bean Flat, although 12,000 acres of the total 22,000 acres of shrubland noted by Rush included "greasewood, rabbitbrush, and saltgrass." The greatest difference between the recent and previous delineation was northwest and northeast of Lone Mountain (fig. 17B). The area of GDA northeast of Lone Mountain not mapped by the earlier investigation included ET site 2 in a moderately dense greasewood and rabbitbrush community. The area of GDA northwest of Lone Mountain not mapped in the earlier study was composed of mixed greasewood and rabbitbrush interspersed with sage growing on slightly elevated ridges. The interior of the westernmost lobe of the mapped area was not accessible during field mapping, so it was delineated with less detail than the area nearer to Lone Mountain. Scaled EVI values and field observations in accessible areas indicated that the westernmost lobe was similar to the area in the more detailed delineation to the east. This investigation mapped about 2,300 fewer acres of phreatophytes than the delineation presented in Rush and Everett (1964) for Antelope Valley (fig. 17B). The areal difference comprised nearly equal areas of grassland and shrubland. Rush included an area influenced by a flowing well as grassland that was removed for the estimate of predevelopment-discharge presented in this report. Other differences can be attributed to scale and small differences in the boundary extents. This study mapped 540 fewer acres of vegetated area in northern Monitor Valley, where the GDA boundary for this investigation was mapped to the south of the boundary presented in Rush and Everett (1964; fig. $17 \mathrm{C}$ ). The greatest boundary difference in southern Monitor valley was between the playa boundary mapped in 1964 and in the recent delineation. This study mapped 332 acres more total vegetated area (grassland and shrubland) in southern Monitor Valley than was mapped previously.

\section{Characterization of the Pre-development Landscape}

Water-resources management in Nevada typically relies on pre-development groundwater budgets that are representative of hydrologic conditions prior to substantial groundwater development. Estimation of pre-development groundwater discharge in the DVFS required that vegetated areas disturbed by recent or historic agriculture and other human activities in the GDA and EVI image be delineated and replaced with historic EVI values. Vegetation index values in disturbed areas were replaced with values from surrounding, undisturbed areas. This was done either by passing a sequence of averaging filters to move smoothed undisturbed data from the perimeter of the disturbed area to the interior or by replacing disturbed area pixels with the mean undisturbed shrubland or grassland value for a particular basin. Disturbed areas were delineated using a combination of NAIP and Landsat 5 TM imagery. Irrigated agriculture and meadows surrounding flowing wells were identified and delineated from Landsat scenes and 2010 NAIP imagery. Areas where natural springs had been diverted for agricultural use were evaluated in different ways. An irrigated, center-pivot field at Bailey Spring (site 54; fig. 2; table 4) in Diamond Valley was delineated, and the mean grassland EVI value was applied to the area. Agricultural areas to the north and south of Shipley Hot Spring (site 56; fig. 2; table 4) were delineated, and the mean shrubland EVI value was applied to the disturbed area. Areas of healthy vegetation from spring or spring irrigation runoff west of Bailey and Shipley Hot Spring were not delineated because it was assumed that healthy, native vegetation would grow around natural spring-discharge areas. Areas in the southern Monitor Valley GDA, where Mosquito Creek and Pine Creek were diverted for irrigation, were delineated, and filtered, historic EVI values from the surrounding area replaced ones used previously. The Mosquito Creek disturbed area covered 483 acres, and the Pine Creek area covered 1,143 acres. In Antelope Valley, an area influenced by a flowing well was delineated, and the mean shrubland EVI value for Antelope Valley was applied to that area. Other areas in the GDA exhibiting anthropogenic disturbance, such as grazing, were delineated and EVI values were replaced with filtered values from neighboring, undisturbed areas.

Since the mid-1960s, numerous springs, mostly along the western margin of the playa in the northern part of Diamond Valley, have declined in flow or have stopped flowing entirely. Exact timing of the spring-flow decline is mostly unknown. Limited flow measurements at Taft-Thompson Spring (site 53; fig. 2; table 4), along the eastern margin, and Shipley Hot Spring (site 56; fig. 2; table 4), along the western margin, indicated notable flow declines from the mid-1980s to early 1990s. Spring-flow measurements collected in 1965-68 at five major springs (sites 53-57; fig. 2; table 4) in northern Diamond Valley ranged from 0.6 to $6.8 \mathrm{cfs}$. In 2011-12, only Shipley Hot Springs continued to flow, but at nearly half of the flow rate measured in 1990.

Active agriculture accounted for 7,034 acres of the total, and the residual 746 acres represented rectangular or oddly shaped disruptions in the natural vegetation visible in the NAIP imagery. All disturbances unrelated to active agriculture were in Diamond Valley and likely reflected abandoned agricultural lands, abandoned dwellings, or livestock enclosures. Of the recent disturbance, 2,854 acres were in Diamond Valley, 1,049 acres in Kobeh Valley, 1,305 acres in Antelope Valley, and the remaining 1,826 acres were in southern and northern Monitor valleys.

The southeastern lobe of the GDA in Diamond Valley exhibited elevated EVI, owing to cheat grass and other annuals; therefore, EVI values in this area were replaced. Comparisons between field observations and EVI values indicated that the very sparsely distributed shrubs did not reflect observed EVI values, which were greater than the mean value for the shrubland ET unit. Considering that vegetation in this area was very sparse and that neighboring vegetation was composed of xerophytes, approaches for EVI substitution used for other anthropogenically disturbed areas were unsuitable. In order to accurately characterize the very sparse density of the vegetation canopy and compute a representative $\mathrm{ET}_{\mathrm{gw}}$ rate, EVI values in this area were replaced with the mean EVI of 
very sparse areas in the Diamond Valley shrubland ET unit (89). Very sparse areas were delineated as pixels falling in the lower 25th percentile of the shrubland ET unit, or pixels with a scaled EVI value below 99.

Reductions in spring discharge and $\mathrm{ET}_{\mathrm{gw}}$ due to groundwater withdrawals could not be evaluated with satellite imagery. Greater spring discharge prior to groundwater development likely supported larger areas of healthy vegetation. Landsat imagery used to characterize vegetation density in this study was available only from 1984 to 2011, whereas groundwater development and spring diversions began in the early 1960s. Although historic aerial photographs could provide estimates of the pre-development area supported by springs, comparable vegetation index values and $\mathrm{ET}_{\mathrm{gw}}$ rates were unknown; therefore, changes in spring flow between pre-development measurements in the 1960s and measurements or observations from this study were accumulated and incorporated into predevelopment $\mathrm{ET}_{\mathrm{gw}}$ estimates.

The spring-flow decline was determined by comparing a simple average of measurements taken in the mid-1960s with winter measurements taken from 2010-12. Negligible spring discharge decline between the mid-1960s and early 1990s indicated either that the springs were not yet affected by groundwater withdrawals or that spring discharge was composed of local precipitation and regional groundwater flow, such that a decline in spring discharge from groundwater withdrawals was equally compensated for by an increase in precipitation rates during the 1980s. Precipitation rates in the late 1960s were 19 percent (fig. 4) above the long-term mean, whereas rates in the early 1980s were 37 percent above long-term rates. During this study, precipitation rates were below the long-term mean; therefore, if springs are partially influenced by recent precipitation, then discharge rates measured during this study likely reflected a decline in precipitation in addition to declining water levels due to groundwater withdrawals.

\section{Evapotranspiration Unit Delineation}

The GDA was partitioned into three ET units on the basis of field observations, satellite imagery, and mean-scaled EVI values at each of the four ET stations in Kobeh Valley (fig. 16 and 18A): playa, shrubland, and grassland. The playa ET unit in northern Diamond and southern Monitor Valleys (fig. 16) covered 20 percent (about 44,200 acres, table 15) of the study area GDA. The playa ET-unit boundary represents the transition from vegetation to very sparsely vegetated or unvegetated playa and was delineated initially by digitizing the boundary in a GIS using multiple years of EVI data as a guide. The 2010 NAIP and DEM data were then used to evaluate and refine the initial boundary location. The Diamond Valley and southern Monitor Valley playa boundaries encompassed about 42,800 and 1,400 acres, respectively (fig. 19; table 16). Evaluation of summer and winter Landsat images from 2001 to 2011 and precipitation records indicated that the source of intermittent standing water on the playa surface in both valleys was predominantly runoff of direct precipitation on the playa and precipitation-derived surface water run-on. Digital GIS data representing the ET units are described in appendix 1.

Shrubland and grassland ET units were defined between the playa and GDA boundaries in Diamond and southern Monitor Valleys and for the entire GDA in all other basins. The shrubland ET unit was defined as the 2010 summer mean-scaled EVI values greater than zero and less than or equal to the value in the contributing area of site 3 (153; fig. 18A). Scaled EVI values greater than 156 were classified as grassland. Scaled EVI values at site 3 were assumed to represent the upper extent of shrubland density and to define the transition between shrubland and grassland ET units. The mean-scaled EVI value at site 3 corresponded well with field observations of the shrubland-to-grassland transition zone for all the HAs evaluated. Vegetated areas, based on ET unit delineations, covered 79 percent (about 169,000 acres) of the GDA (fig. 16). The shrubland ET unit covered 91 percent (about 154,000 acres) of the vegetated areas, and the grassland ET unit, which was composed both of grass and marsh areas, covered 9 percent (about 14,900 acres) of the vegetated areas. The ET unit delineations were assessed using visual inspection of a combination of Landsat TM images, NAIP imagery, and field-reconnaissance notes and photographs. These delineations reflect general spatial changes on the landscape and were not intended to be exact delineations of plant communities or soil conditions.

\section{Estimation of Pre-development Groundwater Evapotranspiration}

Pre-development $\mathrm{ET}_{\mathrm{gw}}$ was extrapolated across the flow system using relations between $\mathrm{ET}_{\mathrm{gw}}$ rates from this study and the pre-development mean-scaled EVI in vegetated areas and between playa $\mathrm{ET}_{\mathrm{gw}}$ rates from Garcia and others (2014) and ET unit acreages in playa areas. Groundwater ET from native, undisturbed vegetation was assumed to vary minimally from year to year; therefore, $\mathrm{ET}_{\mathrm{gw}}$ estimates from undisturbed sites in Kobeh Valley were considered to be representative of regional long-term rates.

Relations developed between scaled EVI and site-scale $\mathrm{ET}_{\mathrm{gw}}$ estimates were guided by water and energy limitations. The relation for the water-limited shrubland ET unit, where annual ET is mostly derived from precipitation, was assumed to follow a steep linear trend relative to the water- and energylimited grassland ET unit, where ET is mostly derived from shallow groundwater (Garcia and others, 2014). Two separate relations were developed for shrubland and grassland ET units using scaled EVI data from the 2010 summer-mean image. Shrubland areas were characterized by the ordinary least-squares regression between $\mathrm{ET}_{\mathrm{gw}}$ and $\mathrm{EVI}$ at shrubland sites (sites 1-3). Grassland areas were characterized by linear interpolation between $\mathrm{ET}_{\mathrm{gw}}$ and EVI at sites 3 and 4 and extrapolating this line beyond site 4 (fig. 18). In Kobeh Valley, the relations were applied to spatially continuous pre-development distributions of scaled EVI to estimate $\mathrm{ET}_{\mathrm{gw}}$ 

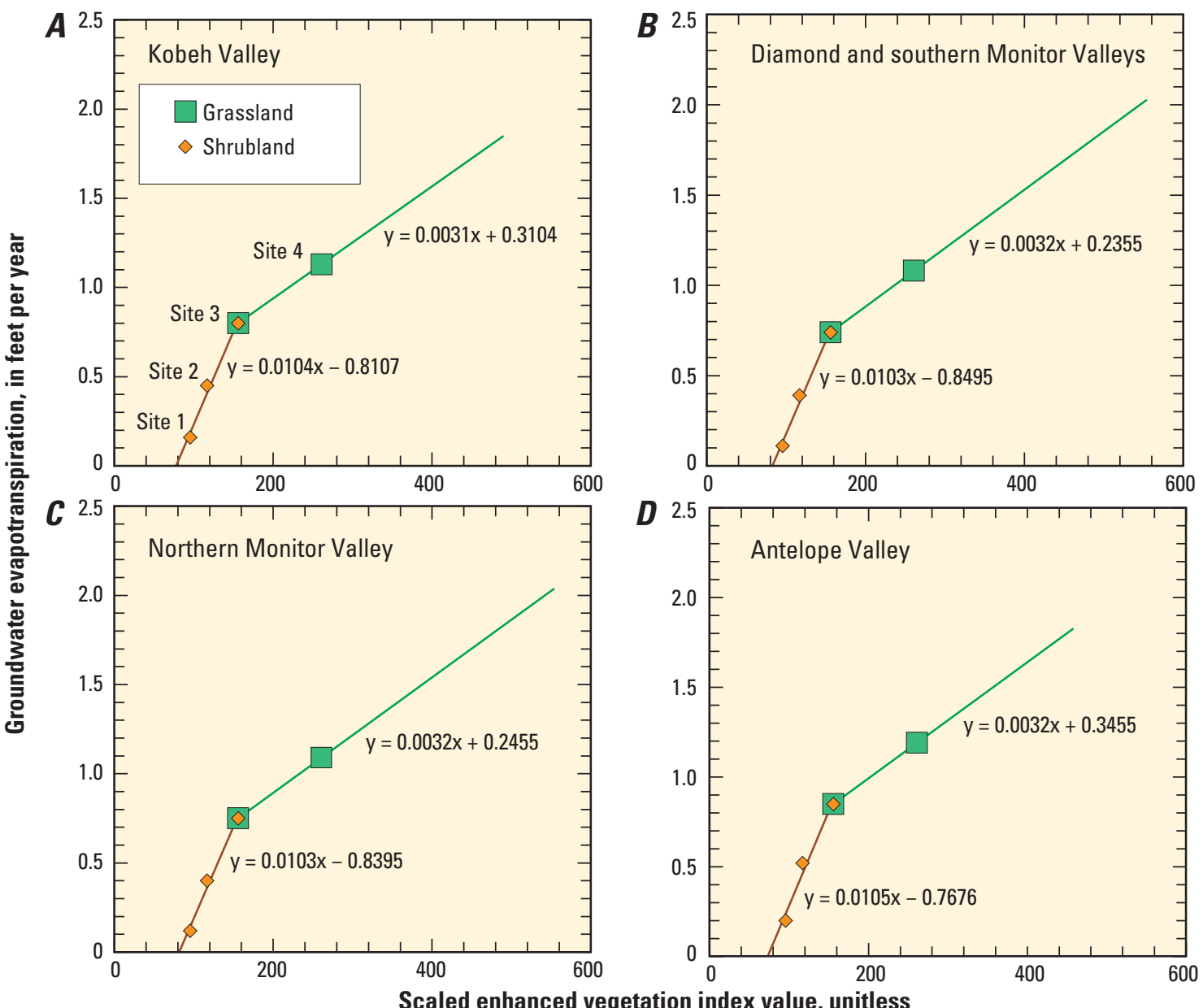

"Scaled EVI" is equal to calculated EVI multiplied by 1,000 and converted to intege

Figure 18. Relations between 2011-12 groundwater evapotranspiration and the scaled Enhanced Vegetation Index (EVI) for shrubland and grassland evapotranspiration units for the summer-mean 2010 image, Kobeh Valley, central Nevada. In Kobeh Valley, groundwater evapotranspiration rates were estimated directly; in all other valleys, rates were adjusted for precipitation differences.

on a pixel-by-pixel basis. Groundwater ET from shrubland pixels that have EVI values less than those at site 1 (averagescaled EVI of 96) and from grassland pixels that have EVI values greater than those at site 4 (average-scaled EVI of 261) were extrapolated from the shrubland and grassland relations, respectively. The total area extrapolated beyond the shrubland and grassland relations totaled 31,000 and 1440 acres, respectively, or 15 and less than 1 percent of the total GDA for the DVFS, respectively.

Basin-scale $\mathrm{ET}_{\mathrm{gw}}$ in Diamond, Monitor Valley (northern and southern part), and Antelope Valley was estimated using relations between precipitation-adjusted $\mathrm{ET}_{\mathrm{gw}}$ rates at sites 1-4 in Kobeh Valley and EVI. Groundwater ET in a basin generally decreases as phreatophyte density decreases or as precipitation increases. For example, Moreo and others (2007) determined that annual $\mathrm{ET}_{\mathrm{gw}}$ differed among three sites in three separate basins in eastern Nevada, where vegetation type and density were similar. Differences in annual $\mathrm{ET}_{\mathrm{gw}}$ corresponded to differences in annual precipitation, where $\mathrm{ET}_{\mathrm{gw}}$ decreased from site-to-site as precipitation increased. Long-term, average annual-precipitation rates varied among basins in the Diamond Valley flow system; therefore, $\mathrm{ET}_{\mathrm{gw}}$ rates were assumed to vary with precipitation among basins for a given phreatophyte density. The 30-year (1981-2010) average annual PRISM precipitation rates in Diamond, northern Monitor, and southern Monitor Valleys were 8, 6, and 8 percent greater, respectively, than rates in Kobeh Valley, whereas the 30-year average annual-precipitation rate in Antelope Valley was 9 percent less than in Kobeh Valley (fig. 20).

Groundwater-ET rates were adjusted for each basin by increasing or decreasing precipitation totals reported in table 12 by the relative percentage differences in long-term PRISM precipitation and, then, recalculating $\mathrm{ET}_{\mathrm{gw}}$ from scaled precipitation rates (see the "Site-Level Groundwater 
Table 16. Mean annual basin-scale groundwater evapotranspiration (ET) and ET unit area, Diamond Valley flow system, central Nevada.

[Mean-scaled enhanced vegetation index: is the result of multiplying the calculated vegetation index by 1,000 and then rounding to the nearest integer. This value represents the mean of pre-development pixels where areas identified as anthropogenically disturbed were replaced with values representing the native landscape. Mean Annual Groundwater Evapotranspiration: Values determined using relations shown in figure 18 and the summer mean enhanced vegetation index (EVI) scene shown in figure 16. Values over 1,000 acre-feet are rounded to the nearest 100 acre-feet. Probable uncertainty: Determined in Kobeh Valley for vegetated ET units as the sum of up-scaling and site-based estimation uncertainties. Upscaling uncertainty was determined as the standard deviation between estimates determined from July and August 2010 scenes, whereas site-based estimation uncertainty was estimated by adding and subtracting the groundwater ET uncertainty from site-scale groundwater ET rates (table 12) used to scale measurements to the basin level. In addition to uncertainty accumulated for Kobeh Valley, maximum probable uncertainty in other basins incorporated an assumed 10 percent uncertainty for applying rates measured in Kobeh Valley. NA, not applicable]

\begin{tabular}{|c|c|c|c|c|c|c|}
\hline Basin & ET unit & Area (acres) & $\begin{array}{l}\text { Mean-scaled enhanced } \\
\text { vegetation index }\end{array}$ & $\begin{array}{c}\text { Area-weighted mean } \\
\text { annual groundwater } \\
\text { evapotranspiration } \\
\text { (acre-feet per acre) }\end{array}$ & \multicolumn{2}{|c|}{$\begin{array}{l}\text { Mean annual groundwater evapotranspiration } \\
\text { (acre-feet) }\end{array}$} \\
\hline \multirow{4}{*}{ Southern Monitor Valley } & Shrubland & 27,580 & 112 & 0.30 & 8,300 & 2,000 \\
\hline & Grassland & 2,752 & 205 & 0.89 & 2,400 & 350 \\
\hline & Playa & 1,396 & NA & 0.05 & 70 & 100 \\
\hline & Total & 31,728 & NA & NA & 11,000 & 2,000 \\
\hline \multirow[t]{2}{*}{ Northern Monitor Valley } & Grassland & 1,340 & 242 & 1.02 & 1,400 & 210 \\
\hline & Total & 5,357 & NA & $\mathrm{NA}$ & 2,900 & 370 \\
\hline \multirow{3}{*}{ Antelope Valley } & Shrubland & 9,869 & 111 & 0.40 & 3,900 & 780 \\
\hline & Grassland & 439 & 211 & 1.02 & 450 & 63 \\
\hline & Total & 10,308 & NA & NA & 4,400 & 780 \\
\hline \multirow{4}{*}{ Diamond Valley ${ }^{1}$} & Shrubland & 69,066 & ${ }^{2} 112$ & 0.30 & 21,000 & 6,000 \\
\hline & Grassland & 6,746 & 186 & 0.83 & 5,600 & 850 \\
\hline & Playa & 42,766 & NA & 0.05 & 2,100 & 2100 \\
\hline & Total & 118,578 & NA & NA & 29,000 & 6,400 \\
\hline All Basins & Total & 213,503 & NA & NA & 64,000 & 7,300 \\
\hline
\end{tabular}

${ }^{1}$ Groundwater-evapotranspiration estimates do not compensate for a reduction in pre-development spring flow and pre-development evapotranspiration of that water by native vegetation.

${ }^{2}$ Mean value determined from the pre-development scene, where pixels with erroneously high values along southeastern lobe of the groundwater discharge area were replaced with values representing very sparse shrubland.

Evapotranspiration" section for $\mathrm{ET}_{\mathrm{gw}}$ computation methodology). For example, in order to develop $\mathrm{ET}_{\mathrm{gw}}$-EVI relations in Diamond Valley, annual precipitation at sites 1-4 (table 12) was increased by 8 percent, and adjusted $\mathrm{ET}_{\mathrm{gw}}$ was computed as annual $\mathrm{ET}_{\mathrm{c}}$ minus adjusted precipitation and the change in soil-water storage. Basin-specific relations between precipitation-adjusted $\mathrm{ET}_{\mathrm{gw}}$ rates at sites 1-4 and EVI (fig. 18) were applied to spatially continuous pre-development EVI values across vegetated ET units in each basin. Reasonable comparisons between measured and PRISM-estimated precipitation rates (30-year, 2011, 2012; table 2; see the "Climate" section) provided confidence in the use of PRISM data to adjust $\mathrm{ET}_{\mathrm{gw}}$.

Groundwater ET from the playa ET unit was computed by multiplying the ET unit area by playa $\mathrm{ET}_{\mathrm{gw}}$ rates from Dixie Valley, NV (Garcia and others, 2014). Playa $\mathrm{ET}_{\mathrm{gw}}$ rates in Dixie Valley were determined from continuous eddy-covariance ET and precipitation measurements collected over 2 years (October 2010-September 2011) at dry and moist playa sites (mean volumetric water contents of 30 and 45 percent, respectively; Garcia and others, 2014). In
Diamond and southern Monitor Valleys, physical properties of the playa material and depth to water are largely unknown, but similar to the Dixie Valley playa, phreatophytes, springs, and seeps along the margin indicate that playa material likely is impermeable with respect to the basin-fill alluvial aquifer and restricts regional groundwater movement and discharge. Therefore, the average $\mathrm{ET}_{\mathrm{gw}}$ rate determined for the Dixie Valley playa $(0.05 \mathrm{ft} / \mathrm{yr})$ was applied.

\section{Groundwater Evapotranspiration Uncertainty}

Uncertainty in basin-scale $\mathrm{ET}_{\mathrm{gw}}$ estimates includes upscaling (from site-to-basin scale) uncertainty, site-based $\mathrm{ET}_{\mathrm{gw}}$ estimate uncertainty, and uncertainty associated with applying $\mathrm{ET}_{\mathrm{gw}}$ rates measured in other basins. Upscaling uncertainty was the standard deviation between estimates determined from July and August 2010 scenes. Site-based estimation uncertainty (or average annual groundwater ET uncertainty; table 12) included precipitation uncertainty, ET estimation uncertainty, and soil-water storage uncertainty. Precipitation 


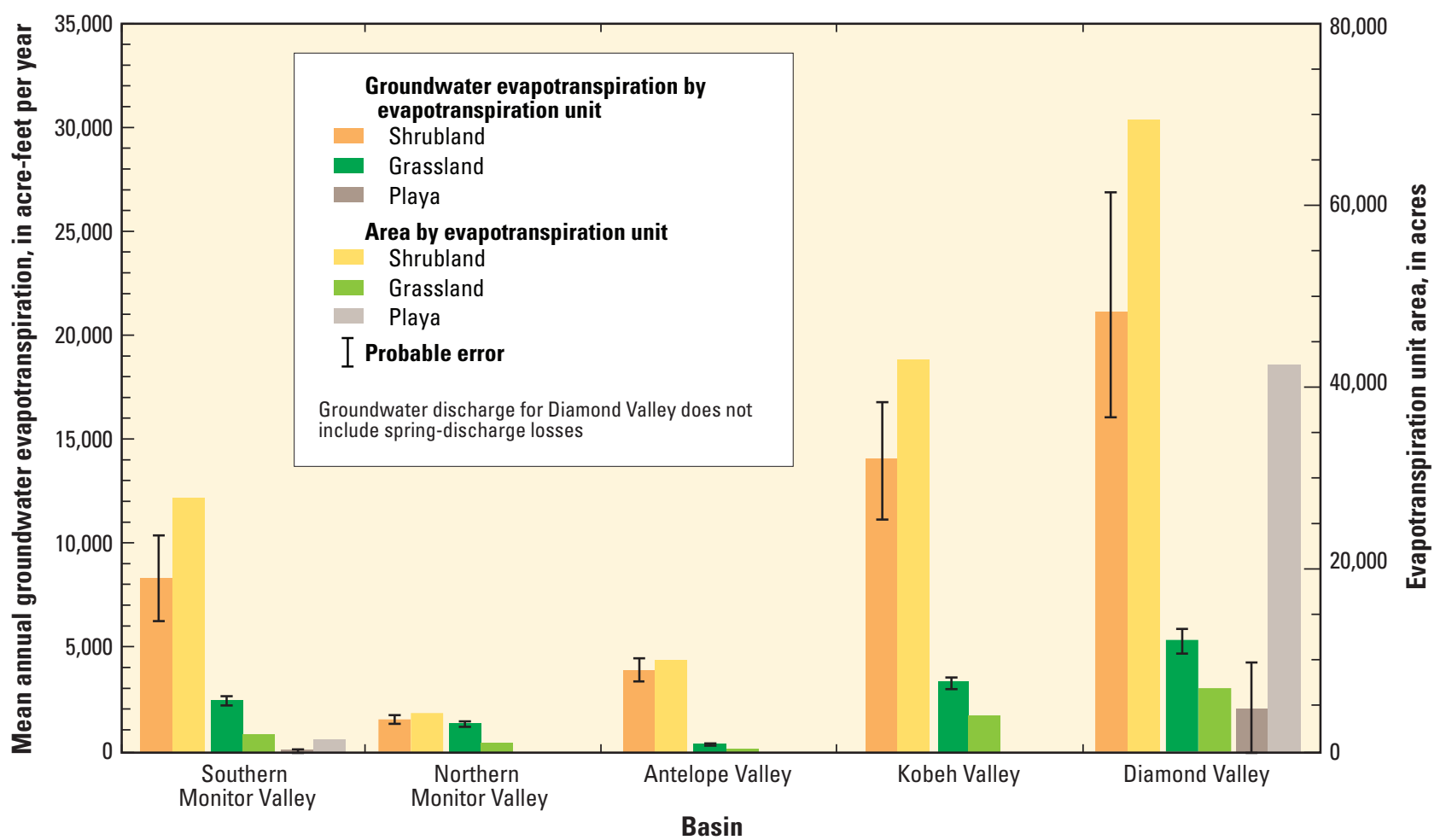

Figure 19. Mean annual basin-scale groundwater discharge from and total area of shrubland, grassland, and playa evapotranspiration (ET) units, Diamond Valley flow System, central Nevada.

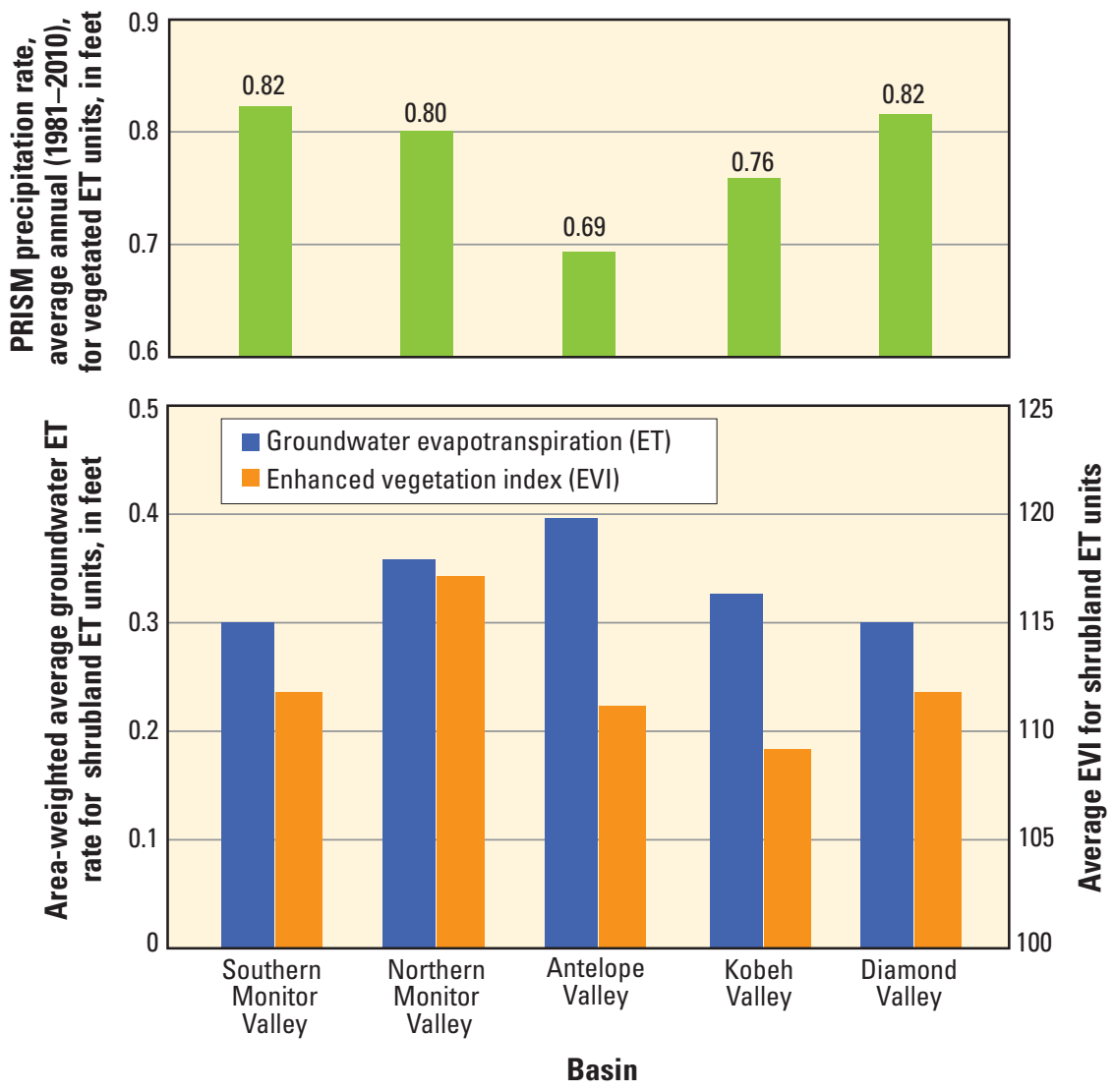

Figure 20. Basin-specific comparisons of average annual PRISM (Parameter-elevation Relationships on Independent Slopes Model) precipitation for 1981-2010 in vegetated ET units, area-weighted average groundwater evapotranspiration (ET) for shrubland ET units, and average scaled enhanced vegetation index (EVI) for shrubland ET units for the 2010 summer-mean image, Diamond Valley flow system, central Nevada. 
uncertainty included measurement uncertainty, additional root mean squared error when wind was not measured at the height of the precipitation collector (2011 data only), and uncertainty associated with using the geometric mean of the undercatch uncertainty when the tipping bucket was offline. Evapotranspiration estimation uncertainty included gap-filling and systematic uncertainty associated with energy-balance closure. Site-based estimation uncertainty was applied by adding and subtracting the total uncertainty from site-scale groundwater ET rates (table 12) used to scale measurements to the basin level.

Uncertainty related to Kobeh Valley site measurements was applied to the entire DVFS and was not modified on the basis of precipitation-adjusted $\mathrm{ET}_{\mathrm{gw}}$ rates. Evapotranspiration from phreatophyte areas in southern and northern Monitor, Antelope, and Diamond Valleys was generally assumed to be similar to measured values in Kobeh Valley on the basis of species combinations and growth patterns observed during field reconnaissance.

The proportion of ET attributed to groundwater often varies with differences in hydrologic conditions, including the precipitation amount, soil texture, aquifer properties, surface morphology, and discharge-area characteristics. For example, $\mathrm{ET}_{\mathrm{gw}}$ estimates could be affected by surface-water contributions in Diamond Valley, elevated vegetation-index values in northern Monitor Valley due to soil background effects, or PRISM-based precipitation adjustments in Antelope Valley. In discharge areas where precipitation is relatively high and the surrounding drainage area is dominated by a steep mountain block, such as the Diamond Range along eastern Diamond Valley, surface-water inflow could be a sizeable component of the ET rate. In northern Monitor Valley, the mean vegetation index for the shrubland ET unit was the greatest of the five discharging basins (by an average of about 6 percent), whereas the surface albedo was the least (by an average of about 5 percent, data not shown). The elevated EVI in northern Monitor Valley could reflect dense phreatophytes or could be influenced by soil background effects from dark, pebble-covered soils unique in the study area to northern Monitor Valley. In Antelope Valley, the mean shrubland $\mathrm{ET}_{\mathrm{gw}}$ rate was greater than all other DVFS basins and was attributed to a lower ( 9 percent) long-term average PRISM precipitation rate than was estimated for Kobeh Valley. Although long-term precipitation measurement sites on the valley floor of these two basins were not available, similar altitudes for basin GDAs and a decreasing precipitation trend from north to south (Harrill, 1968) supports a lower precipitation rate in Antelope Valley. The effects of these varying hydrologic conditions on $\mathrm{ET}_{\mathrm{gw}}$ rates are unknown. Therefore, differences in $\mathrm{ET}_{\mathrm{gw}}$ among basins were assumed to be primarily driven by estimated vegetation density and precipitation patterns, and the effects of other hydrologic conditions were not considered. A minimum uncertainty of 10 percent was added to $\mathrm{ET}_{\mathrm{gw}}$ estimates for southern and northern Monitor, Antelope, and Diamond Valleys to account for potential variations in basin-specific hydrologic conditions in Kobeh Valley and the effects of these conditions on $\mathrm{ET}_{\mathrm{gw}}$ rates.
Uncertainty related to extrapolation of $\mathrm{ET}_{\mathrm{gw}}$-EVI relations beyond the range in EVI characterized by sites $1-4$ was small and well within the probable $\mathrm{ET}_{\mathrm{gw}}$ uncertainty of more than 12 percent. Shrubland areas with EVI values less than those at site 1 totaled about 31,000 acres, or 15 percent of the total GDA, but $\mathrm{ET}_{\mathrm{gw}}$ from these areas was only 5 percent of the total from the GDA. Similarly, grassland areas with EVI values greater than those at site 4 totaled 1440 acres, or less than 1 percent of the GDA, and $\mathrm{ET}_{\mathrm{gw}}$ from these areas was about 3 percent of the total from the GDA. The maximum $\mathrm{ET}_{\mathrm{gw}}$ estimated from the grassland relation was $2.04 \mathrm{ft} / \mathrm{yr}$ in northern Monitor Valley (fig. 16C). This value was slightly less than the net irrigation-water requirements for managed irrigated agriculture in this basin (2.3-4 ft/yr; Huntington and Allen, 2010).

\section{Groundwater Withdrawals}

Most groundwater withdrawals in the DVFS are used for irrigation of agricultural lands in Diamond Valley and Kobeh Valley. Crop inventories in Diamond Valley date back to 1950; the 1950-65 data were compiled by Harrill (1968), and the 1966-2012 data were compiled from NDWR records (fig. 21; Adam Sullivan, Nevada Division of Water Resources, written commun., March 3, 2014). Minor areas of likely irrigation in southern Monitor Valley and Antelope Valley were estimated by remote-sensing techniques (2005-11).

Most groundwater withdrawals in the DVFS were from the southern part of Diamond Valley and were used for growing alfalfa. Harrill (1968) assumed that net pumpage, or the volume of pumped groundwater consumed by ET following irrigation, was about 75 percent of gross pumpage. Residual groundwater, computed as the difference between gross and net pumping, either infiltrates the ground surface and recharges the shallow aquifer system or contributes to runoff (tail water) from irrigated areas that is later consumed by ET in down gradient areas. Since 1966, the NDWR has assumed gross pumpage was 3.0 acre-feet per acre (acre-ft/ acre) throughout the DVFS and that about 10 percent of the gross pumpage potentially returned to the groundwater system (Rick Felling, Nevada Division of Water Resources, written commun., July 24, 2014). This yielded a net groundwater withdrawal rate of 2.7 acre-ft/acre, which is similar to the net irrigation water requirement for alfalfa developed by Huntington and Allen (2010). In areas where the depth to groundwater is about 50 to $100 \mathrm{ft}$, much of the infiltrated water probably is retained in the unsaturated zone and does not reach the water table or takes several decades to reach the saturated zone or water table. In this study, net groundwater withdrawals were estimated as the product of the irrigated acreage and a net pumpage rate of 2.7 acre-ft/acre per year for 1966-2012 in Diamond Valley and for 2006-12 in Kobeh Valley.

Estimates of net groundwater withdrawals in southern Monitor and Antelope Valleys for 2005-11 also were calculated as the product of irrigated acreage and the 2.7 acre- $\mathrm{ft} /$ acre net pumpage rate (Rick Felling, Nevada Division of Water Resources, written commun., July 24, 2014). Minor 


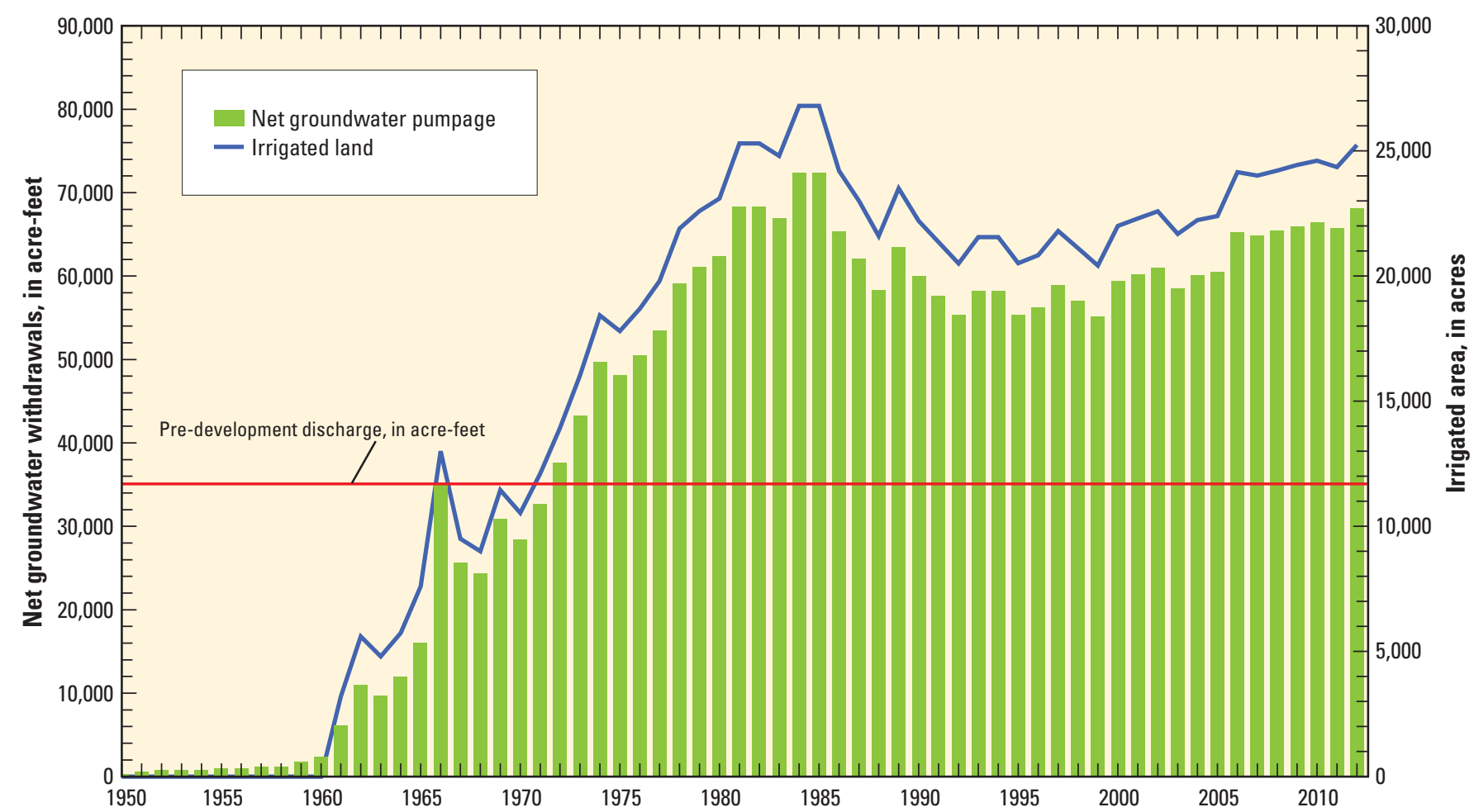

Figure 21. Estimated net groundwater withdrawals from pumping, pre-development natural discharge, and irrigated-acreage for 1950-2012 in Diamond Valley, central Nevada.

irrigated areas in these valleys were estimated from summertime satellite imagery and remote-sensing techniques. Reasonable agreement between remotely sensed irrigated areas estimated in Kobeh Valley and Diamond Valley and those areas reported by NDWR provided verification of the remotesensing techniques applied in southern Monitor and Antelope Valleys.

\section{Groundwater Recharge}

Groundwater recharge from precipitation is the largest component of inflow to DVFS, and, between 1949 and 2011, it was estimated using several methods, including the Maxey-Eakin method (Eakin and others, 1951), the Basin Characterization Model (BCM; Flint and Flint, 2007; Heilweil and Brooks, 2011), and a water-balance relation (this study). The Maxey-Eakin method consists of an empirically derived relation between precipitation and recharge at the basin scale (Maxey and Eakin, 1949). Recharge percentages for selected precipitation zones were developed by balancing recharge and estimated natural groundwater discharge for individual basins. The recharge percentages were mathematically coupled to precipitation distributions developed by Hardman (1936) and Hardman and Mason (1949). The Maxey-Eakin method was designed to estimate basin-scale recharge, which both includes in-place recharge from precipitation and infiltration from streamflow; however, the method does not include subsurface inflow from adjacent basins.
The BCM recharge model (Flint and Flint, 2007) was developed to provide regional consistency among annual estimates of potential recharge from precipitation (in place) and runoff. The BCM is a distributed-parameter water-balance accounting model that uses a compilation of regionally scaled and spatially distributed input data to determine the components and processes necessary to solve the water-balance equation on a grid with a 270 -meter cell size. Details on the approach to solve the water-balance equation are presented in Flint and Flint (2007) and Masbruch and others (2011). In general, the BCM identifies areas, on the basis of favorable climatic and geologic conditions, where precipitation potentially becomes in-place recharge or runoff. The BCM defines in-place recharge as the volume of precipitation available after runoff that percolates past root zones and becomes net infiltration. The BCM provides estimates of runoff and the areas where runoff originates, but does not determine the volume of runoff that becomes recharge.

Heilweil and Brooks (2011) used the BCM (Flint and Flint, 2007) to estimate groundwater recharge from precipitation in the DVFS. This study was part of a regional assessment of groundwater availability, driven by a national water census, in which a conceptual model and numerical steady-state model of the Great Basin Carbonate and Alluvial Aquifer System (GBCAAS) were constructed (Heilweil and Brooks, 2011; Brooks and others, 2014). The GBCAAS is an update of the earlier RASA study (Harrill and others, 1983, 1988; Prudic and others, 1995), and as in the RASA, 
no additional hydrologic data were collected. As an important element of the overall conceptual model, new groundwater budgets were developed that used recharge estimated from the BCM. Groundwater budgets based, in part, on the new recharge estimates were reported for 17 regional flow systems, including the DVFS (Masbruch and others, 2011). The GBCAAS assessment assumed that the fraction of runoff that became recharge ranged from 10 to 30 percent, depending on the amount of surface-water irrigation in a selected basin (Masbruch and others, 2011).

In the DVFS, recharge to the groundwater system from precipitation was minimally affected by groundwater development and was assumed to be relatively constant over time. Under steady-state conditions and limited groundwater development, inflow, derived from precipitation and subsurface inflow, equals outflow, derived from groundwater ET and subsurface outflow. For this study, recharge from precipitation is equivalent to the sum of $\mathrm{ET}_{\mathrm{gw}}$ and net subsurface outflow (subsurface outflow less subsurface inflow).

\section{Subsurface Flow}

Water-level data indicated that net subsurface outflow or interbasin flow in the DVFS goes though the basin-fill aquifer from southern to northern Monitor Valley, from northern Monitor Valley to Kobeh Valley, from northern Antelope Valley to Kobeh Valley, and a minor amount of subsurface flow from Kobeh Valley to Diamond Valley beneath Devil's gate. Estimates of subsurface flow between basins that make up the DVFS were developed by previous investigators (Rush and Everett, 1964; Harrill, 1968) using Darcy's Law. Although these flow estimates were only for the basin-fill aquifer, additional subsurface flow could occur in underlying carbonate or volcanic rocks (Tumbusch and Plume, 2006). The hydrologic properties used to determine the quantity of flow were transmissivity, effective width of the flow section between the basins, and the hydraulic gradient across the flow section.

Subsurface flow through the basin-fill aquifer between hydrographic areas was re-evaluated in this study using previous transmissivity estimates, groundwater-flow sections derived from remotely sensed imagery, and hydraulic gradients determined from the 2012 water-level data. Transmissivity estimates from Rush and Everett (1964) and Harrill (1968) range from 6,700 square feet per day $\left(\mathrm{ft}^{2} / \mathrm{d}\right)$ to $13,400 \mathrm{ft}^{2} / \mathrm{d}$. The flow sections were revised using GIS analyses and recent water-level contours (plate 1). The revised flow cross section between southern and northern Monitor Valleys was $3.1 \mathrm{mi}$ wide and was 3.4 mi wide between northern Monitor Valley and the western part of Kobeh Valley, whereas Rush and Everett (1964) estimated widths of $2 \mathrm{mi}$ and $6 \mathrm{mi}$, respectively. Differences between previous and revised flow sections are likely due to use of more accurate maps, additional water-level data, and differences in flow-section locations for the revised flow sections. Water-level gradients from spring 2012 indicated the potential for groundwater flow from northern Antelope Valley to eastern Kobeh Valley, but the geologic structure and depositional history most likely restricts flow through most of the cross section (Rush and Everett, 1964; Tumbusch and Plume 2006). The revised flow section between Kobeh and Diamond Valleys at Devil's Gate (about $100 \mathrm{ft}$ ) is similar to Harrill (1968).

Revised hydraulic gradient estimates differed from previous estimates. The revised hydraulic gradient between southern and northern Monitor Valleys was about 8 feet per mile (ft/mi) and was about $9 \mathrm{ft} / \mathrm{mi}$ between northern Monitor Valley and the western part of Kobeh Valley, whereas Rush and Everett (1964) estimated $20 \mathrm{ft} / \mathrm{mi}$ and $10 \mathrm{ft} / \mathrm{mi}$, respectively. The revised hydraulic gradient between Kobeh Valley and Diamond Valley through Devil's Gate was about $30 \mathrm{ft} / \mathrm{mi}$, whereas Harrill (1968) estimated about $10 \mathrm{ft} / \mathrm{mi}$. Hydraulic gradient differences probably resulted from the use of more detailed water-level data in this study and continued groundwater declines in southern Diamond Valley.

\section{Change in Groundwater Storage}

Groundwater withdrawal alters the steady state, or predevelopment, flow system because the source of pumped water is either from an increase in inflow, a decrease in outflow, a decrease in groundwater storage, or some combination of these three. In the DVFS, the source of most pumped groundwater is storage, with lesser amounts from the capture of $\mathrm{ET}_{\mathrm{gw}}$ (which includes reduced spring discharge). This was inferred because, in Diamond Valley and the DVFS, groundwater was withdrawn primarily outside the GDA or along the sparse edge of the GDA, and the leading edge of the cone of depression in southern Diamond Valley was coincident with the southern extent of the GDA. The change in groundwater storage must be evaluated to adequately describe the groundwater budget under recent, post-development conditions in the DVFS. For this study, recent conditions were represented by the annual average water budget for 2011-12. The volume of groundwater removed from storage was estimated using two independent methods.

The first method assumed that the decrease in groundwater storage was equivalent to the estimate of net pumping less the decrease in $\mathrm{ET}_{\mathrm{gw}}$, which was equivalent to the reduction in spring discharge. The second method, the water-level differencing approach, is based on changes in groundwater levels over time multiplied by the specific yield of the basinfill aquifers. Storage-change estimates using groundwater levels were made only in the southern part of Diamond Valley, because all other areas lacked sufficient historic waterlevel data and were assumed to be relatively steady. Storage changes were evaluated from 1950 to 2012 and from 2005 to 2012 using water-level contours from Harrill (1968), Tumbusch and Plume (2006), and those developed for this study (plate 1). Water-level contours from previous studies were digitized, and contours from the three separate studies were interpolated to create continuous water-level surfaces. The pre-development (1950) water-level surface in the southern part of Diamond Valley created from Harrill (1968) was 
subtracted from the post-development spring 2012 surface and multiplied by the estimated distribution of specific yield (Harrill, 1968). The resultant product represented the volume of groundwater removed from storage between 1950 and spring 2012. The change in groundwater storage from 2005 (Tumbusch and Plume, 2006) to 2012 was computed using the same procedure.

\section{Groundwater Budgets}

Pre-development (before 1950) and recent (2011-12) groundwater budgets were developed for each hydrographic area in the DVFS. A pre-development groundwater budget is representative of hydrologic conditions prior to notable groundwater withdrawals and when the groundwater system was in a state of dynamic equilibrium (Theis, 1940). Under pre-development conditions, the volume of inflow equaled the volume of outflow, and change in groundwater storage was assumed to be negligible. Early development in the DVFS consisted of diversion of natural streamflow or springs for direct irrigation of meadow grass and alfalfa or for storage in small reservoirs for later irrigation use (Rush and Everett, 1964; Harrill, 1968). Minor groundwater withdrawals probably began in the 1940s. Large groundwater withdrawals, mainly in the southern part of Diamond Valley, began in the early 1960s and steadily increased to a maximum by the mid1980s (fig. 21). For the purposes of this study, the pre-development groundwater budget represents annual groundwater conditions prior to 1950 . The recent, or "post-development," groundwater budget reflects groundwater conditions as an average annual for 2011-12.

Measured and precipitation-adjusted $\mathrm{ET}_{\mathrm{gw}}$ rates used to estimate basin-scale groundwater discharge were assumed representative of pre-development long-term rates in the study area. The site-based $\mathrm{ET}_{\mathrm{gw}}$ rates used to scale values to the basin level were measured in undisturbed areas representative of pre-development, steady-state conditions. Average annual precipitation during the $\mathrm{ET}_{\mathrm{gw}}$ measurement period reflected long-term rates and groundwater-levels within groundwaterdischarge areas changed minimally from pre-development conditions to the study period, indicating that $\mathrm{ET}$ and $\mathrm{ET}_{\mathrm{gw}}$ source water availability reflected long-term conditions. Although precipitation rates measured at ET sites in Kobeh Valley varied from 2011 to 2012, the average precipitation during 2011 and 2012 was generally similar to the long-term average for the area (fig. 3). Relative precipitation differences between basins, which were used to up-scale site-based $\mathrm{ET}_{\mathrm{gw}}$ rates, were based on long-term average annual-precipitation rates from PRISM. Seasonal fluctuations in groundwater-level were similar during 2011 and 2012 (fig. 13), indicating that the removal of groundwater by ET was similar each year.

The EVI image used to up-scale site-based estimates was modified to reflect pre-development conditions by identifying anthropogenically disturbed areas in the GDA and replacing EVI values in these areas with those from adjacent undisturbed areas. Changes in spring-discharge rates and vegetation cover (with the exception of Diamond Valley) were assumed to be minimal outside of these disturbed areas. In Diamond Valley, spring diversions pre-dating the 1960s and the decline in spring flow that began in the early 1990s likely affected areas beyond those delineated. The effect of declining spring flow on vegetation and estimated pre-development $\mathrm{ET}_{\mathrm{gw}}$ was compensated for by adding the change in annual spring discharge to EVI-based groundwater $\mathrm{ET}_{\mathrm{gw}}$ estimates.

\section{Pre-development}

Total pre-development groundwater outflow ranged from 200 acre-ft/yr for Stevens Basin to 35,000 acre-ft/yr for Diamond Valley (table 17). Pre-development ET $_{\mathrm{gw}}$ estimates ranged from 0 acre-ft/yr in Stevens Basin to 29,000 acre-ft/yr in Diamond Valley (table 17). Total pre-development outflow estimated for Diamond Valley comprised 29,000 acre-ft/yr of $\mathrm{ET}_{\mathrm{gw}}$, based on the distribution and density of post-development phreatophytes, and 6,000 acre-ft/yr of $\mathrm{ET}_{\mathrm{gw}}$, based on observed spring-flow loss since the mid-1960s. Estimated $\mathrm{ET}_{\mathrm{gw}}$ from shrubland ET unit accounted for about 70 percent or more of the total $\mathrm{ET}_{\mathrm{gw}}$ in each basin, except for northern Monitor Valley, where shrubland $\mathrm{ET}_{\mathrm{gw}}$ accounted for about 52 percent, and grassland $\mathrm{ET}_{\mathrm{gw}}$ accounted for the remainder (table 16). Playa occupied nearly 35 percent of the GDA in Diamond Valley and about 4 percent of the GDA in southern Monitor Valley, but $\mathrm{ET}_{\mathrm{gw}}$ from the playa accounted for only about 7 percent and less than 1 percent of total $\mathrm{ET}_{\mathrm{gw}}$ from these basins, respectively.

Groundwater ET estimates for the hydrographic areas were generally greater than the upper range of previous estimates, but were of similar magnitude to them (table 17; Eakin, 1962; Rush and Everett, 1964; Harrill, 1968; Heilweil and Brooks, 2011). The estimated mean-annual $\mathrm{ET}_{\mathrm{gw}}$ in the DVFS under pre-development conditions was about 70,000 acre-ft. No $\mathrm{ET}_{\mathrm{gw}}$ was estimated for Stevens Basin, owing to the great depth to groundwater (greater than $450 \mathrm{ft}$ ). Differences in basin-scale $\mathrm{ET}_{\mathrm{gw}}$ were attributable to differences in the ET unit areas and the $\mathrm{ET}_{\mathrm{gw}}$ rates applied. The mapped GDAs in Antelope and northern and southern Monitor Valleys were comparable to previous studies; however, in Diamond and Kobeh Valleys, delineated GDAs were 1.1 and 1.8 times larger, respectively, than were mapped in previous studies (table 15). Area differences could be due to the use of aerial and satellite imagery and GPS mapping techniques for determination of the GDA. Earlier mapping might have excluded some areas of lower density phreatophytes included in the recent boundary to avoid overestimating discharge when using a single mean rate in the GDA.

Area-weighted mean $\mathrm{ET}_{\mathrm{gw}}$ rates in acre-ft/acre for shrubland (0.30-0.40 acre-ft/acre across all basins) were similar to previous studies (0.2-0.4 acre-ft/acre), whereas the areaweighted rates for grassland (0.83-1.02 acre-ft/acre across all basins) were generally less than those from previous studies (1.2-3 acre-ft/acre; Eakin, 1962; Rush and Everett, 1964; 
Table 17. Estimated outflow components of the annual groundwater budget, in acre-feet, for pre-development and recent conditions (average annual 2011-12), Diamond Valley flow system, central Nevada.

[All values rounded to two significant figures. $<$, less than; - , no data]

\begin{tabular}{|c|c|c|c|c|c|c|c|c|c|}
\hline \multirow{2}{*}{ Hydrographic area } & \multicolumn{3}{|c|}{$\begin{array}{l}\text { Groundwater discharge by } \\
\text { evapotranspiration }\end{array}$} & \multicolumn{3}{|c|}{ Subsurface outflow to adjacent areas } & \multirow{2}{*}{$\begin{array}{c}\text { Net } \\
\text { groundwater } \\
\text { withdrawals } \\
\begin{array}{c}\text { Annual average } \\
(2011-12)^{4}\end{array}\end{array}$} & \multicolumn{2}{|c|}{ Total outflow } \\
\hline & $\begin{array}{c}\text { Previous } \\
\text { estimates }^{1}\end{array}$ & $\begin{array}{c}\text { Pre- } \\
\text { development }\end{array}$ & $\begin{array}{c}\text { Recent } \\
(2011-12)^{2}\end{array}$ & $\begin{array}{c}\text { Previous } \\
\text { estimates }^{3}\end{array}$ & $\begin{array}{c}\text { Pre- } \\
\text { development }\end{array}$ & $\begin{array}{c}\text { Recent } \\
\text { (2011-12) }\end{array}$ & & $\begin{array}{c}\text { Pre- } \\
\text { development }^{5}\end{array}$ & $\begin{array}{c}\text { Recent } \\
(2011-12)^{6}\end{array}$ \\
\hline Southern Monitor Valley & 9,200 & 11,000 & 11,000 & 2,000 & 1,400 & 1,400 & 550 & 12,000 & 13,000 \\
\hline Northern Monitor Valley & 2,000 & 2,900 & 2,900 & 6,000 & 3,400 & 3,400 & 0 & 6,300 & 6,300 \\
\hline Antelope Valley & 4,200 & 4,400 & 4,400 & Trace & $<800$ & $<800$ & 420 & 5,200 & 5,600 \\
\hline Kobeh Valley & 15,000 & 17,000 & 17,000 & 150 & 130 & 130 & 600 & 17,000 & 18,000 \\
\hline Stevens Basin & 0 & 0 & 0 & 200 & 200 & 200 & 0 & 200 & 200 \\
\hline Diamond Valley & $30,000^{7}$ & $35,000^{8}$ & 29,000 & 0 & 0 & 0 & 67,000 & 35,000 & 96,000 \\
\hline Diamond Valley flow system & - & 70,000 & 64,000 & - & 0 & 0 & 69,000 & 70,000 & 133,000 \\
\hline
\end{tabular}

${ }^{1}$ Rush and Everett (1964) for Southern and Northern Monitor Valleys, Antelope Valley, Kobeh Valley, and Stevens Basin, Harrill (1968) Diamond Valley. Heilweil and Brooks (2011) discharge values represent an average of previous estimates and are not included.

${ }^{2}$ Represents long-term average annual groundwater ET, excluding irrigated lands.

${ }^{3}$ Rush and Everett (1964) and Harrill (1968).

${ }^{4}$ Estimated from the product of annual average irrigated acreage and net irrigation water requirement (2.7 acre-feet/acre; Rick Felling, NDWR, July 24, 2014). Annual average irrigated acreage for Diamond Valley and Kobeh Valley (2011-12) obtained from Nevada Division of Water Resources (NDWR) (http://water.nv.gov/mapping/inventories/cropinv.cfm, accessed March 3, 2014). Southern Monitor Valley and Antelope Valley annual average acreage (2010) estimated from summer-time satellite imagery and remote-sensing techniques.

${ }^{5}$ Pre-development total outflow was calculated as the sum of pre-developmet groundwater discharge by evapotranspiration and pre-development subsurface outflow to adjacent areas.

${ }^{6}$ Annual average (2011-12) total outflow was calculated as the sum of average annual (2011-12) groundwater discharge by evapotranspiration, average annual (2011-12) subsurface outflow to adjacent areas, and average annual (2011-12) net groundwater withdrawals.

${ }^{7}$ Eakin (1962) estimated discharge in Diamond Valley for the native vegetation, meadow, and pasture grasses, and excluded a playa discharge estimate.

${ }^{8}$ Estimate includes 29,000 acre-feet per year groundwater evapotranspiration (ETg) and 6,000 acre-feet per year representing observed spring-flow declines since pre-development time.

Harrill, 1968; table 15). Lower estimates of $\mathrm{ET}_{\mathrm{gw}}$ in grassland areas were likely attributable to its measured rates at site 4 , which were slightly less than grassland $\mathrm{ET}_{\mathrm{gw}}$ rates from other recent studies in northeastern Nevada (see the "SiteLevel Groundwater Evapotranspiration" section). Although area-weighted mean $\mathrm{ET}_{\mathrm{gw}}$ rates were comparable among shrubland ET units overall, estimated $\mathrm{ET}_{\mathrm{gw}}$ rates in this study for Antelope and northern Monitor Valleys ( 0.40 and $0.37 \mathrm{ft} /$ $\mathrm{yr}$, respectively) were the highest among the five discharging basins, whereas rates applied in Rush and Everett (1964; 0.2 $\mathrm{ft} / \mathrm{yr}$ ) for these two basins were the lowest of the reconnaissance estimates among the five basins. These differences could be attributable to the low $\mathrm{ET}_{\mathrm{gw}}$ rates applied in the reconnaissance studies (and determined in distant basins) and to uncertainties in the recent $\mathrm{ET}_{\mathrm{gw}}$ estimates (table 16; see the "Groundwater Evapotranspiration Uncertainty" section).

The estimated mean-annual subsurface outflow to adjacent basins, where estimated, ranged from 0 acre-ft from Diamond Valley to 3,400 acre-ft from northern Monitor Valley to the western part of Kobeh Valley (table 17). Revised estimates of subsurface outflow for southern and northern Monitor Valley were 30 and 43 percent less, respectively, than previous estimates (600 and 2,600 acre-ft, respectively) as a result of the lower gradient estimated between southern and northern Monitor Valley and the shorter flow section delineated between northern Monitor and Kobeh Valleys in this study. A maximum mean-annual subsurface flow estimate of 800 acre-ft from Antelope to Kobeh Valley was determined on the basis of surface geology and recent groundwater data. Additional field mapping and aquifer testing is required to make a better estimate of subsurface outflow from Antelope Valley. No re-evaluation of subsurface outflow from Stevens Basin was made. The value of 200 acre-ft reported by Rush and Everett (1964) was used in the calculation for total outflow in this study. The hydrographic area receiving this outflow is unknown.

Groundwater recharge from precipitation was the greatest inflow component and was assumed to be minimally affected by groundwater withdrawals (table 18). For this study, estimates of recharge from precipitation were based on a waterbalance relation where recharge from precipitation is equivalent to the sum of $\mathrm{ET}_{\mathrm{gw}}$ and net subsurface outflow (subsurface outflow minus subsurface inflow). Excluding Diamond Valley, recharge estimates from the water-balance method in this study were within 20 percent of Maxey-Eakin method recharge estimates. Values for southern and northern Monitor Valleys were less than Maxey-Eakin method estimates, whereas values for Antelope and Kobeh Valleys were greater (table 18; Eakin, 1962; Rush and Everett, 1964; Harrill, 1968). Recharge estimates from the BCM (Flint and others, 2004; Heilweil and Brooks, 2011) were generally greater than Maxey-Eakin estimates for all basins. In this study, there was insufficient data to differentiate groundwater recharge from subsurface inflow in Diamond Valley and Diamond Valley 
Table 18. Estimated inflow components for annual groundwater budget, in acre-feet, representing pre-development and recent conditions (average annual 2011-12), Diamond Valley flow system, central Nevada.

[All values rounded to two significant figures. BCM, Basin Characterization Model; - , no data]

\begin{tabular}{|c|c|c|c|c|c|c|}
\hline \multirow[b]{2}{*}{ Hydrographic area } & \multicolumn{3}{|c|}{ Groundwater recharge from precipitation } & \multicolumn{2}{|c|}{ Subsurface inflow from adjacent areas } & \multirow{2}{*}{$\begin{array}{c}\text { Total inflow } \\
\text { Pre-development } \\
\text { and recent } \\
(2011-12)^{4}\end{array}$} \\
\hline & Maxey-Eakin Method ${ }^{1}$ & $\mathrm{BCM}^{2}$ & $\begin{array}{l}\text { Pre-development } \\
\text { and recent } \\
(2011-12)^{3}\end{array}$ & $\begin{array}{c}\text { Previous } \\
\text { estimates }^{1}\end{array}$ & $\begin{array}{l}\text { Pre-development } \\
\text { and recent } \\
(2011-12)\end{array}$ & \\
\hline Southern Monitor Valley & 15,000 & $16,000-27,000$ & 12,000 & 0 & 0 & 12,000 \\
\hline Northern Monitor Valley & 6,300 & $10,000-34,000$ & 4,900 & 2,000 & 1,400 & 6,300 \\
\hline Antelope Valley & 4,100 & $5,000-5,900$ & 5,200 & Trace & 0 & 5,200 \\
\hline Kobeh Valley & 11,000 & $8,400-19,000$ & 13,000 & 6,000 & 4,200 & 17,000 \\
\hline Stevens Basin & 200 & 1,400 & 200 & 0 & 0 & 200 \\
\hline Diamond Valley & $16,000-21,000$ & $15,000-23,000$ & 5 & 69,200 & 5 & 35,000 \\
\hline Diamond Valley flow system & - & - & 5 & - & 5 & 70,000 \\
\hline
\end{tabular}

${ }^{1}$ Rush and Everett (1964) for Southern and Northern Monitor Valleys, Kobeh Valley, Antelope Valley, and Stevens Basin; Eakin (1962) for Diamond Valley; Harrill (1968) for Diamond Valley.

${ }^{2}$ Flint and others (2004), Heilweil and Brooks (2010).

${ }^{3}$ Based on the sum of groundwater evapotranspiration (ET) and net subsurface flow and assumes hydrologic flow system is in dynamic equilibrium (inflow equals outflow). No groundwater ET takes place in Stevens Basin, the Maxey-Eakin estimate for groundwater recharge of Rush and Everett (1964) was used.

${ }^{4}$ Pre-development/average annual total inflow was calculated as the sum of pre-development/average annual groundwater recharge from precipitation and pre-development/average annual subsurface inflow from adjacent areas.

${ }^{5}$ Insufficient data to differentiate groundwater recharge from subsurface inflow.

${ }^{6}$ Includes 150 acre-feet inflow from eastern Kobeh Valley to southern Diamond Valley through Devil's gate (current estimate is 130 acre-feet) and 9,000 acre-feet from Garden Valley (Harrill, 1968). Subsurface flow from Garden Valley was not re-evaluated or included in current study.

recharge estimates, based on the water-balance method, were greater than the upper range of Maxey-Eakin and BCM estimates (by 19 and 9 percent, respectively). Groundwater recharge in Stevens Basin was not estimated in this study, therefore the Maxey-Eakin method based estimate of 200 acre$\mathrm{ft} / \mathrm{yr}$ from Rush and Everett (1964) was used (table 18). Total groundwater inflow from precipitation and subsurface inflow from adjacent basins in the DVFS is about 70,000 acre-ft/yr.

The estimated mean-annual subsurface inflow from adjacent basins ranged from 0 acre-ft/yr in southern Monitor Valley, Antelope Valley, and Stevens Basin to 1,400 acre-ft/yr in northern Monitor Valley and 4,200 acre-ft/yr in Kobeh Valley (table 18). Harrill's (1968) estimate of subsurface inflow to Diamond Valley was about 9,200 acre-ft/yr, of which 9,000 acre-ft/yr was assumed to originate from Garden Valley. This estimate was based on an imbalance in the estimated water budget for Garden Valley, where recharge from precipitation was about 9,000 acre-ft/yr greater than estimated discharge (Harrill, 1968). The potential for subsurface flow from Garden Valley was not re-evaluated during this study; consequently, there were insufficient data to differentiate between groundwater recharge and subsurface inflow to Diamond Valley.

\section{Recent (2011-12)}

The 2011-12 groundwater budget for each hydrographic area incorporated estimates of $\mathrm{ET}_{\mathrm{gw}}$, recharge from precipitation, interbasin flow, spring-flow losses, and net groundwater withdrawals. Outflow estimates were greater than inflow for most areas, and the differences were generally accounted for by a decrease in groundwater-storage (table 19) due to groundwater withdrawal. Imbalances computed for all areas, except
Diamond Valley, were within 10 percent of inflow and outflow estimates.

Diamond Valley had the greatest imbalance between groundwater inflow and outflow, about 61,000 acre-ft (table 19), because of groundwater withdrawals for irrigation in the southern part of the valley and the loss of an estimated $6,000 \mathrm{acre}-\mathrm{ft} / \mathrm{yr}$ of spring flow along the margins of the playa in the northern part of the valley. Estimated annual net groundwater withdrawal was about 65,000 acre-ft in the southern part and about 1,900 acre-ft in the northern part of Diamond Valley. Water levels have shown large declines throughout a large portion of the southern part of Diamond Valley as groundwater has been removed from storage in the basin-fill aquifer (plate 1).

Using the water-level differencing approach, the average annual volume of groundwater removed from storage during the period 2005 to 2011 was estimated to be about 20,000-33,000 acre-ft in the southern part of Diamond Valley or about 33 to 54 percent of the calculated imbalance between inflow and outflow. Total storage loss based on water-level declines during the 7 water years was on the order of 140,000-231,000 acre-ft compared to about 412,000 acre-ft of storage loss estimated from net groundwater withdrawals and reduction in $\mathrm{ET}_{\mathrm{gw}}$ during the same period. Storage-loss estimates based on net groundwater withdrawals were used in the budget calculations because the water-level differencing approach only was applicable in Diamond Valley, and the specific yield distribution of basin-fill deposits in Diamond Valley was uncertain. The average annual (2011-12) decrease in storage in Diamond Valley was about 61,000 acre-ft/yr (table 19) based on net groundwater withdrawals and the reduction in $\mathrm{ET}_{\mathrm{gw}}$. 
Table 19. Average annual groundwater budget, in acre-feet, representing current (2011-12) conditions, Diamond Valley flow system, central Nevada.

[All values rounded to two significant figures. Inflow values are from the Total inflow column in table 18. Outflow and Storage change values are from the Total outflow and Net groundwater withdrawals columns in table 17, respectively. BCM, Basin Characterization Model]

\begin{tabular}{lrrrr}
\hline \multicolumn{1}{c}{ Hydrographic area } & Inflow & Outflow & Storage change & Imbalance $^{\mathbf{1}}$ \\
\hline Southern Monitor Valley & 12,000 & 13,000 & -550 & -450 \\
\hline Northern Monitor Valley & 6,300 & 6,300 & 0 & 0 \\
Antelope Valley & 5,200 & 5,600 & -420 & 20 \\
\hline Kobeh Valley & 17,000 & 18,000 & -600 & -400 \\
Stevens Basin & 200 & 200 & 0 & 0 \\
\hline Diamond Valley & 35,000 & 96,000 & $2-61,000$ & 0 \\
\hline Diamond Valley flow system & 70,000 & 133,000 & $2-63,000$ & 0 \\
\hline
\end{tabular}

${ }^{1}$ Imbalance is equal to inflow minus outflow minus storage change.

${ }^{2}$ Reduction in spring discharge in Diamond Valley was estimated to be 6,000 acre-feet per year.

Groundwater is the source of nearly all the water supply in Diamond Valley, and it is derived from the depletion of groundwater storage; the capture of $\mathrm{ET}_{\mathrm{gw}}$ (which includes reduction in spring discharge); and, to a lesser extent, recycled irrigation water. Available groundwater supply typically is limited to the amount of $\mathrm{ET}_{\mathrm{gw}}$ that can be captured by pumping. Because agricultural development in the southern part of Diamond Valley was distant from the GDA (plate 1), most groundwater removed from the southern part of the valley came from storage. Whether the estimated 6,000 acre-ft/yr of spring-flow loss since pre-development in the northern part of Diamond Valley is entirely related to groundwater withdrawals or, is in part related to a decrease in precipitation is unknown. If the combination of net pumpage and $\mathrm{ET}_{\mathrm{gw}}$ continues to exceed pre-development $\mathrm{ET}_{\mathrm{gw}}$, water levels are likely to decline indefinitely, precluding establishment of a new equilibrium.

The overall groundwater budget for the DVFS under recent (2011-12) conditions was not in balance. Only if the volume of storage change, assumed to equal net groundwater withdrawals, was included, could the budget be considered in balance. Total annual inflow to the DVFS was about 70,000 acre-ft/yr, whereas outflow was nearly twice that $(133,000 \mathrm{acre}-\mathrm{ft} / \mathrm{yr})$, resulting in an average imbalance between inflow and outflow of about 63,000 acre-ft/yr during 2011-12 (table 19). The calculated imbalance was only about 9 percent less than the estimated storage change and reflected the uncertainty inherent in estimated budget components.

\section{Limitations of Methodology}

The accuracy of the groundwater budgets presented here is limited by the accuracy of the estimated inflow and outflow components. The largest independently derived water-budget components included groundwater discharge by ET, net groundwater withdrawals, and storage loss in Diamond Valley. Subsurface-flow estimates represented smaller, but noteworthy, components, especially in Diamond Valley.
Annual $\mathrm{ET}_{\mathrm{gw}}$ documented in this report has probable uncertainties averaging 16 percent for site-based estimates and more than 10 percent for the entire DVFS. Annual site-based ET estimates were considered to be of good quality, within the limits of the assumptions, because accepted data processing and correction methods were applied. The mean energybalance ratio calculated for all sites and water years $(0.9)$ was noticeably greater than the mean for other ET studies. The probable uncertainty in basin-scale estimates ranged from 13 percent for northern Monitor Valley to 23 percent for Diamond Valley. In Kobeh Valley, the probable uncertainty was 16 percent, and it incorporated EVI scene variability and site-based estimate uncertainties used to scale estimates to the basin level. In addition to uncertainties evaluated in Kobeh Valley, probable uncertainties in southern and northern Monitor, Antelope, and Diamond Valleys incorporated an additional 10 percent uncertainty to account for applying the rates measured in Kobeh Valley. The accuracy of site-based $\mathrm{ET}_{\mathrm{gw}}$ estimates was limited by site-based $\mathrm{ET}_{\mathrm{gw}}$ measurements, a lack of $\mathrm{ET}_{\mathrm{gw}}$ measurements in the DVFS basins other than Kobeh Valley, and any potential errors in differentiating ET units and assigning $\mathrm{ET}_{\mathrm{gw}}$ rates. Site-based $\mathrm{ET}_{\mathrm{gw}}$ was limited by the accuracy of the eddy-covariance method to estimate ET, the limited spatial extent of ET measurements, and the period during which ET and precipitation were measured.

The accuracy of basin-scale $\mathrm{ET}_{\mathrm{gw}}$ estimates was limited by the following assumptions: (1) $\mathrm{ET}_{\mathrm{gw}}$ was restricted to the GDA; (2) $\mathrm{ET}_{\mathrm{gw}}$ from vegetated ET units was adequately characterized by linear relations with vegetation indices; (3) $\mathrm{ET}_{\mathrm{gw}}$ rates from the playa ET unit in the DVFS were equivalent to playa $\mathrm{ET}_{\mathrm{gw}}$ rates in Dixie Valley, Nev.; (4) differences in $\mathrm{ET}_{\mathrm{gw}}$ among basins were primarily driven by vegetation density and precipitation magnitudes, and soil characteristics, depth to water, surface water, and effects related to confined or unconfined aquifers were negligible by comparison; (5) precipitation-adjusted $\mathrm{ET}_{\mathrm{gw}}$ estimates from Kobeh Valley were comparable to unmeasured rates in other DVFS basins, and relative differences in 30-year average annual PRISM precipitation model data for other DVFS basins were accurate; 
and (6) basin-scale $\mathrm{ET}_{\mathrm{gw}}$ estimates were representative of predevelopment conditions.

The accuracy of $\mathrm{ET}_{\mathrm{gw}}$ estimates can be improved and uncertainty reduced by establishing additional ET and precipitation sites in the GDA of each discharging basin and by measuring for longer periods than in this study. As was demonstrated by Moreo and others (2007), small changes in precipitation can affect $\mathrm{ET}_{\mathrm{gw}}$ rates in a basin. Similarly, application of $\mathrm{ET}_{\mathrm{gw}}$-vegetation index relations from measured to unmeasured basins can lead to errors in basin-scale discharge estimates. Establishing ET sites in each basin would decrease the amount of interpolation and extrapolation and provide a dataset that allows the effects of differences in precipitation, soil texture, background reflectance, depth to groundwater, and phreatophyte distributions to be evaluated.

The accuracy of groundwater withdrawals, storage loss, and subsurface-flow estimates were limited by the simplifying assumptions used to compute these components. Limiting assumptions for groundwater withdrawal estimates were (1) a net groundwater-pumping rate of 2.7 acre-ft/acre accurately represented the volume of water used by crops and pastureland, and (2) the irrigated acreage reported to the State of Nevada was accurate. Estimates of groundwater-irrigated acreage in Diamond Valley and other valleys made from remotely sensed imagery produced results similar to values reported by the State; therefore these estimates were considered relatively accurate. The assumption that storage loss was equivalent to groundwater withdrawals was considered adequate because, in Diamond Valley and the DVFS at large, most groundwater was withdrawn outside the GDA or along the sparse edge of the GDA, and the leading edge of the cone of depression in southern Diamond Valley was coincident with the southern extent of the GDA.

The accuracy of subsurface-flow estimates was limited by the hydraulic variables used, such as flow sections, hydraulic gradients, and transmissivity. Subsurface-flow estimates could be improved by having additional wells between basins to more accurately measure hydraulic gradients and by using transmissivity estimates derived from aquifer tests rather than specific-capacity data, as were used by others and applied in this study.

\section{Summary}

The Diamond Valley flow system (DVFS), as defined by Harrill and others (1983), consists of six hydrographic areas in central Nevada that are hydrologically connected. Concerns relating to continued water-resources development in the DVFS resulted in a phased hydrologic investigation that began in 2005. The culmination of the phased approach, presented in this report, was designed to increase understanding of the groundwater resources in the DVFS by characterizing the groundwater quality and developing groundwater budgets representing pre-development (pre-1950) and recent conditions (average annual for 2011-12).

The large playa in the north part of Diamond Valley was the terminus of the groundwater-flow system before large scale groundwater withdrawals began in the south part of Diamond Valley. Sometime around the late 1960s, a groundwater divide developed between the area of natural discharge in the north part of Diamond Valley and the area of groundwater development in the south part. The estimated position of the groundwater divide appears to have migrated northward since 2005. This migration indicates that the cone of depression caused by groundwater pumping in the south is expanding radially, has not reached equilibrium, and, eventually, can lead to southward movement of poor-quality groundwater. In general, water-level altitudes and groundwater-flow directions have not changed since 2005 in the other hydrographic areas that make up the DVFS.

The majority of groundwater samples from Diamond, Antelope, northern Little Smoky, and southern and northern Monitor Valleys, and about half the samples from Kobeh Valley, were a calcium-bicarbonate water type. Groundwater samples throughout southern Kobeh Valley, central Diamond Valley, and southern Monitor Valley were a sodium-bicarbonate water type. As groundwater moved from the basin periphery in Diamond Valley from the south to the north, the cation chemistry changed from predominately a calcium-magnesium to a sodium type. Sulfate water types with various cation proportions were found in the northern part of southern Monitor Valley, the western part of Kobeh Valley, and west-central Diamond Valley. Groundwater quality in the DVFS generally was within acceptable drinking-water standards. Of the 100 well and spring sites sampled, only 10 exceed the secondary maximum contaminant level (MCL) for total dissolved solids (TDS) of 500 milligrams per liter.

Stable-isotope signatures of oxygen-18 and deuterium in groundwater and precipitation indicated recharge in the DVFS was relatively recent and was derived from cool-season precipitation. Precipitation samples collected at the four Kobeh Valley evapotranspiration (ET) sites exhibited a strong seasonal pattern with more evaporative enrichment in samples collected during warmer months (July, August, and September) compared to samples collected in cooler months (October, November, and February). Groundwater sampled from 34 well and spring sites was slightly enriched in oxygen-18 relative to the global meteoric water line. This enrichment could reflect groundwater interaction with warmer water along deep flow paths. 
Groundwater budgets summarize groundwater inflows, outflows, and changes in groundwater storage. Groundwater conditions in the DVFS prior to about 1950 were considered to be in dynamic equilibrium and were assumed to be representative of pre-development conditions, where groundwater inflow was approximately equal to groundwater outflow, and changes in groundwater storage were negligible. Once pumping began, the equilibrium between inflow and outflow was disrupted, and the source of the pumped groundwater needed to be accounted for in a post-development budget. In the DVFS, most pumped water was accounted for by a decrease in groundwater storage and by the capture of natural groundwater discharge, $\mathrm{ET}_{\mathrm{gw}}$.

Pre-development (pre-1950) and recent (2011-12) groundwater budgets were developed for each hydrographic area in the DVFS. The pre-development budget included natural groundwater discharge by ET, whereas the recent budget (2011-12) included discharge by ET plus groundwater withdrawals and related decreases in groundwater storage change and declines in spring flow. Components of groundwater outflow included ET by phreatophytes and bare soil, and evaporation from playas (collectively called groundwater evapotranspiration; $\mathrm{ET}_{\mathrm{gw}}$ ), net groundwater withdrawals, and subsurface outflow. Components of groundwater inflow included recharge from mountain block (in place) precipitation, infiltration of streamflow and runoff, and subsurface inflow from adjacent basins. Subsurface (interbasin) flow between basins represented small, but important, components of individual hydrographic-area budgets.

Site estimates of groundwater discharge in Kobeh Valley and net irrigation-water requirements for alfalfa in Diamond Valley were combined with satellite imagery to scale groundwater discharge from the site to the basin level. Annual site-scale $\mathrm{ET}_{\mathrm{gw}}$ estimates increased with increasing vegetation density from 0.15 feet per year (ft/yr) at site 1 to $1.13 \mathrm{ft} / \mathrm{yr}$ at site 4. A vegetation index- $\mathrm{ET}_{\mathrm{gw}}$ relation was used to partition the groundwater discharge area (GDA) into shrubland and grassland ET units and to calculate basin-scale $\mathrm{ET}_{\mathrm{gw}}$ for each of those units, whereas playa ET units were delineated with satellite and aerial imagery, and discharge rates from a recent nearby study were used. Recent average annual basin-scale $\mathrm{ET}_{\mathrm{gw}}$ estimates ranged from 0 in Stevens Basin to 29,000 acre-ft/yr in Diamond Valley. An additional 6,000 acre-ft/yr of spring-flow loss since pre-development time was included in the total outflow from Diamond Valley (35,000 acre-ft/yr). This 6,000 acre-ft/yr most likely represented a maximum spring-flow loss, because seasonal variability in spring flow was not generally known. The estimated groundwater discharge from the shrubland ET unit accounted for 80 percent or more of total discharge for each valley, except for northern Monitor Valley, where shrubland accounted for only 57 percent of total discharge, and grassland accounted for the remainder. Playas covered about 35 percent of Diamond Valley and 4 percent of southern Monitor Valley, but the playa ET unit accounted for only about 6 percent and 1 percent of discharge in those valleys, respectively.
Groundwater withdrawals in the DVFS mostly supported agriculture in the southern part of Diamond Valley. Estimates of net groundwater withdrawals were determined by assuming 10 percent of the gross pumpage returns to the groundwater system. Net groundwater withdrawals were determined by the product of irrigated acres and 2.7 acre-ft/acre and were considered to be minimum values. The average annual estimates of groundwater pumping (2011-12) ranged from 0 in northern Monitor Valley and Stevens Basin to 67,000 acre-ft/yr in Diamond Valley. Estimates of net groundwater pumpage were assumed to be equivalent to the change in groundwater storage minus the decrease in $\mathrm{ET}_{\mathrm{gw}}$.

In the DVFS, recharge to the groundwater system from precipitation was minimally affected by groundwater development and was assumed to be relatively constant with time. Under steady-state conditions and limited groundwater development, inflow derived from precipitation and subsurface inflow equals outflow derived from groundwater ET and subsurface outflow. For this study, estimates of recharge from precipitation were based on a water-balance relation where recharge was equivalent to the sum of $\mathrm{ET}_{\mathrm{gw}}$ and net subsurface outflow. The average annual groundwater inflow ranged from 200 acre-ft/yr in Stevens Basin to 35,000 acre-ft/yr in Diamond Valley.

Subsurface flow through the basin-fill aquifer between basins was re-evaluated in this study using transmissivity estimates made previously, groundwater flow sections derived from remotely sensed imagery, and hydraulic gradients determined from 2012 water-level data. Subsurface outflow to adjacent basins in the DVFS ranged from 0 acre-ft from Diamond Valley to 3,400 acre-ft from northern Monitor Valley to the western part of Kobeh Valley. Recent subsurface-inflow estimates to adjacent basins in the DVFS ranged from 0 in southern Monitor Valley, Antelope Valley, and Stevens Basin to $4,200 \mathrm{acre}-\mathrm{ft} / \mathrm{yr}$ to Kobeh Valley. Not enough information was available to estimate subsurface inflow to Diamond Valley.

Under pre-development conditions, inflows equaled outflows, and individual hydrographic areas were in balance. Inflow and outflow values ranged from $200 \mathrm{acre}-\mathrm{ft} / \mathrm{yr}$ for Stevens Basin to 35,000 acre-ft/yr for Diamond Valley. The DVFS was also in balance at about 70,000 acre-ft/yr. Under recent conditions, estimates of outflow were greater than inflow for most areas; however, the imbalances were generally accounted for by estimates of net groundwater pumpage, which was assumed to be equivalent to groundwater-storage change. Imbalances computed for all areas, except Diamond Valley, generally were less than 10 percent of inflow and outflow estimates.

The overall groundwater budget for the DVFS under recent (2011-12) conditions was generally in balance, if storage change was considered. Total annual inflow to the DVFS was about 70,000 acre-ft/yr, whereas outflow was nearly twice that, resulting in an imbalance of about 63,000 acre-ft/yr during 2011-12. The calculated imbalance was about 9 percent less than the estimated storage change and was a result of the uncertainty in estimated budget components. 


\section{References Cited}

Allander, K.K, Smith, J.L, and Johnson, M.J., 2009, Evapotranspiration from the Lower Walker River Basin, West-Central Nevada, Water Years 2005-07: U.S. Geological Survey Scientific Investigations Report 2009-5079, 63 p., http:// pubs.usgs.gov/sir/2009/5079/.

Arakel, A.V., Jacobson, G., and Lyons, W.B., 1990, Sedimentwater interaction as a control on geochemical evolution of playa lake systems in the Australian arid interior: Hydrobiologia, v. 197, p. 1-12.

Berger, D.L., Johnson, M.J., Tumbush, M.L., and Mackay, J., 2001, Estimates of evapotranspiration from the Ruby Lake National Wildlife Refuge Area, Ruby Valley, northeastern Nevada, May 1999-October 2000: U.S. Geological Survey Water-Resources Investigations Report 01-4234, 38 p., http://pubs.usgs.gov/wri/wri014234/.

Bowen, I.S., 1926, The ratio of heat losses by conduction and by evaporation from any water surface: Physical Review, v. 27, p. $779-787$.

Brooks, L.E., Masbruch, M.D., Sweetkind, D.S., and Buto, S.G., 2014, Steady-state numerical groundwater flow model of the Great Basin carbonate and alluvial aquifer system: U.S. Geological Survey Scientific Investigations Report 2014-5213, 124 p.

Campbell, G.S., and Norman, J.M., 1998, An Introduction to Environmental Biophysics (2nd ed.): New York, SpringerVerlag, 286 p.

Campbell Scientific, Inc., 2010, Instruction manual for NRLITE Net Radiometer, revision 5/10, accessed May 6, 2015, at https://s.campbellsci.com/documents/us/manuals/nr-lite.pdf.

Clark, I., and Fritz, P., 1997, Environmental isotopes in hydrogeology: Boca Raton, Fla., CRC Press, 328 p.

Craig, H., 1961, Isotopic variations in meteoric waters: Science, v. 133, p. 1,702-1,703.

Drever, J.I., 1988, The geochemistry of nature water (second ed.): Englewood Cliffs, New Jersey, , Prentice Hall, Inc., $437 \mathrm{p}$.

Eakin, T.E., 1962, Ground-water appraisal of Diamond Valley, Eureka and Elko Counties, Nevada: Nevada Department of Conservation and Natural Resources, Ground-Water Resources Reconnaissance Series Report 6, 60 p.

Eakin, T.E., Maxey, G.B., Robinson, T.W., Fredericks, J.C., and Leltz, O.J., 1951, Contributions to the hydrology of eastern Nevada: Nevada State Engineer, Water Resources Bulletin 12, $171 \mathrm{p}$.
Flint, A.L., Flint, L.E., Hevesi, J.A., and Blainey, J.M., 2004, Fundamental concepts of recharge in the Desert Southwest: a regional modeling perspective, in Hogan, J.F., Phillips, F.M., and Scanlon, B.R., eds., Groundwater recharge in a desert environment: The Southwestern United States: American Geophysical Union, Water Science and Applications Series, v. 9, p. $159-184$

Flint, A.L., and Flint, L.E., 2007, Application of the basin characterization model to estimate in-place recharge and runoff potential in the Basin and Range carbonate-rock aquifer system, White Pine County, Nevada, and adjacent areas in Nevada and Utah: U.S. Geological Survey Scientific Investigations Report 2007-5099, 20 p., http://pubs.usgs.gov/sir/2007/5099/.

Foken, T., Leuning, R., Oncley, S.R., Mauder, M., and Aubinet, M., 2012, Corrections and data quality control, in Aubinet, M., and others, eds., Eddy covariance - A practical guide to measurement and data analysis: Springer Atmospheric Sciences, $438 \mathrm{p}$.

Friedman, Irving, 1953, Deuterium content of natural waters and other substances: Geochimica et. Cosmochimica Acta, v. 4, p.89-103.

Fuchs, M., 1987, Heat flux, in Klute, A., ed., Methods of soil analysis, part 1: Physical and mineralogical methods, Agronomy, a series of monographs: Madison, Wisc., American Society of Agronomy and Soil Science Society of America, 957-968.

Garcia, C.A., Huntington, J.M., Buto, S.G., Moreo, M.T., Smith, J.L., and Andraski, B.J., 2014, Groundwater discharge by evapotranspiration, Dixie Valley, West-Central Nevada, March 2009-September 2011: U.S. Geological Survey Professional Paper 1805, 90 p., http://pubs.usgs.gov/pp/1805.

Glenn, E.P., Huete, A.R., Nagler, P.L., Nelson, S.G., 2008, Relationship between remotely-sensed vegetation indices, canopy attributes and plant physiological processes: what vegetation indices can and cannot tell us about the landscape: Sensors, v. 8, no. 4, p. 2136-2160.

Hardman, George, 1936, Nevada precipitation and acreages of land by rainfall zones: University of Nevada, Reno, Agricultural Experiment Station Report, 10 p.

Hardman, George, and Mason, H.G., 1949, Irrigated lands in Nevada: University of Nevada, Reno, Agricultural Experiment Station Bulletin 183, 57 p.

Harrill, J.R., 1968, Hydrologic response to irrigation pumping in Diamond Valley, Eureka, and Elko Counties, Nevada, 1950-65: State of Nevada Department of Conservation and Natural Resources Water Resources Bulletin 35, 85 p. 
Harrill, J.R, Welch A.H., Prudic, D.E., Thomas, J.M., Carman, R.L., Plume, R.W., Gates, J.S., and Mason, J.L., 1983, Aquifer systems in the Great Basin region of Nevada, Utah, and adjacent states: A study plan: U.S. Geological Survey Open-File Report 82-445, 49 p., http://pubs.er.usgs.gov/ publication/ofr 82445 .

Harrill, J.R., Gates, J.S., and Thomas, J.M., 1988, Major groundwater flow systems in the Great Basin region of Nevada, Utah, and adjacent states: U.S. Geological Survey Hydrologic Investigations Atlas HA-694-C, scale $1: 1,000,000,2$ sheets.

Heilweil, V.M. and Brooks, L.E., ed., 2011, Conceptual model of the Great Basin carbonate and alluvial aquifer system: U.S. Geological Survey Scientific Investigations Report 2010-5193, p. 73-125, http://pubs.usgs.gov/sir/2010/5193/.

Hem, J. D., 1985, Study and interpretation of the chemical characteristics of natural water, U.S. Geological Survey Water-Supply Paper 2254, 264 p., http://pubs.usgs.gov/wsp/ wsp2254/.

Houghton, J.G., Sakamoto, C.M., and Gifford, R.O., 1975, Nevada's weather and climate: Nevada Bureau of Mines and Geology Special Publication 2, 78 p.

Huete, A.R., Justice, C., and van Leeuwen, W., 1999, MODIS Vegetation Index (MOD 13), Version 3, Algorithm theoretical basis document, http://modis.gsfc.nasa.gov/data/atbd/ atbd_mod13.pdf.

Huntington, J.L., and Allen, R.G., 2010, Evapotranspiration and net irrigation water requirements for Nevada: Nevada Division of Water Resources, 260 p., http://water.nv.gov/mapping/et/Docs/Evapotranspiration_ and_Net_Irrigation_Requirements_for_Nevada_Compiled. $p d f$.

Huntington, J.M., Garcia, C.A., and Rosen, M.R., 2014, Hydrogeologic framework and occurrence, movement, and chemical characterization of groundwater in Dixie Valley, west-central Nevada: U.S. Geological Survey Scientific Investigations Report 2014-5152, 60 p., http://dx.doi.org/10.3133/sir20145152.

Knochenmus, L.A., Berger, D.L., Moreo, M.T., and Smith, J.L., 2011, Data network, collection, and analysis in the Diamond Valley flow system, central Nevada: U.S. Geological Survey Open-File Report 2011-1089, 24 p., http://pubs.usgs.gov/of/2011/1089/.

Laczniak, R.J., DeMeo, G.A., Reiner, S.R., Smith, J.L., and Nylund, W.E., 1999, Estimates of ground-water discharge as determined from measurements of evapotranspiration, Ash Meadows area, Nye County, Nevada: U.S. Geological Survey Water-Resources Investigations Report 99-4079, 70 p., http://pubs.usgs.gov/wri/wri994079/text/contents.htm.
Laczniak, R.J., Smith, J.L., Elliot, P.E., DeMeo, G.A., and Chatigny, M.A., 2001, Ground-water discharge determined from estimates of evapotranspiration, Death Valley regional flow system, Nevada and California: U.S. Geological Survey Water-Resources Investigations Report 01-4195, 51 p., http://pubs.usgs.gov/wri/wri014195/text/04_introduction. htm.

Laczniak, R.J., Flint, A.L., Moreo, M.T., Knochenmus, L.A., Lundmark, K.W., Pohll, G., Carroll, R.W.H., Smith, J.L., Welborn, T.L., Heilweil, V.M., Pavelko, M.T., Hershey, R.L., Thomas, J.M., Earman, S., and Lyles, B.F., 2008, Groundwater budgets, section in Welch, A.H., Bright, D.J., and Knochenmus, L.A., Water resources of the Basin and Range Carbonate-Rock Aquifer system, White Pine County, Nevada, and adjacent areas in Nevada and Utah: U.S. Scientific Investigations Report 2007-5261, p. 43-68, http://pubs.usgs.gov/sir/2007/5261/.

Larson, L.W. and E.L. Peck, 1974, Accuracy of precipitation measurements for hydrologic modeling: Water Resources Research, v. 10 , no. 4, p. 857-863.

Lee, C.H., 1912, An intensive study of the water resources of a part of Owens Valley, California: U.S. Geological Survey Water-Supply Paper 294, 135 p.

Leuning, R., van Gorsel, E., Massman, W.J., and Isaac, P.R., 2012, Reflections on the surface energy imbalance problem: Agricultural and Forest Meteorology, v. 156, p. 65-74.

Masbruch, M.D., Heilweil, V.M., Buto, S.G., Brooks, L.E., Susong, D.D., Flint, A.L., Flint, L.E., and Garden, P.M., 2011, Estimated groundwater budgets, in Heilweil, V.M. and Brooks, L.E., ed., 2011, Conceptual model of the Great Basin carbonate and alluvial aquifer system: U.S. Geological Survey Scientific Investigations Report 2010-5193, p. 73-125, http://pubs.usgs.gov/sir/2010/5193/.

Massman, W.J., 2000, A simple method for estimating frequency response corrections for eddy covariance systems: Agricultural and Forest Meteorology, v. 104, no. 3, p. 185-198.

Maxey, G.B., and Eakin, T.E., 1949, Ground water in White River Valley, White Pine, Nye, and Lander Counties, Nevada: Nevada State Engineer, Water Resources Bulletin 8, $59 \mathrm{p}$.

Moore, C.J., 1986, Frequency response corrections for eddy correlation systems: Boundary-Layer Meteorology, v. 37, nos. 1-2, p. 17-35.

Moreo, M.T., and Swancar, A., 2013, Evaporation from Lake Mead, Nevada and Arizona, March 2010 through February 2012: U.S. Geological Survey Scientific Investigations Report 2013-5229, 40 p., http://dx.doi.org/10.3133/ sir20135229. 
Moreo, M.T., Laczniak, R.J.,and Stannard, D.I., 2007, Evapotranspiration rate estimates of vegetation typical of ground-water discharge areas in the Basin and Range Carbonate-Rock aquifer system, Nevada and Utah, September 2005-August 2006: U.S. Geological Survey Scientific Investigations Report 2007-5078, 36 p., http://pubs.usgs. gov/sir/2007/5078/.

National Centers for Environmental Information (NCEI), National Oceanic and Atmospheric Administration, Department of Commerce, Climate Data Online, http://www.ncdc. noaa.gov/cdo-web/datasets, last accessed April 14, 2014.

Nešpor, V., and Sevruk, B., 1999, Estimation of wind-induced error of rainfall gauge measurements using a numerical simulation: Journal of Atmospheric and Oceanic Technology, v. 16 , no. 4, p. 450-464.

Nevada Administrative Code 445A.455, Revised March 2012, Chapter 445A-Water controls, secondary standards - General requirements: Nevada Administrative Code accessed January 14, 2014, at http://www.leg.state.nv.us/nac/nac445a.html.

Nevada Division of Water Resources, Spring and Streamflow Database, http://water.nv.gov/data/streamflow/, accessed June 12, 2013.

Nevada Revised Statutes, Underground water and well, Nevada State Engineer, Chapter 534.120.

Nichols, W.D., 2000, Regional groundwater evapotranspiration and ground-water budgets, Great Basin, Nevada: U.S. Geological Survey Professional Paper 1628, 82 p., http://pubs.er.usgs.gov/publication/pp1628.

Palmer, C.D., and Cherry, J.A., 1984, Geochemical evolution of groundwater in sequences of sedimentary rocks: Journal of Hydrology, v. 75, p. 27-65.

Priestley, C.H.B., and Taylor, R.J., 1972, On the assessment of surface heat flux and evaporation using large-scale parameters: Monthly Weather Review, v. 100, p. 81-92.

PRISM Climate Group, Oregon State University, http://prism. oregonstate.edu, last accessed December, 2014.

Prudic, D.E., Harrill, J.R., and Burbey, T.J., 1995, Conceptual evaluation of regional ground-water flow in the Carbonate-Rock Province of the Great Basin, Nevada, Utah, and adjacent states: U.S. Geological Survey Professional Paper 1409-d, 102 p., http://pubs.er.usgs.gov/publication/ pp1409D.

Qi, J., Chehbouni, A., Huete, A.R., Kerr, Y.H., and Sorooshian, S., 1994, A modified soil adjusted vegetation index: Remote Sensing of Environment, v. 48, no. 2, p. 119-126.

Roberts, R. J., Montgomery, K. M., and Lehner, R. E., 1967, Geology and mineral resources of Eureka County, Nevada: Nevada Bureau of Mines and Geology Bulletin 64, 152 p.
Rouse, J.W., Haas, R.H., Schell, J.A., and Deering, D.W., 1974, Monitoring vegetation systems in the great plains with ERTS: Proceedings of the third Earth Resources Technology Satellite-1 Symposium: Washington D.C., NASA, Scientific and Technical Information Office, p. 309-317.

Rush, F.E., and Everett, D.E., 1964, Ground-water appraisal of Monitor, Antelope, and Kobeh Valleys, Nevada: Nevada Department of Conservation and Natural Resources, Ground-Water Resources Reconnaissance Report 30, 45 p.

Rush, F.E., and Everett, D.E., 1966, Water-resources appraisal of Little Fish Lake, Hot Creek, and Little Smokey Valleys, Nevada: Nevada Department of Conservation and Natural Resources, Ground-Water Resources Reconnaissance Report $38,38 \mathrm{p}$.

Schuepp, P.H., Leclerc, M.Y., Macpherson, J.I., and Desjardins, R.L., 1990, Footprint prediction of scalar fluxes from analytical solutions of the diffusion equation: BoundaryLayer Meteorology, v. 50, p. 355-373.

Shoemaker, W.B., Lopez, C.D., and Duever, M.J., 2011, Evapotranspiration over spatially extensive plant communities in the Big Cypress National Preserve, southern Florida, 2007-10: U.S. Geological Survey Scientific Investigations Report 2011-5212, 46 p., http://pubs.usgs.gov/ sir/2011/5212/.

Shuttleworth, J.W., 1993, Evaporation, in Maidment, D.R., ed., Handbook of hydrology: New Your, McGraw-Hill, Inc., p. 4.1-4.53.

Smith, J.L., Laczniak, R.J., Moreo, M.T., and Welborn, T.L., 2007, Mapping evapotranspiration units in the Basin and Range carbonate-rock aquifer system, White Pine County, Nevada, and adjacent areas in Nevada and Utah: U.S. Geological Survey Scientific Investigations Report 2007-5087, 20 p., http://pubs.usgs.gov/sir/2007/5087/.

Smith, R.L., 1974, Ecology and field biology (2nd ed.): New York, Harper and Row.

Stull, R.B., 1988, An introduction to boundary layer meteorology: Kluwer Academic Publishers, The Netherlands, 666 p.

Swinbank, W.C., 1951, The measurement of vertical transfer of heat and water vapor by eddies in the lower atmosphere: Journal of Meteorology, v. 8, p. 135-145.

Tanner, B.D., and Greene, J.P., 1989, Estimate of sensible heat and water-vapor fluxes using eddy-correlation methodsFinal report: Prepared for U.S. Army Dugway Proving Grounds: U.S. Army, Dugway, Utah, 17 p.

Theis, C.V., 1940, The source of water derived from wells: Civil Engineering, v. 10, no. 5, p. 277-280. 
Thomas, J.M., Welch, A.H., and Dettinger, M.D., 1996, Geochemistry and isotope hydrology of representative aquifers in the Great Basin region of Nevada, Utah, and adjacent States, U.S. Geological Survey Professional Paper 1409-C, 100 p., https://pubs.er.usgs.gov/publication/pp1409C.

Tumbusch, M.L., and Plume, R.W., 2006, Hydrogeologic framework and ground water in basin-fill deposits of the Diamond Valley flow system, Central Nevada: U.S. Geological Survey Scientific Investigation Report 2006-5249, 38 p., http://pubs.usgs.gov/sir/2006/5249/.

U.S. Census Bureau, 2015a, State and County Quickfacts, last accessed April 14, 2015, at http://www.census.gov/quickfacts/.

U.S. Census Bureau, 2015b, 2010 Population finder, last accessed April 14, 2015, at http://factfinder.census.gov/faces/ nav/jsf/pages/index.xhtml\#.

U.S. Environmental Protection Agency, 2009, National primary drinking water regulations: U.S. Environmental Protection Agency, document EPA 816-F-09-0004, 6 p., accessed February 16, 2012, at http://water.epa.gov/drink/contaminants/ upload/mcl-2.pdf.

U.S. Geological Survey, 2012a, Landsat-A global land-imaging mission: U.S. Geological Survey Fact Sheet 2012-3072, 4 p., http://pubs.usgs.gov/fs/2012/3072/.

U.S. Geological Survey, 2012b, Landsat ecosystem disturbance adaptive processing system (LEDAPS) - Algorithm description document, version 1.3: U.S. Geological Survey, 20 p., accessed December 10, 2013, at http://landsat.usgs.gov/documents/ledaps_add.pdf.
Webb, E.K., Pearman, G.I., and Leuning, R., 1980, Correction of flux measurements for density effects due to heat and water vapour transfer: Quarterly Journal of the Royal Meteorological Society, v. 106, p. 85-100.

Western Region Climate Center, 2015, Cooperative climatological data summaries for Nevada, last accessed April 14, 2015, at http://www.wrcc.dri.edu/summary/Climsmnv.html.

White, W.N., 1932, A method of estimating ground-water supplies based on discharge by plants and evaporation from soil-results of investigations in Escalante Valley, Utah, in Contributions to the hydrology of the United States, 1932: U.S. Geological Survey Water Supply Paper 659, p. 1-105, http://pubs.er.usgs.gov/publication/wsp659A.

Yang, D., Goodison, B.E., Metcalfe, J.R., Golubev, V.S., Bates, R., Pangburn, T., and Hanson, C.L., 1996, Accuracy of NWS 8 " standard nonrecording precipitation gauge - Results and application of WMO intercomparison: Journal of Atmospheric and Oceanic Technology, v. 15, p. 54-68.

Young, A.A., and Blaney, H.F., 1942, Use of water by native vegetation: California Department of Public Works, Division of Water Resources Bulletin 50, 154 p. 


\section{Appendix 1: Description of Spatial Datasets}

The U.S. Geological Survey (USGS) Water Resources Mission Area (WMA) maintains a clearinghouse for publicly available geographic information system (GIS) data on the USGS WMA National Spatial Data Infrastructure (NSDI) node. The NSDI is a physical, organizational, and virtual network designed to enable the development and sharing of digital geographic information resources (Federal Geographic

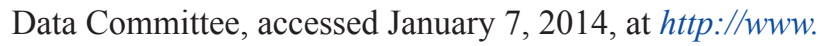
$f g d c . g o v /)$. The GIS datasets created in conjunction with this study have been placed on the WMA NSDI node for public access. Brief descriptions of the datasets are included in this appendix. Complete dataset descriptions, including source documentation and processing steps, can be accessed in the metadata documents accompanying the datasets on the WMA NSDI node. The datasets are in GIS format and require specialized software to view.

\section{Water-Level Altitude Contours for the Diamond Valley Flow System, Central Nevada, 2012}

This dataset represents 2012 water levels in the Diamond Valley Flow System (DVFS) depicted on plate 1 of the report associated with this appendix. Water-level contours were developed using data from wells primarily measured in 2012, although earlier water-level data in select wells were used in cases where no new data were available and water levels were not expected to have changed over time. Detailed information about the sites used to construct these contours is available in the main body of the associated report. The dataset can be downloaded from the WMA NSDI node at $h t t p: / / d x$.doi. org/10.5066/F71J97VZ.

\section{Irrigated Agricultural Lands and Associated Land Disturbance in the Diamond Valley Flow System, Central Nevada, 2011}

This dataset represents agricultural lands assumed to be irrigated in 2011 and associated land disturbances in the DVFS. The data are depicted on plate 1 of the report associated with this appendix. The locations of probable irrigated agricultural lands were interpreted using Landsat imagery from the summer of 2011, National Agricultural Imagery Program imagery from 2010, and well-water use information from the U.S. Geological Survey National Water Information System. Some areas classified as agricultural lands could be irrigated using diverted surface water or springs. Associated disturbances are areas surrounding agricultural lands that might not be irrigated, but have been disturbed as a result of agricultural or other anthropogenic activities. The dataset can be downloaded from the WMA NSDI node at $h t t p: / / d x$.doi. org/10.5066/F7JM27QV.

\section{Groundwater Discharge Area for the Diamond Valley Flow System, Central Nevada}

This dataset represents the groundwater discharge area (GDA) in the DVFS. The GDA depicts the general boundary of groundwater discharge by evapotranspiration (ET) from phreatophytic plants and moist bare soil. Vegetated areas in the GDA are composed of phreatophytic shrubs with smaller areas of grassland, marshland, xeric vegetation, bare soil, and agricultural lands, where phreatophytic shrubs were present historically. Vegetated areas outside the GDA primarily are composed of xeric vegetation and bare soil, although very sparse phreatophytic shrubs could be present on the outer margins of the boundary. The GDA was mapped in the summer of 2011 using field reconnaissance and supporting digital data. Additional supporting field data were gathered in the fall of 2014. The dataset can be downloaded from the WMA NSDI node at $h t t p: / / d x$.doi.org/10.5066/F75B00K7.

\section{Summer Mean Enhanced Vegetation Index for the Diamond Valley Flow System Groundwater Discharge Area, 2010}

This dataset represents the mean Enhanced Vegetation Index (EVI; Huete, 1999) of two Landsat 5 Thematic Mapper scenes from the summer of 2010 in the DVFS. The EVI is a type of vegetation index that uses a canopy background adjustment factor to reduce the influence of soil and background reflectance on the index to increase the signal from healthy vegetation in the image. The EVI includes an additional correction in the calculation to reduce the effect of atmospheric aerosols on the index. The data were used to evaluate and estimate groundwater discharge by ET by relating the mean of EVI calculated from July 24 and August 25, 2010, Landsat scenes to ET measured at four eddy-covariance sites in areas of phreatophytic vegetation of varying types and densities in Kobeh Valley, Nevada. Values of ET were extrapolated for all valleys in the study area using the relation developed for Kobeh valley. The dataset can be downloaded from the WMA NSDI node at $h t t p: / / d x$.doi.org/10.5066/F7930R9K.

\section{Evapotranspiration Units for the Diamond Valley Flow System, Central Nevada, 2010}

This dataset represents ET units derived from the mean EVI calculated from two Landsat 5 Thematic Mapper scenes from the summer of 2010 in the DVFS. The ET units were defined in the DVFS GDA to group areas characterized by similar phreatophytic vegetation type and cover and to extrapolate site-scale groundwater ET estimates across the study area. This dataset represents three ET units: shrubland, grassland, and playa. The grassland ET unit is composed of 
grassland, meadow, and marshland vegetation types. The ET units were developed using a combination of field reconnaissance, EVI and site-scale discharge measurements. The data were used to evaluate and estimate groundwater discharge by ET in the study area. The dataset can be downloaded from the WMA NSDI node at http://dx.doi.org/10.5066/F7DV1HOJ.

\section{References Cited}

Huete, A., Justice, C., and van Leeuwen, W., 1999, MODIS Vegetation Index (MOD 13), Version 3, Algorithm theoretical basis document, http://modis.gsfc.nasa.gov/data/atbd/ atbd_mod13.pdf. 


\section{Appendix 2: Water-Quality Data}

\section{Quality Assurance}

Water-chemistry sampling followed U.S. Geological Survey (USGS) National Field Manual methods (U.S. Geological Survey, variously dated). Samples analyzed for major ions and trace metals were sent to the USGS National Water Quality Laboratory in Denver, Colorado. Samples analyzed for stable isotopes were sent to the USGS Isotope Laboratory in Reston, Virginia.

A field blank was run during the 2012 sampling event for quality-assurance purposes. This quality-assurance sample was used to ensure that sampling equipment (pumps, sampling lines, and bottles) and actions used to collect, process, and analyze environmental samples did not contaminate environmental samples. Results indicated that concentrations of all constituents used in this study's water quality analyses were at or below laboratory detection limits. Internal components of the pump are made of stainless steel, which can corrode and release trace metals (Wilde, 2004), even after diligent decontamination. Although no corrosion was observed on the pump, concentrations of several major ions (calcium, sodium, chloride, magnesium, silica, and manganese) measured in the field blank were at concentrations above laboratory reporting limits. These major-ion concentrations were within 3 percent of those concentrations in environmental samples; therefore, this level of contamination relative to the environmental concentrations indicates no substantial effect was imparted on data interpretations.

A sequential replicate (U.S. Geological Survey, 2006) sample was collected from site 126 in 2012 to quantify variability associated with the collection and processing of a sample. Replicate and environmental-sample concentrations were generally similar (coefficient of variation less than 5 percent), with the exception of aluminum (coefficient of variation 27 percent), where the environmental and replicate concentrations were 4.5 and 6.6 micrograms per liter, respectively (table 6 in the report associated with this appendix).

\section{References Cited}

U.S. Geological Survey, variously dated, National field manual for the collection of water-quality data: U.S. Geological Survey Techniques of Water-Resources Investigations, book 9, chaps. A1-A9, available online at http://water.usgs.gov/ owq/FieldManual.

U.S. Geological Survey, 2006, Collection of water samples (ver. 2.0): U.S. Geological Survey Techniques of WaterResources Investigations, book 9, chap. A4, September 2006, accessed February 3, 2014, at http://pubs.water.usgs. gov/twri9A4/.
Wilde, F.D., ed., 2004, Cleaning of equipment for water sampling (ver. 2.0): U.S. Geological Survey Techniques of Water-Resources Investigations, book 9, chap. A3, accessed October 22, 2009, at http://pubs.water.usgs.gov/twri9A3/. 
For additional information, contact:

Director, Nevada Water Science Center

U.S. Geological Survey

2730 N. Deer Run Rd.

Carson City, NV 89701

http://nevada.usgs.gov/water/ 



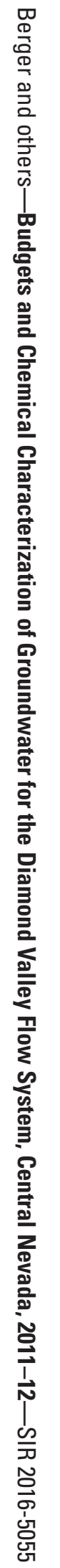

